Florida International University FIU Digital Commons

FIU Electronic Theses and Dissertations

University Graduate School

$11-8-2013$

\title{
Escaping the Resource Curse: The Sources of Institutional Quality in Botswana
}

Angela Gapa

Florida International University, angelagapa@gmail.com

DOI: $10.25148 /$ etd.FI13120605

Follow this and additional works at: https://digitalcommons.fiu.edu/etd

Part of the African Studies Commons, Comparative Politics Commons, International Relations Commons, and the Other International and Area Studies Commons

\section{Recommended Citation}

Gapa, Angela, "Escaping the Resource Curse: The Sources of Institutional Quality in Botswana" (2013). FIU Electronic Theses and Dissertations. 1019.

https://digitalcommons.fiu.edu/etd/1019

This work is brought to you for free and open access by the University Graduate School at FIU Digital Commons. It has been accepted for inclusion in FIU Electronic Theses and Dissertations by an authorized administrator of FIU Digital Commons. For more information, please contact dcc@fiu.edu. 


\section{FLORIDA INTERNATIONAL UNIVERSITY}

Miami, Florida

ESCAPING THE RESOURCE CURSE:

THE SOURCES OF INSTITUTIONAL QUALITY IN BOTSWANA

A dissertation submitted in partial fulfillment of the

requirements for the degree of

DOCTOR OF PHILOSOPHY

in

INTERNATIONAL RELATIONS

by

Angela Gapa

2013 


\section{To: Dean Kenneth Furton}

College of Arts and Sciences

This dissertation, written by Angela Gapa, and entitled Escaping the Resource Curse: The Sources of Institutional Quality in Botswana, having been approved in respect to style and intellectual content, is referred to you for judgment.

We have read this dissertation and recommend that it be approved.

Felix Martin

Shlomi Dinar

Caroline Faria

John F. Clark, Major Professor

Date of Defense: November 8, 2013

The dissertation of Angela Gapa is approved.

$\begin{array}{r}\begin{array}{r}\text { Dean Kenneth Furton } \\ \text { College of Arts and Sciences }\end{array} \\ \hline \begin{array}{r}\text { Dean Lakshmi Reddi } \\ \text { University Graduate School }\end{array}\end{array}$

Florida International University, 2013 
C Copyright 2013 by Angela Gapa All rights reserved. 


\section{ACKNOWLEDGMENTS}

I would like to first and foremost thank my parents, Pheneas and Otilia Gapa for believing in me and for always supporting my dreams, no matter the sacrifice. Thank you to my siblings: Cherub, Tatenda and Tadiwanashe, for your love and support.

I would like to especially thank my dissertation advisor, Dr. John F. Clark, for your insights, your wisdom, your support, your encouragement and your friendship. Special Thanks:

To my committee members, Dr. Felix Martin, Dr. Shlomi Dinar and Dr. Caroline Faria for all your critiques your insights, your time, and your commitment.

To the Department of Politics and International relations for being my home for the last six years.

To the University Graduate School for awarding me the Dissertation Acquisition Fellowship which enabled me to travel to Gaborone, Botswana.

To Dr. Jean Rahier and AADS for travel funding to Botswana.

To Dr. Thomas Breslin for your support, to Dr. Paul Kowert, Dr. Harry Gould and Dr. Ronald Cox for organizational support.

To Michelle Real, Martha Rodriguez and Kimberly Noy for administrative support.

To the Office of the President of the Republic of Botswana for offering me permission to study their beautiful country.

To the faculty and staff of the Department of Political and Administrative Studies at the University of Botswana for hosting me while dong my research.

To the staff at the University of Botswana Library. 
To the Ministry of Foreign and International Affairs, Ministry of Trade and Industry, Ministry of Minerals, Energy and Water Resources and the Ministry of Finance and Development Planning.

To the House of Chiefs (Ntlo ya DiKgosi)

To the CEO and staff of De Beers Botswana.

To the CEO and staff of Debswana.

To the leaders and members of the Botswana Democratic Party, Botswana National Front and Botswana Congress Party for allowing me to interview you.

To Dr. Lydia Nyati-Saleshando for patiently and promptly responding to all my emails.

To all my friends and family. I cannot name you all, but you all know this was more than just an academic endeavor for me. It was a spiritual journey as well. And I would not have accomplished it without your help.

And to God, who makes all things possible. 


\section{DEDICATION}

To my Parents,

Pheneas and Otilia Gapa,

For entrusting me with your legacy.

I hereby pass it on

With love 


\title{
ABSTRACT OF THE DISSERTATION
}

\section{ESCAPING THE RESOURCE CURSE: THE SOURCES OF INSTITUTIONAL QUALITY IN BOTSWANA}

\author{
by \\ Angela Gapa \\ Florida International University, 2013 \\ Miami, Florida

\section{Professor John F. Clark, Major Professor}

Botswana has recently garnered analytic attention as an anomaly of the "resource curse" phenomenon. Worldwide, countries whose economies are highly skewed towards a dependence on the export of non-renewable natural resources such as oil, diamonds and uranium, have been among the most troubled, authoritarian, poverty-stricken and conflict-prone; a phenomenon widely regarded as the "resource curse". The resource curse explains the varying fortunes of countries based on their resource wealth, with resource-rich countries faring much worse than their resource-poor counterparts. However, Botswana, with diamond exports accounting for 50percent of government revenues and 80percent of total exports, has achieved one of the fastest economic growth rates in the developing world in the last 50 years. Furthermore, the Freedom House ranks it as the safest, most stable, least corrupt and most democratic country on sub-Saharan Africa.

In attempting to answer why Botswana apparently escaped the "resource curse", this research assumes that both formal and informal institutions within the state acted as intermediary variables in determining its fortune. This research thus addresses the deeper 
question of where Botswana obtained its unique institutional quality that facilitated its apparent escape of the resource curse. It traces Botswana's history through four lenses: legitimacy and historical continuity, political culture, ethnicity and identity management, and external relations; as having explanatory value in understanding the Botswana exception.

The research finds most evidence of Botswana's institutional quality emanating from the country's political culture which it found more compatible with the institutions of development and democracy that facilitate both positive economic and political outcomes. It also found evidence of legitimacy and historical continuity facilitating the robustness of both formal and informal institutions in Botswana, and identity management through assimilation as having buffered against the effects of ethnically motivated resource plunder. It however, found the least support for the assertion that external relations contributed to institutional quality. 


\section{TABLE OF CONTENTS}

CHAPTER

PAGE

CHAPTER ONE:

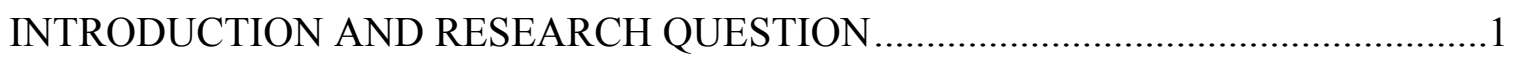

The Case of Botswana: Escaping the Resource Curse .................................................... 5

Hypotheses and Overview of Remaining Chapters ...................................................... 9

Research Design, Methods and Data Collection Techniques …………………............ 15

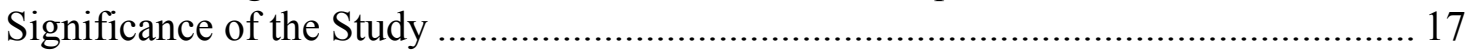

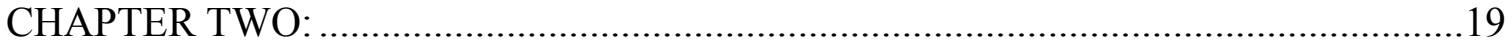

LITERATURE REVIEW AND CONCEPTUAL FRAMEWORK …............................19

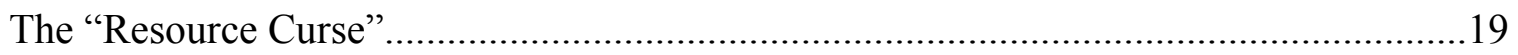

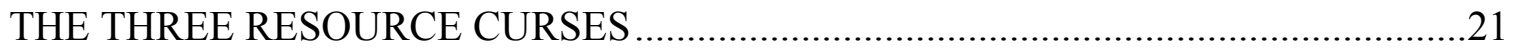

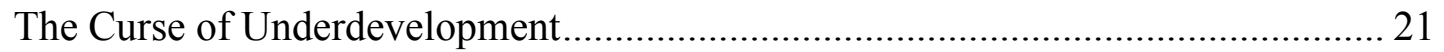

The Curse of Authoritarianism ............................................................................... 28

The Curse of Violent Conflict .................................................................................... 33

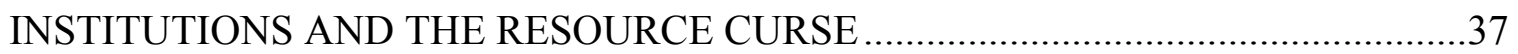

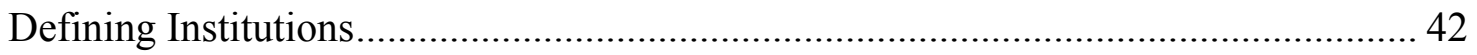

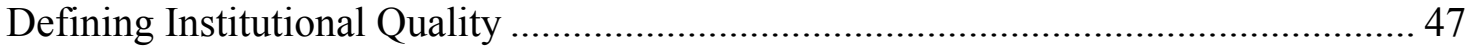

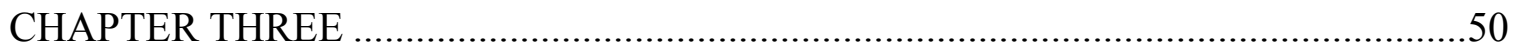

LEGITIMACY AND INSTITUTIONAL CONTINUITY IN BOTSWANA ...................50

Chapter's Theoretical Framework: The Concept of Legitimacy ................................... 52

CONTINUITY AND THE FOUNDATIONS OF LEGITIMACY IN BOTSWANA ......56

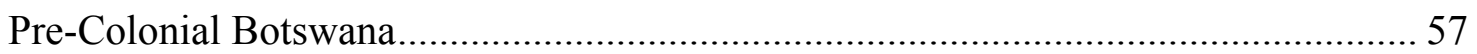

Early Political Organization ……………………….......................................... 57

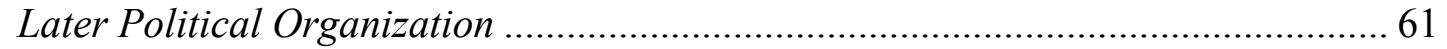

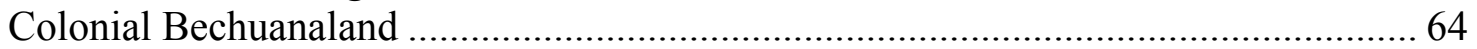

Independence and Post-Colonial Botswana ............................................................... 71

Background to Independence ............................................................................ 71

Institutional Continuity in Post-Colonial Botswana …………………..................... 74

SOURCES OF LEGITIMACY IN BOTSWANA ……........................................... 77

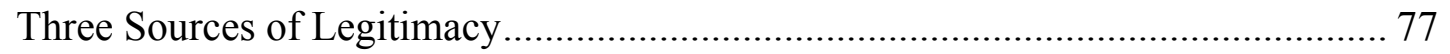

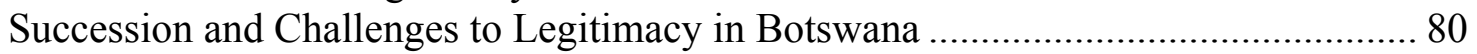

Explaining BDP's Longevity as Legitimacy......................................................... 83

Insights on the Legitimacy of Authority in Botswana ................................................... 86

LEGITIMACY AND CONTINUITY IN COMPARATIVE PERSPECTIVE ..................96

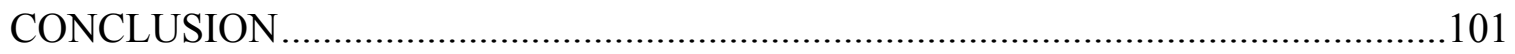

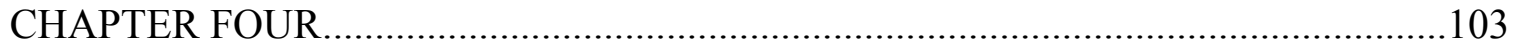

POLITICAL CULTURE AND INSTITUTIONAL QUALITY IN BOTSWANA..........103

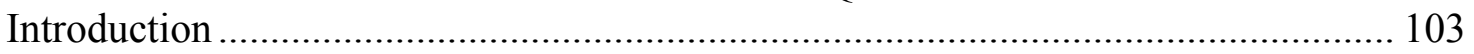

The Concept of Political Culture............................................................................... 105 
POLITICAL CULTURE IN BOTSWANA...............................................................112

The Traditional Foundations of Political Culture in Botswana.................................... 112

Botswana's Elite Political Culture ……………………........................................... 121

Political Culture in Botswana: Traditional vs. Secular ................................................ 124

Mass Political Culture in Botswana ........................................................................ 126

Botswana's Mass Political Culture described...................................................... 126

Afrobarometer Reflections of Mass Political Culture in Botswana ........................ 128

The Meaning of Democracy in Botswana .......................................................... 130

The Support for Democracy and Rejection of Alternatives in Botswana ............... 132

Views on Democratic Institutions in Botswana ................................................... 134

Botswana Political Culture in Comparative Perspective ................................................137

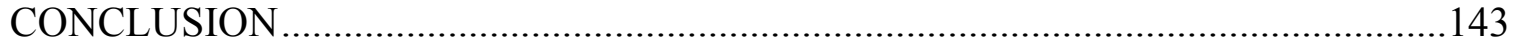

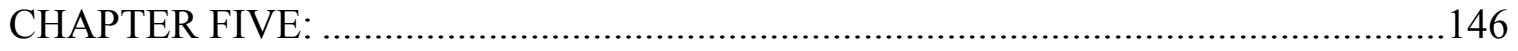

ETHNICITY AND IDENTITY MANAGEMENT AS A SOURCE OF

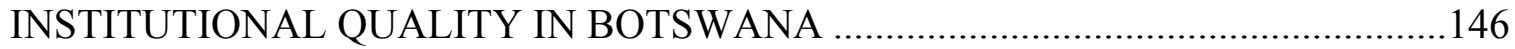

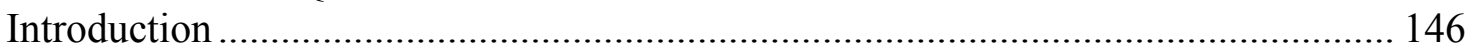

CONCEPTUAL FRAMEWORK OF ARGUMENT ……….......................................149

Ethnicity and Identity: Definitions and Perspectives ................................................ 149

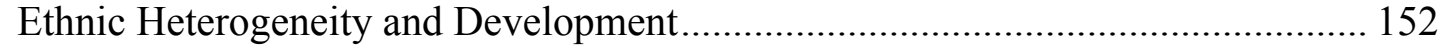

Ethnicity and Resource Conflict....................................................................... 154

ETHNICITY AND IDENTITY MANAGEMENT IN BOTSWANA …….....................161

Ethnicity and Identity Groups in Botswana: Description............................................ 161

Historical Ethnic Relations in Botswana: Pre-Colonial ........................................... 165

The Transformation of Botswana Ethnic Identities and Attitudes during Colonialism

Assimilation and Identity Management in Post-Colonial Botswana ......................... 176

Conceptual Framework of Assimilation............................................................... 176

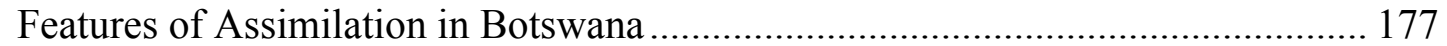

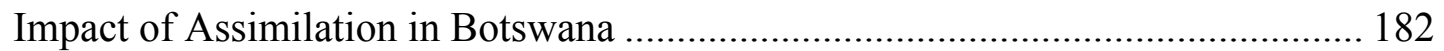

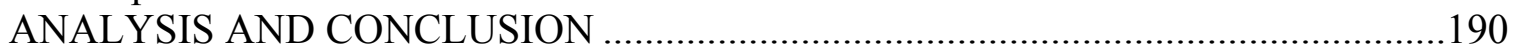

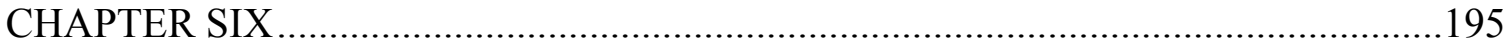

THE EXOGENOUS SOURCES OF INSTITUTIONAL QUALITY IN BOTSWANA 195

Exogenous Sources of Institutional Quality: An Introduction ................................... 195

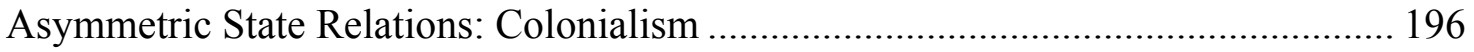

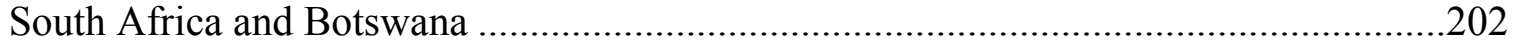

Regional Hegemony's Impact on Institutional Development ..................................... 202

Pre-1966 Botswana - South Africa Relations ........................................................ 204

The South African Customs Union (SACU) and early Botswana/SA relations...... 209

Apartheid South Africa's Relations with Independent Botswana............................... 215

Botswana-South Africa Relations and Domestic Developments in Botswana ........... 218

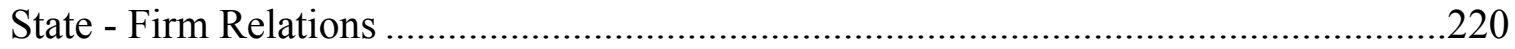

THE ROLE OF DE BEERS IN BOTSWANA'S DEVELOPMENT ………................22

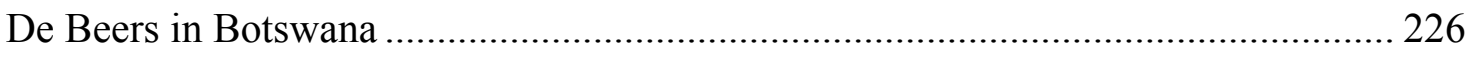


De Beers' Impact on Economic Development in Botswana .................................... 230

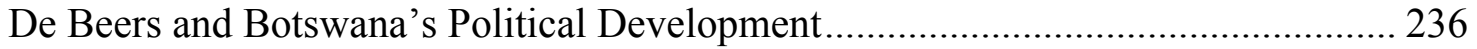

De Beers and Political Party Financing in Botswana .............................................. 236

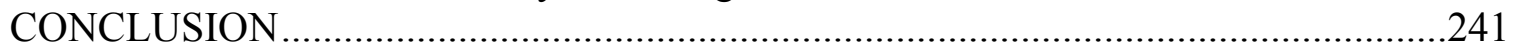

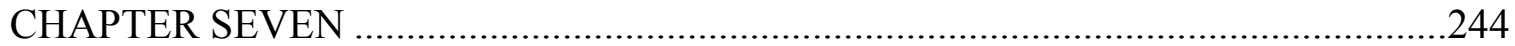

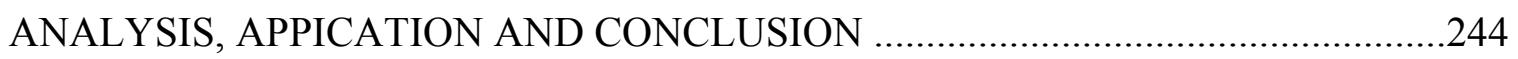

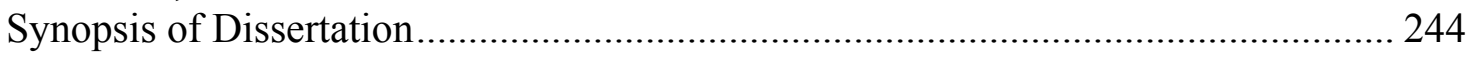

Botswana's Legislative Oversight in the Diamond Industry: A Comparative Analysis

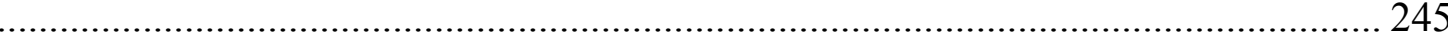

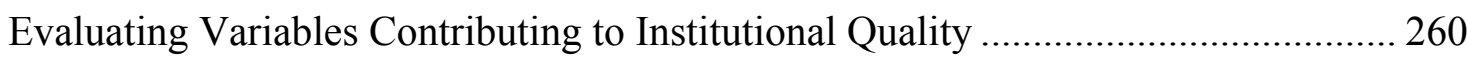

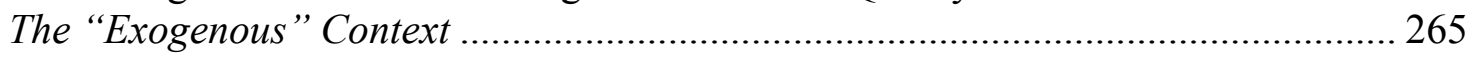

Endogenous Sources of Institutional Quality in Botswana ...................................... 268

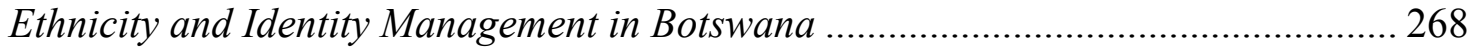

Legitimacy and Historical Continuity in Botswana ............................................... 271

Political Culture and Institutional Quality in Botswana ....................................... 275

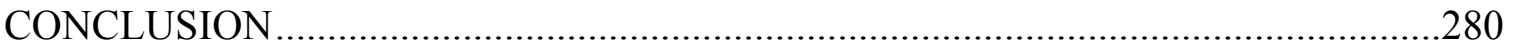

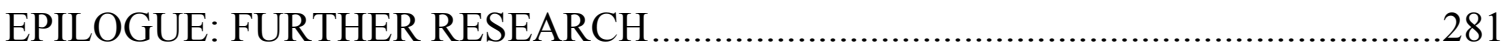

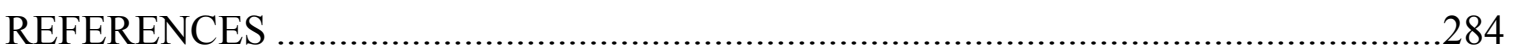

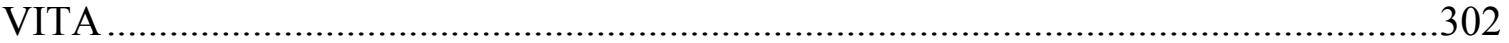




\section{LIST OF TABLES}

$\begin{array}{ll}\text { TABLE } & \text { PAGE }\end{array}$

$2.1 \quad$ Hierarchy of Institutions 46

5.1 Tswana Tribes, Bantu (The recognized tribes) 161

5.2 Marginalized Bantu Identity Groups 162

5.3 Marginalized Khoisan (BaSarwa) 163

$\begin{array}{lll}5.4 & \text { Botswana Tribes and Totems } & 169\end{array}$ 


\section{LIST OF FIGURES}

FIGURE $\quad$ PAGE

2.1 The Eight Characteristics of Institutional Quality 48

3.1 Rural Population \% of Total Population in Botswana (1967 to 2013) 91

4.1 The Meaning of Democracy in Botswana 131

4.2 The Support of Democracy in Botswana 134

4.3 Views of Democratic institutions in Botswana 135

4.4 Freedom of Political Participation in Botswana 136

4.5 Trust in the Institutions of the Presidency in Nigeria versus Botswana 139

4.6 Percentage of Respondents who paid bribes to government officials $\quad 140$

5.1 Causes of Ethnic Conflict 156

5.2 Causes of Ethnic conflict: Theoretical Elements 157

6.1 World Diamond Productions (2011) 227

6.2 Botswana Trend in GDP per capita (1980-2010) 233

6.3 The Decline in the De Beers Market Share 235 


\section{ABBREVIATIONS AND ACRONYMS}

AGOA African Growth and Opportunity Act

AIDS Acquired Immune Deficiency Syndrome

ANC African National Congress

ARV Anti-Retroviral Drug

AU African Union

BCL Bamangwato Concessions Limited

BCP Botswana Congress Party

BDF Botswana Defense Force

BDP Botswana Democratic Party

BDVC Botswana Diamond Valuing Company

BEDIA Botswana Export Development and Investment Authority

BIDPA Botswana Institute for Development Policy Analysis

BIP Botswana Independence Party

BLS Botswana Lesotho Swaziland

BLNS Botswana Lesotho Namibia Swaziland

BMC Botswana Marketing Board

BNF Botswana National Front

BP Bechuanaland Protectorate

BSB Botswana Savings Bank

CEO Chief Executive Officer

CIA Central Intelligence Agency

CKGR Central Kalahari Game Reserve

CSO Central Statistical Office 


\begin{tabular}{|c|c|}
\hline DRC & Democratic Republic of Congo \\
\hline DTC & Diamond Trading Company \\
\hline DTCB & Diamond Trading Company Botswana \\
\hline $\mathrm{EU}$ & European Union \\
\hline FDI & Foreign Direct Investment \\
\hline FLEC & Front for the Liberation of the Enclave of Cabinda \\
\hline GDP & Gross Domestic Product \\
\hline $\mathrm{HCT}$ & High Commission Territories \\
\hline HDI & Human Development Index \\
\hline HIV & Human Immuno-Deficiency Virus \\
\hline MK & Umkontho weSizwe \\
\hline MNC & Multinational Corporation \\
\hline MOFAIC & Ministry of Foreign Affairs and International Cooperation \\
\hline MPLA & People's Movement for the Liberation of Angola \\
\hline OAU & Organization of African Unity \\
\hline SACU & Southern African Custom Union \\
\hline SADC & Southern African Development Community \\
\hline SSKA & Sir Seretse Khama Airport \\
\hline UNDP & United Nations Development Programme \\
\hline UNESCAP & $\begin{array}{l}\text { United Nations Economic and Social Commission for Asia and the } \\
\text { Pacific }\end{array}$ \\
\hline UNITA & $\begin{array}{l}\text { União Nacional para a Independência Total de Angola } \\
\text { (National Union for the Total Independence of Angola) }\end{array}$ \\
\hline WTO & World Trade Organization \\
\hline
\end{tabular}




\section{CHAPTER ONE:}

\section{INTRODUCTION AND RESEARCH QUESTION}

The country of Botswana has recently garnered critical acclaim as one of subSaharan Africa's few developmental success stories. Being among the poorest countries in the world at the time of its independence from the British in 1966, the country managed to achieve and maintain the highest sustained rate of growth in Gross Domestic Product (GDP) ${ }^{1}$ in the world, an average of 6 percent between 1966 and 2000. By the year 2010, its annual per capita GDP of US\$13,100 was well above the sub-Saharan African average (CIA, 2010). In addition, the country has been hailed as the best credit risk on the continent (Heritage Foundation, 2009). Botswana is a small country in southern Africa, bordered to the south by South Africa, to the northwest by Namibia and to the northeast by Zimbabwe. Despite being demographically challenged with a population of just above 2 million, and geographically challenged: the arid country is entirely landlocked; Botswana has fared well on indicators of human development. The United Nations Development Program (UNDP) estimated an increase in the Human Development Index ${ }^{2}$ from 0.509 in 1975 to 0.649 in 2007. Literacy rates in the country have increased from 34 percent in 1970 to 82 percent in 2007 and infant mortality experienced a drop from 108 per 1000 live births in 1975, to

\footnotetext{
${ }^{1}$ GDP refers to Gross Domestic Product and is measure of the market value of all final goods and services made within the borders of a country in a year. It is often positively correlated with the standard of living of a country and is therefore used as an indicator for economic development.

${ }^{2}$ Human Development Index is an indicator created by the United Nations Development Program to rank the levels of human development using data such as infant mortality, life expectancy, standard of living and education.
} 
58 by 1998 (UNDP, 2007). In addition, the county has been a beacon of peace, democracy and stability in an otherwise volatile part of the world (Samatar, 1997).

Diamond mining has fueled much of Botswana's economic expansion and currently accounts for more than one-third of its GDP. The country obtains about 70-80 percent of its export earnings and about half of the government's revenues from this one resource (CIA, 2010). This fact makes Botswana's developmental record all the more impressive, particularly when compared to the many resource-rich sub-Saharan African countries like Nigeria, Angola and the Democratic Republic of Congo (DRC), for these oil and mineral dependent countries are poorer today than they were at independence. Nigeria has failed on many indicators of economic development and democratic governance. The most populous country in Africa, Nigeria is the premier oil-exporting nation on the continent. However, despite this fortune, the number of Nigerians living under the UN poverty threshold of a dollar a day has risen from 17.1 million in 1980 to 112.47 in $2010^{3}$, despite a development plan at independence to reach the income bracket of developed countries aimed at generating over $\$ 350$ billion by the year 2000 (Shaxson, 2005). In the case of the DRC, revenues from diamonds and coltan have been misused to sponsor violence motivated by greed, which has precipitated into one of Africa's largest multinational wars to date (Kabemba, 2011). Furthermore, the country's HDI has been estimated by the UNDP (2007) to be 0.239 , and the country ranks $168^{\text {th }}$ out of the 169 countries in the database.

Precedent and theory has reaffirmed what has now become well-established as the "resource curse," a pattern that has seen resource-rich countries becoming less

\footnotetext{
${ }^{3}$ http://www.bbc.co.uk/news/world-africa-17015873
} 
wealthy and less competently governed than their resource-poor counterparts. According to Auty (1993), the resource curse refers to the paradox that countries and regions with an abundance of natural resources, specifically point-source nonrenewable resources like minerals such as diamonds and uranium, as well as oil, tend to have less economic growth and worse political development outcomes than countries with fewer natural resources. Botswana's impressive record therefore raises the question: Why did Botswana, a country rich in diamonds, manage to escape the resource curse and achieve exceptional economic success, as well as peace and democracy?

To answer this question, the empirical fact that natural resources are negatively correlated with positive economic growth, has been reconciled with the observation that there have been these varying outcomes across countries. An emerging group of scholars now argue that the effect of resources is not determined by resource endowments alone, but instead hinge upon the quality of a country's institutions. The underlying reason cited in Botswana literature for its economic fortune, is that the country has exercised good economic governance, a factor that is important to any level of economic growth. Atushi Iimi (2006) argues that the reason why Botswana has apparently escaped the resource curse is that the country has sound institutions and good governance. He cites Acemoglu, Johnson and Robinson (2002) who point out that Botswana's good institutions, particularly in the private property area, have stemmed from among other factors, the political leadership's choice of sound policies and the elite's motivation to reinforce strong institutions. When compared to other countries in southern Africa and 
around the world, Botswana fares well on indices that reflect a country's sound institutions ${ }^{4}$.

While it is true that Botswana managed to put in place the right policies and implemented them in order to escape the effects of natural resource endowment, it is unclear why other countries that are resource-rich have failed to achieve the same success as Botswana, despite having similar management and regulatory institutions surrounding the management of resource revenues. This therefore begs the question of why institutions aimed at curbing the resource curse and its effects, worked in Botswana and not in other countries like Nigeria, Angola or Congo. Although there is near consensus that institutions play a key intermediary role in determining the effects of the resource curse, it is unclear why despite having similar institutions; Botswana achieved success while other countries fell victim to the resource curse. Thus, where Botswana obtained its institutional quality from is a key missing link in literature on Botswana, on institutions and fundamentally on the resource curse. As a result, the main goal of this dissertation is to address this gap in the literature and answer the specific question:

\section{How did Botswana succeed in establishing the institutional quality that enabled it to turn its mineral wealth into a developmental asset?}

In other words, what are the sources of Botswana's institutional quality? The goal of this dissertation is to answer this question.

\footnotetext{
${ }^{4}$ See appendices for Botswana's Bertlesmann Transformation Indices.
} 


\section{The Case of Botswana: Escaping the Resource Curse}

Botswana has been hailed as an exception to the resource curse. This is mainly because it is relatively peaceful; there has been no documented incidence of intrastate violent conflict in Botswana to date (Eleazer, 2009) $)^{5}$. Second, it is a nominally democratic country with peaceful political turnover ${ }^{6}$. Third, it has had one of the fastest growing economies in the developing world during the past five decades (Basedau, $2005)^{7}$. All this has occurred despite Botswana's endowment of valuable nonrenewable natural resources as the basis of its wealth.

As mentioned above, the underlying reason cited in Botswana literature for its economic fortune has been that the country has exercised good economic governance, a factor that is important to any country's economic growth. Using Kaufmann, Kraay and Mastruzzi's (2003) data, Iimi (2006:9) shows that Botswana has fared well in indicators such as voice and accountability, political stability, government effectiveness, regulatory quality, rule of law and control of corruption. He argues that Botswana has done well in voice and accountability, which is required for developmental state to reflect civil liberties and political rights. This makes resource extraction transparent and authority will in turn exercise discipline. Second, Botswana fares well in indicators of government effectiveness. Mineral revenue in Botswana is used to support and finance investment expenditures particularly on health and

\footnotetext{
${ }^{5}$ See Appendix I

${ }^{6}$ See Appendix II

${ }^{7}$ See Appendix VI
} 
education. This thus increases the quality of public services and competence of civil servants.

Third, the regulatory quality of Botswana is another reason for its economic development. In Botswana, diamond mining leases are provided for up to 25 years. The Botswana government retains 50 percent of the shares of its joint venture with De Beers: Debswana. The country's Ministry of Minerals, Energy and Water Resources has direct responsibility for natural regulation and management. Rule of law and control of corruption are the fourth and final indicators for success in Botswana. Botswana is currently ranked as the best credit rick country in sub-Saharan Africa (CIA, 2011). In a country where the economy is open, more efficient distribution of resource revenues is possible, leading to growth and development. Iimi (2006) argues that the budgetary process in Botswana is relatively transparent. The constitution of the country gives autonomy to the attorney general's office, making it independent from governmental and political influence (ibid).

These same good policies are the ones which enabled Botswana to become immune to effects of the resource curse such as the "Dutch Disease", the apparent relationship between the increase in exploitation of natural resources and a decline in the manufacturing sector. Amy Poteete (2009) argues that in order to escape the effects of the Dutch Disease, the Botswana government benefitted initially from being a member of the Rand Monetary Area, controlled by the South African government. Only ten years after the discovery of diamonds at Orapa mine did Botswana introduce its own currency, the Pula. With the introduction of the new currency in 1976 came Botswana's vulnerability to the expected appreciation of the currency due to diamond 
exports. However, as Poteete (2009) argues, several mechanisms prevented this outcome. The first mechanism implemented by the Botswana government was the frequent but small adjustments to the currency's nominal exchange rates between 1976 and the late 1990's. Thus during this period, the currency did not float. The government maintained a stable real exchange rate with the South African Rand, Botswana's main import currency, until the late 1990's. Depreciation of the Rand against the US dollar, Botswana's main export currency, prevented the appreciation of the Pula against the US dollar. Thus, Poteete (2009) contends that the relative stability of the Pula vis-a-vis the rand and the sustained depreciation of the pula against the US dollar (and thus it not floating), enabled the country to escape the Dutch disease symptoms that other resource-rich countries face.

During the late 1990's the Pula drastically appreciated against the South African Rand, a phenomenon that coincided with an equally sharp depreciation against the US dollar. Preventing currency fluctuations enabled other tradable goods to maintain competitiveness on world markets and hence encouraged economic diversification, something other resource countries in Africa have failed to do (Sarraf and Jiwanji, 2001). As a result, Botswana gained purchasing power and increased competitiveness in its main import market, South Africa. Poteete (2009) argues that by 2004, following a depreciation of 7.5percent against the US dollar, real exchange rates began to stabilize. In 2005, the Botswana government combined a steep 12.5 percent devaluation with the introduction of a crawling peg in order to decrease the probability of future currency overvaluation, conditions that still persist today (Poteete, 2009). 
Sarraf and Jiwanji (2001) argue that in order to avoid excessive increases in expenditure during boom periods, the Botswana government accumulated international reserves and ran budget surpluses earmarked for stability spending in leaner periods. In doing so, the government avoided drastic cuts to expenditures during bust years and reduced inflationary pressures. Second, they also managed the nominal exchange rate to avoid appreciation of the local currency. This was largely achieved through accumulation of international reserves. In spending its revenues, the Botswana government based its expenditure levels on long-term expectations of export earnings and government revenues. Excess revenue generated was used to build up foreign exchange reserves at the Bank of Botswana, thus providing reserves in times when revenue generation was low. The Botswana government in addition astutely avoided undertaking capital intensive developmental projects where no provisions of long term recurrent costs existed (Sarraf and Jiwanji, 2001). It consistently based its spending on National Development Plans that were voted into force by parliament. Parliamentary approval was always required before the inception of a project and such projects requires provisions for cost recovery. In the face of resource busts, the Botswana government took the precautionary measures of assuming long term crises rather than temporary ones. This was reflected in the experience of the 1981-82 decline in diamond earnings. Faced with uncertainty, the government adopted a package of adjustment policies including limits in lending, increases in the primary lending rates, freezing wages and salaries and devaluing the pula (Sarraf, 2001). This selection of policies was implemented well and yielded the desired results. 
However, economic explanations like the one provided above are insufficient in explaining varying outcomes across countries. In contrast to Botswana, other resource-rich countries like Nigeria have not benefitted as much from the large increases in oil prices as well as technological improvements that come with oil extraction. Nigeria has been marred by years of balance-of- payment problems and debt crises, despite selecting similar legal and regulatory frameworks surrounding the management of its extractive industry as Botswana. Botswana has undoubtedly fared better than its other resource-rich counterparts who are poorer today than they were at the time of their independence. It is therefore not clear why countries like Nigeria, that are resource-rich, failed to achieve the same success that Botswana reached in implementing growth-promoting policies. This study is of the view that the economic and institutional explanations of the resource curse are incomplete, and fail to address the origins and sources of institutional quality, which ultimately determine whether a country will be successful in escaping the resource curse. Using the anomalous experience of Botswana as a case in point, this dissertation attempts to uncover the roots and sources of institutional quality, that are apparently absent in other resource-rich countries.

\section{Hypotheses and Overview of Remaining Chapters}

This dissertation isolated four hypotheses in order to ascertain the sources of institutional quality in Botswana that enabled it to escape from the resource 
curse. These hypotheses are addressed in four substantive chapters in this dissertation.

Chapter 1 presents an introduction to the research problem and states the research question. It describes the Botswana anomaly within the context of the resource curse, and asks the question of why Botswana escaped the resource curse. Chapter 1 also illustrates Botswana's economic and political achievements in comparative perspective to other natural resource exporting countries in Africa. It concludes with an analysis of the significance of this study.

Chapter 2 reviews the literature of the resource curse in depth, and provides a conceptual framework under which to analyze the phenomenon. It provides analyses of the three main resource curses: the curse of economic stagnation, the curse of violent conflict, and the curse of authoritarianism, all empirically observed across resource-rich countries. Chapter 2 analyzes the role of institutions as intervening variables in addressing the resource curse. It provides operational definitions of what institutions are, describes the different types of institutions and explains the concept of most relevance to this dissertation: institutional quality, including its measures.

The next four chapters are divided into two parts. Chapters 3, 4 and 5 address what are referred to as the "endogenous sources of institutional quality in Botswana" and focus on processes that evolved within Botswana at three different periods: pre-colonial, colonial and post-colonial. Chapter 6 addresses the "exogenous sources of institutional quality in Botswana," emphasizing imported sources of institutional quality. 
Chapter 3 addresses the first endogenous source of institutional quality identified in the following hypothesis:

\section{H1a: The legitimacy and historical continuity of Botswana's political}

\section{institutions from pre-colonial, through colonial and into the post-colonial era,} made Tswana institutions legitimate thus fostering institutional strength and quality in resource management.

This hypothesis stems from a rich set of literature that argues that the reason most African countries lack good governance and institutional quality is because their institutions were disrupted by institutions of slavery and colonialism. The basic assumption of the chapter is thus: where pre-colonial institutions were not disrupted, or where they were left untouched from pre-colonial, through colonial and into postcolonial times, there will be high levels of institutional quality and good governance. It therefore looks at the role of institutional continuity in strengthening institutional quality. This research assumes that where institutional continuity exists, particularly in sub- Saharan Africa, it can legitimize the rule of law and the institutions themselves. Political legitimacy is important to political organization as it minimizes the need of a regime to use excessive force or coercion on its citizens. Hence the hypothesis assumes a high level of continuity and legitimacy of political and economic institutions in Botswana that are otherwise absent elsewhere on the continent or in other resource-rich countries.

According to Gilley (2006), a legitimate state is less dominating over its citizens because the legitimate use of power minimizes the negative consequences of power. As a result, the citizens gain a certain level of trust in the system, which does not result in 
grievances brewing within the population. According to Lipset (1983), legitimacy involves the capacity of the political system to engender and maintain the belief that the existing political institutions are the most appropriate ones for the society ${ }^{8}$. Pierre Englebert (2000) defines state legitimacy as “the condition when a state's structures have evolved endogenously to its own society and there is some level of historical continuity to its institutions". State legitimacy is thus a historical, structural condition of the entire state apparatus. The study assumes that most African states lost their legitimacy historically through the adoption of colonial structures and the acceptance of colonial territorial boundaries. However, it also assumes that due to the arbitrary nature of the exercise of colonialism, some countries suffered more disruption than others, Botswana being among the lucky few to escape disruption.

Chapter 4 explores the hypothesis:

H1b: Botswana's distinctive political culture enabled it to build strong enough institutions to help manage its mineral wealth.

This hypothesis suggests that there are aspects of Tswana political culture that enabled it to form strong institutions and aided in the translation of mineral wealth to national wealth. Political culture in this context refers to "the sets of symbols and meanings involved in securing and exercising political power" (Olick and Omeltchenko $(2008,300-01)$. It refers to the attitudes, beliefs and sentiments that offer meaning to political processes. In this sense, political culture also provides the fundamental assumptions and rules that govern behavior in the political system. Political culture embraces the political ideals and operating norms of a polity or 
community, and is the manifestation in aggregate form of the psychological and subjective dimensions of politics. Political culture is a product of a political system's collective history and life histories of members of the system. It is rooted in public events as well as private experience. This dissertation argues that Botswana's peculiar political culture provided the foundation onto which newer institutions could be entrenched.

Chapter 5 addresses the third hypothesis for the research:

\section{H1c: Botswana's high relative level of ethnic homogeneity enabled the}

\section{building of robust institutions and deemed violent conflict over resources based on ethnic grievances infeasible}

One of the most cited sources of the lack of institutional quality in Africa is ethnic fractionalization. Particularly, Easterly and Levine (1997) argue that this reason is what accounts for Africa's economic growth tragedy despite ranking African countries growth potential ahead of East Asia's in the 1960's. They argue that ethnic diversity has led to social polarization and entrenched interest groups in Africa and has thereby increased the likelihood of selecting socially sub-optimal policies. Furthermore, this hypothesis is supported by the notion proposed by Ross (2002) that groups in resource-rich societies form factions to gain access to resources based on ethnic cleavages. According to Gurr (1997) ethno-political conflict occurs when groups define themselves in reference to some combination of common descent, values and cultural traits, as well as shared historical instances on behalf of collective interests against the state or other groups. Therefore, this hypothesis assumes that in the absence of these 
ethnic divisions, violent conflict and institutional deterioration are deterred. It hypothesizes that where the ethnic divisions are not significant enough to form societal cleavages that will encourage rent-seeking behavior or recruitment into rebellions based either on greed or on grievance, the violent resource curse will not occur. It also assumes that ethnically homogenous states have greater institutional quality.

Chapter 6 addresses how forces external to Botswana had an influence (if any) in the selection or shaping of Botswana's economic and political institutions through the following hypothesis:

\section{H2: Botswana's relationship with external actors (such as former} colonizer Britain, regional hegemon South Africa, and invasive multinational De Beers) helped to shape its institutions, due to a perceived interest in functional institutions in Botswana.

This hypothesis suggests that Botswana's institutions reflect the interests of its former colonizer Britain, its hegemonic neighbor South Africa, and its intrusive yet secretive economic partner, De Beers. As a result, it argues that Botswana had an external source of stability through its relations with these three actors since it was in their best interest for Botswana to have institutional quality. I hypothesize that British colonialism put in place institutions for the benefit of Britain. I hypothesize that apartheid South Africa had a vested interest in a non-radical Botswana thus investing in creating a functional Botswana state and establishing control over Botswana's trade globally. I hypothesize that as it was in De Beers' best interest to have a steady supply of diamonds; it buffered Botswana from the vulnerabilities of 
the diamond industry and funded its ruling political party. Whether these assertions are true is what this dissertation aims to uncover.

\section{Research Design, Methods and Data Collection Techniques}

The research utilized the case study design, defined by Yin (1994:13) as "an empirical inquiry that investigates a contemporary phenomenon within its real-life context, especially when the boundaries between phenomenon and context are not clearly evident". The case study design was utilized to deliberately study the contextual conditions of Botswana's sources of institutional quality. As a "deviant case study," (i.e. deviating from the standard generalizations of established theory supporting the "resource curse"), it had comparative aspects to it, and drew counter-perspectives from resourcecursed countries particularly Nigeria, Angola and the Democratic Republic of Congo. It employed the problem-driven approach of analytic eclecticism (Katzenstein and Sil 2008), featuring the extraction, adaptation, and integration of discrete concepts, mechanisms, logical principles, and interpretations from various fields, and thus relied on multiple sources of evidence. These sources of evidence included: key informant interviews conducted in Gaborone, Botswana over a period of five months, statistical data from Afrobarometer, archival data, secondary data and participant observations.

A total of 33 interviews were conducted with experts and key informants who are members of Botswana's academic, political, economic, civil society, traditional, administrative and bureaucratic elites, each very knowledgeable of their particular niche in Botswana society. Among the elites interviewed were economic elites such 
as the Chief Executive Officer of De Beers Botswana; political elites including legislators and members of the leadership of the Botswana Congress Party and the Botswana Democratic Party; traditional elites, including representatives of the House of Chiefs (Ntlo ya Dikgosi); academic elites including professors of political science and administration at the University of Botswana; administrative and bureaucratic elites from the Ministry of Minerals, Energy and Water Resources; Ministry of Foreign Affairs and International Cooperation, Ministry of Trade and Industry, and the Ministry of Finance and Development Planning; as well as civil society elites including the leaders of minority civil rights organizations. These open-ended interviews were conducted primarily to gain expert knowledge on the various variables under scrutiny, but also utilized the narratives that emerged.

The study employed basic statistical analysis of Afrobarometer data as a measure of legitimacy and political culture in Botswana. Afrobarometer is a research project that measures public attitudes on economic, political, and social matters in sub-Saharan Africa, and is based on face-to-face and house-to-house interviews of individuals. It is generally considered to be reliable and generalizable.

In addition, the research utilized participant observation. The immersion into Botswana society as well as the development of rapport among locals, gave the study insight into the political socialization processes present in Botswana, reflecting the country's political culture, legitimacy, identity dynamics and views on external factors. It utilized archival data obtained from the National Archives of Botswana as well as the Botswana section of the library at the University of Botswana. Among the archival data analyzed were masters and doctoral dissertations dating as far back as 
1975, as well as minutes to various symposia conducted in Botswana surrounding the themes of governance and democracy. Finally, the research utilized secondary sources of information including newspaper articles particularly from Mmegi, Sunday Standard, the Voice and the Botswana Gazette. Particularly the research was interested in letters to the editor of a political nature, as well as political discussions on the respective newspapers' facebook pages. This helped to gauge the level of political participation in Botswana, as well as helped identify issues of key importance to ordinary Botswana citizens.

\section{Significance of the Study}

This study extends the understanding of explanations attached to the "resource curse" phenomenon and its escape thereof. Beginning from a point of near-consensus that institutions play an intermediary role in determining the fortune of resource-rich countries, this research protracts the institutionalist argument of proponents like Acemoglu, Johnson and Robinson (2001), filling a sizeable gap in the literature. Although good institutions are widely accepted to help countries escape the resource curse, explanations as to why even though two countries can adopt similar institutions and yet have drastically divergent economic and political outcomes, are still missing from the literature. This study addresses that missing link.

It doing so, the study combined three distinct sets of literature on the way natural resources affect economic and political outcomes in resource-rich countries, making some countries prosperous, stable and democratic, while others remain corrupt, violent 
and repressive. These are the curse of underdevelopment, proponed by Richard Auty (1993) and Jeffrey Sachs and Andrew Warner (1995); the curse of violent conflict put forward by Philippe LeBillon (2005) and Michael Ross (2006), as well as the curse of authoritarianism, emphasized by Douglas Yates (1996) and Terry Karl Lynn (1997) to name a few. By focusing on Botswana, a case which has ostensibly escaped all three curses, the study illuminates the key variables of importance in providing context to the resource curse and its ultimate escape. In addition, it provides a grounded analysis where traditional emphasis of past research has been on policy choices, the macroeconomic environment and the political economy of non-renewable natural resources.

The study examines four key variables that enhance (or hinder) institutional quality. These are legitimacy and historical continuity; political culture; level of ethnic heterogeneity as well as the role of external influences. Largely an empirical project, it employs an eclectic problem-driven approach to research, in which the pursuit of understanding, lead to a variety of methods and insights from purportedly incompatible research traditions. It is expected that the study's results and conclusions will have great implications on the understanding of the way good institutions are brought about, and on the way the resource curse phenomenon will be studied and understood in the future. 


\section{CHAPTER TWO:}

\section{LITERATURE REVIEW AND CONCEPTUAL FRAMEWORK}

Chapter Two maps out the key concepts that give context to Botswana's developmental rarity. Being a diamond exporting country, Botswana is understood as an anomaly of the "resource curse" phenomenon. This dissertation argues that Botswana escaped the resource curse due to its institutional quality. It aims to ascertain how the small landlocked country achieved this high level of institutional quality. This chapter provided the conceptual framework of the three resource curses: the curse of authoritarianism, the curse of violent conflict and the curse of underdevelopment, all empirically observed in resource-exporting countries. The later sections of the chapter will later provide definitions of key terms: institution and institutional quality, and will operationalize these terms in how they will be used to examine the Botswana case.

\section{The "Resource Curse"}

The "resource curse", also referred to as the "paradox of plenty" refers to the contradiction that states whose exports are heavily skewed towards natural resources [(Auty, (1993); Lynn (1997)]. These resources, particularly point-source non-renewable resources such as oil and minerals, tend to have lower economic growth rates and worse development outcomes than their resource-poor counterparts. Many reasons have been posited for this, including a reduced competitiveness of the manufacturing industry through short-term currency appreciation known as the Dutch disease, to the volatility of revenues from resource exports caused by booms and busts in the global economy, government mismanagement of resource revenues, as well as weak and corrupt 
institutions which divert resource wealth for personal benefit [Collier (2003), Sachs and Warner (1995) and Gylfason (2001)].

Evidence of the curse is wide-ranging in scope: from diamond mines in Central and Western Africa, to the oilfields in the Gulf of Guinea and Persian Gulf, where millions of lives have been devastated by the mismanagement of vast revenues originating from non-renewable natural resources. Empirically, a correlation has been established between resource-rich countries and reduced investment in human capital, increased corruption and risky reductions in economic diversification, often resulting in the stagnated economic growth of an otherwise privileged country (Araji and Mohtadi, 2013). The empirical observations of the correlation of resource exports with three negative outcomes, has divided the literature on the "resource curse" into three tiers: the curse of underdevelopment; the curse of authoritarianism and the curse of violent conflict. Botswana, with its record of high levels of economic growth, peace and stability as well as democracy, is assumed by this dissertation to have escaped all three of these resource curses. 


\section{THE THREE RESOURCE CURSES}

\section{The Curse of Underdevelopment}

The first dimension of the resource curse has been its relative effect on a country's rate of economic growth. Countries that are rich and heavily dependent on their extractive sectors generally tend to have slower rates of growth than countries dependent on manufacturing and service sectors. Resource-rich countries are also notorious for not being able to translate windfalls from natural resource wealth into concrete economic and developmental planning.

In a 1995 study, Sachs and Warner examined ninety-seven countries over a period of two decades, using regression analysis to determine the impact of mineral and other natural resource exports on GDP growth. Their study revealed that states with a high natural resource exports to GDP ratio, had unusually slow growth rates between 1971 and 1989. In addition, the correlation remained significant even after Sachs and Warner controlled for a variety of growth- related variables, including initial per capita income, trade policy, investment rates, region, bureaucratic efficiency, terms-of-trade volatility, and income distribution. A study by Weinthal and Luong (2006) discovered that during the period 1965-1998, members of the Organization of Petroleum Exporting Countries (OPEC) experienced nearly universally low or negative annual growth rates. In addition, they revealed that mineral and oil exporters were more likely to incur greater debts even as world commodity prices soared, and were thus forced to commit a significant percentage of their GDP to debt servicing. The authors also observed that mineral rich countries ranked low on indices of the World Bank Governance Research Indicators and the Transparency International's Corruption Perception Index (CPI). 
In addition, citizens in such countries suffered higher levels of poverty, child mortality and income inequality, and had authoritarian regimes as the modal governmental forms. In the past thirty years, the developing world's star performers have been the resource- poor "Asian tigers": South Korea, Taiwan, Hong Kong and Singapore; while many oil and mineral-rich economies such as Iraq, Nigeria, Angola and Venezuela, have lagged behind or stunted economically (Weinthal and Luong, 2006).

Of sixty-five resource-rich countries, only four managed to attain both longterm investment exceeding 25 percent of GDP on average from 1970 to 1998 , similar to that of various industrial resource-poor countries, and per capita GNP growth exceeding 4 percent per year on average, over the same period (Gylfason, 2001). These four are Botswana, Indonesia, Malaysia and Thailand. The three Asian countries achieved this success through diversifying their economies and industrializing, while Botswana, rich in diamonds, mostly without doing so. Between 1960 and 1976 the leading hard-rock mineral exporters in the developing world had average per capita GDP growth rates of 1.9 percent, nearly half the rate of a control group of non-mineral states (ibid).

A number of explanations have been put in place to try to understand the mechanisms and effects of the resource curse on a country's economic development. The traditional explanation for the resource curse has been what the Economist (1977) dubbed the "Dutch Disease," after the effects of the North Sea gas on the Dutch economy. In the 1970's the Netherlands experienced a boom in production of natural gas and exported the fuels in great quantities. The revenues from the gas exports 
resulted in the appreciation of the Dutch guilder against other international currencies. This resulted in Dutch exports becoming more expensive to purchase. As a result, Dutch industries faced more intense foreign completion in international trade, which impacted employment rates and slowed economic growth in the country.

The experience of the Dutch disease in the Netherlands was also reflected in other cases around the world. One example is Nigeria, particularly in the1970's. As revenues from crude oil built up in the country's economy, Nigeria's exports of peanuts and cocoa, in which the majority of the population participated in, became unprofitable as this sector became less attractive to investors and their production collapsed. This hurt the farmers who had produced them, but didn't itself curtail the growth process because traditional export agriculture was generally not a very dynamic sector with many opportunities for technological progress and productivity growth.

However, in this case, as Collier (2007) argues, Dutch disease damaged the growth process by crowding out export activities that otherwise would have the potential to grow rapidly. According to Collier (2007), the Dutch disease generates sectorial reallocation of productive resources in response to a favorable price shock. As a result, there is a transfer of resources, particularly capital and labor, from other sectors such as agriculture and manufacturing. In a country suffering from the Dutch Disease, the growing sector usually entices rural workers away from agricultural production. According to Collier (2007) this contributes to a relative devaluation of local crops.

According to Yates (1996) booming oil (and mineral) sectors distort the patterns of growth on the agricultural and other taxable producing sectors of the 
economy that drive long lasting economic growth. In resource-rich countries, there is a temptation for governments to maintain this artificially high exchange values for their national currencies in order to facilitate the purchasing power of their money. As a result, other sectors within the economy suffer particularly the labor intensive manufactures and services that are believed to be key in driving economic growth, as has been demonstrated in China and India.

Apart from the Dutch Disease explanation, another reason for the development resource curse is the volatility of natural resource commodity prices. Revenue volatility in an oil or mineral exporting developing country hampers planning, increases deficits, escalates spending and tends to raise national debt (Shaxson, 2005). With regards to the last point, when oil or mineral prices are high, countries become more creditworthy to the IMF, World Bank, sovereign donors, and privates credits, and tend to borrow more. However, when prices fall, arrears build up on unpaid debts, increasing debt further. As a result, this boosts prices, interest rates and real exchange rates, thus generating Dutch disease effects that stifle economic growth. Moreover, countries reliant on resource exports discover that the steep price variability on the global market shifted to the domestic economies, making government incomes and foreign exchange supplies unpredictable and private investment prohibitively risky (Ross, 1999).

Rent-seeking is another way in which negative economic growth can result within a natural resource-rich setting. Arezki (2008) highlights that in the absence of definitive property rights; natural resources introduce a common pool problem and 
prompt rent-seeking. According to Visal Khan (2010) rent-seeking occurs when individuals or organizations attempt to produce revenue by seizing economic rents via the manipulation and exploitation of the economic and political environment, in place of earning income through economic transactions and the production of supplementary wealth. In other words, a rent-seeker obtains economic profits without contributing to any economic production. Most instances of rent-seeking occur where there are extractive natural resources or through obtaining the control of land. Rent-seeking can also occur through the imposition of regulations that affect consumers and businesses, and enable the capture of monopoly privileges.

Rent-seeking is thus prevalent in what are known as "rentier" states. Yates (1996) broadly defines "rentier" states as those countries whose main source of revenue is external to the domestic economic system. The structures of most resource-rich countries in Africa can be deemed as rentier due to the fact that they exhibit four characteristics identified by Yates (1996):

1. Rent situations predominate in the economy.

2. The origin of the rent is external to the local economy.

3. Only a few are engaged in the generation of rent, while the majority is involved in its distribution and consumption.

4. The government is the principal recipient of the external rent in the economy (Yates, 1996).

One of the consequences of large amounts of external rents is the fact that the state tends to relax constraints on foreign exchange. This is mainly because in a rentier 
economy, foreign exchange is easily obtainable, thus the state can afford importing goods more cheaply. Imported goods as a result replace domestically produced goods, particularly in agriculture and manufacturing, which cannot compete with foreign goods produced under economies of scale. Another consequence is that government can embark on big capital-intensive development projects. This is mainly due to the fact that, with foreign exchange obtained from external rents, a state can afford more foreign technology, creating the façade of modernization without sustaining the "goods-producing" capacity of the economy (Yates, 1996).

Yates (1996) quotes Mahdavy, who first advanced the rentier-state concept as arguing that resource rents make state officials both "myopic and risk-averse". Upon receiving significant rents, resource-exporters were observed to actively avoid wealth-generating policies due to the guaranteed rents they would obtain from natural resources. He argues that essentially governments develop an irrational sense of optimism about future revenues and dedicate a significant portion of revenues to safeguarding the status quo at the expense of sustained development and democracy. With this observation, Ross (1999) concluded that resource exporters are revenue "satisficers," not revenue "maximizers". In other words, he observed that when a state's demand for revenue diminishes, so will the soundness of its economic policies.

Leonard and Strauss (2003) argue that it is the enclave nature of resource productivity that makes it hinder economic development. Enclave production entails export of primary products that are usually extractive, and that are generated 
in a geographically concentrated area which is widely practiced in the sectors of mining and oil drilling. The enclave idea implies that production is geographically concentrated, a large portion of capital goods and land involved in export production cannot be allotted to other lucrative purposes, and that mobile labor is a minor share of the production cost. Most states on the African continent have a tax base that is built overwhelmingly on revenue generated from commodity sales (oil, minerals, cash crops etc.), and many derive most of their export income from enclave production, thus, making them "enclave economies." Enclave economies are rentier and do not depend on widespread productivity in the population, which goes counter to the labor intensive development models of South Korea, China and Singapore. The state itself does not contribute significantly to the value of production, sometimes not even through provision of physical infrastructure or assurance of security. In that sense, the state collects "rents" from these economic activities, collecting revenue without enhancing productivity. Moreover, production is detached from the general population's economic productivity. Revenue generation is materially confined to small areas, and the main markets are external, making the economic health of areas outside the enclave secondary and at times irrelevant. Thus, the elite do not have a vested interest in mass prosperity, a situation that increases income inequalities within such economies. 


\section{The Curse of Authoritarianism}

The second dimension of the resource curse is the effect of natural resources on political development. Namely, natural resources have been linked to undemocratic political development and authoritarianism. It has for a while been a curious phenomenon that countries that are rich in resources are the ones which fail to exert pressures on their governance structures in for democratic change. By far the most undemocratic region in the world, the Middle East, still remains under the rule of authoritarian regimes. Only five of twenty-five oil-reliant exporters are referred to as democracies. These are Venezuela ${ }^{8}$, Ecuador, Trinidad and Tobago, Indonesia and Malaysia. The rest: Syria, Iran, Iraq, Angola, Equatorial Guinea, Kyrgyz Republic, Cameroon, Brunei, Nigeria, Yemen, Kuwait, Libya, Algeria, Nigeria, Oman, CongoBrazzaville, and Saudi Arabia, were not described as democratic by the Democracy Index (2010). Sub- Saharan African countries currently under dictatorships include Angola, under Jose Eduardo dos Santos, Equatorial Guinea under Teodoro Obiang Nguema Mbasogo, Cameroon under Paul Biya and Sudan, under Omar Hasan Ahmad al-Bashir. All of these countries derive a great proportion of their Gross Domestic Product from the export of oil (CIA, 2010). Other oil and mineral-rich countries have also suffered periods of authoritarian rule in history, including Iraq under Saddam Hussein, Nigeria under Ibrahim Babangida and Zaire (now Democratic Republic of Congo) under Mobutu Sese Seko. In fact, Mobutu utilized the mineral resources in his country for his own self-enrichment, approximated by Transparency International to

\footnotetext{
${ }^{8}$ In Venezuela, President Chávez currently governs by Presidential decree thus undermining the judicial branch and the legislature, etc. "To all appearances, Venezuela seems to be a democracy in the process of failing."
} 
total US\$5 billion thus leading to a kleptocratic government (Transparency International, 2006).

In his groundbreaking paper “Does Oil Hinder Democracy?” Michael Ross isolated three mechanisms in which the resource curse may impede political development. These are a) the interplay of the rentier effect, b) the repression of oil states, and c) the lack of modernization that inhibits the development of democracy. According to Ross (1999), the rentier effect separates fiscal relationships between the government and citizens, and occurs through three mechanisms: the taxation effect, the spending effect and the group formation effect. The taxation effect refers to the relief of an oil-rich state from levying a tax burden on its population. The citizens are relived from paying taxes to the state because revenues from the oil or mineral rents are sufficient to run state budgets. Traditionally, the payment of taxes is what links civil society to the democratic process, and in the absence of a tax base, the government thus becomes less accountable to the society that it governs (Ross, 1999). In a rentier state, setting up a tax system would only produce a small fraction of the tax revenue obtained from the resource rent. As a result, this has the effect of reducing citizens' democratic voice, as the dictum goes "no representation without taxation." The absence of representative institutions like taxation thus makes the government less accountable.

The second way the rentier effect works is through a "spending effect." The spending effect occurs when a state that is heavily dependent on resource rents, spends or is prone to spending a lot of money establishing and maintaining patronage networks. According to Berman (1997), patron-client relationships have remained 
fundamental state-society linkages in sub-Saharan Africa. Therefore, those who favor lengthened political incumbency pay off clients with revenues generated from resource sales in order to gain politically. This poses a serious challenge to the forces of democratization.

The second broader mechanism that Ross isolates is the "repression mechanism". Generally, Ross argues that when a state is rentier, it invests in security forces that secure political incumbents from challengers to their office. This greatly diminishes the political voice of the citizens. An example of this is in countries where peaceful demonstrations are deemed illegal. Large flows of oil money encourage leaders to spend excessively on regime defenses. For example, since before 1979, Iranian expenditure has been spent on the security of the Shah and the survival of his regime (Global Security, 2011). Qatar and Oman, both oil-exporters, spend over 10 percent of their GDP on military expenditures (ibid). The presence of elite defense "national guards", known as the Mukhabarats in Middle Eastern countries, had the effect of suppressing opposition. Oil wealth, in addition, increases expenditure on arms. Global Witness (2002) argues that in Angola, various illegal schemes were put in place to facilitate the exchange of oil for arms that fueled the ongoing civil war.

The third mechanism that Ross describes when discussing the effects of resources on democracy is known as the "modernization effect," following the work of Inglehart and Welzel, (2005). Generally, Inglehart's research demonstrates a positive correlation between economic development, education and democracy. Citing Inglehart and Welzel (2005), Ross (1999) argues that democracy is most likely to emerge and 
survive when certain social and cultural conditions are in place. He argues that when modernization sets in, it tends to permeate other aspects of life, bringing with it positive feedback, and reinforcing transformations to political institutions. This has the effect of enhancing occupational specialization, prompting urbanization, raising educational levels, life expectancy and other human development indicators, as well as increasing the primary rate of economic growth. Additionally, modernization raises mass political participation and ultimately enables the fortification of democratic political institutions. According to Gylfason (2001)'s empirical research, resource-rich countries tend to spend less on education than their resource-poor counterparts, thus limiting democratic growth.

Natural resources provide the structural base for personal rule and neopatrimonialism (Englebert, 2000). Neopatrimonialism has been viewed in subSaharan African literature as the equilibrium result of the mismatch between precolonial and colonial political organization (ibid). In sub- Saharan Africa, neopatrimonialism has well been established to be the modal form of politics (Bratton, 1994). In such countries, regimes collect and distribute "rents" as patronage instead of developing infrastructure and institutional capacities for broad-based markets. One key element of personal rule is the counterproductive development policy, in the forms of unpredictable economic policy and strategies of private accumulation through public means. Countries characterized by personal rule have a number of key characteristics identified by Leonard and Strauss (2003). These include the fact that 
1. Appointment and position in government generally depend on loyalty to one's superior and not on adherence to impersonal norms;

2. Transactions are personalized and office is treated as a form of personal property and a source of private gain (known in Weberian terms as a "prebend"); and,

3. A clear sense of a public interest that transcends private ones does not exist.

This type of political system has been attributed to Africa's colonial history (Leonard and Strauss, 2003). In pre-colonial times, small African states existed which were highly centralized and hierarchical. The chief was in many cases the singular custodian of natural resources, and access and distribution of those resources was done along patron-client lines. Hyden (1997) asserts that historically, personal rule existed in most world regions and that a lineage orientation persisted where kinship networks and other primary reciprocities governed communities. However, informal rules have greater salience than formal ones and rational-legal authority has gained less traction in modern African settings. While other countries have moved on to more efficient forms of governance, Africa has maintained its hierarchical "community-centered orientation" (Hyden 2006:56).

Natural resources help fuel personalistic rule. One extreme example is that of Mobutu Sese Seko's Zaire (now Democratic Republic of Congo). In his thirty years in power, Mobutu succeeded in generating huge amounts of wealth for himself and his clients, while 99 percent of that country's population faced a disintegrating economy. To survive, Mobutu only needed to maintain diamond, gold, copper, cobalt and other minerals, as well as collect foreign aid to protect his state and perpetuate his rule 
(Dunning, 2005). Thus, in this example, natural resources were used to sustain a corrupt government.

Hanne Fjelde (2008) argues that political corruption accommodates opposition and pacifies restless groups by offering private privilege for political loyalty. As a result, this provides an economic foundation for clientelist rule (Fjelde, 2008). This author cites Gabonese President Bongo's administration as a classic manifestation of cronyism. According to Fjelde, Bongo after the 1970's pursued a co-optation policy of the middle class through public expenditure. Nevertheless, political stability in Gabon has greatly depended on the president's patronage networks. In addition, limited organized opposition to Gadhafi's regime in Libya made rent-seeking dominate citizenry behavior as the government used oil revenues as a strategic commodity in buying off political competitions, resulting in rentier peace. Events in 2011, however, suggest the limits of using resource revenues to buy off the political opposition, at least in Libya.

The resource curse has resulted in diverging experiences for countries where peace and stability are concerned. On one end, it has fostered rentier peace through authoritarianism and neopatrimonialistic networks, and on the other hand, it has been linked to an increase in civil war and violent conflict. The following section looks at how natural resource abundance leads to violent conflict.

\section{The Curse of Violent Conflict}

In addition to having negative effects on countries' economic growth, natural resources have also been seen to affect the incidence of violent conflicts worldwide. 
Needless to say, the geography of conflict is curiously located in areas with a large amount of valuable natural resources and these regions have as a result, gained strategic importance and concern in the military planning of the US and the United Nations (Klare, 2001). The 2003 and 2004 coup attempts in Equatorial Guinea, and the Congo- Brazzaville's civil wars of the 1990's, have been greatly attributed to the levels of oil exportation in these countries. The oil-rich region of the Niger Delta has also been the setting of many conflicts, such as the Warri (Port Harcourt) conflicts between the Niger Delta Vigilantes and the Niger Delta People's Volunteer Force and the IjawItsekiri conflicts (Human Rights Watch, 2005). In addition, one of the world's most famous and valuable diamonds, the Millennium Star, a 203.04 carat (155.4g) originated from the DRC in the years preceding its civil war?

Other natural resources, like diamonds mined in war zone areas, have been used to finance insurgencies and warlord activities. These have now come to be named "conflict diamonds" or "blood diamonds." The 1974-2001 civil war in Angola saw one side of the war; the government backed Popular Movement for the Liberation of Angola (MPLA) being funded by oil revenue, and the rebel group the National Union for the Total Independence of Angola (UNITA) being funded by diamond revenues. In fact, according to Arnold (2000:131), UNITA sold diamonds, in the value of US\$3.72 billion towards funding the war against the Angolan government. Cabinda, an oil rich enclave of Angola, has played host to a violent secessionist movement, the Front for the Liberation of the Enclave of Cabinda (FLEC), whose ethnic group, the Bakongo planned in order to separate the province from Angola.

\footnotetext{
${ }^{9}$ http://burbankdigest.com/node/37
} 
The rationale for the relationship between resource wealth and violent conflict, stemmed mainly from two hypotheses which provide the motivation for civil war as a result of resource endowments. These competing rationales are the greed theory and the grievance theory. The greed theory postulated by Collier \& Hoeffler (2005) argues that wealth in primary commodities escalates the probability of civil war onset by providing occasions and motivation for armed rebel activity. The "greedy rebels" mechanism thus suggests that the booty character of natural resources encourages rebels to take up arms or continue fighting. Furthermore, "greedy outsiders" might be ready to intervene militarily either directly or through support for internal warring factions as a way to gain or maintain control over productive resources, such as was the involvement of Rwanda and Uganda in the Second Congo War.

In contrast, the "grievance" transmission channel suggests that the perceived deprivation of producing regions and social groups, or the indirect negative economic consequences of resource wealth, create grievances that trigger violent uprising, particularly secessionist movements. In such cases, resource wealth promotes civil war by giving people who live in resource-rich areas the economic incentive to establish a separate state. Most regions that are resource-rich coincidentally tend to be inhabited by people of distinct ethnic, linguistic, or religious identities that set them apart from the majority population and as a result, they are usually disenfranchised. This has been the rationale behind secessionist movements in the natural gas rich region of Aceh in Indonesia, the oil-rich enclave of Cabinda in Angola, oil-rich Biafra in Nigeria, and natural gas-rich southern Sudan. However, most authors including 
Collier and Hoeffler (2005) place more emphasis on greed being a motivation for civil conflict instead on the grievance mechanism.

Michael Ross (2002) argues that there are other mechanisms that could result in resource abundance leading to civil war, such as a rapid decline on economic growth. He observed that the civil wars in DRC, Sierra Leona and Liberia were all preceded by a rapid decline in GDP per capita. In addition, he argues that natural resources weaken a state's institutions and bureaucracy, and fosters corruption. Most corruption is found in resource-rich countries, for example, an IMF report indicates that Angola failed to account for almost $\$ 1$ billion due to corruption.

Ross (2002) posits that resource dependence overwhelms a state's budgetary processes. Incumbents tend to use money to obtain patronage, which further weakens state institutions and makes it corrupt. As a result, states lack accountability to their citizens, and fail to provide for the necessary state security apparatus that would keep the country stable. They do however; build up security forces in order to protect the regimes themselves, but not the citizens of the country.

Finally, Ross (2002) argues that resource abundance provides an opportunity for rebel financing. When Angola's UNITA lost its financial backing from the United States at the end of the Cold war and the apartheid era in South Africa, it turned to its diamond revenue for supporting military expenses. Similarly, the Khmer Rouge of Cambodia sold timber and gemstones to fund its military exploits, and the FARC in Colombia trafficked cocaine. Resources like diamonds and oil produce high rents and are usually done in a specific location, making looting and extortion feasible. 
According to Pierre Englebert and Ron James (2006), in 1997 in Congo-Brazzaville, the private militia of President Sassou-Nguesso was funded by the sale of war booty and the rights to future exploitation rights to the country's oil reserves.

Although natural resource wealth has been blamed for inducing slow economic growth, authoritarianism, and sparking violent conflict, this research argues that these effects are mediated by the quality of institutions that are in place. The following section provides a background to the intermediary role played by economic and political institutions.

\section{INSTITUTIONS AND THE RESOURCE CURSE}

Despite the fact that a resource curse is apparent in many resource-rich countries, it is not a universal phenomenon. For every two or three countries that exhibit symptoms of the curse, there is a relative success story. Thus, the empirical fact that natural resources are negatively correlated with economic growth must be reconciled with the fact that there have been these varying outcomes across countries. An emerging group of scholars are now arguing that the resource curse is far from inevitable. Citing the relative successes of countries like Norway and regions like Alaska having become affluent thanks to their resource endowments, they argue for a new interpretation for the fate of resource-rich countries. Boschini, Petterson and Roine (2007) argue that resource wealth alone does not affect whether a country suffers the resource curse. Instead, the incidence of the curse hinges upon the quality of a state's institutions. Therefore, in the view of proponents of the view, given the right 
institutional framework, non-renewable resources can potentially boost a country's economic and human development (Boschini, Petterson and Roine, 2007).

Three divergent strands of thought have emerged within the literature as to how institutions affect the resource curse. The first are those who argue that institutions do not play a significant role; rather, it is resources that directly cause the curse. A second strand argues that institutions are depreciated by resource wealth and thus constitute an intermediary causal relation between resources and economic performance. A third strand argues that resources interact with institutional quality. When institutions are good, resources become a blessing and when they are bad, the resource curse occurs.

Michael Ross falls within the first strand in his research of the relationship between oil dependency and democracy. He shows that oil dependency hinders democracy. Jeffrey Sachs and Andrew Warner (1995) on the other hand, reject the hypothesis that institutions or bureaucratic quality play a role in explaining the resource curse, instead placing heavy emphasis on the Dutch disease as an empirically relevant explanation for the resource curse.

Mehlum, Moene and Torvik (2005) however, predict that in countries with functional institutions, resource wealth invites entrepreneurs into production, and in countries with fragile institutions, entrepreneurs are sidetracked from production and into unsustainable rent appropriation. They assert that the variance of growth performance among resource exporters is primarily due to rents being dispersed through a country's institutional arrangements. They distinguish between "producerfriendly" institutions in which rent-seeking activities complement economic production, and "grabber-friendly" institutions, where rent-seeking competes with 
production. The aims of grabber-friendly institutions according to the authors, is to gain from specialization in unproductive environments characterized by weak rule of law, malfunctioning bureaucracy and corruption. They attract entrepreneurial resources out of production, implying negative economic growth. Similarly, Robinson, Torviki and Verdier (2005) argue that depending on the quality of institutions, politicians favor certain policies over others in reaction to incentives brought about by resource booms. Low quality institutions attract bad policy choices since they permit politicians to participate in inefficient redistribution in order to influence election outcomes. In contrast, good quality institutions make such political strategies infeasible or relatively unappealing. Scholars who emphasize the role of institutions in the resource curse have an optimistic outlook on escaping the resource curse and believe that with the right laws and structural adjustments, resource-rich countries can escape the resource curse. They look to the creation of savings funds, policies aimed at the diversification of the economy to relieve dependency on resources, and income redistribution, as ways in which resource-rich countries can gain favorably from their resource endowments (Alayli, 2005).

However, one problematic of this view is its simplified view of primitive predatory behavior. Rosser (2006) argues that the nature of institutions in resource exporters is determined by enduring social patterns and dynamics, principally where natural resource domination of the economy occurred subsequent to state formation. In such instances, resource endowments entered into ongoing processes of development and into a constellation of identities. Michael Watts extended this line of thought in his research on Nigeria. He explores how petro-capitalism produced 
forms of rule and political authority, what he called "governable spaces" from the realities within which it was inserted (Watts, 2004). Therefore the counter-argument to the resource curse is that the difference between countries that benefit from resources and those that do not is the institutional setting into which the natural resources are inserted.

The evolution of institutional arrangements has not been immune, however, to the effects of natural resources. According to Basedau (2005), adversarial colonial legacies and rentierism weakens state institutions and elicits poor economic policies. Historically, in African resource-rich countries, political institutions and property rights where developed in order to ensure the efficient extraction of valuable natural resources. In colonial Africa, institutions were created with a bias towards empowering the colonial elite to extract minerals or plant cash crops. As a result, secure property rights were only provided for the politically and socially powerful colonial elite.

Institutional quality is thought to be determined by the reliance of economic rents from natural resources. Ross (2003) argues that natural resource revenues can deteriorate a government's resolve to address social conflicts in two ways: by impeding the state bureaucracy's effectiveness, and by weakening the state's monopoly on territorial control. He argues that a state's strength comes from its ability to tax its citizens. In the presence of abundant natural resources, this capacity is undermined as the state find less incentive to establish tax infrastructure due to the ease of obtaining economic rents. 
Furthermore, if a country has valuable resources that can be artisanally mined, like coltan, tanzanite, and alluvial diamonds, the state's monopoly on law and order in the extractive region may be compromised. Such "lootable" minerals attract rural miners who usually resort to extralegal and sometimes violent measures to establish claims and adjudicate disputes. The high value-to-weight ratios of these resources compromise their taxability, facilitating for easy smuggling. Furthermore, as Basedau (2005) argues, they produce high corruption levels inside the government and beyond. In certain cases, this combination of weak institutions, corrupt government, compromised authority, and resilient criminal organization, can escalate to the rise of rebel movements.

In the case of Botswana, however, resource abundance has not come at the expense of economic development, peace and security, or even democracy. The existence of diamond wealth has not acted as an incentive for the economic elite to create neo-patrimonialistic network systems. Neither has the presence of diamond wealth created a disincentive for taxation. Property rights have been efficiently allocated, and the state has great monopoly over the control of resource extraction. This dissertation begins from Acemoglu, Johnson and Robinson (2001)'s assertion that despite initial economic and geographic disadvantages during the colonial period, Botswana attained rapid development due to quality institutions. This begs the question: Why have Botswana's institutions been so robust? Why has diamond wealth not been as much of an incentive for bad behavior in Botswana as it has been in other sub-Saharan natural resource-rich countries? The following section will 
operationalize the terms "institution" and "institutional quality" within the context of this dissertation.

\section{Defining Institutions}

According to Michael Bratton (2011), institutionalism assumes that ordinary people, when thinking and acting politically, obtain cues from the customary structures predominant in their local polities. Therefore, institutions provide a revealing aperture through which to view and explain uniformities in human behavior, public opinion and mass participation. Douglass North (1990) defines institutions as "humanly devised constraints that structure political, economic and social interaction." Institutions, he argues, consist of both informal constraints, such as taboos, sanctions, customs, traditions and codes of conduct, as well as formal rules, such as constitutions, laws and property rights. Throughout history, institutions have created order and reduced the uncertainty normally attached to exchanges.

North states that understanding the need to constrain human interaction with institutions can best be explained within a game theoretic context. Wealth-maximizing individuals usually find it worthwhile to collaborate with other players when three conditions are met. These conditions are: repeated plays; access to knowledge about the past performance of the other player; and a small number of players. In contrast, the sustainability of cooperation is problematic when the game is not repeated or there is an endgame; when there is a lack of information on the other players; and where the number of players is large. 
In an economy, North (1990) argues that institutions provide an incentive structure, and as this structure evolves, so does the direction of economic change towards growth, stagnation, or decline. However, there exists a difference between formal and informal institutions.

Formal vs. Informal Institutions

Formal institutions consist of written rules and constraints such as a constitution, the law and regulations etc. (Siedler, 2011:4). According to Frances (2004:6), "they contribute to political stability, prevent corruption, enhance public sector efficiency, and protect private property rights from misappropriation by private parties or government ${ }^{10,}$. Four constitutional constraints serve to limit government predation. These constraints are plurality, proportional representation, judicial independence, and constitutional review, and can be classified as either electoral rules or judicial constraints. Electoral rules, indicated by plurality and proportional representation, act as checks on executive power, while judicial constraints, measured by judicial independence and constitutional review, capture the limits on the executive dispensed by the judiciary (Williamson and Kerekes, 2011).

For Bratton (2007:2), "formal institutions are the organized routines of political democracy, such as regular elections for top officeholders and legal constraints on the political executive". Bratton (2007) refers to proponents who favor explanations emphasizing the role of formal institutions as "formalists", and argues that in studying

${ }^{10}$ http://www.treasury.govt.nz/publications/research-policy/wp/2004/04-19/twp04-19.pdf 
Africa, "formalists" contend that the nature of official state institutions decisively shapes citizens' stances toward democracy. Relevant formal institution variables include whether the constitution is unitary or federal, presidential or parliamentary; whether the electoral system is majoritarian, plurality-based, or proportional; and whether the party system is fragmented or if one party dominates it. For instance, Donald Horowitz, who Bratton identifies as a "formalist", has argued that federal constitutions help to ease political conflict in deeply divided societies such as most in Africa. Furthermore, Andrew Reynolds recommends proportionate representation as an electoral formula to safeguard minority rights. Similarly, Daniel Posner argues that effectiveness of the party system affects whether ethnic groups organize along language, cultural or tribal lines. These are all explanations that emphasize the role of formal institutions in economic and political developmental outcomes.

Informal institutions, on the other hand, are unwritten norms of repeated human interactions. They embody moral codes and norms, which can be very diverse across cultures (North 2005:50). Williamson and Kerekes (2011) describe informal institutions as those rules that shape human behavior but are outside of government and are not part of a written legal framework. These private mechanisms guide everyday interactions and shape a way of life within a given region include social norms, customs, attitudes, beliefs about right and wrong, and rules of enforcement (North 1990). In informal institutions, constraints are persistent over time and show depth and durability.

Williamson and Kerekes identified four separate classes of culture that they assume constrict behavior related to economic and societal interaction. These four are 
trust, respect, individual self-determination and obedience. Trust, they argue, reduces transaction costs, resulting in efficient outcomes and the continuance of market exchange (Fukuyama 1996; La Porta, Lopez de-Silanes, Shleifer and Vishny 1997 etc.). The second component of culture captures the determination of individuals to succeed, which is determined by the level of individual self-control individual over choices. The third cultural trait is defined as respect. Some societies condone opportunistic behavior outside immediate networks, while others promote social interactions beyond immediate groups. The fourth and final cultural trait captures obedience as an important to society. Tabellini (2009) argues that certain societies teach that disparage individualism and find it to be destructive.

Within the African context, Bratton (2007) refers to informal institutions as the patterns of patron-client relations by which power is exercised. He argues that "informalists" (those who emphasize the efficacy of informal institutions), view official state institutions as generally weak in Africa, where unwritten rules hold far more sway. He argues that the role of informal institutions in Africa derive from a social logic known as "the economy of affection." He posits that informal institutions such as charisma: the authority relationships based on personal trust; clientilism: the expression of political loyalty to providers of patronage; pooling: horizontal exchanges within small groups; and collective self-defense: such as the development of common norms of sovereignty and noninterference, are what prevail in Africa (Bratton, 2007:98). He argues that in nascent democracies, formal institutions are either underdeveloped or ignored with impunity, usually in deference to individual or communal ties. This results in the influence of 
formal institutions being sharply attenuated as political actors align themselves with more familiar relationships and practices.

Table 2.1 provides a hierarchy of institutions according to an "informalist," Valentin Siedler (2011). As is reflected in the table, informalists argue that informal institutions impose the most constraints on formal institutions. As a result, they rank informal institutions highest within the institutional hierarchy. Their assumption views human behavior as being shaped more by informal institutions, such as moral codes based on kinship, more than by formal institutions such as the written law, particularly when the two are in conflict (Williamson 2000: 596-598).

Table 2. 1: Hierarchy of Institutions

\begin{tabular}{|l|l|l|l|}
\hline Level & Examples & Changeability & Effect \\
\hline $\begin{array}{l}1 . \quad \text { Informal } \\
\text { institutions related to } \\
\text { social structure of the } \\
\text { society }\end{array}$ & $\begin{array}{l}\text { Cultural norms, } \\
\text { religion, customs }\end{array}$ & $\begin{array}{l}\text { Very persistent to } \\
\text { change. 100-1000 years }\end{array}$ & $\begin{array}{l}\text { Defines the way a } \\
\text { society conducts itself }\end{array}$ \\
\hline $\begin{array}{l}2 . \quad \text { Formal } \\
\text { institutions related to law } \\
\text { and bureaucracy }\end{array}$ & $\begin{array}{l}\text { Formal rules defining } \\
\text { property rights, the } \\
\text { judiciary system }\end{array}$ & $\begin{array}{l}\text { Long horizon to change } \\
\text { (10-100). Shocks and } \\
\text { crises may affect } \\
\text { sudden change. }\end{array}$ & $\begin{array}{l}\text { Defines overall } \\
\text { institutional } \\
\text { framework }\end{array}$ \\
\hline $\begin{array}{l}\text { 3. Formal } \\
\text { institutions related to } \\
\text { governance and rules of } \\
\text { doing business }\end{array}$ & $\begin{array}{l}\text { Specific laws and } \\
\text { regulations defining } \\
\text { contractual relations } \\
\text { (e.g. limitation of } \\
\text { liability, business } \\
\text { contracts) }\end{array}$ & $\begin{array}{l}\text { Mid-term horizon (1-10 } \\
\text { years) }\end{array}$ & $\begin{array}{l}\text { Defines the "rules of } \\
\text { the game" }\end{array}$ \\
\hline $\begin{array}{l}\text { 4. Formal } \\
\text { institutions which } \\
\text { regulate resource } \\
\text { allocation (incl. } \\
\text { employment) }\end{array}$ & $\begin{array}{l}\text { Adjustments of prices } \\
\text { according to } \\
\text { neoclassical analysis, } \\
\text { setting incentives }\end{array}$ & $\begin{array}{l}\text { Short time adjustments, } \\
\text { continuous }\end{array}$ & $\begin{array}{l}\text { Define marginal } \\
\text { conditions under } \\
\text { markets function. }\end{array}$ \\
\hline
\end{tabular}

Source: Siedler, 2011:5 (based on Williamson 2000 and Jütting 2003) 
This dissertation acknowledges the contribution of both formal and informal institutions in determining Botswana's developmental success.

\section{Defining Institutional Quality}

According to North (1990), effective institutions raise the benefits of cooperative solutions or the costs of defection. They reduce transaction and production costs per exchange so that potential gains are realizable. According to the Bertlesmann Transformation Index (2010), institutional quality can be determined by indicators such as the level of stateness, a country's monopoly on the use of force, the level of political participation, the exercise of free and fair elections, association and assembly rights, freedom of expression, the rule of law, separation of powers, independent judiciary, prosecution of office abuse, and stability and performance of democratic institutions. Economic institutional quality is determined by levels of market organization, antimonopoly policy, currency and price stability, macro-stability and private property. In this study it has been well established that Botswana has a high level of institutional quality. According to the Bertlesmann Transformation Index (2010), Botswana scored a value of 8.4 for democracy status, 8.0 for rule of law, and 9.0 for stability of political institutions. This is in comparison with Angola, Nigeria and the DRC who scored 4.85, 4.80 , and 3.60 for democracy status respectively, 4.05 .3 and 2.8 for rule of law respectively, and 3.0, 2.0 and 2.0 respectively for stability of democratic institutions, with the highest ideal score achievable for all areas being 10. Similarly, whereas Botswana 
scored 7.2 for market economy status, Angola, Nigeria and DRC scored 4.25, 5.04 and 2.79 respectively $(\mathrm{BTI}, 2010)^{11}$.

This dissertation describes institutional quality as institutions that reflect characteristics of good governance. These eight characteristics are transparency, accountability responsiveness, equitable and inclusive, effective and efficient, follow the rule of law, participatory and consensus oriented.

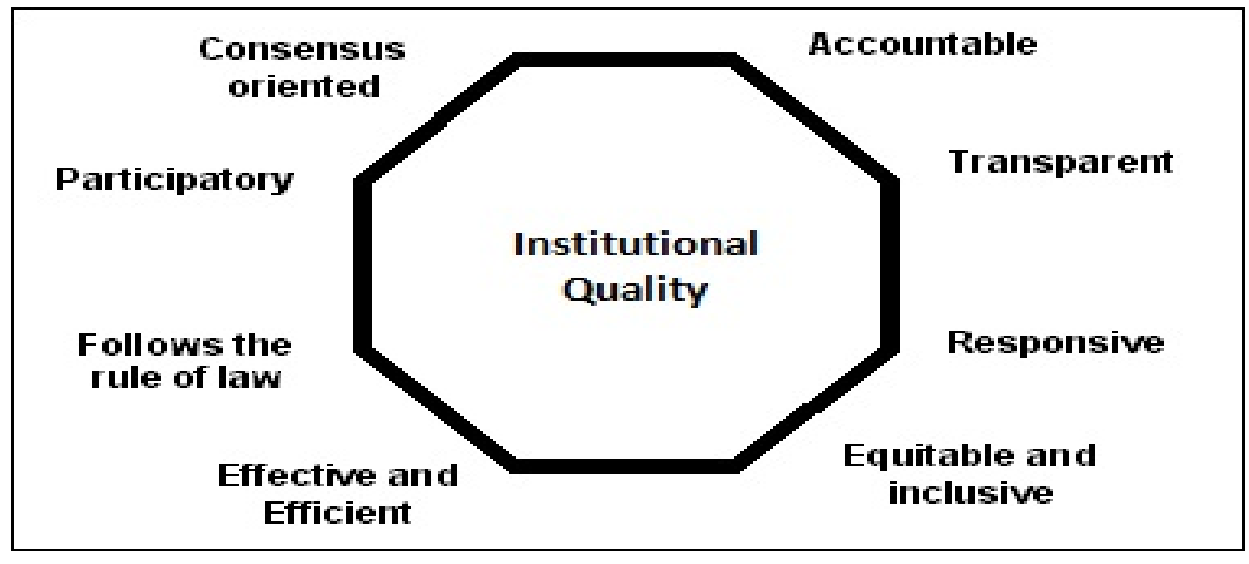

Figure 2.1: The Eight Characteristics of Institutional Quality

\section{Own Adopted from UNESCAP (2013)}

Institutional quality connotes freedom of association and expression as well as an organized civil society. Hence, participation is a keystone of institutional quality. Institutional quality reflects fair legal frameworks that are enforced impartially. It requires protection of human rights, particularly of minorities, as well as vulnerable and marginalized populations. Enforcement of laws should be impartial and police force should be incorruptible. Transparency refers to the taking of decisions in a manner that follows rules and regulations. Information is freely available and directly accessible to

\footnotetext{
${ }^{11}$ For more statistics on the Bertlesmann Transformation Index, please refer to Appendix III, IV and V
} 
those affected by decisions and their enforcement. Institutional quality connotes that processes serve all stakeholders within a reasonable timeframe. Institutional quality is also consensus oriented and open to a plurality of viewpoints. It requires mediation of different interests to reach a broader consensus in society. This consensus should also bear a long-term perspective, and reflect an understanding of the historical, cultural and social contexts of a given society or community. Institutional quality insinuates societal wellbeing as dependent on equity and inclusiveness. Furthermore, it means institutions and processes produce results that meet societal needs and make the best use of societal resources. Efficient institutions sustainably utilize natural resources and protect the environment. Accountability is a key indicator of institutional quality. Institutions should be accountable to those affected by their decisions and actions, and cannot be enforced without transparency and the rule of law, UNESCAP (2013). Appendices III, IV and V depict institutional quality scores according to the Bertelsmann Transformation Index in comparative perspective.

This dissertation will use these criteria as measures of institutional quality and will qualitatively evaluate to what extent historical continuity and legitimacy, political culture, ethnicity and identity management as well as external actors, affected these measures that reflect the robustness of institutions in Botswana. 


\section{CHAPTER THREE:}

\section{LEGITIMACY AND INSTITUTIONAL CONTINUITY IN BOTSWANA}

This chapter explores Botswana's history and the context that it created for the establishment of Tswana institutions. Specifically, the chapter tests the idea that due to a lack of institutional disruption from pre-colonial, through colonial, to post-colonial times, Botswana experienced a rare level of institutional continuity that other sub-Saharan African countries did not experience. As a result, the adoption of post-colonial institutions whose principles greatly resembled those of pre-colonial institutions had the added benefit of legitimizing the type of authority that was exercised by Tswana rulers. As a result, Tswana authorities did not have to compete with newer forms of governance as in other African countries disrupted by the forces of slavery and imperialism.

Before Botswana became an independent country in 1966, the poor, arid, and landlocked country was one of the most neglected crown colonies ${ }^{12}$ of the British Empire. It was surrounded by states ruled by hostile white regimes, including Rhodesia (Zimbabwe) to the east, South West Africa (Namibia) to the west, and apartheid South Africa to the south. Many argue that Botswana was actually never fully colonized (Keene, 2001), but rather was a protectorate of Britain (Morton, Ramsay and Mgadla, 2008). British colonial policy greatly varied in sub-Saharan Africa. In West Africa, the British exercised indirect rule, whereby the colony was administered through existing traditional structures. In the case of Nigeria, the chiefs where used to run the British administration. In most of southern Africa however, because most of the colonies were settler colonies, where people of European descent established permanent settlements, a

\footnotetext{
${ }^{12}$ Crown Colony
} 
system of segregation was put in place. The most commonly known form of this was apartheid (Gallagher, 2002), which greatly undermined the authority of traditional governance systems and imposed new power structures to the detriment of indigenous populations. However, unlike its neighbors, Botswana had minimal hostilities with its white population, who generally never seriously attempted to permanently settle in the country. Upon independence, the native Botswana population was able to reach a cordial compromise, adopting British institutions, not entirely as a result of coercion, but as a pragmatic negotiation that would equally represent all Botswana citizens without the disturbance of tribal politics. Furthermore, the principles of liberal democracy espoused by the British institutions such as the rule of law, equality, and freedom of expression, greatly resembled those of traditional Tswana institutions.

The chapter is divided into five sections. The first section will provide a theoretical framework of the concepts of legitimacy and continuity. The second section is a historical exploration into the foundations of state and political legitimacy in Botswana throughout the pre-colonial, colonial, and post-colonial period. The third section consists of views by respondents of this research about their views on the legitimacy of Botswana's pre-colonial institutions in the post-colonial era. The fourth section explores legitimacy and continuity on a comparative perspective and the fifth section concludes the chapter. 


\section{Chapter's Theoretical Framework: The Concept of Legitimacy}

Central to this chapter's argument is that Botswana has a rare level of legitimacy that does not occur to the same extent in other resource-exporting countries in Africa and beyond. In Economy and Society, Weber (1978) [in Roth and Wittich (1978)], argued that "the medium for all forms of exchange in society is power in all of its manifestation", a foundational understanding that is still generally accepted. According to Weber, confidence in a political system's legitimacy directly enhances the state's stability. Emphasizing the behavioral facets of power, he gave political domination preeminence as the key variant of power. For Weber, the level of domination is the likelihood that specific commands will be followed by a given group or community, of their own free will, without intimidation or coercion. He argued that there are precise conditions that qualify for domination to occur. These are "custom and the material calculation of advantage". However, these do not form a sufficiently reliable basis for domination. Instead, a further element of domination that abets this advantage is the belief in legitimacy [Weber, in Roth and Wittich (1978)].

Thus Weber notes that while solidarity, the material advantage, and custom are essential to exercise authority, they are inadequate in supporting it. Only when a strong belief in the legitimacy of the authority in question occurs, will there be sufficient basis to decree the authority and activate its power. It is important to note that Weber did not mean that domination is legitimate, i.e., that it ought to exist. Rather, he meant that a community has belief in the legitimacy or validity of an authority under question, which in turn expedites their control over that community. Domination in this context requires 
what Weber calls a "staff," - the agents of the ruler ${ }^{13}$ (in this case the community). Thus, the presence of domination is a triangular linkage between the ruler, the staff, and the subjects.

This dissertation argues that the fact that Botswana has been a peaceful and stable country and a nominally democratic country in sub-Saharan Africa is a result of the voluntary endorsement of the authority bestowed upon the state by its citizens. This endorsement reveals its legitimacy.

Weber isolates three bases for legitimate authority. The first basis is on rational grounds. Rational legitimacy rests on a belief in the legality of rule and of those put into power under those rules to issue commands. The second basis of legitimacy occurs on traditional grounds, resting on "the belief in the sanctity of immemorial traditions and the legitimacy of those exercising authority under them". Lastly, charismatic legitimacy rests on "the devotion to the exceptional sanctity, heroism, or exemplary character of an individual person or a group and the normative patterns of orders revealed or ordained by him"/them [Weber in Appelrouth and Edles (2009:179)]. These sources of legitimacy are rarely found in their pure form. Rather, Weber conceives them as archetypes of authority, which are not mutually exclusive. As a result, more ways than one can exist of legitimizing authority [Weber, in Roth and Wittich (1978: 263)]. This dissertation argues that all three forms of legitimacy played a role in nurturing institutional quality in Botswana, evidence of which will be presented later in the chapter.

\footnotetext{
${ }^{13}$ http://forums.infoshop.org/viewtopic.php?f=29\&t=8797
} 
The legitimacy of authority that Weber posits depends on the level of analysis of the case in question. The level of analysis adopted by this research is the state level. Max Weber's state is a "human community that successfully claims monopoly of the legitimate use of use of physical force within a given territory" [(Weber 1958:78) in Warren 2004:6)]. Seymour Martin Lipset (1959:86), states that state legitimacy “involves the capacity of the political system to engender and maintain the belief that the existing political institutions are the most appropriate ones for the society". This definition conjures up a positive orientation among the populace toward the governing political regime as providing a satisfactory order, and holding the belief that no alternative would be superior. This is essentially a Weberian understanding of "legitimacy" in that its conceptualization depends not so much on the conduct of leaders or the design of institutions, but on how these are judged by those whom the leaders and institutions claim to governance.

In relation to the territorial state, generally regarded as the ideal form of state, legitimacy empowers central state agents to inspire the willing cooperation and compliance of individual citizens without a heavy reliance on surveillance or coercion. This ability comes from the regard by most citizens that the agents are the most appropriate for making and implementing laws, policies, and programs on their behalf. This occurs regardless of the short-term performance or popularity of singular programs, policies, or the leaders who endorse them. Thus, an exploration of the level and sources of state legitimacy is essentially an analysis of the evolution and structure of state-society relations, with "society" denoting the array of institutions and social relations constructed by sub-state actors (Sil and Chen, 2004). 
When historical patterns of statecraft are considered, various types of states evolved over centuries. These were shaped by domestic relations of power and by warfare with neighboring entities, as the case in most of Western Europe. Others were essentially unchallenged by external forces for very long periods of time and developed into large-scale empires and some from having been born of social contracts. Throughout history, there have been three distinct modes of legitimacy. In monarchies, the ruler gained legitimacy through the popular perception that he possessed "divine right" of ruling over a people and/or a territory. In a similar vein, nationalism as a source of legitimacy stemmed from the "devotion to the interests or culture of one's nation" (Lee, 2007: 54). Thirdly, ideology as a source of legitimacy looked to a well-defined set of doctrines and beliefs to form the basis of a political, economic, or social system (ibid). Independent African countries, however, have been known to lack the Weberian modes of political legitimacy. As Englebert (2000) notes, the majority of contemporary African states are exogenous institutions superimposed over pre-existing political structures and inherited by domestic Westernized elites at independence. The only reason why the political borders of this region are where as they are today, is because of external influences predominantly from Europe that drew artificial boundaries arbitrarily around territories on the continent for their own mercantilist agendas. The new African states that emerged after World War II were not endogenous creations of local history and are not embedded in domestic power relations. Thus they lacked legitimacy (i.e. were illegitimate). 
To be "illegitimate", Englebert (2000) argues that states must have all of the following characteristics: they were colonized; they had human settlement before colonization that was not reduced to insignificance or assimilated under colonialism; they did not re-create a pre-colonial sovereignty through gaining independence and after independence, they did severe violence to existing institutions. The foundations of political authority in independent African states bore little resemblance to those in precolonial societies and rarely either had the colonial state borne any relation to the economic systems, political organizations, and networks of social identification of the indigenous people. Furthermore, preparation for independence was never an objective of the colonial state (Englebert, 2000: 77). This research argues that there were varying levels in which African countries were affected by colonialism and disruption of internal governing institutions. It argues that African countries were not uniformly colonized and did not all experience the same degree of violence to existing institutions. Hence, it hypothesizes that some countries like Botswana may have been affected to a lesser extent than other countries in Africa and as a result, experience higher levels of legitimacy. This higher level of legitimacy and lack of disruption (i.e. continuity), would thus be a source of institutional quality in Botswana.

\section{CONTINUITY AND THE FOUNDATIONS OF LEGITIMACY IN BOTSWANA}

This section will explore the evolution of institutions in Botswana and explore how they achieved a relative level of legitimacy and continuity that other resource-rich countries in Africa and beyond failed to foster. It analyzes the Tswana state in three distinct phases: pre-colonial, colonial and post-colonial, emphasizing key aspects at 
points of transition that facilitated continuity of pre-existing institutions. It will also address the evolution of political practices during times of transition, and evaluate the extent to which new institutions gained legitimacy.

\section{Pre-Colonial Botswana}

\section{Early Political Organization}

The first forms of collective organization in Botswana can be traced back to era of the Bantu ${ }^{14}$ migration from the northwest part of the African continent, which accounts for the existence of blacks of Bantu ancestry in contemporary Botswana. Accounts by Tlou and Campbell (1984) assert that the Bantu people first settled in the Transvaal region of modern South Africa, building villages of an estimated hundred huts. Modern day BaTswana are generally regarded as the western group of the Sotho people, who had settled in Transvaal by the middle of the $11^{\text {th }}$ century. The first to arrive were probably the group known today as the Kgalagadi ${ }^{15}$. During the $16^{\text {th }}$ century to the early $19^{\text {th }}$ century divisions of the groups began occurring, beginning with the BaKwena, and later the $\mathrm{Kaa}^{16}$ breaking away from the BaRolong. In 1769 , the BaKwena lived in three separate villages. The BaNgwato, who occupied one village were the first to break away,

\footnotetext{
${ }^{14}$ The term "Bantu" refers to a group of over 400 closely related languages spoken in central, east-central, and southern Africa, belonging to the South Central subgroup of the Niger-Congo language family and including Swahili, Kinyarwanda, Kirundi, Zulu, and Xhosa. It also refers to the people and identity groups who speak these languages. Also referred to as Niger-Congo B, Bantu is particularly distinct from NigerCongo A, Nilo-Saharan, Khoi-San, Afro-asiatic and Austronesian language groupings.

${ }^{15}$ Contemporary minority group not considered Tswana. Chapter 5 will address ethnicity and tribal politics in greater detail.

${ }^{16}$ Contemporary minority group not considered Tswana
} 
followed by the BaNgwaketse. The BaHurutshe ${ }^{17}$ at Shoshong moved northwest to the Botetu River and the BaLete fled to Mosi on the end to the Makgadagadi. In 1795, the BaNgwato split again and a large group under BaTawana went first. Thus emerged a number of groups, each numbering perhaps ten to twenty thousand moving long distances to settle areas sparsely populated in the past. These groups would provide the backbone of the eight Tswana major tribes that are recognized today: BaKwena, BaTlokwa, BaRolong, BaNgwato, BaNgwaketse, BaTawana, BaLete and Bakgatla (Tlou and Campbell: 1984: 233); a situation that will be analyzed in greater depth in this dissertation's fifth chapter.

Pre-colonial Tswana political organization was a highly centralized and hierarchical (Samatar, 1999). The center of authority in the BaTswana nations (the morafe) was the chief (kgosi). The link between royalty, particularly the king and the population was cemented materially through the circulation of resources, particularly cattle. According to Olufemi (2003) the chief had the power to discharge major political, social, religious, and economic responsibilities or to delegate these duties to trusted subordinates. These duties gave him ultimate responsibility for administering important aspects of daily life, especially allocating land, assigning ownership of stray cattle, mobilizing local people for communal labor and warfare, and controlling religious rites.

In recognition of these important social, political, economic and religious roles, local people paid tribute in the form of cattle, ivory, skins, corn and labor. In times of famine, the chief had to redistribute resources among his subjects. Furthermore, the chief

${ }^{17}$ Contemporary minority group not considered Tswana 
could lend cattle out to trusted subjects in need. Cattle were a principal form of wealth and the kgosi controlled or owned large herds. The king used his herd or patronage to bind to him clients whom he depended on for support, a system which helped him foster legitimacy. He loaned cattle to those clients who were supposed to care for it and use their products. As trusted advisors, councilors assisted the ruler in forum-making policies, allocating land and introducing new laws, as well as accepting important religious duties that had critical social implications for the community, notably those of rain-making, ploughing and harvesting (Tlou and Campbell, 1984).

One key chiefly function was to preside over the kgotla. According to Morton, Ramsay and Mgadla (2008) the kgotla was, and continues to be, the basic sociopolitical unit within traditional Tswana society. The word refers to the enclosures that serve as the loci for participatory decision-making and public legitimization of decisions. DiKgotla exist and operate at all levels of Tswana society, from the family unit to larger lineage and ward groupings, to the central kgotla of the morafe, which was presided over by the paramount Kgosi. The word is often used to identify the membership and location of a given kgotla. Kgotla may also refer to other collective organizations and institutions such as political parties, civic groups, social societies and even the National Assembly. The kgotla has continued to symbolize the epitome of Tswana democracy.

Traditional legitimacy, according to Crowder, Parson and Parsons (1990) was a key principle of succession in pre-colonial Botswana. The BaNgwato dynasty emerged as a survivor of the Mfecane, a series of wars and forced migration instigated by the powerful Zulu warrior Shaka. The dynasty thus expanded its authority and subordinated 
neighboring peoples of diverse cultures under its rule. Under the rule of Chief Sekgoma I, the Ngwato chiefdom achieved sovereignty as a kingdom over east-central Botswana. Succession in pre-colonial times was based on primogeniture, whereby the males of the royal family were ranked in order of their genealogical proximity to the incumbent ruler. The kgosi was succeeded by the eldest son of the senior wife, or if he had no son, by his immediate younger brother. This reflected the pattern of succession to more junior offices such as that of the headman as was the pattern of inheritance within each family. With the exception of matrilineal cultures like the Wayeyi (more in Chapter 5), women played only a supporting or advisory role in pre-colonial society.

Crowder et al (1990) studied the succession rules in Tswana societies and interconnected them with the succession procedures in modern democratic Botswana and observed that instances of succession in Botswana politics significantly involved the principles of traditional and rational-legal authority (Crowder, Parson and Parsons, 1990:2) The key succession principle was based on male primogeniture (ibid: 3). In addition, two systems of marriage, sororate and levirate, ensured there would always be an heir (Tlou, 1998). Sororate marriages involve a man's conjugal rights being extended to his wife's sister usually in the event of the wife's death, whereas levirate marriages involve the brother of a deceased man being obliged to marry his brother's widow in order to perpetuate his legacy. This ensured that the chief was inescapably male and hereditary.

According to Mgadla (1998), paramount chiefs could not be nominated, elected or appointed. Instead, an old Setswana adage distinctly states- "kgosi ke kgosi ka a 
tswetswe” meaning "a chief is a chief by right of birth" (Mgadla 1998:3). To limit contestation for political office, a marriage system based on the "great wife" (mohumagadi) was established. According to this system, heirship was determined by virtue of the mother's seniority as opposed to the son's age or order of birth. Wifely seniority was not necessarily based on chronology of marriage either (Tlou, 1972).

This analysis set the stage for what was Botswana's political organization and the protocols that involved changes in power though rules of succession. It shows the embeddedness of the chieftaincy institution in Botswana's culture and society with distinct rules on how leaders emerged. With the exception of assassination, secession or failure to produce a male heir, these rules persisted. However heirship was negotiated through extending eligibility to those who could produce heirs through sororate and levirate marriages. This shows some levels of negotiability in the set rules of Botswana's pre-colonial institutions. However, generally, BaTswana were willing to follow clear protocol and rarely resorted to violence to stake a claim to chieftancy. However, early pre-colonial Botswana showed that the rule of chiefly succession offered very little legitimacy to commoners, foreigners and outsiders. The following section examines the later part of the pre-colonial period and how legitimacy was challenged then.

\section{Later Political Organization}

The $19^{\text {th }}$ century heralded a period of great change to Tswana polities, providing for the first time major challenges to the views of BaTswana of legitimate authority. In 1818, Shaka succeeded Dingiswayo as leader of the Zulus (a major tribe in contemporary 
South Africa) making them a strong military force in the entire southern African region. The Zulus launched raids and caused havoc across the region, a situation known as the Mfecane, which further shaped the political organization of present day Botswana. This event greatly reconfigured Tswana tribal and identity groupings, empowering some, e.g. BaKwena led by Sechele, while marginalizing others, e.g. BaKgadagadi (more detail will be given in Chapter 5). During the 1850s the Boers (the descents of Dutch settlers) attempted to extend their government over Botswana by excluding the British, and particularly the missionaries. In 1852, 400 Boers attacked Tswana Chief Sechele's land and took women, children, and cattle. Sechele realized the ease with which the Boers could take over. The Transvaal Boers had a system of simple expansion and soon the Boer border moved steadily west along the Molopo River and south into the land of the Tlhaping, Rolong and Griquas (all in modern Botswana). The interference of the Boers was the first major challenge to chiefly autonomy and power for the Tswana chiefs.

By 1870 the Tswana appealed to the British for support, who eventually agreed to arbitrate, but the Tswana regained little of their lost land. In 1875 Chief Gasenone of the Tlhaping agreed to cede his and other lands to the Transvaal Boers. The British annexed the Transvsaal in 1877. In 1878, the Tswana south of the Molopo River revolted: a situation which focused British attention on the situation and a representative, Sir Charles Warrant, was sent to hear the complaints and grievances of the Tswana. John Mackenzie, a missionary at Shoshong, also intervened and became a close friend and confidant of Khama III of the Ngwato. In 1881 a compromise was reached with the British Commission and a line was drawn to include the Transvaal lands actually occupied by 
Boers. It excluded that which they claimed but had not farmed. The Pretoria Convention, the peace treaty that ended the First Boer war, was signed in August of the same year, giving the Transvaal to the Boers. Sir Charles Warren went north with a strong force and the Boers were put off the land and order restored without a single shot being fired. In March of 1885, a protectorate was declared. The protectorate included the entire area north of the Cape Colony, west of the South African Republic, east of longitude $20^{\circ}$ and south of Latitude $22^{\circ}$. The area south of the Molopo River was declared a British Crown colony, named "Bechuanaland" and the north, excluding "Khama's country" was declared a British protectorate. The colony was to be administered by Britain, but with the exception of the police, the Protectorate was not. The headquarters for the protectorate was located in Vryburg. In May 1892, an order-in-council said that administration could be introduced to the protectorate as long as native law and custom were respected. Thus what was called a protectorate became in fact a colony. On $15^{\text {th }}$ November 1895, British Bechuanaland became part of the colony of the Cape of Good Hope and the area to the North remained a protectorate (Beaulier, 2003).

The pre-colonial period illuminates the foundation of Tswana customs and practices deemed legitimate by the polity. However, the later period was a period of chaos causing much chagrin among Tswana communities as a challenge to the state of their autonomy. The first threat to institutional continuity was posed by the Boers in the Boer-Tswana invasion. However, the appeal by the Tswana chiefs for British protection, inadvertently saved BaTswana from a much greater threat to their institutions. The 
following section details the character of colonial Bechuanaland within the context of institutional continuity.

\section{Colonial Bechuanaland}

The establishment of a German colony in Southwest Africa (modern day Namibia) and the Boer expansion led to the declaration of the Bechuanaland Protectorate (BP). As a result, the protectorate was declared mainly in response to the international situation as opposed to internal circumstances. The protectorate was of strategic importance within the context of its geostrategic positioning in southern Africa. In response to a Boer invasion, three chiefs Sechele (Kwena), Bathoen (Ngwaketse) and Khama (Ngwato) travelled to London to request for safeguard against the Boers and thus readily accepted the protectorate idea. At this time, no sub-soil minerals had yet been found and Botswana was mainly an agrarian society that was highly dependent on its cattle wealth. This lack of importance placed on Botswana enabled it to experience a type of colonialism that was not as harsh as in other parts of the continent and the British did not bother consolidating its own institutions in Botswana.

In the British colonial system, a protectorate was a territory under the Crown that was regarded as not being strictly British territory or part of its dominions (i.e. used for white settlement, such as Canada and South Africa). In theory, a protectorate was created through a treaty with indigenous authorities. In the case of Botswana, it was established in the wake of the Warren Expedition, whereby the British army alleged it had gained the consent of diKgosi in southern Botswana for the establishment of Great Britain's 
authority over the territory north of the Molopo River. British authority over such territory was made official by the Foreign Jurisdictional Act of 1890 [Morton, Ramsay and Mgadla (2008)]. Morton et al (2008) argue that the advantage of the "protectorate" concept was that the British Crown could claim in Parliament that most of the administration of such a territory, and by extension its expense, remained the responsibility of indigenous authorities, whereas the territory belonged to the British sphere, thereby disallowing claims of rival European powers. Therefore, technically Bechuanaland remained a largely autonomous territory that was protected diplomatically or militarily against third parties by a stronger state or entity. This provided Botswana the best of both world: protection from external threats that could potentially disrupt its institutions, and survival of internal institutions.

After the Boer War (1899-1902), Britain intended Bechuanaland for incorporation into the Union of South Africa. Protectorate status provided no protection as such to Bechuanaland's African inhabitants, who were taxed, systematically subjected to racially based exclusion, deprived of much of their arable land, and reduced to dependency for cash on labor migration. The economic basis of their status derived from the fact that Great Britain and the Union of South Africa regarded Bechuanaland as unsuitable for mining or ranching.

Different scholars' classification of the British colonialism in Bechuanaland vary from "light rule" (Acemoglu et al. 2001, p. 13) to "benign neglect" (Beaulier 2003:229). The British admitted to limited interest in the Bechuanaland Protectorate arguing that: 
"We have no interest in the country to the north of the Molope [Bechuanaland], except as a road to the interior; we might therefore confine ourselves for the present to preventing that part of the Protectorate being occupied either by filibusters or foreign powers doing as little in the way of administration or settlement as possible." (1885 British Commissioner's statement quoted in Acemoglu et al. 2001: 13)

According to Seidler (2010: 16) British rule was characterized by a number of factors. Firstly, the colonial administration was nominal and characterized by a limited degree of interaction between the administration and the indigenous populations. The administration's sphere of influence was thus restricted to the colonial capital, stationed physically outside the Protectorate. Furthermore, chiefs retained their judicial, legislative and executive powers, but worked with the colonial district commissioners as intermediaries between the administration and the local population. Thirdly, minority groups such as European and Asian populations had direct contact with colonial authorities while the Tswana population maintained their institutional settings. Finally, limited interest was shown in Botswana's natural resources and inadequate investment in infrastructure resulted. A huge bulk of British spending was on administrative expenses and the army.

With the imposition of British rule, Tswana rulers and their people struck a delicate balance between old and new forces. As the custodian of cherished local values and the ultimate expression of communal aspiration, chiefs emerged as the primary agents of governance and stability in Bechuanaland during the colonial period. This development was an important context for the imposition of colonial rule on Tswana 
society. The interaction between the regional and the local contexts evolved the indirect rule system as Tswana society encountered rapid social change in the latter years of colonial rule. With the incorporation of Tswana society as a British protectorate in 1885 , the institution of chiefship revolved around a three-tier colonial administrative system consisting of the high commissioner based in Cape Town South Africa, the resident commissioner stationed in Mafikeng South Africa, and the eight Tswana chiefs. As the European administrator on the ground, the resident commissioner served as the critical link between the chiefs and senior administrators in Cape Town.

In the immediate years following the establishment of colonial rule, chiefs, subchiefs and headmen had primary responsibility for tax collection, for providing labor for colonial projects and for promoting British economic interests. As an incentive for aggressive tax collection, chiefs retained ten percent of the overall tax proceeds. British colonial authorities thus essentially, according to Olufemi (2003), administered Bechuanaland through a strategy of local administration that sought to control the eight Tswana subgroups and their immediate neighbors through the prevailing indigenous sociopolitical structures. However, the imposition of protectorate status over Tswana states led to a limited erosion of the institution of chieftainship and set in motion an increasingly centralized structure. While conceding a substantial autonomous space to the Tswana chiefs, colonial officers conferred them with important administrative obligations. The first decade of Bechuanaland incorporation saw British administrators performing minimal supervision over local administrators. This resulted in the traditional leaders preserving significant control over their local polities, adjudicating law and 
maintaining order as had always been the case (Olufemi, 2003). Although there was the inevitable evolution in power structures occasioned by colonialism, this did not upset existing institutions, thus helping them endure colonialism.

Before the end of the nineteenth century, most of the Tswana chiefs converted to monogamy and Christianity. Prior to this, polygyny had complicated succession via male primogeniture. The successor was the first born of the wife recognized by the morafe as the mohumagadi, a designation not necessarily a result of the chronology of the marriage. The mohumagadi could in fact be the second or third woman to be married by the kgosi, but in genealogical terms her house was the first house of the husband because of the prestige of her own paternal genealogy (Crowder, Parson and Parsons, 1990. However, once chiefs adopted Christianity as the state religion - as Khama III did in 1875 - the major dispute was eliminated because the rulers became monogamous. Crowder et al (1990) account for the 1925 claims to the Ngwato throne made by Gasethsware, son of Sekgoma II by Mary, the sister of the second wife Serero, which were rejected on the grounds that he was illegitimate in Christian and in traditional terms, Mary had not married Sekgoma, either in a Christian or in a traditional ceremony. Gasethsware's claim, was rejected even in traditional terms on the grounds that, though a barren wife could bring in a sister to bear children on her husband's behalf, as a seantlo (inherited wife), Mary had not been recognized in this capacity and therefore was no more than a concubine whose sons could never succeed. After Christianity there was little doubt as to the reigning monarch's successor as there was with the European monarchies that practiced male primogeniture: 
"Kgosi ke kgosi ka a tsetwe" (A chief is chief because he is born to it). Setswana proverb

Even in pre-Christian times, when the polygyny practiced by the Tswana rulers could lead to claims and counter-claims as to the legitimate successor, the power struggle took place within the royal family. There were no instances of a commoner attempting to usurp the chieftaincy or claim the throne.

Tswana institutions, according to Siedler (2012), were not directly challenged by colonial rule. It did not forcibly replace local institutions with colonial ones and as a result, there was no direct struggle between Tswana cultural norms and British formal institutions. However, they did have an important impact via the introduction of colonial taxation systems, the subsequent job migration to European and South African owned mining interests, the intense contact with missionaries, and the accumulation of wealth by Tswana elites. The institution of taxation, hut tax (1899) and native tax (1919) strengthened the political and economic power of chiefs, who received a 10 percent commission. It provided a structural change in Bechuanaland, as for the first time, it introduced a cash-based economy as opposed to a barter trade economy. Adult males found themselves in need to enter the job market in order to pay taxes, a situation which would later lead to a massive exodus to work in South African mines. The Tswana polity peacefully accepted the institution of taxation, unlike in Sierra Leone where Britain's imposition of the tax sparked off two rebellions in the hinterland (Killson, 1966). This was probably because pre-colonial institutions accepted the payment of tribute to chiefs, 
so the payment of taxes was not an entirely foreign concept; it just altered the medium of exchange from cattle and other resources to money.

One key aspect that could potentially affect historical precedent and legitimacy however, was the rules of chiefly succession. It is key to note however, that although in pre-colonial Botswana the rules of succession were set in stone, the practice of succession during the colonial period in Botswana was replete with anomalies. Tshekedi Khama became the BaNgwato regent in 1926, after his brother Sekgoma II died after serving only two years of chieftaincy. The heir to the throne, four-year-old Seretse Khama, was deemed not ready for the job of ruling the BaNgwato, and as a result, his 21-year-old uncle Tshekedi Khama became regent. This is but one instance of succession where male primogeniture was not exercised but still, the presiding chief overwhelmingly gained legitimacy from the population. The introduction of Christianity by missionaries made sororate and levirate marriages implausible, a change that was deemed legitimate overwhelmingly by BaTswana. These incidences demonstrate that in Botswana, as long as the change was voluntarily put in place without any external coercion, legitimacy was to some extent negotiable, a situation that helped facilitate the transition from colonial to post-colonial governance, which will be discussed in the ensuing section.

In summary, as in most parts of Africa, within the context of continuity and legitimacy, the colonial government in Bechuanaland faced the task of obtaining the obedience of the people particularly as it presented a period of potentially intensive institutional transformation. In other parts of Africa, colonialism generally provided a "natural experiment" in which foreign institutions were imposed on existing and 
predominantly informal institutions of the local population (Sielder, 2011:2). However, in Bechuanaland, through the exercise of indirect rule, chiefs retained their judicial, legislative and executive powers while working with the colonial district commissioners as intermediaries between the administration and the local population. This situation was deemed more legitimate to the population. Although Botswana citizens generally viewed the colonial government as external and illegitimate, the colonial government's benign neglect of Bechuanaland facilitated for the continuity of Tswana institutions. The colonial government coopted traditional rulers through a system of indirect rule in order for its authority to gain acceptance, and legitimacy, a situation which inadvertently enabled the smooth adoption of British institutions in post-colonial Botswana. The following section will detail how Botswana managed to remain stable in the postindependence period while adopting foreign institutions in a peaceful manner, all the while retaining institutional autonomy.

\section{Independence and Post-Colonial Botswana}

\section{Background to Independence}

The Independence movement in Botswana revolved around the life of its central figure, Seretse Khama. The son of Sekgoma Khama II, the BaNgwato paramount ruler and grandson of Khama III (one of the three chiefs who negotiated the protectorate) Seretse was of royal blood. His name, which means "the clay that binds together," was conferred to him in celebration of the reconciliation of his father and grandfather who had been estranged. This reconciliation assured his own ascension to the chieftaincy upon his 
father's death on 1925 (Mgadla, 2000). As mentioned above, Seretse became $\mathrm{kgosi}$ at age four, with his uncle Tshekedi Khama performing the role of his regent and guardian. He attended Fort Hare University in South Africa and later Balilol College of Oxford, and before returning to Bechuanaland, had married a white English clerk. His choice of bride proved controversial both to the conservative Tswana and to the South African apartheid regime, which in 1951 put in place an inquiry to remove his chieftaincy title. He would later renounce his chieftaincy title in 1956, return to Bechuanaland with his wife, and attempt a life as a cattle rancher before venturing into local and then national politics.

In 1964, Britain accepted proposals for democratic self-government in Botswana and the seat of government was officially relocated from Mafikeng, South Africa to Gaborone. According to Middleton (1997) the flow of South African exiles into Bechuanaland provoked the formation of the Bechuanaland People's Party (BPP) by Kgaleman Tumedisho Motsete, Phillip P. Goanwe Matante and Motsomai Mpho. Matante and Mpho had both worked in South Africa's mining industry and had participated respectively in the Pan Africanist Congress and the African National Congress parties there. Under Matante and Mpho's leadership, the BPP mobilized a newly urban migrant worker constituency along the north-south line of the rail and held demonstrations demanding immediate independence and a socialist transformation, an ideology inspired by their South African political counterparts. The BPP, however, split in 1962 when Mpho left to form the Botswana Independence Party (BIP) and again in 1964 when Matante and Motsete led respective factions into the 1965 elections. 
Perceiving the radical leftist threat in BPP, Seretse Khama joined together elements of the cattle-owning, rural-based, royalty-related leadership elite with a growing member of educated elites to form a political party. In 1961 Khama founded the nationalist Bechuanaland Democratic Party (later Botswana Democratic Party (BDP). The BDP mobilized a rural constituency whose households relied mainly on a combination of subsistence agriculture and remittances of wages from family employed in South African mines. Household subsistence depended heavily on access to the use of oxen. To a significant extent, since most households did not directly own oxen, access depended upon a relationship to those who did. The cattle owners tended to have inherited political position and to be leaders of the BDP, particular in places where its support was greatest. The BDP was therefore a relatively moderate, even conservative, movement desiring independence but not a radical transformation to existing labor relations (Middleton, 1997). As a result, BDP moderation appealed to the Tswana people as it provided an alternative with more legitimate continuity than would otherwise be availed by the opposition parties which had external sources of inspiration that the native BaTswana did not relate to.

Botswana's first multiparty elections were held in March 1965. The BDP won 28 of 31 seats in the legislative assembly and 80.4 percent of the votes cast, a figure that greatly reflects the fact that the general population identified with the mandate of the party. Local government elections, won by the BDP, were held in 1966, by which time the political party that was to become the leading opposition, the Botswana National Front, founded by Kenneth Koma, had come into existence. 
As Prime minister, Khama pursued the push for independence and was a key architect of the 1965 constitution that delineated a new government in Botswana. Upon independence in 1966, he was elected president. His first term was marred by dismal prospect of economic success as the arid country was among the world's poorest. However, Seretse set out on an enthusiastic course to transform the economy into one that was export-based, built around beef, copper, and later diamonds, which were discovered in 1967. Between 1967 and 1980, Botswana maintained the highest rate of economic growth in the world, with much of the diamond revenue being reinvested into infrastructure, health and educational programs. Khama is credited as having put in place strong measures against corruption, lowering taxes, liberalizing trade and increasing personal freedoms.

\section{Institutional Continuity in Post-Colonial Botswana}

Decolonization represented another landmark in the transformation of Botswana traditional institutions of governance. African nationalist leaders pursued policies to Africanize the post-colonial bureaucracy without indigenizing the institutions of modern governance. What facilitated the survival of pre-colonial institutions in Botswana was, according to Gillett (1973), the demographics of the electors, who were largely illiterate peasants, holding the legitimacy of chieftaincy in high esteem. Thus the Botswana Democratic Party (BDP)'s hold on power since independence in 1966 has greatly depended on the passive approval of chiefs. In addition, the BDP were able to co-opt the support of industry leaders, cattle ranchers, academic elites and others to form a "grand coalition" (Sebudubudu and Molutsi, 2009: 1). The relatively high level of continuity 
between pre-colonial, colonial and post-colonial institutions is reflective of Botswana's high level of vertical legitimacy (Englebert, 2000:158).

According to Parson et al. (1990) the new national state had a degree of constitutional legitimacy, derived from internal sources, which were inherently greater than those of the colonial regime. The latter was essentially an arbitrary imposition from external sources of legitimacy. The introduction of the republican constitution at independence raised the question of acceptance of the new authority system by both the Tswana population at large, and office holders, both traditional and elected. The competing bases for popular loyalties raised questions about the ability of the national government to command the automatic obedience and support of the population. In the short run, this issue was clouded because Seretse Khama was not only the first president, but simultaneously was the traditionally legitimate chief, facilitating a smoother transition. The succession question was kept open until 1980. Whether a "commoner" constitutionally succeeding to the office of president could command the obedience of the population was problematic, and some thought the BDP would de facto have to rely on the chiefs or on coercion for the command of that obedience. However, upon independence constitutional changes in the direction of an independent Botswana never raised any serious doubt about the fact that the new national government would be one based on elective office holders organized via political parties. It was apparent early on that the authority of the post-colonial government would take precedence over royal authority. 
At independence representative national and local governments based on liberal and democratic principles, were the only alternatives seriously considered by Tswana elites. A national assembly composed of single member districts of roughly equal population size and a universal adult franchise electing those members emerged as the rules for selection to hold national legislative office. Botswana's democratic system echoes its status as a former protectorate of the British Empire while maintaining a strong element of traditional sources of authority. The country espoused a Westminster Parliamentary system with a unicameral assembly responsible for the country's legislation. It preserved traditional governance through establishing the House of Chiefs (Ntlo ya DiKgosi) which served an advisory role to the president and parliament (Parson 1984).

Botswana's transition to a liberal legal tradition did not eliminate traditional and customary law. The country relied heavily on tradition, and the legitimacy of Botswana's political system stems from its traditional sources. Prior to British rule, Botswana developed a proto-democracy where chiefs held the position of first among equals. His power had checks and balances from the polity, and this tradition was carried out through Khama's presidency, enhancing the legitimacy of the political system (ibid). The following section analyzes Botswana's sources of institutional quality and legitimacy using the Weberian understanding of authority. 


\section{SOURCES OF LEGITIMACY IN BOTSWANA}

\section{Three Sources of Legitimacy}

The central argument of this chapter follows the criteria provided by Weber and Englebert in determining Botswana's relative levels of legitimacy as having explanatory value in accounting for Botswana's institutional success in the face of diamond wealth. Three key historical aspects of the Botswana experience are seen as having the most effect of ascertaining the legitimacy of Botswana's institutions. These three are, institutional continuity, ethnic homogeneity, and post-colonial political leadership, all of which are historical, and all of which enabled it to create quality institutions.

One major source of legitimacy was "legitimacy through institutional continuity", through limited colonial engagement as was already been explained in great depth above. Unlike most other African countries which were crown colonies or settler colonies, Botswana was merely a protectorate of the British Empire. This enabled traditional authority in Botswana to thrive and as a result, contemporary Tswana society sees a high level of continuity between its pre and post-colonial institutions.

A second source of Botswana's legitimacy was "legitimacy through ethnic homogeneity and sense of homeland ${ }^{18}$." Ethnic heterogeneity has long been seen as a reason why countries fail to build up the norms of trust that are needed to develop quality institutions. Easterly and Levine (1997) argue that ethnic heterogeneity's adverse effect on the political economy stems from "wars of attrition" that take place between ethnic groups. Ethnic groups are subject to competition as each ethnic group over-extracts from

\footnotetext{
${ }^{18}$ Ethnic homogeneity as a separate hypothesis will be addressed in Chapter 5 of this dissertation.
} 
a common resource like commodity export rents. In addition, ethnic groups may have difficulty agreeing on the type of public goods, leading to less total spending on public goods. Ross (1999) attributes ethnic heterogeneity as providing the means in which grievance-based political rebellion is justified. In authoritarian states, ethnicity has been used as a mechanism for rulers to obtain patronage from their "own". As will be detailed in Chapter 5, no such motives were present due to its relatively high level of ethnic homogeneity. As a result, resources were developed without the externalities that ethnic heterogeneity brought in other countries.

As mentioned earlier, during colonialism, there was a high level of arbitrariness in the drawing of political boundaries around African states that resulted in low levels of vertical legitimacy. In the case of Botswana, however, the level of arbitrariness was low, enabling the state to establish horizontal legitimacy. Englebert (2000) defines horizontal legitimacy as the extent to which there is agreement to what constitutes the polity or the community that comprises the state. In other words, whereas vertical legitimacy may refer to the presence of a consensus on the content of the social contract, horizontal legitimacy implies an agreement about who participates on the contract negotiations. As a result, it establishes a link between the population and the territory of a state.

Non-Tswana tribes gradually became subject to Tswana authority who presided over specific indigenous territories. It was the goal of the Tswana to integrate, absorb and assimilate other groups within their institutional structures. As a result, cultural dominance of the Tswana tribes and the diffusion of their rules and norms occurred. Botswana was fortunate to not have endured the divide-and-conquer strategies that 
Belgium, Britain and France had pursued in other parts of Africa as a mechanism to secure control over their colonial territories. However, Botswana's laws allow for discrimination on the basis of language, ethnicity and culture. In a bid to create a monoethnic state, the goal of post-independence Tswana elites was to assimilate all identity groups into the Tswana culture. This assimilation policy was codified in the country's laws, specifically:

Sections 77 to 79 of the Botswana Constitution which gives chiefly powers only to the eight principle tribes of Botswana;

Section 15 (4) (d) and 15 (9) of the Constitution, which while providing for the right to non-discrimination based on ethnicity, fails to protect the rights and freedoms of tribes as collective entities;

Section 2 of the Chieftainship Act, which also defined the term tribe and confined it to mean the eight Tswana-speaking tribes to the exclusion of the other tribes represented in the country. It further defined the term chief to mean the chiefs of the eight Tswana-speaking tribes to the exclusion of the chiefs of other ethnic groups and;

The Tribal Territories Act, which placed the custodianship of the land under the governance of the 8 Tswana tribes ${ }^{19}$.

The third source of legitimacy I isolated was "legitimacy of initial political leadership" particularly at a pivotal point in resource development. In Botswana's case,

\footnotetext{
${ }^{19}$ And as a side note, I know a lot of agitation has been expressed against these assimilation laws particularly where the Basarwa peoples are concerned, but that is outside the scope of my analysis at this point. This research addresses ethnicity and identity as a separate hypothesis to the greater question of the research in Chapter 5
} 
this was the discovery of its diamond wealth. I argue that Khama gained legitimacy firstly from his biological link to the traditional governance structures if Botswana, which gave him credibility especially among his rural electorate. This organic link gave him credibility, as well as fostered a personal commitment, to the economic growth of his country facilitated by his inherent duty as chiefly custodian of resources and designator of responsibilities. These circumstances led to the preexisting Tswana hegemony within the new structures of post-colonial statehood.

\section{Succession and Challenges to Legitimacy in Botswana}

The legitimacy of a ruler faces many challenges. Usually these challenges are confronted at the point of change of power from one ruler to another. If the populace does not believe in the legitimacy of the ruler, succession may lead to coup d'état or civil war. However, if they believe the rule and mode of succession is legitimate, then democracy can be consolidated faster. This section will look at varying points of succession in Botswana and how they resulted in the perpetuation of authoritative legitimacy in Botswana.

The point of succession is a critical event in the preservation and continuity of any political system. According to Parson et al (1990), it demonstrates the extent to which a population accepts the right of rulers to rule and therefore the degree to which automatic obedience directly follows. As a result, succession yields important insights into the sources of stable rule. Thus, every succession is in a sense a fundamental challenge to the 
legitimacy of a system. The case of Botswana is surprisingly characterized by the relatively smooth succession of individuals in positions of authority (Parson et al 1990).

As noted above, for Weber, legitimate authority derived from one of three ideal types: traditional, charismatic and legal-rational. Each type was based on the acceptance of one or another organizing principle: time honored descent in the case of traditional authority, a magnetizing or mesmerizing personality in the case of charismatic authority, or acceptance of a set of rulers in the case of legal-rational authority. The persistence of popular obedience to any person in authority stemmed from adherence to one or another of these organizing principles and as long as that principle prevailed, so too did the authority of the rulers over the ruled (Wallis and North, 2011).

In pre-colonial Botswana traditional legitimacy based on male primogeniture was a key principle of succession. To a large extent, it was strengthened as a form of resistance to colonial rule. During the colonial period, the British had attempted to assert its overriding legal authority, ultimately based upon its command of coercive armed force. However as Parson et al (1990) contends, the acceptance of that authority continued to depend upon its cooption of traditional rulers in the system of colonial (indirect) rule. The tension between the pre-colonial and the colonial systems provided a particular texture, with obstinate chiefs refusing to relinquish their power to suit colonial officers. Candidates for chiefdom favored by the colonial administration could not be installed at will. As a result, chiefly non-compliance undermined colonial policy to a degree rare elsewhere in colonial Africa. 
Sovereign Botswana was a state created on the basis of a legal rational set of constitutional rules, within political institutions, powers and procedures defined clearly in the constitution of the Republic. The constitution's rules on succession were fixed but contradicted with the traditional rules of succession to high office. Generally the president would be elected by a majority of elected members of the national assembly and premised on the principle of representative government. As opposed to being naturally born heir, to become president in Botswana one had to be a citizen, at least 21 years of age, a registered voter and succinctly fluent in English. The process of succession would occur in the form of election which would take place whenever the office was vacant or when parliament dissolved, a process that usually took five years. This new system directly contradicted the traditional system, as the principles based upon each system were mutually exclusive. So how did Botswana manage to transition from the traditional sources of legitimacy to legal-rational legitimacy based on constitutional rules?

This dissertation argues that the new national state had a degree of constitutional legitimacy derived from internal sources. The population never internalized the colonial government as their own but they welcomed a fellow Motswana representing them, albeit in a foreign system. The introduction of the republican constitution raised questions of acceptance of the new authority system both by the population at large and by the office holders- traditional and elected. What helped facilitate the smooth transition was that unlike in monarchies like Swaziland and Lesotho, Botswana did not have a nominal paramount chief in its territory. A large portion of the land was now controlled by the 
state and not by chiefs and none of the chiefs could lay claim of authority over another. Furthermore, none of the Tswana tribes were disproportionately important, whether numerically or strategically, as in other parts of Africa like Uganda with the king of Buganda or the Litunga of the Lozi in Zambia. There was thus no doubt that the authority of the government would be superior to traditional authority and that succession in Botswana of the highest office would be based on elective office-holders organized through political parties. This facilitated for the peaceful acceptance of a "commoner" as president in 1980.

\section{Explaining BDP's Longevity as Legitimacy}

A key feature of the Tswana political landscape even till today has been the longevity of the Botswana Democratic Party (BDP) in power, primarily as a result of the initial foundations of its authority's legitimization. As explained earlier, due to the heirship as paramount chief of the first President Seretse Khama, there was a smooth transition from colonial indirect rule to independence. The current President of Botswana is Ian Khama Seretse Khama's first son, who according to the pre-colonial rules of primogeniture is the rightful paramount chief and appraised heir to the top leadership position in the republic. The middle two presidents Masire and Mogae, in contrast, reflect constitutional legitimacy based on legal-rational authority. According to Parsons (1990), early voter apathy in Botswana (31percent to 51percent turnout averages between 1965 and 1980), could be viewed as a proviso to the initial limited legitimacy of the legalrational framework. However, this dissertation argues that since no challenges led to 
outright violence, this could be viewed as an endorsement of the system, albeit with limited participation.

The Botswana opposition parties for the most part emanated from South African resistance movements, particularly the ANC. Their slogans "Kill the Boer," and other such slogans inspired by the civil rights movements elsewhere in settler southern Africa failed to resonate with the predominantly rural Botswana citizens who had never experienced the injustices of apartheid. The people who launched most opposition parties in Botswana were mine workers who had spent most of their time in apartheid South Africa. Inspired by the liberation plight of black South Africans, they returned home with renewed vigor, attempting to gain political support among Botswana citizens. Their campaigns concentrated on singing liberation songs. However, most Botswana citizens had different priorities of conserving labor relations in Botswana particularly in the dominant cattle industry. They were different from black South Africans, who were fighting against apartheid. The BDP centered its efforts on development and education.

The BDP derives its legitimacy from its inclusive patronage structures which incorporated urban elites, the middle class and the key rural elites - chiefs and cattle owners. Prior to the discovery of diamonds, cattle owners were the most important economic and political interest in Botswana. As a result the BDP is often characterized " $a$ government of cattlemen". This is of key importance, as it created an economic elite group prior to the discovery of diamonds that was based on a separate economic activity - the beef industry. The elite invested heavily in the Botswana Marketing Board (the $\mathrm{BMC})$. 
Another source of legitimacy of the BDP is that it faced constraints though the restriction of distortionary policies. Political accountability of the BDP was enhanced by internal competition within the party manifested through primary elections. These result in a dynamic rotation of elected officials. Two factions emerged within the BDP, a situation which consolidated both accountability and political competition. One faction allied with older party cadres supports more statist policies and the allocation to civil servants in the government of power over resource allocation, while the other groups in supports local community projects providing a counterweight within the BDP. Furthermore the BDP allows for a high level of press freedom resulting in considerable criticism of policies and politicians. The BDP allows opposition parties to compete for and take control of local councils when successful, a situation increasingly occurring in urban areas. All of these factors led to institutionalized checks on both the government and the one-party dominated polity aiding the reduction of anti-developmental corruption often observed in mineral-abundant and centralized state-led economies (Di John, 2009).

By the time diamonds were discovered in Botswana, the country had already developed broad-based political parties and efficient economic institutions of property rights. This assisted in avoiding destabilization caused by rent-seeking. Due to the broad and inclusive coalition of the BDP, incentives to challenge state authority were reduced. This enhanced the capacity of diamond rents to be circulated in the form of infrastructure and social service delivery. Furthermore, Seretse Khama's decision to transfer the property rights over diamonds away from his own tribe, the BaNgwato, to the state, circumvented brewing conflict among Tswana groups over the regulation of diamond 
revenues $^{20}$. In addition, his decision to moderate the political power of tribal chiefs with respect to land allocation just after independence is also seen as having truncated tribal cleavages and conflicts (Di John, 2009).

\section{Insights on the Legitimacy of Authority in Botswana}

The preceding sections explained legitimacy from a historical viewpoint. This section will draw insight into the views of research respondents on their views of the legitimacy of Botswana's economic and political institutions. The overwhelming response was bent towards an understanding of legitimacy through the efficient provision of goods and services by the BDP government using diamond revenues. Another key finding was that in Botswana, legitimacy of institutions was greatly tied to economic performance. On the surface, this may look as though Botswana citizens are deriving legitimacy from economic performance. However, this dissertation is of the view that since the distribution of resources during pre-colonial Botswana was under the custodian of the prevailing governance structures, this expectation of government still existed in Botswana in the post-independence era. As a result, most respondents tied economic success not to diamond discovery, but to the ability of the BDP led-government to distribute these resources.

According to Batlang, a student of political science at the University of Botswana (UB), the majority of Botswana citizens are generally happy with the government because in his view, the government is legitimate and fairly elected. He argues that,

\footnotetext{
${ }^{20}$ More of this analysis of tribal allocations occurs in Chapter 5
} 
although it has been the same government for the past 45 years of independence, the ballot has consistently shown its confidence in and endorsement of the BDP administration. The government has tailored development policies to the citizens. It has advanced its diamond revenue for the betterment of the people. Similarly, Molomo, a professor in the Political Science department at UB asserts that the Botswana government is viewed as legitimate due to its relative success in governance. The Mo Ibrahim Index currently ranks Botswana third on the continent, after Cape Verde and Mauritius. However, this legitimacy is slowly eroding. He insists that in order for a government to remain legitimate, it should be responsive to the needs and grievances of the people. The citizens recently took part in the greatest protest the Botswana Government has ever confronted, wanting salary increments.

According to Molomo, the current BDP government gains its legitimacy from its past performance.

"When you have lived in this country and looked at where we come from, I started my school in 1963 and I know the life that we had then in my home village of Mochudi there were only three vehicles donated by the Kwame Nkrumah Congress People's party and as a young boy to see such a spectacle was amazing. That is just one example. Now there is also running water, tarred roads, [and] tarmac. The only tarmac when we went to school was only $1 \mathrm{~km}$. People were drawing water from rivers. Now when you've lived through this period, you've seen Botswana as a poor country through 1967 when diamonds were introduced, to now with the affluence that we have acquired, it does accord government a lot of legitimacy because in terms of service delivery and in terms 
of bringing people from absolute poverty to where they are, it has done an amazing job. In addition, to create the institutions particularly a bureaucracy has been one of the most efficient civil services Africa has had. The phenomenon of development planning has been central to this process. The plans emerge from the rural development plans and integrated and consolidated into the greater national development plan."

Molomo goes on to assert that Botswana citizens promote diligence and steadfastness and are able to see developmental plans to their fruition, something their neighboring counterparts marvel at.

According to Tsie, another professor of Political Science at the University of Botswana, although civil society is relatively weak, Botswana's society in general has emphasized discipline and community service. He contends that the state-society nexus from pre-colonial times has been very strong because the society looked to the state for protection, particularly when the British came. They looked to the chief not only for security but for sustenance. For example, in times of droughts, grain saved at harvest in granaries was divided among the people. As a result of traditional institutions not being fully eroded during the 70 years of British colonial influence, Botswana managed to maintain this culture. This is unlike in most other countries where chieftaincy and other institutions were abolished and/or disrupted. When BDP came into power they did not abolish chieftainship but harnessed the influence and authority of the traditional leadership to support the administration. As a result, he argues that there is a high correlation and high legitimacy of the state and as a result, very few people challenge the 
authority of the state. Tsie contends, however, that this culture of community has had the paradoxical result of creating a new culture of entitlement and dependency on the state.

According to Marobha of the Independent Electoral Commission of Botswana, legitimacy derived from the fact that to start with the first two parties were led by chiefs and there was a lot of subject loyalty per identity group. And the first presidents' tribal group happened to be the largest group, with other tribally based political parties such as the BNF splintering. The solidarity of the BDP, a BaNgwato stronghold was thus facilitated by the population of the BaNgwato, Botswana's largest tribal group ${ }^{21}$.

According to Gobotswang, a member of the opposition party Botswana Congress Party (BCP), the BDP has historical legitimacy because the party was formed and led by Seretse Khama, who had both traditional as well as charismatic authority. He was able to rally the support of the former colonial government and used his chieftaincy and public service to rally behind the BDP. Lack of political consciousness also helped the BDP during its formation years. Botswana managed to avoid the problems of its surrounding neighbors, and therefore political consciousness of issues of broader political economy was greatly lacking. However, the Botswana citizens understood and appreciated chieftaincy. They accepted that a chief had to lead. This gave them legitimacy. Realizing this, the BNF responded by grasping the Chief of the BaNgwaketse, thus creating a predominantly BNF base in Southern District, the district where BaNgwaketse reside. This popularity was, however, marred by the breakaway and formation of the Botswana Congress Party (BCP). Mismanagement of the party greatly eroded its influence and

\footnotetext{
${ }^{21}$ See Chapter 5 for a breakdown of Botswana's tribal groups and populations.
} 
serious conflicts broke out. As a result, after 1999 BDP was ruling by default, its only formidable challenge having broken apart. The latest election saw seats dividing 52-47 in favor of BDP.

According to Mokhawa, a professor of International Relations at UB, Botswana is a very difficult country to figure out and that has to do a lot with its history in terms of after independence, finding it to be very poor. The commitment of the government then was to try to provide the basic services to people, something the populations viewed in terms of the pre-colonial chieftaincy's traditional commitment to allocating resources. On that basis the citizens where looking to the state to provide goods and services. She asserts that one can say it is evident from the fact that the BDP keeps getting re-voted into power, the legitimacy of the BDP has consistently been underscored by the citizens to demonstrate their confidence in the BDP government and ultimately the state.

She argues that the Botswana population is divided into segments that have a different understanding of legitimacy and the role the government should play. Figure 3.1 shows the rural proportion of Botswana from 1967 to 2013: 
RURAL POPULATION (\% OF TOTAL POPULATION) IN BOT SWANA

The Rural population (\% of total population) in Botswana was last reported at 38.90 in 2010, according to a World Bank report published in 2012. Rural population refers to people living in rural areas as defined by national statistical offices. It is calculated as the difference between total population and urban population. This page includes a historical data chart, news and forecasts for Rural population (\% of total population) in Botswana.

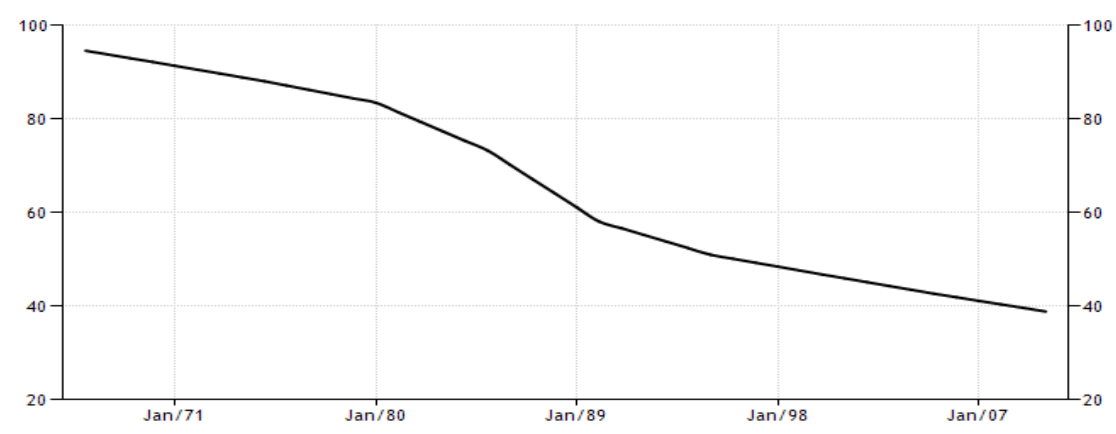

WORLD BANK INDICATORS

\section{Figure 3.1: Proportion of Rural Population 1967 to 2013}

The rural classes who have been consistently loyal to the BDP have greatly been influenced by BDP's past successes and the historical roots of authoritative legitimacy. On the other hand, the new middle class in Gaborone and other urban centers are agitating for more change and are more critical of the role of the government and question more the democratic nature of the government.

According to Bothlale, a professor of political science at UB, BDP's longevity in power is reflected by really high numbers of popular vote, but their share has been declining, just above 50percent around 52percent. To him, Seretse Khama was royalty, thus giving him legitimacy. On the other hand, BPP was anti-colonial, anti-chiefs, something Botswana citizens did not relate to. A lot of things can explain BDP's success, e.g. there are a lot of advantages to incumbents. Bothlale argues that incumbency

\footnotetext{
${ }^{22}$ http://www.tradingeconomics.com/botswana/rural-population-percent-of-total-population-wb-data.html
} 
also gives the ruling party an advantage in the form of a head start. "There is a lack of a viable opposition" he adds, "The opposition has been fractured. They split their votes but we have a weak fractured opposition". They are forming a coalition and it is on the brink of collapse. First thing first, unseat the BDP first but they are now fighting for constituencies.

Tsie argues that there are three factors that contribute to the longevity of the BDP. First, the founder of the BDP was highly respected. There is no other politician who is as popular as he was; he was the embodiment of the nation and the legacy he left behind; they remember him with nostalgia, and if they were to vote otherwise it would feel like a betrayal to him. His leadership was exemplary in many ways. He was committed republican, by birth a paramount chief. The second explanation is the kind of coalition he brought together. He was able to bring the white population within the fold. Khama travelled extensively, had white cabinet ministers, and was able to bring chiefs on his side. Furthermore, he allowed a business community mainly of Asian origin to thrive, unlike in Indo-phobic Uganda under Idi Amin. The opposition has not been able to penetrate this coalition decisively except maybe in urban areas like Jwaneng, Gaborone, but the alliance of interest has remained intact. Thirdly the development performance of the BDP, they have delivered. Early days there was only $12 \mathrm{~km}$ of tarred rode. Now there is a whole road network, social services clinics schools, water is now widely available. Fourth, there is a weak opposition which is disjointed and vulnerable to defeat. Our society is now going through a transformation. This is the first generation which has faint recollection of Seretse Khama, and you see this shift in voting pattern. We foresee more 
difficulty. I don't ever see BDP ever winning Gaborone Central. They are likely to lose all five constituencies in this city.

Gobotswang asserts that Botswana's authoritative legitimacy is historical because BDP was formed and led by a royal person who was very charismatic and quite liberal. He used chieftainship and public service rallied behind the BDP. It is partly because of political consciousness. Botswana didn't go through the problems of its surrounding neighbors, former settler colonies which experienced racial segregation and separate development. As a result political consciousness was limited because the stimuli that facilitated political participation were greatly. However, Botswana citizens understood and appreciated chieftaincy. They accepted that a chief had to lead and this gave the chiefly institution legitimacy. The BNF managed to grasp one of the chiefs and until today that area of Ngwaketse is predominantly a BNF base, yet another indication of loyalty along chiefly lines. Over the years BNF eroded the popularity of the BDP. After the 1994 elections observers were convinced that BNF would take power in 1999. However, these hopes were dashed sue to the spilt of the BNF to form BCP. BNF grew but it lagged behind organizationally and management-wise. Resultantly, after 1999, Gobotswang argues that BDP has been ruling by default.

For others like Taolo however, the interpretation of Tswana leadership legitimacy is misinterpreted. He alleges that Khama's royalty before becoming president was no greater than any other chief. Instead, legitimacy of chieftaincy was used as a platform to garner support. The reason for Taolo's skepticism stems from the fact that once in power, Khama took away all the power of chiefs in Botswana in favor of executive power. This 
was done through the removal of land custodianship from chiefs, which greatly

diminished the significance of the institution. Furthermore, modern judicial systems were introduced to the subordination of traditional ones. This, Taolo asserts was done with the support of the colonial masters and a section of white South Africa (not the apartheid regime, which at the time did not condone his marriage to a white woman). As a result, Taolo contends that the consolidation of Khama's power directly marginalized other forms of authority, which he had based in candidacy upon. This research however disagrees with Taolo in that it believes Khama compromised on his role as chief to provide a more egalitarian role for the native Tswana population that would be equal and accessible for all. Him subordinating his chieftancy position to that of republican president, essentially removed the tribal/ethnic polarization that could have resulted under the new republic and paved way for the succession of new presidents like his successors Masire and Mogae, without the traditional rules of succession. The later election of his own son Ian Khama as the fourth president reflects both the enduring esteem of the chieftancy and the willingness to adopt new sources of legitimacy among Botswana citizens.

According to Taolo, the success of the BDP does not lie in its historical legitimacy, but in the failure and weakness of a strong opposition. Due to Botswana's diamond wealth and a process of transference the BDP has had considerable resources at its disposal that made it possible to run elections. The opposition has been cash strapped and their campaigns have concentrated in urban areas and that is where the opposition has recorded some success, with a few exceptions like Okavango. He alleges that bottom 
line; the victory division is a matter of resources. Via a process of stealth, the BDP was able to get the resources from the diamond wealth. The fact that the economy was doing well, meant that the BDP could get election harvesting schemes that will only be operational in the months before an election and would thereafter eventually die down. There is also a perception that the opposition is weak. It was weak because it did not have resources at its disposal. Taolo cites BPP as one such party that was decimated due to the lack of resources.

Taolo complains that the alternative view is stifled in that it does not find itself to the people who should listen to it. State-run television and domination of BDP on the air, in print and on the radio that deprives the people in the rural areas the information that would help them want to change government. People only hear one side of the story and have no access to an alternative view. The conditions of economic deprivation and poverty and unemployment are relatively high given the state of economic growth over the years. We have talked about unprecedented growth in economic growth in Botswana but we cannot talk about poverty eradication at a rate that matches this statistic. There has been a reduction in the level of poverty but not at the same speed as the acceleration. Having people living below poverty line and not having sufficient information, which is a recipe for safeguarding the establishment. The press moves about giving people blankets the people appreciate these blankets more from him because they cannot afford it. And the video cameras capture him giving these blankets creating an image of a very generous president. These handouts are a way to tell the poor people that one day you may also get a blanket. However, the statistics do not back Taolo's claim. Although not at the same 
speed, there has been a gradual improvement in most human development indicators in Botswana. Literacy rates have increased from 69.8percent in 1995 to 84.5 percent in 2010 according to the CIA World Factbook.

This section illuminates the views of respondents to interviews carried out in Botswana on the question of legitimacy. There seems to be an overwhelming view that the majority of the population voluntarily endorses the Botswana Democratic Party as legitimacy and this endorsement is repeatedly observed through the ballot box. It is also clear that they tie the agency of BDP to the country's economic success, thus providing it with legitimacy. The following section analyzes Botswana in comparative perspective to other resource-rich African countries.

\section{LEGITIMACY AND CONTINUITY IN COMPARATIVE PERSPECTIVE}

The resource curse has imposed upon its victims a crisis of legitimacy, where states' political landscapes are continually dominated by coercive ways to secure and maintain power. This is mainly through rentierism, which has led to either authoritarianism or violent conflict in resource-rich countries. In sub-Saharan Africa, this is all the more evident, as bases for securing the loyalty of citizens has been a challenge. The Botswana case illuminates a history where the contestation of legitimacy on the basis of ethnicity or governmental performance is greatly limited. This section provides an analysis of institutional continuity and legitimacy in comparative perspective to other African countries particularly two that suffer the resource curse: Nigeria and Angola. 
Sub-Saharan Africa has been plagued by a crisis of legitimacy. Lipset (1960:78), perceived the legitimacy crisis as a crisis of change from tradition to modernity. He argues that loss of legitimacy occurs when a political system no longer has the capacity to provide for new social groups. Many, including Ake 1981 (cited by Ogundiya (2009), argue that the crisis of legitimacy in Africa is a direct legacy of colonialism. Others like Osaghae (1994:21) maintain that the root of the legitimacy deficit in Africa "lies in the fact that legitimacy was not vigorously pursued as part of statehood under colonial rule." Furthermore, following Zartman (1995)'s [in Petithomme (2007)] assertion, African postcolonial states are successors to colonial territories, which were themselves exogenous creations. As a result, these independent African states inherently lacked legitimacy at the point of creation, thus reinforcing an early skepticism as to their empirical viabilities (Petithomme, 2007). In contemporary Nigeria, Ogundiya (2009) argues, the legitimacy of government is heavily dependent on the mode of power acquisition, ethnic identity, and solidarity as well as on the performance and leadership capabilities. Within this context therefore, Nigeria's crisis of legitimacy is a function of state incapacitation and policy failures. Nigeria provides a good comparison to Botswana because both experienced forms of indirect British colonial rule, which preserved traditional pre-colonial structures. It is also a country whose exports are highly dependent on one key non-renewable natural resource.

Unlike in Botswana, British colonial rule of Nigeria was a highly fragmentary process and the colony was decentralized into various spheres of influence. The colonial administration divided the territory into a Muslim north and a Christian south and 
installed a system of indirect rule. This system instituted by Frederick Lugard, Governor of Nigeria, would later exacerbate cultural differences within Nigeria that are still evident today. One result of British colonial rule in Nigeria was the remodeling of the colony into units of local self-government convenient to British colonial administration. Although traditional leaders continued to govern the native population, they were not independent like was the case of Botswana, but were agents of British colonial policy instead. In colonial Nigeria, caliphate titles could be retained by emirs but these were ultimately under the final authority of British district officers. The British High Commissioners, where necessary, could overthrow emirs and other officials. This situation did not occur in Botswana.

The arrangement put in place by Lugard at the unification of Nigeria, amalgamated the British government with the traditional administrative machinery. This created a hybrid system that linked British officials at the top of the executive, legislative and judiciary wings of government and native chiefs at lower rungs of authority. This had substantial structural and attitudinal repercussions for existing public and private organization as the colonial political domination of the society permeated government, trade, religion and the social life of Nigerian people. According to Kiggundu (1991), British colonial rule became an efficient tool for relegating and decimating the indigenous native institutions and management practices, as they were supplanted by western-style administrative structures that were invariably regarded as superior. The evolution of governance structure in Nigeria had to operate within the ambits of the firm conditions of colonialism favored by the British colonial administration (ibid). This was 
not the case in Botswana. In Botswana, indigenous governance structures were not coercively supplanted by colonial ones, they were voluntarily adopted as the fairest way to govern the population after independence (Duke, 2010).

During colonialism under the British, southern Nigeria adopted and relied on exogenous western traditions of rules of law, in which those that were governed were expected to support and obey. The coercive nature of British colonial rule can be observed in Nigeria's post-colonial era which is replete with instances where the military enforced its tentative, personalized authority utilizing aggressive approaches. Examples include the rules of General Ibrahim Babangida (1985-1993) and General Sani Abacha (1993-1998) whose methods of power acquisition and rule alienated the citizens of their country from their government. Furthermore, the harsh colonialism instituted by the British has fostered and exacerbated distrust and skepticism of government has since extended even to Nigeria's instances of civilian rule, even where democratic movements have been awash. This is in stark contrast to the Botswana case, whose internal and endogenous institutions were greatly left intact and sustained throughout its 80 years under British influence. In most cases in Botswana, the voluntary nature of power acquisition and succession along established laws facilitated the government's perceived legitimacy. Botswana did not have a military for nearly 15 years after independence, opting instead to focus on poverty alleviation instead of defense. It was only when crossborder incursions by Rhodesian and South African security forces in the mid-1970s threatened security in Botswana occurred that the government concluded that the country needed a military to protect its sovereignty. The Botswana Defense Force was thus 
established in 1977. Its mission has mainly focused on anti-poaching activities, disasterpreparedness, search and rescue response support to civil authorities and foreign peacekeeping.

Similarly, a crisis of legitimacy occurs in Angola, a dominant oil country and Botswana's diamond exporting counterpart in Southern Africa. Portuguese colonialism of Angola followed a principle of assimilation (assimilado). This was a direct form of rule that essentially disrupted indigenous Angolan institutions and altered them to fit the Portuguese model with the aim of all colonial subjects eventually achieving the full rights of Portuguese citizenship. However, the rhetoric of non-racialization was far removed from the reality of Portuguese colonial administration, which saw indigenous Africans viewed as inferior, making the achievement of assimilado elusive for most Africans. However, of importance to this dissertation is how Portuguese colonial administration affected institutional continuity and legitimacy in Angola. Essentially, by instituting a system of assimilation, Portuguese colonists essentially undermined traditional informal and formal institutions of native Angolans and replaced them completely with their own.

In the Weberian sense, contemporary Angola has been deemed a "failed state" due to the fact that the Angolan government only has limited control over the Angolan territory, thus failing to have monopoly of control as is required for a state to be legitimate. In Angola, unlike in Botswana, the government never enjoyed the legitimacy of the collective nation. The various factions were divided along ethnic and marginally ideological lines. According to Ostheimer (2000) [in Cillier and Dietrich (eds.) (2000)], there also exists a de-linkage of the Angolan political elite from Angolan society and an 
erosion of the state's service delivery performance including security, all which attribute to a loss of political legitimacy of the government.

\section{CONCLUSION}

The crux of the chapter's argument has been to show that Botswana has to a great extent been both a more "legitimate state" and with more "legitimate institutions" than its average African and resource-rich counterparts. This legitimacy is reflected in the way institutions are endorsed by a noteworthy portion of society. The chapter has gone to show the historical foundations of state and political legitimacy in Botswana. This is a history of an imperfect form of "protectorate" colonization, with limited engagement with the colonial administration and minimal destruction of existing institutions particularly chieftaincy. This facilitated succession and transition into power to be smoother than in other African countries. Furthermore, the institution of presidency was neatly superimposed onto the institution of chieftaincy through two of the country's four postindependence presidents, father and son, Seretse Khama ( $1^{\text {st }}$ president) and Ian Khama (fourth and current president) both of who were the rightful blood heirs to the majority BaNgwato tribe. This greatly cushioned the issue of transitioning types of legitimacy from traditional to legal-rational in the post-colonial period. Furthermore, the second and third presidents gained constitutional legitimacy which was never violently contested, but voluntarily accepted as the pragmatic way to move forward as an independent country. The election of Quett Masire (and subsequently his successor Festus Mogae) was the 
culmination of acceptance of legal-rational sources of legitimacy, as there exists competing bases of popular loyalty between traditional and elected authorities.

The respect for the rules governing the political order was reinforced during the first Khama presidency by the material outcome of economic change. Botswana citizens had seen the system work, without having disrupted the chieftancy, the historical symbol of continuity and change. This was facilitated by the BDP being willing to support the continued existence of the authority of chiefs, and the fact that the chieftancy did not challenge the hegemony of the national state. Early voter apathy in Botswana (31percent to 51 percent turnout averages between 1965 and 1980), could be viewed as a proviso to the initial limited legitimacy of the legal-rational framework. However, since no challenges led to outright violence, this could be viewed as an endorsement of the system, albeit with limited participation.

This chapter has also provided understanding of the way people's perceptions of what is right and their material interests interact; and also the way in which deeply embedded social and economic structures and "rules of the game" shape people's perceptions of their interests. This was reflected though insights from key informant interviews conducted around Gaborone's political and academic elite, of why the Botswana Democratic Party has continued its national stronghold. When a state is legitimate, it does not have to resort to coercion. Instead it relies on the constructive interaction between state and society limiting incentives for dissent. This study thus found legitimacy contributing greatly to Botswana's institutional quality. 


\section{CHAPTER FOUR}

\section{POLITICAL CULTURE AND INSTITUTIONAL QUALITY IN BOTSWANA}

\section{Introduction}

Explanations of Botswana's developmental success have looked into the role of prudent economic planning and good governance in facilitating Botswana's economic growth. As noted in Chapter 2, the modal reason cited for Botswana has been the existence of sound institutions. Acemoglu, Johnson and Robinson (2002) emphasize this by saying that good institutions particularly in the area of private property, the political leadership's choice of sound policies and the elite's motivation to reinforce strong institutions, have greatly shaped Botswana's fortunes. When compared to other countries in southern Africa and around the world, Botswana fares well on indices that reflect a country's sound institutions, including voice and accountability, political stability, government effectiveness, regulatory quality, rule of law and control of corruption (Iimi 2006:9.) In times of economic booms, the Botswana government has consistently been conservative in its spending, prudently saving surpluses in international reserves. In times of busts, the government has also for the most part, managed its reserves well to the point of never needing to resort to drastic structural adjustments or debt relief from international financial institutions (Sarraf, 2001).

Despite all this, Botswana does not have a monopoly over the craftsmanship and authorship of good policies in the abstract. Nearly every resource exporting country has well written developmental plans and policies, aimed at creating efficiency within their economies. However, in the case of Botswana, unlike most other resource exporters, 
these policies are followed through and successfully implemented. This begs the question as to why?

This dissertation maintains that explanations of the Botswana success story go deeper than the existence of certain institutions and policies. It argues that it is not the institution or the resource per se that determines the fate of a resource-rich country. Instead, it is the setting in which those institutions and resources are embedded that determines how the resource will be managed. This setting requires particular forces and interactions between the institutions and the resource that provides the most efficient equilibrium for effective governance. Additionally, these interactions and patterns of orientation to an effective political economy are heavily embedded in this setting. These modal orientations towards particular policy directions are reflective of a country or community's political culture.

Prior research on institutional quality that has employed "culture" as an explanatory variable for political outcomes assumes that political systems worldwide are heavily embedded in the distinct patterns of orientation to a narrow range of political actions. As Hall (1986) asserts, the behavior of officials and of citizens is greatly influenced by the political culture in which they exist in, operate in, and have been socialized by. This chapter examines the hypothesis that Botswana's unique peaceful political culture is what accounts for its institutional quality, making the country fare better than other resource exporting countries. 


\section{The Concept of Political Culture}

Political culture refers to the set of attitudes, beliefs and sentiments that offer meaning to political processes. In this sense, political culture also provides the fundamental assumptions and rules that govern behavior in the political system (Pye, 1968:218). Political culture embraces the political ideals and operating norms of a polity or community and is the manifestation in aggregate form of the psychological and subjective dimensions of politics (Geertz, 1973:93). Political culture is a product of a political system's collective history and life histories of members of the system. It is rooted in public events as well as private experience.

Two main traditions of understanding political culture exist. The anthropological tradition focuses on the symbolic dimension of politics and the effect of social group membership on political behavior. The psychological tradition prioritizes the role of individual psychological factors, including personality, political values and morality, and core beliefs inculcated through socialization during the course of cognitive development (Wilson, 2000). This dissertation argues that Botswana's political culture cannot be described within the limits of only one theoretical approach, and borrows influences from the various approaches at different points in time. It understands political culture in evolutionary terms, as a population phenomenon that evolves through a process of selection and retention of variation of beliefs and the behavior they give rise to (Campbell, 1965).

The Botswana case reflects the symbolic dimension of politics through the beliefs of myths and the practices of cultural rituals. This observation is inspired by the 
Weberian preoccupation with the significance of social action and the phenomenological focus on the socially constructed character of knowledge and society. Wilson (2000) defines culture as "the collective meanings that groups create, share, and symbolically express". As a result, political culture can be construed through engagement in local networks that revel in myths, symbols and rituals conveying the meaning and intensity of the norms that underwrite social solidarity. Why people select certain beliefs and are swayed by particular rituals is normally contingent upon social action and discourse.

According to Inoguchi $(2006)^{23}$ political culture is "the set of memories and identities, norms and values, beliefs and preferences, and practices and habits present in a certain community of people”. Thus defined, political culture is a patterned attitude towards political thought. Within this context, and following Lasswell (1990), Inoguchi (2006:9) defines politics as the authoritative allocation of values, expressing who gets what, when and how. It is this culture of politics that determines institutional quality. Similarly, for Verna (1965 p513) "the political culture of a society consists of the system of empirical beliefs, expressive symbols and values which defined the situation in which political action takes place". This research adopts Pye's (1965:7) assumption that "in any particular community there is a limited and distinct political culture which gives meaning, predictability and form to the political process." Similarly Carr (2007) maintains that political culture refers to "values that regulate governmental activities and direct a shared and public understanding of the proper operation of the public realm" (p.51). This definition reflects that political culture can determine how policies are

\footnotetext{
${ }^{23} \mathrm{http}: / /$ cco.cambridge.org/extract?id=cco19780521880473_CCOL9780521880473A010
} 
received, evaluated and implemented. As a result, political culture is public shared meanings and is thus socially constructed (Spiro, 1984).

Wilson (2000) argues that political culture can be viewed within a "psychological tradition" which emphasizes the role of individual psychological factors, including personality, political values and morality, and core beliefs inculcated through socialization during the course of cognitive development. The distinctive ways members of a group understand authority relations, are committed to specific religious and ideological opinions, fear social disorder and are markedly dependent, all reveal their political culture. Communities are characterized by modal and enduring personalities i.e. psychological constraints imparted from one generation to the next through the course of political socialization. This dissertation argues that Botswana's contemporary political culture has been the result of centuries of political socialization particularly within the context of Tswana customs and traditions. It assumes that individual views on authority and the state greatly reflect the aggregate culture of the society.

Max Weber's "protestant ethic" can serve as an example of how political culture contributes to institutional quality. Weber inferred reformation having altered the belief system of those who adhered to the Lutheran or Calvinist creed. Neither Luther nor Calvin intended to promote capitalism, yet their doctrines spontaneously strengthened individual responsibility, inner worldliness, and sobriety were thought to have set in motion a process of development, which resulted in the spirit of capitalism. These new values were all requirements of their new creed. Similarly, the seminal work by Putnam shows how similar formal institutions within one country, Italy, functioned differently 
and resulted in different outcomes in different regions of the country. The judicial system for example, which has been uniform for 150 years, operated differently in Northern and Southern Italy. This vast difference could only be accounted for by the beliefs and political culture of civil society which had emerged over centuries in the respective regions. This dissertation argues that similar to the protestant ethic and the northern regional political culture in Italy, political culture contributed to the creation of strong, responsive and effective representative institutions.

Political culture in Geertz (1973)'s view is a property of a collective and varying levels of analyses, nations, regions, classes, ethnic communities, formal organizations and political parties, can have distinctive political cultures. As a result there exist as a distinction between mass political cultures and elite political cultures. Elites in this context are what Putnam described as "those who in any society rank toward the top of the (presumably closely inter-correlated) dimensions of interest, involvement, and influence in politics". There is a general assumption within this research that a nation's political culture is largely integrated and that most people within the system have similar or compatible political culture orientations which are congenial to the political institutions (and/or to the ruling elites) within which they are subject to. This research focuses in on the political culture of Botswana citizens as a whole and makes few distinctions of political culture based on ethnicity, gender, rural/urban divide, age etc. Instead, the research aims to establish the political culture of the citizens of Botswana as an entity. 
Rosenbaum (1975) identifies three components of political culture: orientation towards governmental structures; orientation towards other political systems and orientation of one towards his or her own political activity. Utilizing data from Afrobarometer, this research attempted to evaluate these different components of political culture.

The first component reflects how an individual evaluates and responds to the basic governmental institutions in his society its symbols, official and norms collectively, the "regime". An evaluation by a citizen of governmental inputs and outputs i.e., how individuals feel and respond toward various demands for public policy (inputs) and policy decisions made by government (outputs) is at the heart of a citizen's participation in politics. These inputs and outputs include inventory of a person's knowledge concerning how state processes operate, what demands he may make upon government and how effective he believes government policy to be. The second component of political culture is the orientation towards other political systems. Political identification, political trust and the rules of the game are the different conceptions of an individual's subjective preferences. Political identification includes the political units (nation, state, town, and region), geographic areas, and groups to which one feels he belongs, that are in some significant subjective sense a part of his own social identity. This identification encompasses those units and groups to which he feels a strong loyalty, obligation or duty. Political trust in Rosenbaum (1975)'s view refers to the extent to which one feels an open, cooperative or tolerant attitude in working with others in civic life. Essentially, political trust expresses the intensity of a person's conviction that other individuals or 
groups mean him well or ill in political life. The "Rules of the Games" are an individual's conception of what rules should be followed in civic life. In Rosenbaum's view, these subjective preferences do not necessary need to be consistent with prevailing law and other norms supposed to govern civic conduct and are completely at the individual's discretion. The third component of political culture identified by Rosenbaum (1975) is the orientation of one towards his or her own political activity. The first aspect of this is political competence i.e., how often and in what manner a person participates in civic life, the frequency with which he uses the political resources available to him aim civic affairs. It may also include some evaluation of his knowledge of his political resources. A second aspect is political efficacy. This is the feeling that individual political action does have, or can have an impact on the political process. Political efficacy includes a belief that political change is possible and that one can accomplish change through civic action. In measuring political efficacy, individuals are customarily ranked on a scale according to whether their sense of political efficacy is high or low (Rosenbaum, 1975). This dissertation adopts the criteria delineated by Rosenbaum (1975) of determining aspects of political culture.

Political culture is of course the result of historical development and experience. Some factors that contribute to the formation of a particular political culture include historical experiences, collective values, founding principles, religious traditions, geographic location, strategic environment, economic capacity, educational levels, demographics, and existence central figures in the community (Kim, 2009:15-26). Inglehart and Welzel (2005) show definitively that political culture defined as values is 
systematically impacted by economic development over time. One critique of politicocultural approaches, however, is that they suggest that the personal choice and free will of individuals is limited by the cultural and social settings in which they are immersed. The implication that political decisions and behavior are predetermined by culture is a key weakness of this theory (Ramsay, 2008).

Moreover, as Inglehart (1990) argued, there is evidence of significant changes in political values within societies across the generations. Hence, it goes without saying that political culture is very dynamic and should never be treated as a static phenomenon (Hannerz, 1969). Culture evolves over time in response to changes in people's lives. Furthermore, as political culture often occurs within cultural clusters, diffusion between identity groups allows for the synthesis and/or the erosion of cultures over long periods of time.

While acknowledging the dynamic character of political culture, this dissertation focusses on the dominant political cultures that were exhibited in Botswana at critical points in its economic and political history. The quality of Botswana culture, at times under review, sheds light on the high levels of institutional quality observed in the country in the past 45 years. It makes no assumption; however, that Botswana culture is not changing or will not change over time. 


\section{POLITICAL CULTURE IN BOTSWANA}

\section{The Traditional Foundations of Political Culture in Botswana}

As discussed in the previous chapter, the British ruled Bechuanaland through means similar to the "indirect rule" prototype exercised in West Africa. Here, the subject was governed by his or her chief, sub-chief, or headman (the latter at the ward level). The colonial district commissioner worked in conjunction with the chief. According to Lewis (2006), the chief directed the kgotla, a traditional village gathering place with judicial, administrative and advisory roles. The kgotla endures as the central informal institution in Tswana governance and culture. Subsequent to consulting the kgotla, the chief arbitrated disputes and dispensed justice, allotted land for arable farming, grazing, home sites, and commercial ventures and distributed stray cattle at his pleasure. Chiefly decisions were also made on educational policy and public works projects. He scheduled the best times for agricultural activity and managed the general lives of his followers.

In the kgotla, the men discussed matters of economic and or political importance to the community. As described in the previous chapter, the morafe was divided into segments known as wards, which were representative of major ethnic and family divisions. Each ward arranged its houses around a central animal corral (kraal, lesaka) situated in front of the most senior kgotla, that of the kgosi. The kgotla, symbolized by a semicircular fence of stout, upright logs, sometimes topped by skulls of cattle or rhino (in the case of Shoshong) was located next to the central animal kraal.

Denbow and Thebe (2006) assert that certain traditional beliefs surrounded the institution of the kgotla. A fire was always situated at the entrance of the council place in 
order to prevent dangerous or harmful actions from entering. These could range from natural disasters such as lightning strikes, or from people with personal jealousies or grudges (baloi), from entering and interfering the kgotla's s deliberations. The kgotla was the avenue through which the chiefs communicated directly to their subjects, representing a quasi-democratic institution that permitted free speech, albeit within its limits, while at the same time allowing the kgosi to examine public reception of matters already discussed in private with counselors and advisors. There was an underlying expectation by the people that the chief be a modest, compassionate, and diligent man, while showing reverence for tribal customs and practices in his daily life. The Tswana proverb "kgosi ke kgosi ka batho" (the chief is a chief by the grace of the people) reflects this notion clearly, and demonstrates that even in pre-colonial Botswana, the people exercised buffering power over the chief. Chiefs commonly consulted with the community prior to decision making on matters of significance. While they did not necessarily accord the consensus of opinion in the kgotla, the tradition of consultation and seeking consensus in itself was deeply embedded in Tswana culture and society. In fact, according to Lewis in Harrison and Berger (2006)), the kgosi would seldom venture an opinion in the kgotla until all who sought to opine had done so.

The main tenets of democracy are reflected in this practice. The etymology of the term democracy demos "common people" and kratos "rule, strength" meaning that at the rudimentary level, Tswana customs reflected democratic ideals and the extent to which power belonged to the people. This to a large degree reveals pre-colonial Botswana's political culture, and the foundations of modern democracy in Botswana. According to 
Denbow and Thebe (2006) the kgotla was open to all members of the community with the exception of recently arrived immigrants and some lower-status commoners. Order of seating was hierarchical and followed the order of status and seniority. One major exclusion was the political participation of women, however, who were deemed as "incompletely socialized beings" and referred to as Makope or "yellow locusts" (Denbow and Thebe, 2006: 22). This was to later be a problem during colonial periods as women often headed households where migrant mine workers were based in South Africa and these households would go for prolonged periods of time without representation within the kgotla. Proverbs such as "ga di nke di etelelwa je manamagadi pele" (households and nations cannot be headed by women) greatly reinforced the disenfranchisement of women within pre-colonial Tswana society. Nonetheless, in exceptional circumstances, Tswana populations have been led by regent queens. This was the case of Queen Ntebogang Gaseitsiwe, who stood in as acting chief for Kgosi Bathoen II of the Ngwaketse between 1924 and 1928.

Although Molutsi (2004) contends that historically Tswana society was thoroughly authoritarian and strongly dominated by the male elders, Botswana's contemporary kgotla has been adapted to modern democratic systems and practices. This has been achieved first, by making sure that not only men can be chiefs, by appointing and inaugurating females to chiefly roles and second, by extending the system beyond its traditional rural ethnic base into urban areas. The institution is still biased towards elderly male representation, although in principle anybody, young and old, is eligible for chieftaincy. 
According to Denbow and Thebe (2006) what set the stage for Botswana's later success with democracy was that even in the pre-colonial times, considerable freedom was allowed for individuals to discuss and criticize community affairs within the kgotla, a salient element of Tswana cultural practice that existed for centuries. They cite Campbell's observation that:

"Such is the freedom of speech at those public meetings, that some of the captains [headmen] have said of the King, the he....is not fit to rule over them."

This observation was the basis of Maundeni (2004)'s argument on Botswana's political culture, even in contemporary times. Maundeni (2004) contends that the main reason cited to account for Botswana's weak civil society has been that historically it has staged very few violent clashes with the government with the intention of reversing governmental policy ${ }^{24}$, which is the hallmark of strong Western civil society. He argues that this Eurocentric yardstick for measuring civil societal strength is inappropriate for the study of Botswana's politics. Botswana is characterized by lengthy debates and civil confrontations and rarely resorts to violent confrontation. Instead Maundeni (2004) says Botswana citizens resort more to "mutual criticism". Following Durham (1999)'s emphasis on 'civility' - i.e., the local cultural emphasis on the moral nature of political action and the political aspects of a person's agency, Maundeni (2004) concedes that in Botswana, the criticism of chiefs has long been a central feature of public debate. He agrees with Schapera (1965)'s assertion that it has been entrenched in the gaudy imagery of courtly praise poetry since ancient times:

\footnotetext{
${ }^{24}$ Civil society activism need not be hostile to the state; it might just be suggestive of good ideas, or promoting of good legislation, etc.
} 
In general, we may say, the poems deal mainly with events in which the chief was personally involved, or failing all else, with what is expected of him ... The contents always include eulogies of the chief himself, though sometimes also ... direct or implied criticism of his conduct or disposition.'

Maundeni (2004) argues that what should be emphasized is that public criticism of chiefs occurred in their presence and in public meetings, and that all matters of public policy were settled at an assembly open to all men of the tribe, and variously dubbed pitso, lebatla, or phutego. These were smaller, localized varieties of the kgotla, with the former being held mainly at the tribal level. Such gatherings occur frequently, early in the morning in a tribal council-place near the chief's residence. Customarily only the men present in the capital would attend, the business discussed and decisions reached being communicated to the inhabitants of remote villages through their headmen. However, on special occasions the men from outside are also beckoned.

Maundeni (2004) argues that the prevailing Tswana political culture stresses open discussions to violent engagement. In fact, violent behavior is peripheral to Tswana culture and has never enjoyed moral support as demonstrated by the Tswana language's emphasis on "ntwak golok e a molomo" (conflicts are best solved through discussion). He laughingly recalls a 1989 incident when two Herero men began fighting in a ward kgotla (chief's court) in Mahalapye. This became the subject of general ridicule for days. When men in the Mahalapye kgotla became openly hostile to persons or to the general debate, they would be compelled to leave and their comments dismissed (Maundeni (2004). 
Instead, Tswana culture warrants that criticism be done within the confines of the kgotlas. In the early 1980's, an old man in the kgotla in Mochudi was broadcast over the radio when Vice President Sir Ketumile Masire became president at the death of Seretse Khama, requesting that President Masire come to a kgotla meeting. During the meeting, an old man accused him of being a mmina phiri (one who dances the hyena) meaning that he has a hyena as a totem and so by implication if from a junior morafe or origin and thus not a high enough social rank or caste to settle the dispute of an Ngwaketse king (Maundeni interview). Another example is the well-publicized incident when the Minister of Local Government and Lands suspended Kgosi Seepapitso IV of the Ngwaketse for "insubordination" done within the confines of the kgotla. A traditional right to freedom of expression was respected in all cases, a right reflected in two Tswana proverbs:

"Mmualebe o a be a bua la gagwe" ("Everyone has the right to say what he likes in the $\mathrm{kgotla}$ ) and

"Mafoko a kgosing a mantle otlhe" ("Words spoken in the kgotla are the most beautiful").

In all these cases, freedom of expression was respected and there was no punishment for criticizing the highest official. Another saying encapsulates this tolerance of opposing views: "Ntwa kgolo key a molomo" ("the highest form of war is dialogue"). The deep cultural embededness of such sayings helps explain why Botswana takes care to be one of the most democratic countries in sub Saharan Africa. According to Maundeni, when airing out a grievance in pre-colonial Botswana, the subjects usually resorted to 
public poetry at the kgotla. Everybody, including the chief was open to criticism, but instead of mouthing off e.g. through cursing or causing a scene in public, they utilized the kgotla forum.

Culturally the kgotla was not open to women and minorities. Nevertheless, the chief's mother was regarded as the steward of the chieftainship and ruled on behalf of an heir who was not yet of age. Participation also excluded some minority ethnic groups such as the BaKgalagadi, and BaSarwa and favored the dominant Tswana ethnic groups. These minority groups therefore historically have had no representative voice within the kgotla institutions. According to Bock and Johnson (2013) these small nomadic groups moved sporadically in response to the local migration of game. Their organization was focused on extended family relationships and little evidence of central authority existed. Other groups like the Wayeyi people lived in semi-permanent, patrilocal, extended family settlements with a hereditary headman as the political focal point. Inheritance following Wayeyi tradition was matrilineal, therefore giving women a level of esteem not usually experienced under Tswana practice. Beginning in the late 1700s, the chief of the BaTawana, a Tswana tribe, began incorporating communities of the Okavango Delta into his traditional political structures and exerting political influence over them. This greatly undermined the matrilineal orientation of property rights customs in these communities as they were gradually replaced by patrilineal Tswana customs. This was further exacerbated by colonial administrators whose political control integrated the traditional Tswana institutions into government based ones. Today headmen are primarily government employees, assisted in their duties by police, the courts, and civilian 
committees. The Tswana kgotla style of government has been adopted locally, however, with restricted political and social socialization to members of other ethnic groups.

Although through a system of assimilation to the dominant Tswana culture, the peaceful political culture did extend to other minority ethnic groups in Botswana particularly how they have always reverted to peaceful means when airing out grievances. In the following chapter, I will go into more detail on the intricacies of Botswana's ethnic relations but it is key to note that ethnic relations in Botswana have rarely ever escalated into war, even with the existence of disgruntled minorities. When asked why minorities groups have remained dormant for such a long time without resorting to violence, as evidenced by a history of peaceful coexistence among ethnic groups in Botswana political science graduate student Lawrence attributes this to history. He compared the Tswana kingdom to the warrior and crusader Zulu and Ndebele states, which were forever on the warpath. Botswana's pre-colonial history as well as colonial history was peaceful, but the history of warfare was not long drawn. He argues that the various identity groups opted to splinter away and break up before resorting to violence. The Tswana kingdom broke up when three brothers Ngwato, Ngwaketse and Tawana mutually agreed to form different tribes. However, he acknowledges that the Tswana kingdom was not as highly centralized as the Zulu and Ndebele states, and therefore never fully constituted a huge empire. This made it easier for groups to coexist.

Pre-colonial Botswana consisted of small states that coexisted relatively peaceful with each other, rarely resorting to violence when disputes emerged. This was unlike the neighboring Zulu and Ndebele states whose militaristic political culture was very 
confrontational and polarizing. Botswana did not endure rapacious colonial rule and thus had a cordial relationship with its colonizers. As a result, the fundamental nature of Botswana's pre-colonial political culture was kept in place. Pre-colonial political culture can best be summarized as one that promoted dialogue and consultation over warfare when addressing grievances. This dialogue has been facilitated by the perpetuation and centrality of the kgotla institution. Traditional Tswana political culture was thus more compatible with the ideals of democracy that would be the foundation of the state left by the colonists. Tswana political culture reflected most of the key principles of democracy. It emphasized citizen participation through opening up the kgotla to royalty and subjects alike. The kgotla institution also kept chiefs and traditional leaders in check, providing for accountability and transparency of the system. Disputes were resolved amiably and subjects of the kgotla accepted the results of the rulings. Traditional Tswana political culture also esteemed mutual criticism, leading to compromise a key tenet of democracy. 


\section{Botswana's Elite Political Culture}

At independence Botswana had two sets of elites: the chiefs, who represented traditional world views, and new elite, who reflects Christian liberal values and a leaning towards democracy (Sebudubudu and Molutsi, 2009). The traditional elite were primarily of Tswana stock, thus possessing a common socio-cultural background. Botswana's new elite was highly educated, with most members having studied aboard thus developing a common political and social value system. The differences of the two groups of elites were reconciled on three separate occasions. First, the coalitions formed at Constitutional Talks of 1963 in Lobatse town; second, the formation of political parties with chiefs having a secondary role; and third the establishment of local democratic government institutions, immediately following independence, reducing the influence of the chiefs while incorporating them into the new system.

The Lobatse talks were a key moment defining Botswana's elite political culture. They defined the type of state that would exist post-colonial and whether or not the Chiefs would be the key inheritors of the new national state. Although present at the talks were the radical ANC-inspired Bechuanaland People's Party, white settlers who wanted to keep land and chiefs who wanted to inherit the new state according to traditional law, the result was the emergence of a coalition of new and old elite, of multi-ethnic and multi-racial background, and of moderate political character.

The second thing that defined elite political culture was the formation of a grand coalition of political parties. The three key political parties that have dominated Botswana politics for the past 45 years are the Botswana People's Party (BPP), The 
Botswana Democratic Party (BDP) and the Botswana National Front (BNF). Although inspired by varying and at times polar political ideologies, the main political parties of Botswana handled political challenges and disagreements through various means. At various points in Botswana's history, consultative commissions hand conferences have been held to negotiate matters of importance to all political parties. One example is the consultative commission under President Festus Mogae which saw the negotiation of the perceived discrimination and under-representation of minority tribes in the House of Chiefs. Although not completely resolved, the commission set up a platform to do so. The commission also used the kgotla, to debate matters of national interest. Similarly, in the late 1990's an All Party Consultative Conference was held to discuss issues relating to electoral reform, the voting age and postal voting from outside the country among the political parties.

The third key aspect of Botswana's elite political culture has been the incorporation of traditional leadership into modern local government institutions. The institutions of chieftaincy and of the kgotla (traditional assembly place and court) which were political, judicial and social pillars of the traditional Tswana society still exist as integral aspects of the contemporary Botswana. The House of Chiefs (Ntlo ya Dikgosi), for example, has an advisory role in parliament, and thus are a crucial aspect of the country's legislature. They are also an essential part of the judicial and administrative systems at district and national levels (Sebudubudu and Molutsi, 2009).

These three aspects greatly characterize the elite of Botswana as having kept the main principles of dialogue and consultation that characterized traditional Tswana 
political culture while adopting new forms of governance through political parties.

Legitimate forums like the kgotla are also utilized by the elite to manage disputes that exist among themselves as well as the population at large. This to a great extent increases institutional quality in Botswana as it neutralizes threats.

The Tswana political culture is very conservative, according to Professor of Political Science at the University of Botswana, Osei-Hwedie. When asked to characterize Botswana's political culture, she was quick to state that Botswana elites do not condone radicalism. Their political culture is characterized by a refusal to adopt radical and extreme views and tends to be middle of the road ideologically. The country's elite have not resorted to the levels of corruption characteristic of most states with natural resource exports. Osei-Hwedie cites Botswana's championing of liberal property rights regimes and deliberately forgoing socialism or the one-party state unlike Zambia and Tanzania. Botswana remained largely free-market in its economic orientation and its pragmatic elite who were not excited about splashing money on luxuries, like their other African counterparts. They deliberately assessed what was needed in the country and decided to have more reserves than spending the money.

Osei-Hwedie argues that there was a material aspect to the Tswana political culture. Here the elite a great number of Botswana's elite both old and new belonged to a class of were cattle owners who revered cattle more than money. They have more faith in cattle investments than putting money in the bank. This provided a structural class based on wealth that required work, cultivation and cattle, unlike diamond wealth, which is highly lootable (Lujala, 2005). This is unlike the practice in countries like Nigeria, 
whose elite have contracts and tenders primarily within the oil sector of the economy. Osei-Hwedie compared Botswana to Zambia. The Zambians were not cattle owners and most got money put in overseas bank accounts. The Tswana on the other hand, tended to invest on cattle, which in turn backed up the burgeoning beef industry. So as a result, the Tswana elite invest more in the primary sector of the economy, the beef industry, and not the diamond industry. They have pragmatically left that industry to the management of Debswana and other private institutions to efficiently manage the resource.

The elite political culture in contemporary Botswana borrows a number of insights from both pre-colonial tradition and the liberal world viewpoint. Botswana's political elite comprises of a grand coalition of traditional elite and modern elite, local people and foreigners, cattle owners and former migrant workers, conservatives and radicals, all who were willing to compromise for the greater good of the country. According to Leonard Sesa, lecturer of political science at the University of Botswana, this has facilitated in the lowering of unpredictability and instability in the country.

\section{Political Culture in Botswana: Traditional vs. Secular}

The Botswana case is interesting in that it does not neatly follow Inglehart and Welzel (2005)'s designation of creating a democracy due to the adoption of secularrational values. Secular-rational values are those based solely on logic, reason or moral intuition, and not derivative of the ostensible supernatural revelations or guidance generally associated with religious ethics and values. According to Inglehart and Welzel (2005), societies that highly value secular-rational and self-expression values, tend to be 
more democratic that those that reflect traditional and survival values. They also link these cultural values to the levels of socio-economic development, arguing that modernization or the changes brought about by socioeconomic development, brought with them societal, cultural, and political changes resulting in rich countries highly valuing secular-rational and self-expression values while low-income nations tended to cluster on the opposite end of the spectrum.

This assertion goes counter to the observation of Botswana which generally reflects that, Botswana's democracy has historical pre-colonial roots and is not a result of modernization and industrialization, which came after independence as Inglehart's neomodernization theory would argue. Botswana's foundation of democracy predates the introduction of machinery for economic growth.

According to Tsie, there are regional variations in the adoption of traditional and secular value systems in Botswana. For example, the central district, where Khama comes from, traditional values are very strong and salient features. In Kgatleng, which borders South Africa however, secular values are becoming more prominent. In Palape and Shoshong and Mahalape the opposition has won recent elections. Basically, constituencies which tend to vote for the opposition are deemed to be more secular than constituencies which vote for the Botswana Democratic Party (BDP). Constituents in Tlokweng and Kgatleng regions, which Tsie deems to lean towards secularism, tend to flip-flop on party allegiance. The paramount chief left his chieftaincy to pursue a political career in 1960. As Tsie puts it "voting by instinct is fast fading away in Tlokweng". Tsie 
argues however that as education levels rise, people are tending to embrace more secularrational values.

\section{Mass Political Culture in Botswana}

Systematic study of mass political culture has always been challenging particularly in sub-Saharan Africa due to its heterogeneity and diversity. This section will however attempt to evaluate how mass political culture in Botswana provides explanation to its high level of institutional quality and its resultant escape from the resource curse. The first part of the analysis will look at how key informants characterized Botswana's national character and mass political culture, and how these can be used to explain Botswana's institutional quality. Second, the section will utilize Afrobarometer data to find empirical evidence of Botswana's mass political culture. Both sets of data reflect a society with a high positive orientation towards the state reflecting the ideals of democratic political culture.

\section{Botswana's Mass Political Culture described}

The majority of Botswana citizens are happy with the way things are done in their country and the way the economy was being managed by the government. When asked how Botswana citizens evaluated their state, respondents such as Lawrence, a private citizen and former student at University of Botswana, stated that generally the citizens are content with the state. He attributes the interaction between government and the people, facilitated by the kgotla forum where government and citizens engage, as the reason 
behind this public endorsement of the state. As a result, according to Leonard Sesa, lecturer of political science at the University of Botswana, Botswana's mass political culture is very predictable, alleging "You can write the election report months before the elections even come.”

Due to Botswana's economic performance, the country's political culture is characterized by apathy and passiveness. The voter turnouts at the 1999, 2004 and 2009 elections were only 41.98 percent, 44.00 and 62.20percent of eligible voters respectively (International Institute for Democracy and Electoral Assistance, 2013) ${ }^{25}$. This has been characteristic of the country since independence and only recently has there been sustained criticism of government reflecting more political engagement. Gladys Mokhawa argues that the issues that preoccupy Botswana citizens politically are usually very superficial and alleges that Botswana citizens are misusing the forums due to lack of issue priority.

"Botswana citizens do not tend to make grievances about the budget or the economy, but when the alcohol tax was increased there was great disgruntlement particularly among the urbanites" - Dr Gladys Mokhawa.

According to Pitso and Obot (2009) controversy erupted in 2008 over the proposal by President Khama to impose a 70percent levy on alcohol products. The industry responded by threatening to go to court and as a result the levy was reduced to 30percent. When citing issues of importance to Botswana citizens, the issue of the alcohol tax kept on coming up in interviews conducted, reflecting the possibility that

${ }^{25}$ http://www.idea.int/vt/countryview.cfm?id=34 
Botswana citizens are so jaded that their only worries are alcohol taxes. Generally, issues of high politics or high relevance to the process of democratization are argued among Botswana citizens, argues Mokhawa, and neither are socio-economic issues such as the diamond sector or education. Botswana citizens, she contends, are generally insular people, inward looking into Botswana, but they fail to be cognizant of the fact that there is a lot of competition within the region in terms of trade, investment and aid. This she says further consolidated the passivity of Botswana citizens.

According to Lawrence, a growing segment of the population is becoming disillusioned. This segment mainly comprises of the urbanites whose needs go beyond social services like road networks and hospitals. These are people who are saying as much as they have had development, they believe that any government should do these as basic role. They expect an extension of provision of social services from the state. Material-wise, the consensus is that the state is capable, with the exception of the global economic or localized upsets. One recent upset has been the 2011 government strike over salaries, one of a few in the country's history. Close to a 100,000 public servants, including about 1,500 considered essential workers, stayed away from their posts while government and unions disputed over salaries. This according to Mokhawa could be the heralding of a new, more active and participant mass political culture in Botswana.

\section{Afrobarometer Reflections of Mass Political Culture in Botswana}

When investigating the political culture of any society, it is important to concentrate upon common political culture orientations, as these are assumed to be most likely to influence the political process, as they affect the behavior of large masses. In 
order to get a glimpse of broader political culture in Botswana, this research thus utilized data obtained from studies conducted by Afrobarometer to gather evidence that ascertains contemporary Botswana's public perceptions towards its political system. Afrobarometer is an independent research project that measures public attitudes on political, economic, and social matters in African countries. Afrobarometer results are based on face-to-face interviews of individuals and are considered reliable and generalizable. National representative samples are selected across all participating countries, with major variations (i.e. ethnic linguistic differences, captured by stratifying by region and province, as well as urban rural). Currently four rounds of Afrobarometer surveys have been undertaken in sub-Saharan Africa, with Botswana having participated in all four rounds. Countries that participated in Round 1 included Ghana, Mali, Nigeria, Uganda Tanzania, Botswana, Lesotho, Malawi, Namibia, South Africa, Zambia and Zimbabwe. The second round included all countries of Round 1 plus Cape Verde, Kenya, Mozambique and Senegal. Round 3 included Round 2 plus Madagascar and Benin. The project is coordinated by the Institute for Democracy in South Africa (Idasa), the Centre for Democratic Development (CDD-Ghana) and Michigan State University. The latter largely acts as a technical partner.

Afrobarometer utilizes a standardized instrument to obtain its data. The same questionnaire questions are administered, adjusted only for local countries' conditions. The field work is conducted by the natural partners' research teams with Afrobarometer supervising to ensure that the same questions are asked so as to be able to make reasonable cross-country comparisons. 
Afrobarometer data on public perceptions helps map out the political philosophy and culture of Botswana i.e., ideas on the ideal organization and existence of governmental, political and economic life. This dissertation used Afrobarometer to obtain public opinion measures to gauge political culture from a variety of viewpoints, by surveying people on their views of the general authority and legitimacy of the democratic

political system. Furthermore it measures popular outlooks on democracy and measures the degree of confidence and trust citizens place on the political system. The data was used to appraise the understanding of democracy, the support for democracy and the denunciation of alternatives in Botswana, the views on democratic institutions in Botswana as well as the level of trust and confidence in the government.

\section{The Meaning of Democracy in Botswana}

When asked "what if anything does democracy mean to you?" the modal response reflected a desire for civil liberties and personal freedoms (27 percent of respondents in 1999 and 32 percent in 2005). The table below shows the distribution of all substantive responses offered. 
Figure 4.1: The Meaning of Democracy in Botswana

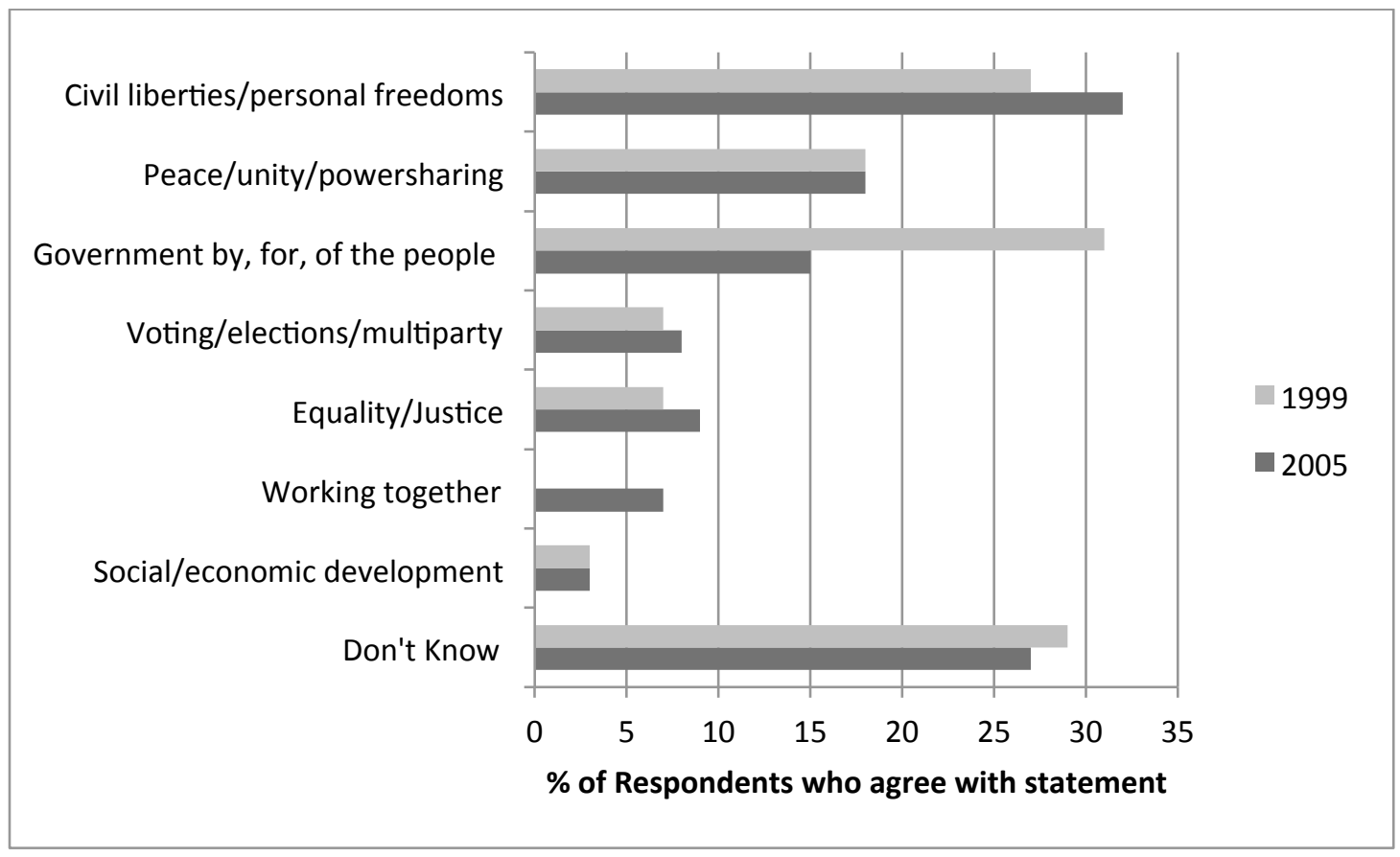

As is shown in Figure 4.1 above, Botswana citizens have no consensus over the meaning of democracy. However, over a third of respondents revere aspects of democracy such as civil liberties and personal freedoms. This reflects that democracy within Botswana society is conceptualized within the liberal paradigm in terms of civil and political rights. This is an interesting finding as it reflects a reshaping of cultural norms from its roots in Botswana, which historically were compatible with democratic ideals. The introduction of Christianity into Botswana's society mainly affected this reconfiguration. Botswana type democracy in common with Christian conservatism emphasizes traditional moral values such as on marriage and abortion. It also holds a view of the evolutionary development of society, as opposed to a revolutionary stance and emphasizes on law and order. It also advocates for the rejection of communism and emphasizes a support for market economy. This would greatly reflect the right-wing 
politics of the Botswana Democratic Party which has gained popularity and legitimacy since independence.

According to Rose et al (1998) democracy exists within two main paradigms: the intrinsic, where people view democracy as political and civic rights, and instrumental, where they view in terms of democracy's substantive economic and developmental outcomes. The Botswana case reflects equilibrium between the historical roots of democracy and the adoption the liberal paradigm as well as equilibrium between the intrinsic and the instrumental paradigms of democracy. This has enabled a smooth transition from pre- to post-colonial institutions, while keeping the core values of both intact, and essentially strengthening institutional quality in the process.

\section{The Support for Democracy and Rejection of Alternatives in Botswana}

When Botswana citizens were asked: Which of these statements is closest to your opinion?

A. Democracy is preferable to any other kind of government.

B. In some circumstances, a non-democratic government can be preferable.

C. For someone like me, it doesn't matter what kind of government we have.

As is depicted in the Figure 4.2 below, an overwhelming majority selected democracy as preferable to other forms of government (85percent in 1999, 66percent in 2003, 69percent in 2005 and 85percent in 2008). Respondents were further asked whether they approved or disapproved with the following scenarios: 
Question: There are many ways to govern a country. Would you disapprove or approve of the following alternatives: The army comes in to govern the country?

Question: There are many ways to govern a country. Would you disapprove or approve of the following alternatives: Only one political party is allowed to stand for election and hold office?

Question: There are many ways to govern a country. Would you disapprove or approve of the following alternatives: Elections and Parliament/National Assembly are abolished so that the President/Prime Minister can decide everything?

As is reflected in the Figure 4.2 below, Botswana citizens overwhelmingly reject military rule ( $85 \%$ in $1999,79 \%$ in $2003,80 \%$ in 2005 and $89 \%$ in 2008 ); reject oneparty rule ( $78 \%$ in $1999,68 \%$ in $2003,82 \%$ in 2005 and $80 \%$ in 2008$)$ and reject oneman rule ( $88 \%$ in $1999,85 \%$ in $2003,89 \%$ in 2005 and $93 \%$ in 2008.$)$ 
Figure 4.2: The Support of Democracy in Botswana

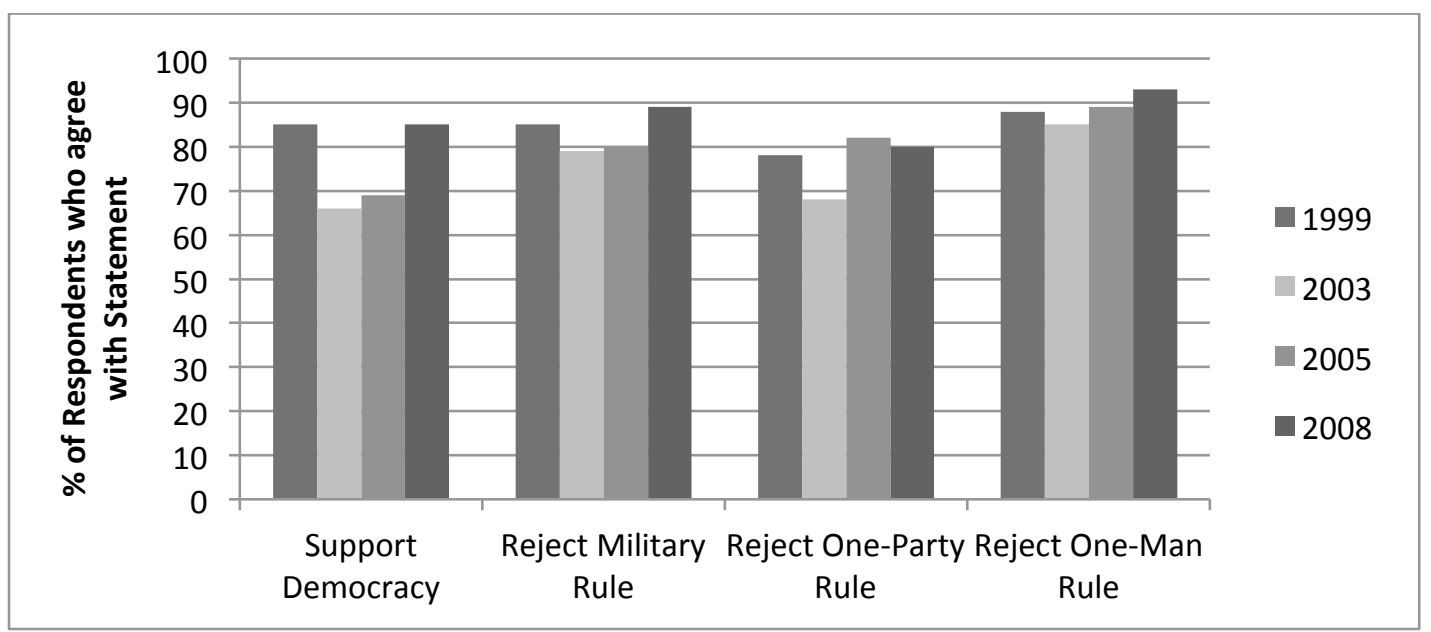

As is reflected in Figure 4.2 the vast majority of Botswana citizens feel that there is no place for an unelected leader within political office, even under difficult circumstances. Democracy remains the overwhelming popular choice. Over the years, of Afrobarometer surveys, Botswana citizens have consistently rejected military rule, oneparty rule as well as one man-rule. These responses reflect that democratic institutions are firmly entrenched within Botswana's political culture.

\section{Views on Democratic Institutions in Botswana}

When asked: Which of the following statements is closest to your view? Statement A or Statement B:

A: We should choose our leaders in this country through regular, open and honest elections. 
B: Since elections sometimes produce bad results, we should adopt other methods for choosing this country's leaders.

Figure 4.3 Views of Democratic Institutions in Botswana

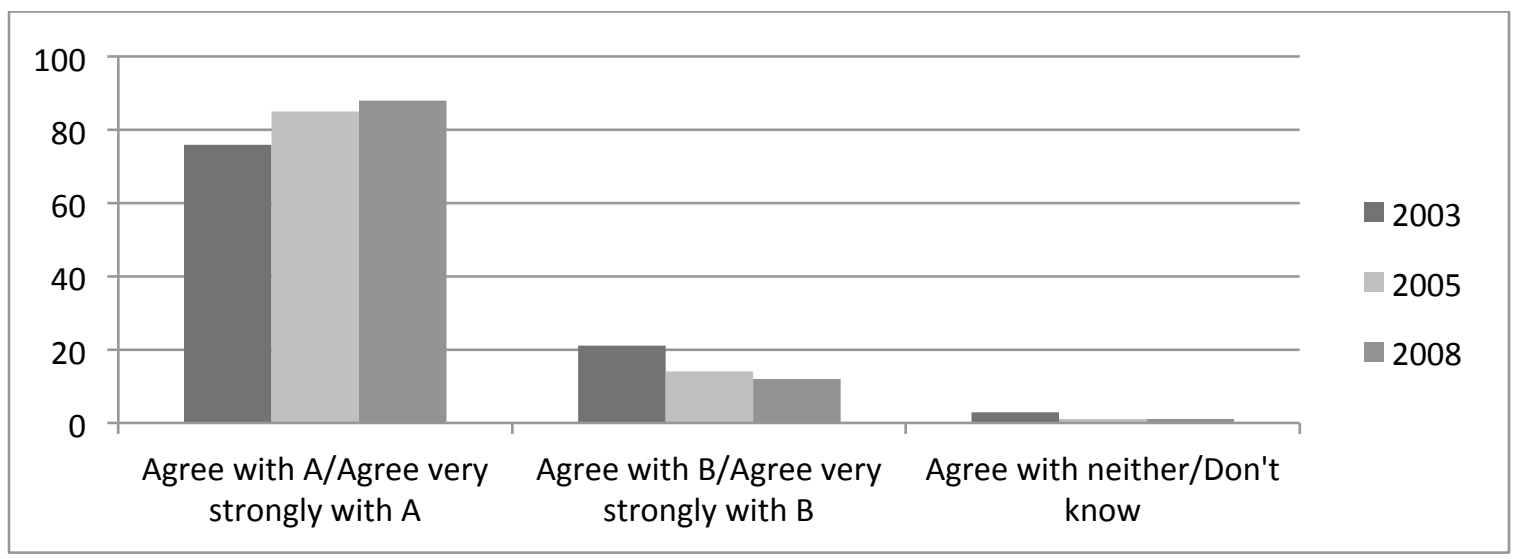

As shown in the Figure 4.3 above, over time, more Botswana citizens were agreeing with the need for regular, open and honest elections as the best way to select leaders with 76percent in 2003, 85percent in 2005 and 88percent of respondents in 2008 endorsing this form of leadership selection. This overwhelming result greatly reflects a democratic political culture which emphasizes free and fair competition when selecting representatives for holding official posts. 
Figure 4.4 Freedom of Political Participation

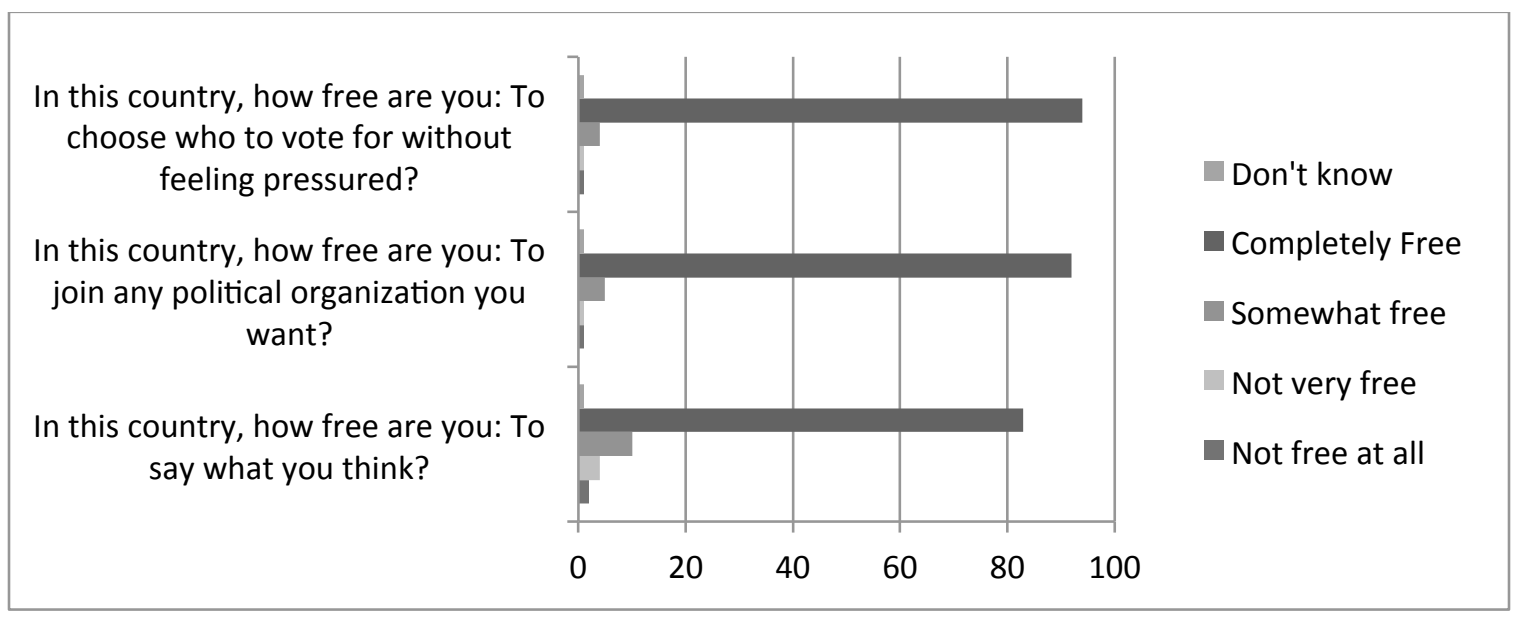

Figure 4.4 shows that Botswana citizens feel overwhelmingly free to participate in political activities and to air out their views without fear from the government or any other forces threatening them. This reflects an endorsement of democratic institutions within Botswana as the most popular definition of democracy cited earlier in the section was the reverence to civil and political liberties.

When citizens of a country greatly endorse the politics of their country, this enhances institutional quality and makes policy implementation more efficient. The endorsement and support given to the state by Botswana citizens through the evaluation of their politics as free and fair, enhances the democratic process and brings about disincentives for dissent and repressive behavior that undermines institutional quality. Afrobarometer data reflects that Botswana citizens greatly endorse liberal democratic values such as equal rights for women, free speech, and the rule of law. 72 percent agreed that "The President must always obey the laws and the courts, even if he thinks they are wrong"; only 23percent agreed that "Since the President was elected to lead the country, 
he should not be bound by laws or court decisions that he thinks are wrong" (Bennett, 2005). This reflects Botswana citizens' desire to check the powers of the president and to provide accountability to the residency institution. Seventy-three percent of Botswana respondents classified the country as "a full democracy" or "a democracy with minor problems" and only 3 percent of citizens did not view the country as a democracy ${ }^{26}$. This great endorsement of Botswana provides for its institutional quality.

The following section views Botswana's political culture in comparative perspectives.

\section{Botswana Political Culture in Comparative Perspective}

African exceptionalism has been used to analyze Africa's divergent trajectory when it comes to variables such as democratization and development, both politically and economically. Truly, Africa is distinctive, with a dissimilar history and matchless experiences to other continents and world regions. For instance, no other continent has been disrupted by the dynamics of slavery and colonialism to the extent Africa has. And as a result, its political culture has reflected some of these peculiarities. One key feature is the prevalence of one-party states or de facto one-party states on the continent.

Africanists have argued that the one-party model is most compatible with African culture and has long established a basis of rule across the continent (Nigeria Open University, 2009). Pre-colonial Africa was characterized by community consensus within politics as

\footnotetext{
${ }^{26}$ http://www.thuto.org/ubh/bw/society/afrob1.htm
} 
opposed to the competition basis of political parties and their opposition. Along similar lines Smith (2003) argues that one-party government in Africa was a reflection of autocratic form of government inherited from Africa's traditional past and colonial history. Traditional African society had its own forms of democratic decision- making. In Smith's words, "pluralism and multi-party democracy are not inherited from the past, multi-party democracy was too alien an importation for it to survive in the local political culture, traditions and history" (NOU, 2009: 143).

This is also evident when comparing Botswana with other non-renewable natural resource exporters in Africa. One useful point of comparison is Nigeria. Historic traditions have wrought an intricate modern political culture in Nigeria. This political culture is one characterized by ethnic conflict, corruption, and a politically active military, political practices that to a large extent are absent in Botswana. One persistent accolade conferred on Nigeria, according to Salisu (2002) is that it is one of, if not, the most corrupt country in the world. This branding of Nigeria is reflective of its recurrent succession of despotic regimes, disregard of human rights, political volatility and economic maladministration all which have contributed to cast Nigeria in opprobrium worldwide. These factors have also destabilized Nigeria's economic growth and development capacity, as well as compromising human development.

When compared to Botswana, it is clear that most aspects that account for Nigeria's volatile political culture are largely absent. Botswana is generally more 
"ethnically homogenous ${ }^{27, "}$ than Nigeria empirically. In addition, the influence of Islam, although growing, is very minimal at best. Furthermore, Botswana is unified by a common political culture, that of BaTswana (as will be discussed in Chapter 5) whereas Nigeria has a mosaic of many ethnic and religious cultures, with no unifying force.

Trust is an important component of political culture. Below is a comparison of the views of trust in Nigeria versus in Botswana of the institution of presidency. When asked "How much do you trust each of the following or haven't you heard enough about them to say: The President?"

Figure 4:5 Trust in the Institution of the Presidency: Nigeria vs. Botswana

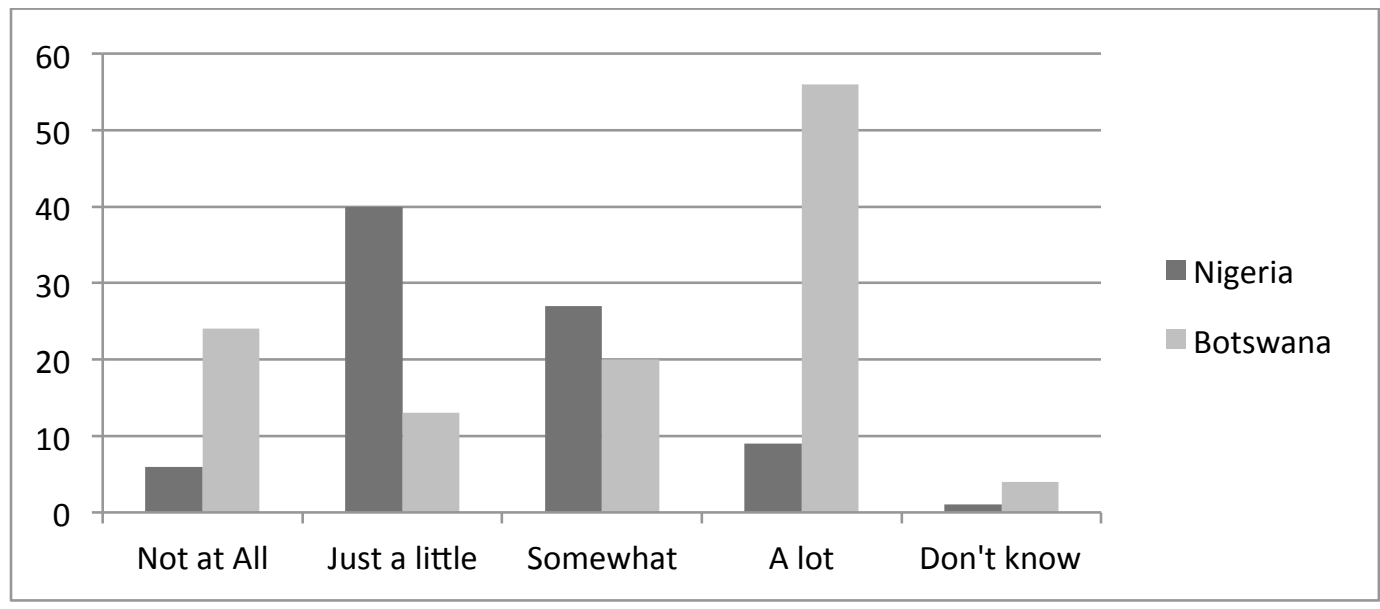

Figure 4.5 shows a great difference in the levels of trust that Botswana citizens and Nigerian citizens have towards their respective states. Whereas over 55percent of Botswana citizens trust their presidency a lot, more than 80percent of Nigerians trust

\footnotetext{
${ }^{27}$ The following chapter will deconstruct this statement. However, for the purposes of comparison, Botswana can be deemed more ethnically homogenous at least at the empirical level (Parsons, Neil and Robinson, James A (2005) "State Formation and Governance in Botswana”, AERC May 2003 Plenary Session, Nairobi, Kenya)
} 
theirs somewhat, a little or not at all. Trust can also be extended to public servants and government officials and vice versa. When I was in Botswana, I went to the National Archives and had to pay P70 (\$10) but had a P100 note. The lady did not have any change and told me that it was ok, I could pay the money the next time I come to the National Archives. It wasn't a lot of money, but she could have lost her job if records showed money was missing for a service provided. It just shows how much trust exists in Botswana between citizens and government officials. Another measure of trust is the prevalence and existence of corruption.

When asked: "In the past year, how often, if ever, have you had to pay a bribe, give a gift, or do a favor to government officials in order to: Get a document or a permit? " the respondents from Nigeria and Botswana greatly differed. Figure 4:6 shows the percentage of respondents who paid bribes to government officials for documentation and permits.

Figure 4:6 Percentage of Respondents who paid bribes to government

\section{officials}

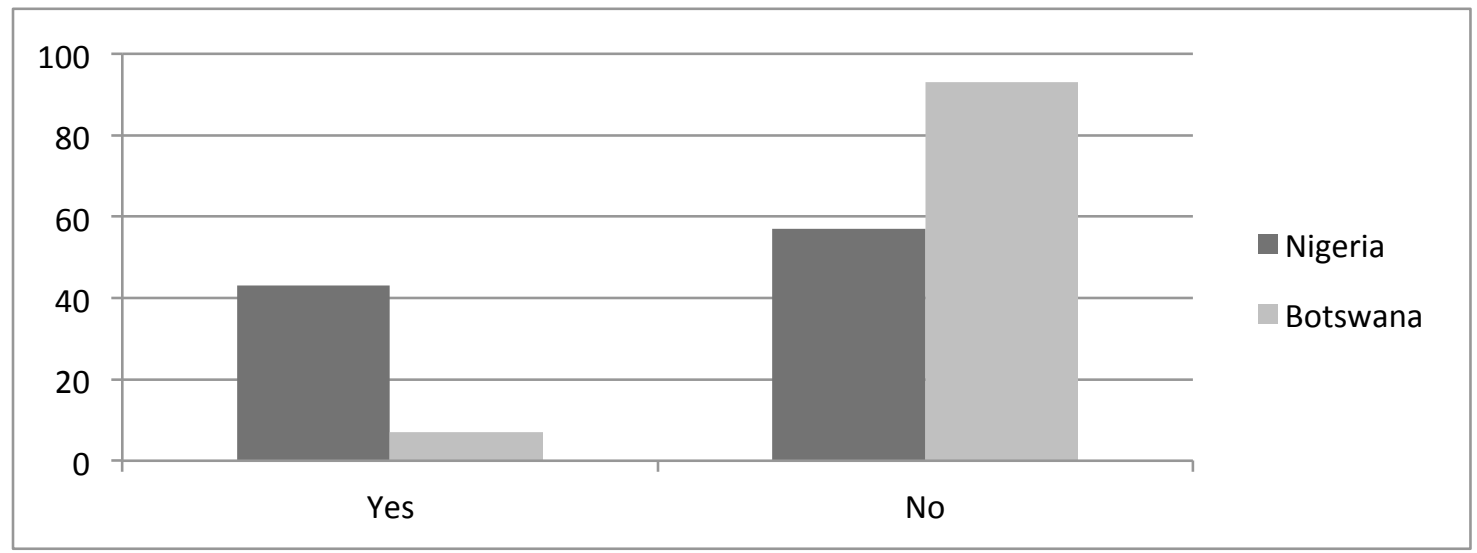

Source: Own, adopted from Afrobarometer, 2012 
Figure 4:6 reflects an overwhelmingly corrupt political culture in Nigeria, with almost half of the respondents from the country admitting to paying bribes in order to get access to documents and permits. This shows the propagation of informal patronage networks that exist in Nigeria which are not as prominent in Botswana.

As Woods (2012) notes, the serious dilemmas that Nigeria faces today are a result of values established in the pre-colonial era which conflict with those established during colonialism. Political culture in Nigeria is characterized by clientelism, specifically neopatrimonialism (Kaiser, 2005). According to Kaiser (2005) neopatrimonialism is a term used for patrons using state resources as a mechanism of guaranteeing the allegiance of clients in the population. The "patron" grants favors to his "clients" otherwise denied to others, in order to buy their loyalty. Such informal patron-client relationships can then penetrate various levels of state structures. In oil-exporting countries, a president may grant his clients privileged access to oil contracts and tenders, in exchange for their support. Similarly, as reflects in Figure 4.6, in exchange for basic social services, citizens have to pay officials bribes. This practice summons corruption, and it usually results in the larger society being deprived because the favors benefit a select few (Salisu, 2002).

An added layer to neopatrimonialism in Nigeria is that patrons are generally linked to clients by ethnicity and religion. The difficulty with neopatrimonialism is that it may weaken or supplant the bureaucratic structure of the state. This is because only those with connections have the real power, not necessarily those who hold higher positions. Neopatrimonialism as a result undercuts political institutions and the rule of law. Nigeria's undeveloped civil society guarantees that the state maintains control over 
economic pursuits, individual actions, religious activities and political participation of Nigerians. According to $\mathrm{Wood}^{28}$, this characteristic reinforces clientelism and restricts the viability of democratic reform.

In Nigeria there exists a tension between modernity and tradition. However, instead of emerging as a strong modern nation, Nigeria circumscribed its capability to reach that goal. This was due to the subservience of its economic position as a colony albeit being a major producer of oil. Upon independence, modernity was thwarted by ethnic-based military conflicts and personalized, corrupt leadership practices. The independence movement was a tension between reestablishing pre-colonial roots that emphasized communal accountability and creating a new state with proactive liberal ideals.

Yet another conflict characteristic which fashions Nigeria's peculiar political culture is religious conflict. According to Lapidus (2002) Nigeria's encounter with Islam dates back to the $9^{\text {th }}$ century, where the religion began to influence northern Nigeria, at first coexisting with native religions, and finally supplanting them. Christianity arrived much later, spreading rapidly and efficiently via European missionaries. Religion has had a polarizing effect in Nigeria, which has convoluted the country's political development and democratic aspirations. One instance is the Muslim's general endorsement of sharia, or religious law, as a valid part of political authority, to the dismay of Christians. This is an ongoing debate and has isolated incidence of religious conflict and terrorist attacks. Religious conflict in Nigeria is exacerbated by geographical influences, with the north of

\footnotetext{
${ }^{28}$ http://phs.prs.k12.nj.us/ewood/sources.html Accessed September 13, 2012
} 
the country dominated by the largely Muslim Hausa/Fulani and the Kanuri, and the southwest and southeast dominated by the Yoruba and the Igbo respectively (Wood, 2012). The south also consists of a variety of small minority groupings particularly in the Niger Delta region. Unlike the north, the south is largely Christian. This demographic configuration creates a fragile fault-line, the Middle Belt, an area characterized by a mix of both Muslims and Christians and a volatile hotspot for religious conflict (Murdock, $2012)^{29}$

The main differences between Botswana and Nigeria's economic and political development can therefore be attributed to variations in political cultures. Botswana's are based on trust, dialogue and consensus, while Nigeria's political culture is characterized by are the informal institutions that lack of trust, corruption and violence. This analysis of political culture can also be extended to other cases in sub-Saharan Africa.

\section{CONCLUSION}

This chapter aimed to show that there are cultural reasons for Botswana's experience with political development that account for its economic success and institutional quality. It understood Botswana's political culture in evolutionary terms, as a population phenomenon that evolved through a process of selection and retention of variation of beliefs and the behavior they give rise to. It argued that Botswana's contemporary political culture has been the result of centuries of political socialization particularly within the context of Tswana customs and traditions. This is reflected in the

\footnotetext{
${ }^{29}$ http://www.globalpost.com/dispatch/news/regions/africa/nigeria/120515/nigeria-jos-sectarian-violence
} 
country's cultural foundations within institutions like the kgotla in pre-colonial times that were perpetuated into the post-colonial state due to a limited engagement with the colonial administration during the time of British occupation. Botswana's political culture is one that is equilibrium between traditional roots that esteemed mutual criticism and dialogue over violence, as well as a ready embrace of the liberal paradigm that reveres civil liberties. Botswana's cultures thus a mixture of the old and the new creating a balance.

Botswana's traditional political culture provided the foundation for a democratic culture post-independence. The country's elite political culture has three tiers: pragmatism, dialogue and mutual criticism as well as consensus. Pragmatism allowed the elite to make the best decisions based on the resources and context at hand, and reflected the foundations of modern rational-legal authority. Its culture of dialogue and mutual criticism reflected a desire to use words and diplomatic channels as opposed to resorting to arms when settling disputes. It also provided for participation, accountability and transparency among various stakeholders. Lastly, its political culture of consensus reflects its egalitarian principles, extending equal rights and opportunities to its elements.

This research viewed individual views on authority and the state as greatly reflective the aggregate culture of the society. This constituted the country's mass political culture. In general, Botswana citizens reflect a great deal of apathy towards the politics of their country. However, those that do participate in the political process greatly reflect a tremendous endorsement of the state. According to Afrobarometer data, Botswana citizens greatly esteem civil liberties and personal freedoms as key constituents 
of democracy. Furthermore, they greatly show support for democracy, reject the oneparty state system, military rule and dictatorships. However, this research views mass political culture more as a facilitator of institutional quality rather that a key source. This is mainly it did not observe significant difference in the variation in mass political cultures across Africa. A non-scientific survey of Afrobarometer data shows that they define democracy in more of less the same way as other African countries. For example, nearly 70percent of Nigerians endorsed democracy as preferable to other forms of rule, thus also reflecting a high preference towards democracy. This is therefore not a cultural attribute of Botswana citizens alone. It however facilitates elite political culture, which it deems as a more real source of institutional quality.

In conclusion, the elite political culture of Botswana, coupled with the support of the masses, provided the foundation for good governance in Botswana thus contributing to its institutional quality. The following chapter will interrogate the role of ethnicity and identity management in Botswana's institutional quality. 


\section{CHAPTER FIVE:}

\section{ETHNICITY AND IDENTITY MANAGEMENT AS A SOURCE OF INSTITUTIONAL QUALITY IN BOTSWANA}

\section{Introduction}

This chapter addresses the third and final endogenous source of institutional quality in Botswana - ethnicity and identity management. One key reason cited for the relative instability and inability of African countries developing economically is the colonial legacy that left most states ethnically heterogeneous. In their seminal study, Easterly \& Levine (1997) revealed that the growth rate of GDP per capita is inversely related to the degree of ethnic fractionalization in a society. They demonstrated that ethnic diversity accounts for the limited and negative economic performance that African countries have faced since independence. Their point of departure was the relative optimism that was characteristic of the 1960s in Africa, the decade when most African nations gained independence. Although African countries were expected to surpass the growth rates of their East Asian and Latin American counterparts, one key factor impeded this goal: their levels of ethnic diversity.

African political boundaries were determined via a series of tragicomic negotiations in Berlin in 1884 among European powers, following an extensive "scramble for Africa". The result was the division of some ethnic groups, the lumping together of many others, and the exacerbation of pre-existing levels of ethno-linguistic diversity in Africa. In addition, colonization forged many new large ethnic clusters from previously smaller identity groups. Botswana's escape of the resource curse provides an 
anomaly to the African trend of low economic growth and political instability which is explained as having resulted from ethnic heterogeneity. As a result, it is not far-fetched to assume that a counter-truth exists in Botswana, primarily because at face value, Botswana has the markings of an ethnically homogenous state. Over 78percent of the population speaks Setswana and nationally the citizens are known as Batswana, a noun derived from the Tswana ethnic group. This hints at the possibility of high levels of ethnic homogeneity. However, upon closer inspection, it becomes clear that Botswana is actually a result of a social experiment by early Tswana elite, implemented to pragmatically manage the perils of ethnic diversity and heterogeneity such as ethnic conflict and tribalism. This elaborate scheme was an assimilation policy that transformed Tswana identities and activated new norms within Tswana society.

This chapter addresses how identities in Botswana were transformed and managed i.e. "constructed," through the pre-colonial, colonial and post-colonial period, in such a way that today they provide an example of peaceful coexistence. The Botswana case has been cited as an anomaly because not only has it escaped the economic resource curse, but also because it avoided the autocratic resource curse and the curse of violent conflict that most developing resource-rich countries have faced. As a result, Botswana exhibits three key indicators of institutional quality: economic development, democracy, and peace and stability. On the surface, Botswana seems like a discernibly ethnically homogenous society. Over 80percent of the population speaks Setswana at home, and with the exception of the BaSarwa identity group, access to resources brought about by the country's diamond wealth have been accessible universally to Botswana citizens, 
regardless of ethno-linguistic background (Andersson and Janson, 1997). However, upon deeper analysis, it is clear that this assumption is misguided, as the Botswana case illustrates a peculiar case of identity assimilation. Paradoxically, this assimilation accounts for peaceful coexistence in Botswana albeit at the expense of "minority" 30 cultures. The extent to which the country is "homogenous", linguistically at least, is a reality created by colonial and post-colonial authorities. It is a classic case of how social construction of ethnic categories emerged from an interaction between fluid identity groups with their rulers. Hence, this chapter identifies mostly with the constructivist theory of ethnic and identity formation.

Blagojevic (2009) maintains that ethnic conflict occur as a result of the convergence of specific sets of factors and conditions. These situations could include structural crises, presence of historical recollections of inter-ethnic grievances, institutional factors that promote ethnic prejudice, and manipulation of historical memories by political entrepreneurs to evoke fear, resentment and hate toward the "other" and an inter-ethnic competition over resources and rights. This dissertation finds this model particularly convincing, and also agrees with the counter-argument that when such factors and conditions are absent, the non-occurrence of ethnic conflict can be observed.

The goal of this chapter is to determine the role of ethnic dynamics in Botswana in institution building and subsequently in assisting its escape from the resource curse. It will attempt to uncover why Botswana has not been susceptible to the negative effects of

\footnotetext{
${ }^{30}$ The word "minority" in this instance bears no numerical significance as is described later.
} 
ethnic dynamics that are prevalent across sub-Saharan Africa. The chapter is divided as follows. First, it will outline some of the key conceptual frameworks of the identity management with a focus on constructivism. Through a close longitudinal examination of Botswana's pre-colonial, colonial and post-colonial ethnic history, the research found that although Botswana is as ethnically diverse like any other country, the state "managed" the identity of the country in a way to mitigate the negative impacts otherwise associated with ethnic heterogeneity. This in turn made the country more stable than would be otherwise expected.

The chapter will first provide a review of literature on the impact of ethnic dynamics on development, democracy and peace and stability. It will then look at the ethnic make-up of Botswana, paying close attention to how Botswana differs from other African states and resource exporting countries.

\section{CONCEPTUAL FRAMEWORK OF ARGUMENT}

\section{Ethnicity and Identity: Definitions and Perspectives}

Ethnicity has been one of the most contentious terms to characterize and define with varying perspectives accounting for the strength of ethnic identity. A myriad of definitions and theories of how ethnicity can be understood have emerged over the last decades. According to Hutchinson and Smith (1996), the term "ethnicity" has its English origins connected to the term "ethnic," used to reference collectives of social organization such as bands, tribes, races or peoples. However, during colonial times, the 
term evolved into a dichotomy of "Us" and "Them" with the former being viewed as the majority non-ethnics and the "Them" viewed as "ethnic." Concepts related to the term have developed along with the analysis of ethnicity, including ethnic identity, ethnic origin, ethnocentrism, and ethnicism (Hutchinson and Smith 1996:4-5).

Early accounts of ethnic identity or origin used it as a reference point to an individual's ancestral heritage. As Berreman (1972) argues, ethnicity is but one level of social stratification that is distinct from race or class. Ascribed from birth, ethnicity however normally defines its cultural characteristics itself. However, ethnic classifications are usually defined by outside groups to stereotype and oversimplify cultural processes.

This dissertation adopts Chandra (2012)'s rendering of ethnic groups as subsets of categories in which descent-based attributed are necessary for membership. According to Hutchinson and Smith (1996:6-7) \{in Baumann, 2004:1\} the six main attributes of an ethnic group are:

“....a common proper name, to identify and express the "essence" of the community; a myth of common ancestry that includes the idea of common origin in time and place and that gives an ethnie a sense of fictive kinship; shared historical memories, or better, shared memories of a common past or pasts, including heroes, events, and their commemoration; one or more elements of common culture, which need not be specified but normally include religion, customs, and language; a link with a homeland, not necessarily its physical occupation by the ethnie, only its symbolic attachment to the 
ancestral land, as with diaspora peoples; and a sense of solidarity on the part of at least some sections of the ethnie's population."

This list is adopted throughout this chapter as a reference for distinguishing between one ethnic or sub-ethnic group from another and gives each group individual characteristics.

Three theoretical perspectives have dominated the literature on ethnicity: primordial, instrumental and constructivist (Chandra, 2012). The primordial theory of ethnic identity argues that there is a biological link between members of the same ethnic group and assumes that this identity is hard to remove from. The instrumental identity theory places an emphasis on the role of ethnic entrepreneurs who heighten the importance of identities in order to lay claim to government resources, gain a greater number of recruits to a particular identity and increase their personal power. The constructivist perspective proposes that ethnic identities are in a constant process of construction and redefinition and as such are highly dependent on a variety of factors. It contends that ethnic identities arise from a "dense web of social interactions." Constructivists opine identities as products of historical occurrences, often recent, even when they are presented as old (O’Neil, 2013). Among the criticisms leveled at the constructivist perspective of ethnic identity are that the claims associated with this theory tend to be both vague and applicable to only a single, specific setting. Although a lot about the Botswana case can be viewed through the lens of the primodialist perspectives, whereby there are organic links and bloodlines shared within the varying identity groups, as well as through the instrumentalist perspectives, as a result of grand political strategy, 
this dissertation is of the persuasion that it is best understood by viewing ethnicity as a product of human agency. As will be illustrated in this chapter, in Botswana, commonalities such as language, cultural practices and political organization became woven into the consciousness of shared identity through an elaborate post-colonial assimilation policy thus greatly reflects the constructivist understanding.

\section{Ethnic Heterogeneity and Development}

Various indications of how ethnic diversity affects economic growth have been posited including low public goods provision (Habyarimana et al, 2007); inferior government performance (La Porta,1999); low school attainment and higher market distortions captured by the black market premium (Goren, 2013). Montalvo and ReynolQuerol (2005) argue that ethnically diverse societies have a higher probability of ethnic conflicts and civil war which in turn negatively impact investment. They maintain that ethnic diversity generates high levels of corruption and deters the diffusion of technological innovations. Ethnic heterogeneity's effects are also exacerbated by the existence of non-renewable resources leading to the promulgation of patron-client relationships as well as violent conflict over resources along ethnic lines (Collier and Hoeffler 2000; Ross 2004).

Ethnic diversity and heterogeneity has been linked to a plethora of effects ranging from conflicts of preferences, racism, prejudices which often lead to suboptimal policies as we as to the oppression of minorities with the possibility of descent into political instability or civil war (Alesina and La Ferrara, 2004). Habyarimana et al (2007) identify 
a number of mechanisms in which ethnic heterogeneity leads to the impediment of both human and economic development stemming from an undermining of the provision of public goods. They argue that different ethnic groups have varying preferences for different types of public goods as a result of geographic concentration, linguistic and cultural differences. These inclinations range from the aspiration to have certain languages of instruction in schools to the ability to observe cultural and religious holidays. This variance of tastes among ethnic groups may facilitate for the underprovision of broader public goods. Furthermore, they argue that the effective delivery of public goods is expedited by sets of strategies for encouraging collective action that are available to co-ethnics to the exclusion of non-co-ethnics. On the one hand, this is due to efficacy. Homogenous communities usually draw on the commonality of culture, language giving them an advantage in public goods production. They share understandings about modes of interaction that facilitate for communal cooperation. This collective cultural material advances prospects for effective collective action e.g. ability to communicate strategies, that heterogeneous groups lack. On the other hand, this may be due to shared membership in a social network which the authors argue enables coethnics to identify and thus punish non-cooperators.

Lastly, Habyarimana et at (2007) identify a strategy selection mechanism and posit that individuals' cooperative behaviors are contingent on the ethnicity of the people with whom they are interacting. By employing a game theoretic framework, they illustrate a game in which contributing to a public good is a preferred strategy if and only if one believes that others will contribute. They argue that when individuals assume co- 
ethnics will cooperate and non-ethnics will not, these expectations will be self-fulfilling under the Nash equilibrium solution conception. Public goods production is reliant on expectations for reciprocal cooperation where shirking is reprimanded. Sanctioning produced norms and social institutions of cooperation and defector punishment thus creating a cooperative equilibrium. Such norms are assumed to exist exclusively within ethnic groups but not across them. An underlying assumption is that co-ethnic cooperation will be reciprocated under threat of sanctioning while cooperation with nonco-ethnics will not. As a result the provision of public goods will be advanced in homogeneous communities, where the norm/social institution applies to everyone, than in heterogeneous communities, where potential cooperating partners are sometimes excluded. This dissertation reflects some of Habyarimana (2007)'s logic on mechanisms of impeding development and argues that using this knowledge Botswana elites pragmatically paved a path to better ethnic management in order to confront the anticipated perils of ethnic heterogeneity. By promoting the concept of Tswanadom, they created and managed a fluid identity that would help them escape the perils of ethnic heterogeneity.

\section{Ethnicity and Resource Conflict}

The study of ethnic conflict follows a long tradition, coming to prominence in the post-World War II era. In a study, Fearon and Laitin (2003) identified no less than 59 ethnic wars between 1945 and 1999, consisting of a majority of the total number of civil wars. The study has since drawn analytic consideration in the aftermath of the Cold War, 
particularly following the Yugoslav Wars. These events were characterized by ethnic conflicts that escalated into violence and civil war, leading to academics including Huntington and Kaplan to predict a proliferation of wars driven by civilizational upheavals, tribalism, resource scarcity and overpopulation. However, ethnic conflict is by neither universal, nor constant over time. Instead, for the greater part, ethnically heterogeneous societies, in many countries coexist peacefully and those which engage in conflict experience long periods of fairly harmonious ethnic relations before and after periods of conflict (Caselli and Coleman, 2011). That has been the case in Botswana.

As recounted in detail in Chapter 2, ethnic cleavages are even more pronounced in cases where non-renewable natural resources constitute a significant portion of a country's national product. According to Klare (1999) the geography of conflict is currently skewed towards countries with large oil and gas reserves. Similarly, natural resources have been motives for violent secessionist movements as in Cabinda, Angola, Aceh, Indonesia and Biafra, Nigeria. As Esman (1994) contends, this comes about due to the assumption that when a constituent of a specific ethnic group seized control of the state, essential economic assets are soon transferred to the supporters of that community.

Collier and Hoeffler (2004) debated on whether it was greed or grievance that provided for a motive for violent conflict over the control of profitable geologic resources. The first of the two scenarios is one motivated by rebel greed and the potential for economic benefits. Combatants are roused by a material calculation of advantage, performing cost-benefit analyses to examine the benefits of joining a rebellion. However, in the grievance approach, rebellion is over issues of identity, such as religion, ethnicity 
and social class, as opposed to economics. This study assumes Keen (2012)'s assertion that both greed and grievance influence development of a conflict.

Blagojevic (2009) argues that ethnic conflict requires a smorgasbord of converging factors and conditions. These conditions could include significant structural crises, existence of historical memories of inter-ethnic grievances, institutional influences that stimulate ethnic intolerance, and manipulation of historical recollections by political entrepreneurs to evoke sentiments such as fear, resentment and hate toward the "other". In addition, inter-ethnic competition over resources and rights may exacerbate conflict. Figure 5.1 illustrates Blagojevic's claim.

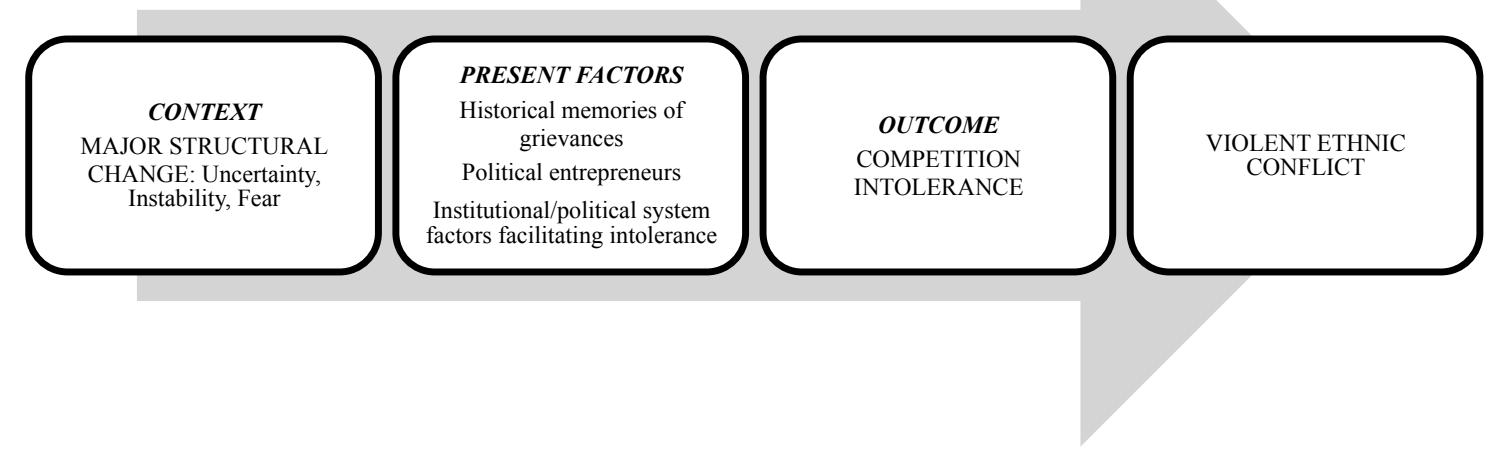

Figure 5.1 Causes of Ethnic Conflict (Source: Adopted from Blagojevic)

The history of Botswana has very few instances of violent conflict among ethnic or identity groups. Within the context of Figure 5.1, Botswana's history as observed in Chapter 3 experienced only minor structural change as a colony. In addition, its history is not a history of tribal and ethnic grievance. Most instances of violence have been instigated by agents external to the state as was the case in the Battle of Dimawe, which was an attack from the Boers, The first Matabele War, which was an attack from the 
Ndebeles and the Jameson Raid, a botched attack on the Transvaal Republic by

Rhodesian and Bechuanaland police led by colonial statesman Leander Starr Jameson.

However, this is not to say that some identity clusters have not been marginalized.

Figure 5.2 Causes of Ethnic Conflict: Theoretical Elements

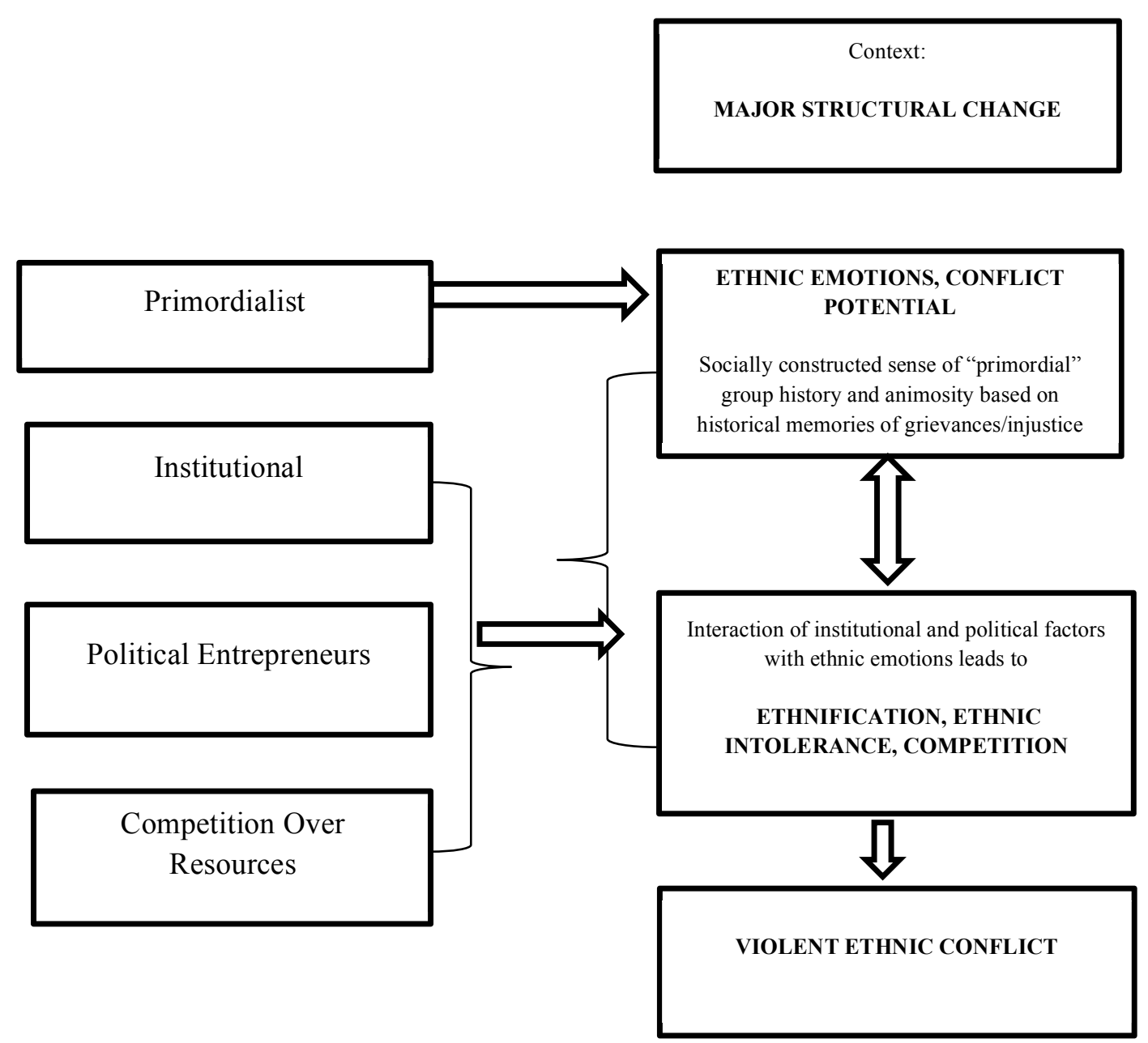

As depicted in Figure 5.2, Blagojevic (2009) argues that the primodialist approach accounts for the role of emotions and the conflict potential of ethnicity. She states that the existence of ancient hatred among ethnic and cultural groups and the urge to define "fear" 
and reject the "other" is natural and primal, dating back to human's remotest ancestors and their animal predecessors. According to this view, human beings are conditioned towards exhibiting xenophobic tendencies and intolerance, even to a greater degree than they are to be influences by liberal politics of interest. She illustrates the "institutional"; "political entrepreneur" and "competition over resources" approaches as interfaces of institutional and political factors with ethnic sentiments that result in ethnification, ethnic intolerance, competition and ultimately violent conflict. For the instrumental approach Blagojevic (2009) cites Crawford who argues that the functionality of state institutions affects the fate of identity politics which inspire violent conflict. She claims that states are capable of guiding identity politics into diplomatic political competition provided that credible assurances are made to shape and uphold agreements made among culturally demarcated actors. Conversely, political mobilization along ethnic lines is stimulated where the state's administrative institutions and legal structures allocate resources on the basis of ethnicity. Under the political entrepreneurial conceptual framework, Blagojevic maintains that a "perfect" condition in which political entrepreneurs can manipulate ethnic emotions for the purpose of mobilizing groups for their own political purposes, occurs when instability and uncertainty arise from major structural changes. This is because the resultant institutions are inept to regulate inter-ethnic relations. Ethnic differences are thus exploited by politicians as they draw upon historical memories of grievances and embolden hatred in order to reinforce their authority. The dynamic that results between political entrepreneurs and their followers creates an inter-ethnic security dilemma. Finally, Blagojevic presents the "competition over resources" element. In this approach, resource scarcity allows the capitalization on the conflict potential of ethnicity 
by political entrepreneurs. Blagojevic tries to integrate these approaches to understanding ethnic conflict. In the case of Botswana however, the opposite can be said to be true. Instead of exploiting ethnic differences, Botswana's governing elite decided to use ethnic similarities as a unifying force in order to create a national identity based off of existing realities and histories. As a result, understanding of the Botswana case borrows from various inspirations and adaptations.

Caselli and Coleman (2011) adopted the UNDP measure of "ethnic distance" in ascertaining some factors that could lead to conflict from those who do not. According to UNDP (2005), "ethnic distances" describes the degree of understanding and intimacy between members of different identity groups, which is manifested in readiness to establish more or less close social relationships with members of this group, or lack thereof. Caselli and Coleman (2011) view natural resources as providing an incentive for subsets of agents to form groups to wrest control of these assets from the rest of the population. They argue that the victorious group allocates resources to ensure the exclusion of non-members because infiltration would result in less dividends being shared among the original group. The authors' key idea is that when groups are formulated along ethnic lines, ethnic identity becomes a marker to recognize potential infiltrators. They argue that ethnicity provides a technology for group membership and exclusion, which is used to avoid indiscriminate access to the spoils of conflict.

Caselli and Coleman (2011) define ethnic distance as the costs to be borne by a member of one group to successfully pass him or herself as a member of another group. Hence, the assumption is that ethnic distance is greater when there are differences in skin 
color and other physical characteristics that make passing for a member of a specific group all but impossible. They argue that in instances of religious diversity, ethnic distance is relatively high. They however view language as a weak source of distance as potential infiltrators can easily learn to speak the other's language. Therefore, , ethnic cleavages marked by a shared sense of identity or history, unsubstantiated by differences of race, religion or language, are usually associated with the lower levels of ethnic distance. Their ethnic distance theory helps explain the persistent disadvantage of African-Americans in the United States and apartheid in South Africa based on pigmentation and the genocide in Rwanda based on complexion and body size. However, according to their theory religious conflicts as exemplified by and language barriers as exemplified by the massacre of Haitians who failed to pronounce the word "perejil" correctly in the Dominican Republic, lead to less levels of conflict as these are easier for people to "pass."

Caselli and Coleman's argument is of particular relevance to this chapter as it argues that Botswana elite implemented an assimilationist policy in order to artificially reduce the "ethnic distance" in Botswana society. This had the impact of creating peace, albeit artificially, with the policy being successful for removing discernible ethnic differences such as language difference. This created a society reminiscent of a homogenous state. The main strategy was to create artificial "co-ethnics" in order to ameliorate the perils of ethnic diversity that would otherwise lead to conflict and the undermining of goods and service provision. The following sections will describe Botswana's primordial ethnic groupings and how they evolved assimilated into a new constructed identity category. 


\section{ETHNICITY AND IDENTITY MANAGEMENT IN BOTSWANA}

\section{Ethnicity and Identity Groups in Botswana: Description}

The ethnic composition of Botswana is highly subjective and mostly a reflection of who is asked and how they determine what an ethnic group is and what is not.

According to Nyati-Ramahobo (1991), there are about 50 distinct indigenous groups in Botswana speaking about 26 languages. The Khoisan are classified into eleven main ethnic groups and speak about 23 languages and dialects. The rest of the languages and ethnic groups are Bantu, with eight of them speaking Setswana as their mother tongue. Currently the only comprehensive list of identity groups in Botswana is provided by the Reteng 2005 as is depicted in Tables 5:1; 5:2 and 5:3:

Table 5.1 Tswana Tribes Bantu (The recognized tribes)

\begin{tabular}{|l|l|}
\hline Tribe & Population (2001 census) \\
\hline Bakgatla & 108000 \\
\hline Bakwena & 60000 \\
\hline Bamalete & 20000 \\
\hline Bangwaketse & 40000 \\
\hline Bangwato & 18000 \\
\hline Barolong & 47000 \\
\hline Batawana & 2000 \\
\hline Batlokwa & 10000 \\
\hline Total & $\mathbf{3 0 5 , 0 0 0}(\mathbf{1 7 . 9} \%)$. \\
\hline
\end{tabular}

Source: Reteng 2005 
Table 5.2: Marginalized Bantu Identity Groups

\begin{tabular}{|c|c|}
\hline Tribe & Population \\
\hline 1. Babirwa & 69000 \\
\hline 2. $\quad$ Baboloungwe* & 40000 \\
\hline 3. $\quad$ Bagciriku & 5000 \\
\hline 4. $\quad$ Bahurutshe & 9000 \\
\hline 5. Bakaa & 18000 \\
\hline 6. $\quad$ Bakalanga & 276000 \\
\hline 7. $\quad$ Bakgothu & 19000 \\
\hline 8. $\quad$ Bakgwatheng* & 12000 \\
\hline 9. Bakhurutshe & 18000 \\
\hline 10. Bakwangali & 2000 \\
\hline 11. Banabjwa & 9000 \\
\hline 12. Bangologa * & 7000 \\
\hline 13. Baphaleng * & 14000 \\
\hline 14. Barotsi & 4000 \\
\hline 15. Bashaga * & 189000 \\
\hline 16. Batalaote & 5000 \\
\hline 17. Batlhware & 23000 \\
\hline 18. Batshweneng & 8000 \\
\hline 19. Batswapong & 58000 \\
\hline 20. Vekuhane & 19000 \\
\hline 21. Hambukushu & 49000 \\
\hline 22. Ndebele & 2000 \\
\hline 23. ovaHerero & 29000 \\
\hline 24. ovaMbanderu & 30000 \\
\hline 25. Wayeyi & 65000 \\
\hline Total Bantu & 974000 \\
\hline
\end{tabular}

Source: Reteng 2005 
Table 5.3 Marginalized Khoisan (BaSarwa)

\begin{tabular}{|c|c|}
\hline Tribe & Population \\
\hline ||Gana & 8000 \\
\hline |Gwi & 5000 \\
\hline$\neq \mathrm{H} v \alpha$ & 3000 \\
\hline Ju|'hoan & 5000 \\
\hline Shua & 7000 \\
\hline Khwedam & 8000 \\
\hline Naro & 10000 \\
\hline$\neq K \xi \square \alpha v \| \varepsilon \iota v$ & 4000 \\
\hline Tsowa & 5000 \\
\hline !Xóo & 850 \\
\hline Kua & 600 \\
\hline Nama & 1500 \\
\hline Total & 57500 \\
\hline$*$ = Bakgalagadi $=$ Total is 272000 & \\
\hline
\end{tabular}

\section{Source: Reteng 2005}

According to these Tables 5:1, 5:2 and 5:3, when grouped together, BaTswana are the largest ethnic group in Botswana. However BaKalanga are the largest tribal group. However, they do not form a majority ethnic group, as they only account for 17.9percent of the total population. In this dissertation, the term "tribe" will be used to describe a social group that existed before the development of the post-colonial state and is largely based on kinship and descent. Hence, BaTlokwa and BaKwena would be described as different tribes, but as one ethnic group, BaTswana. The term "ethnic group" will be 
defined along ethno-linguistic lines. Therefore groups that speak the same language as a first language will be considered "co-ethnics". With this designation, the term BaTswana would be used to describe all "tribes" who speak Setswana as a first language, as is done in Botswana. As ethnic groups in Botswana are delineated along linguistic fault lines, the rest of the identity groups listed in Tables 5.2 and 5:3 are interchangeably considered both tribes and ethnic groups.

It is important to note that although BaKwena, BamaLete, BaNgwaketse, BaTawana and other tribal groups that speak Setswana as their primary language are significantly less in numbers than BaKalanga, it is BaKalanga who are considered as a minority ethnic group in Botswana and not the Tswana groups. This is because in Botswana, the term minority has very little numerical value but bears considerable political significance. As Nyati-Ramahobo (1991) argues, from an ethnic and linguistic viewpoint, it is inaccurate to speak of majority and minority groups, but rather of marginalized versus non-marginalized linguistic and ethnic groups in Botswana. This study simply distinguishes between those who speak Setswana as mother tongue from those who speak it as a second language. Each of the 8 indigenous groups whose mother tongue is Setswana, are thus considered BaTswana, a majority group. As a result, BaKalanga, which is numerically the largest single identity group in Botswana, will be considered a "minority group" due to its suboptimal political influence and due to the fact that its constituents speak Setswana as a second language. The tribes which speak Setswana as a first language are listed alphabetically in Table 5.1 as BaKgatla, BaKwena, BamaLete, BaNgwaketse, BaNgwato, BaRolong, BaTawana and BaTlokwa. 
In Botswana, in terms of national identity, both first-language Setswana speakers and second language Setswana speakers embrace the Tswana culture as their national heritage in accordance with the assimilationist model, which will be described in greater detail later in this chapter, and consider themselves "BaTswana ${ }^{31}$ ". In this dissertation however, I will describe the national identity as "Botswana citizenship" and its constituents as "Botswana citizens" to avoid confusion.

The following sections will discuss the evolution of identities in Botswana from pre-colonial, through colonial and to post-colonial periods.

\section{Historical Ethnic Relations in Botswana: Pre-Colonial}

The Khoisan (BaSarwa) are commonly considered to have been the earliest inhabitants of territorial Botswana, with Bantu speaking populations arriving later. According to archeological evidence, the latter's settlement dates back to the era of the Bantu migration. Schapera (1953) argues that they the Tswana separated from the core body of Bantu-speaking peoples somewhere in the vicinity of the Great Lakes of East Africa in three series of migrations. The first series is represented today by the people collectively known as BaKgalagadi, who settled in the eastern, more fertile part of Botswana. The second migration was the ancestors of the BaRolong and BaTlhaping who settled south and west of Botswana. These two groups absorbed some BaSarwa (Khoisan) and BaKgalagadi predecessors, most of who later retreated before them into

\footnotetext{
${ }^{31}$ In most texts on the country, the term BaTswana refers to anyone who holds Botswana citizenship regardless of ethnicity, race, religion, tribe, language.
} 
the arid zones of the Kalahari Desert. The third and greatest migration brought the ancestors of all the other Sotho tribes. In his ethnographical study, Ian Schapera (1953:3) states that the Tswana are one of three major divisions into which ethnologists and linguists usually classify as the Sotho group of Bantu- speaking people of central Southern Africa. The other two are distinguished as the "Southern Sotho" of modern day Lesotho, and the "Northern, Eastern or Transvaal Sotho" of modern day Transvaal, South Africa. The Tswana correspondingly are sometimes termed "Western Sotho".

The main Tswana ruling groups are thought to have established themselves in Botswana in the 18th century. These included the BaKwena, BaNgwaketse and BaNgwato. According to Bennet (2002) these dominant Tswana groups displaced, absorbed, or subjugated the rest of the ethnic groups when they first established themselves in the territory. By this view, the BaSarwa who were seen as having been preagricultural hunter-gatherers since time immemorial began losing out steadily to more advanced groups, first the BaKgalagadi and then BaTswana.

The period of 1815 to 1840 was a period of widespread chaos and warfare among indigenous ethnic communities in southern Africa. Historically this period is referred to as the Mfecane $e^{32}$ (Zulu) or Difaqane (Sesotho). As King Shaka transformed the militaristic Zulu Kingdom, his forces caused a wave of warfare and disruption to sweep to other peoples and territories, north of the Zulu Kingdom which is modern day

\footnotetext{
${ }^{32}$ Series of Zulu and other Nguni wars and forced migrations in the early 19th century that changed the demographic, social, and political configuration of southern and central Africa. Set in motion by the rise of the Zulu military kingdom under Shaka, it took place in the context of drought, social unrest, and competition for trade. Ethnic group was set against ethnic group in an ever-increasing radius, resulting in the creation of large refugee populations as well as the establishment of new kingdoms under the Basuto, Gaza, Ndebele, and Swazi peoples.
} 
Botswana. This greatly altered the configuration of power among Tswana and nonTswana populations in that the Tswana chiefdoms were quick to recover and were successful in rapidly incorporating new groups within their society in a process of snowball growth. The non-Tswana groups were not so lucky. The BaSarwa whose main livelihoods were hunting and gathering were relegated to the periphery of Tswana merafe (populace) and forced to rely on foraging..

As discussed in Chapter 3, pre-colonial Botswana was made up of a constellation of Tswana-ruled kingdoms and proto-states referred to as merafe (singular morafe). In most cases, merafe were multi-ethnic clusters, with the larger, the Ngwato and the Tawana states being more heterogeneous than the others. A complex system of hierarchy existed in the various groups and the status of those considered non-Tswana, varied. The main categories were commoners such as the BaKalanga, "foreigners" such as the BaHerero, and serfs such as the BaSarwa and many BaKgalagadi. In order to exercise rights, one had to be a member of an organized ward as opposed to a subject of any given morafe. This designation greatly excluded a majority of BaSarwa.

BaKalanga are currently Botswana's largest tribal group in numerical terms, however, they are generally considered Botswana's largest minority group in political terms as a result of Tswana subjugation. Historically, the BaKalanga are considered "western Shona" corresponding to the Shona people of Zimbabwe with whom they share common ancestry from the Shona states of Mapungubwe, Great Zimbabwe, Torwa and Rozvi states. According to Tlou and Campbell, as these states lost power, gradual 
migration occurred of the BaKalanga westward toward Khami. They argue that they settled permanently in the area that is now a part of eastern Botswana.

Zibani Maundeni argues that an alternative explanation of how primordial identity groups in Botswana emerged comes from the notion of totems. Totemism is a central concept in southern African culture and religion and is one of the longest lasting cultural traditions. A totem is defined in the Merriam-Webster dictionary as "a being, object, or symbol representing an animal or plant that serves as an emblem of a group of people, such as a family, clan, group, lineage, or tribe, reminding them of their ancestry (or mythic past $)^{33}$." Totems exist in almost every culture in southern Africa. In most cultures a person may not eat the meat or any food derivative of their totem. Secondly, they are not to marry any person of the same totem. Thirdly, they associate their totem with good luck and fortune and usually a person thanks via the reciting of poetry about the person's particular totem. According to Schapera (1953), totemism is patrilineal but nonexogamous. There are certain myths as to how each totem came about. People could not kill or eat their totem, nor touch its skin; and should they inadvertently do so, they were to undergo a purification ceremony to avoid illness or other misfortune. It is also considered polite to address or greet a person by the name of his totem. Apart from these usages, and the belief in common origin, there is no special bond among members of a totem group. In many cultures, in Botswana, South Africa and Zimbabwe, totems are still highly revered. What makes totemism peculiar is that people adhere to their totems regardless of ethnic-linguistic or tribal membership. Whether a person is Shona from

\footnotetext{
${ }^{33} \mathrm{http} / / / \mathrm{www} . m e r r i a m-w e b s t e r . c o m / d i c t i o n a r y /$ totem
} 
Zimbabwe, Kalanga from eastern Botswana, from Lesotho or from South Africa, they

have a totem attached to their family name and lineage.

Table 5.4 illustrates the totems of the Sotho-Tswana clans.

Table 5.4: Botswana Tribes and Totems

\begin{tabular}{|c|c|c|c|c|}
\hline Tribe Name & Language & Country & Totem & Split from \\
\hline BaBirwa & Setswana & Botswana & Nare (Buffalo) & \\
\hline BaFokeng & $\begin{array}{l}\text { Sesotho, } \\
\text { Setswana }\end{array}$ & $\begin{array}{l}\text { Lesotho, South Africa } \\
\text { (North West, Free State) }\end{array}$ & $\begin{array}{l}\text { Mmutla, Kwena } \\
\text { (Rabbit/Crocodile) }\end{array}$ & \\
\hline BaFula & Sesotho & $\begin{array}{l}\text { Lesotho, South Africa (Free } \\
\text { State) }\end{array}$ & Kolobe (Wild Hog) & \\
\hline BaGananwa & $\begin{array}{l}\text { Sesotho sa } \\
\text { Lebowa }\end{array}$ & South Africa Limpopo & Tshwene Baboon) & BaHurutshe \\
\hline BaHlakwana & Sesotho & $\begin{array}{l}\text { Lesotho, South Africa (Free } \\
\text { State) }\end{array}$ & Tlou (Elephant) & \\
\hline BaHurutshe & Setswana & $\begin{array}{l}\text { Botswana, South Africa } \\
\text { (North West) }\end{array}$ & Tshwene (Baboon) & \\
\hline BaKgaga & $\begin{array}{l}\text { Sesotho sa } \\
\text { Lebowa }\end{array}$ & South Africa (Limpopo) & Kwena (Crocodile) & BaKwena \\
\hline BaKgalagadi & Setswana & Botswana & & \\
\hline $\begin{array}{l}\text { BaKgalagadi } \\
\text { BaBoalongwe }\end{array}$ & Setswana & Botswana & & \\
\hline $\begin{array}{l}\text { BaKgalagadi - } \\
\text { BaNgologa }\end{array}$ & Setswana & Botswana, Namibia & & \\
\hline $\begin{array}{l}\text { BaKgalagadi - } \\
\text { BaPhaleng }\end{array}$ & Setswana & Botswana & & \\
\hline $\begin{array}{l}\text { BaKgalagadi - } \\
\text { BaShaga }\end{array}$ & Setswana & Botswana & & \\
\hline BaKgatla & $\begin{array}{l}\text { Sesotho, } \\
\text { Setswana }\end{array}$ & $\begin{array}{l}\text { Lesotho, Botswana, South } \\
\text { Africa }\end{array}$ & $\begin{array}{l}\text { Kgabo, (Eagle; } \\
\text { Monkey) }\end{array}$ & BaHurutshe \\
\hline BaKhurutshe & Setswana & Botswana & $\begin{array}{l}\text { Tshwene/Phofu } \\
\text { (Baboon/Elands) }\end{array}$ & BaHurutshe \\
\hline BaKone & $\begin{array}{l}\text { Sesotho ba } \\
\text { Lebowa }\end{array}$ & South Africa (Limpopo) & $\begin{array}{l}\text { Scaly feathered } \\
\text { finch }\end{array}$ & \\
\hline BaKubung & Setswana & & $\begin{array}{l}\text { Kubu } \\
\text { (Hippopotamus) }\end{array}$ & BaRolong \\
\hline BaKwena & $\begin{array}{l}\text { Sesotho, } \\
\text { Setswana, } \\
\text { Sesotho sa } \\
\text { Lebowa }\end{array}$ & & Kwena (Crocodile) & \\
\hline BamaLete & Setswana & Botswana & Nare (Buffalo) & \\
\hline BaNareng & $\begin{array}{l}\text { Sesotho, } \\
\text { Setswana }\end{array}$ & & Nare (Buffalo) & \\
\hline BaNgwaketse & Setswana & Botswana & Kwena (Crocodile) & BaKwena \\
\hline BaNgwato & Setswana & Botswana & Phuti (Duiker) & \\
\hline BaPai & Sesotho ba & South Africa (Limpopo) & & \\
\hline
\end{tabular}




\begin{tabular}{|c|c|c|c|c|}
\hline & Lebowa & & & \\
\hline BaPedi & $\begin{array}{l}\text { Sesotho sa } \\
\text { Lebowa }\end{array}$ & & Noko (Porcupine) & BaKgatla \\
\hline BaPhalane & Sesotho & & Kwena (Crocodile) & BaKwena \\
\hline BaPhiri & Setswana & & Phiri (Hyena) & \\
\hline BaPhuting & Sesotho & & Duiker & \\
\hline BaPo & Setswana & & Kwena (Crocodile) & BaKwena \\
\hline BaRokologadi & Setswana & & Noko (Porcupine) & \\
\hline BaRolong & Setswana & & Tholo (Wildebeest) & \\
\hline BaSia & Sesotho & & katse (Wild Cat) & BaKgatla \\
\hline BaTau & $\begin{array}{l}\text { Sesotho ba } \\
\text { Lebowa }\end{array}$ & South Africa (Limpopo) & Tau (Lion) & \\
\hline BaTaung & $\begin{array}{l}\text { Sesotho, } \\
\text { Setswana, } \\
\text { Sesotho sa } \\
\text { Lebowa }\end{array}$ & South Africa & Tau (Lion) & BaHurutshe \\
\hline BaTawana & Batswana & Botswana & Tholo (Kudu) & BaNgwato \\
\hline BaTlhako & Setswana & South Africa & Tlou (Elephant) & \\
\hline BaTlhaping & Setswana & South Africa, Namibia & $\begin{array}{l}\text { Tholo ba nina } \\
\text { Tlhapi (Kudu/Fish) }\end{array}$ & BaRolong \\
\hline BaTlharo & Setswana & & Tshwene (Baboon) & \\
\hline BaTlhware & Setswana & & Tshwene (Baboon) & \\
\hline BaTlokwa & $\begin{array}{l}\text { Sesotho, } \\
\text { Setswana, } \\
\text { Sesotho sa } \\
\text { Lebowa }\end{array}$ & & $\begin{array}{l}\text { Noko, Nkwe, } \\
\text { Thakadu (Wild } \\
\text { Cat) }\end{array}$ & BaKgatla \\
\hline BaTloung & Setswana & & Tlou (Elephant) & \\
\hline BaTsatsing & & & Letsatsi (Sun) & \\
\hline BaTshweneng & $\begin{array}{l}\text { Sesotho, } \\
\text { Setswana, } \\
\text { Sesotho sa } \\
\text { Lebowa }\end{array}$ & & Tshwene (Baboon) & BaHurutshe \\
\hline BaTtswapong & Setswana & Botswana & hare or kgope & \\
\hline Makgolokwe & Sesotho & & phuthi (small buck) & \\
\hline Makgwakgwa & Sesotho & & & \\
\hline Makololo & & Zambia & Kwena (Crocodile) & BaFokeng \\
\hline Mapulana & $\begin{array}{l}\text { Sesotho ba } \\
\text { Lebowa }\end{array}$ & South Africa (Limpopo) & Tau (Lion) & \\
\hline BaKopa & $\begin{array}{l}\text { Sesotho ba } \\
\text { Lebowa }\end{array}$ & South Africa (Limpopo) & & \\
\hline BaKutswe & $\begin{array}{l}\text { Sesotho ba } \\
\text { Lebowa }\end{array}$ & South Africa (Limpopo) & & \\
\hline BaRoka & $\begin{array}{l}\text { Sesotho ba } \\
\text { Lebowa }\end{array}$ & & Tau (Lion) & \\
\hline $\begin{array}{l}\text { BaKwena Ba } \\
\text { MaThebe(AKA } \\
\text { BaNtwane) }\end{array}$ & Setswana & South Africa & $\begin{array}{l}\text { Kwena (Crocodile) } \\
\text { Tholo \& Kgabo }\end{array}$ & $\begin{array}{l}\text { BaNgwato, } \\
\text { BaRolong \& } \\
\text { BaKgatla }\end{array}$ \\
\hline
\end{tabular}

Source: Racionzer, 2013 page 3-4 
Maundeni's main argument against the notion of ethnicity in Botswana is that at some point in time all bearers of the same totem had the same origin. So if a person's totem in Zimbabwe is a lion, and another in Lesotho or Botswana is a lion, then he argues that at some point they originated from the same ancestor and hence constitute a blood tie that does not correspond with the current delineation of ethnic groups. In practice, in southern Africa, despite the perceived tribal/ethno-linguistic orientation, the same rules of totemism still apply, particularly those that surrounds issues of marriage. Despite a person being a Tswana, Sotho, Zulu, Shona, Kalanga or Ndebele, if their totem is the lion, they cannot marry each other. This research is of the view that the fluidity of totemism in southern Africa provided a structural basis for peaceful coexistence among otherwise diverse ethnic groups.

Pre-colonial Botswana set the stage for some of the identity undercurrents that would later characterize contemporary Botswana. BaKalanga became a minority because they were viewed as "foreigners" as their ancestry was external to the land that is now modern Botswana. BaSarwa and BaKgalagadi subjugation in Tswana society predated the creation of the Botswana state and hence were not products of any colonial enterprise. However, as will be seen in the following section, colonialism did further subjugate minority ethnic groups in Botswana further exacerbating Tswana hegemony. 


\section{The Transformation of Botswana Ethnic Identities and Attitudes during Colonialism}

The colonial period in Botswana was a period of transformation particularly in terms of consolidation of societal hierarchy among the various identity groups in the country. In most other parts of Africa, British colonial administrators employed 'divide and conquer' tactics in relation to ethnic groups, a situation blamed for contemporary ethnic violence and political unrest. This was not the case in the Bechuanaland Protectorate, where colonialists preferred to maintain the power of the chiefs as the most convenient form of government, thus maintaining the status quo. As they were larger, the colonialists opted to engage primarily with the Tswana groups and their efforts and interests were highly skewed thus.

The colonial period saw the consolidation of the Tswana identity and institutions as the dominant ones that would emerge in post-colonial Botswana. Attempts by minorities to resist Tswana power were actively swatted down, with the colonial government backing the Tswana chief, for the most part. The colonial administration generally viewed non-Tswana areas as outposts of South African and Rhodesian settler states (Bennet, 1999). Chiefs of relatively small merafe only on occasion managed however to achieve paramount status by accidents of geography, luck as well as careful diplomacy, which was the case of BaTlokwa and BaLete. The colonial administration relied heavily on the chiefs of Tswana tribes to administer their colony. This resulted in the inadvertent colonial practice of marginalizing smaller identity groups, albeit in a nonviolent manner. The colonial office deemed unacceptable the deliberate oppression or 
maltreatment of one ethnic group by another, an intolerance that could explain the peace and stability of Botswana today. However, nothing much was done to prevent such incidents were they to occur. For the greater part in practice colonial administrators shied away from becoming embroiled in internal inter-ethnic issues of ethnic subordination but accepted inhabitants rights to vary according to ethnic categories. This colonial practice thus further consolidated Tswana domination of smaller ethnic groups and further amalgamation of their minority status that had emerged during the Mfecane.

The colonial offices although they had their own prejudices, favored BaTswana groups for the strategic purpose of running the administration smoothly. However, certain commissioners did favor some minority groups such as BaKalanga. For instance, Rey described them in his private journals as "hard workers, wealthy and much better men in every way" when comparing them to BaNgwato, a Tswana tribe. Rey as a result provided funding for a Tati Training Institute in the area under the custodianship of K.T Motsete who had been seen by Ngwato Chief Tshekedi as a Kalanga separatist. However, the resident commissioner succeeding Rey, Arden-Clarke, did not share his views on the development of the protectorate and was anxious to restore good relations with the Tswana chiefs. The administration thus stopped support the Tati Training Institute's appeals for renewed American aid money, on which it was dependent, and it was forced to close in 1942.

The impact of colonialism can be viewed in the way certain spellings and pronunciations of words were adopted. For example, earliest European visitors tended to record words in forms which seem more like modern SeKgalagari (the language of the 
Kgalagadi) than modern Setswana. In particular, the famous Kalahari Desert's name is spelt in SeKgalagari. However, most official documents in Botswana today promote the Setswana forms as "more correct" (Parson, 1999). This promotion of Setswana forms is one ways in which BaKgalagadi have been continuously marginalized within Botswana society. Early journal entries of various Bechuanaland commissioners reflected some of the stereotypes of minorities that currently exist today in Botswana. Particularly, ArdenClarke is known to use the term "culturally degenerate Tswana" in reference to BaKgadagadi as well as the stereotype of BaKalanga being more educated and smarter than BaTswana. These attitudes still permeate Botswana society today.

The BaSarwa remain the most marginalized group in Botswana, a situation that emerged prior to colonialism. In fact, in 1887, the Colonial Office expressed considerable disquiet at the treatment of the BaSarwa, using the term 'slavery'. After the First World War, the League of Nations enquiry into slavery put the colonial administration on the defensive and it was tacitly agreed that whatever the status of the BaSarwa, it must be shown not to be slavery. In the 1930's the colonial office's actions pertaining to BaSarwa were at best ambivalent and can best be described within the context of the relationship between Charles Rey, Resident Commissioner from 1930 to 1937 and Chief Tshekedi Khama, the BaNgwato regent with whom he had many conflicts. Rey was not favorable to ethnic minorities but did pick up the issue of the status of BaSarwa serfs and hereditary servants as a strategic maneuver to undermine Tshekedi Khama and other chiefs. The administration, while denying that slavery existed, made a public declaration on the rights of the BaSarwa. Schapera (1955) noted that this declaration made no immediate practical 
difference to the position of the BaSarwa, though there was evidence of some genuine effort by at least some officials to prosecute the worst case of ill-treatment. In 1930 Tshekedi requested an official enquiry to clear up what he saw as misconceptions resulting in the 'Tagart report' which criticized Tshekedi and made some suggestions for how the position of the BaSarwa could be improved.

Rey's attitude to the BaSarwa was at best ambivalent. His public outburst about the uselessness of 'preserving a decadent and dying race, which is perfectly useless from any point of view", has widely been quoted to reflect this equivocality. Rey had no respect for the cultures of the BaSarwa, but he generally thought that individual BaSarwa should have the chance to escape servitude and become 'civilized' at the very least; he disapproved of their being actively ill-treated. Although rhetorically, Rey proclaimed strong action towards the plight of the BaSarwa, on the ground he was more preoccupied with more dramatic issues such as the flogging of Phinehas McIntosh at the behest of Tshekedi. This seemingly isolated incident of a white wagon builder with a reputation of philandering and public intoxication and charged in an African native court, caused much controversy leading to the deployment of British naval forces to the Kalahari desert and a colonial inquiry into Tshekedi's alleged misconduct and resulting in a three week chiefly suspension (Milton 1991). However, as Crowder (1977) alleges, a degree of genuine sympathy in individual cases did resonate in his private journal entries.

Overall, the impact of colonialism on Botswana's ethnic identity has been one that further consolidated existing hierarchies in society. Unlike other parts of Africa, colonialism in Botswana did not create new identity groups. However, colonialism in 
Botswana did establish BaTswana as the dominant group at the expense of minority groups. However, it would be the postcolonial elites who would have the most dramatic impact on ethnic relations and identity management through an assimilationist experiment, rhetorically aimed at mitigating the evils of ethnic diversity and ethnic competition.

\section{Assimilation and Identity Management in Post-Colonial Botswana Conceptual Framework of Assimilation}

The traditional assumption of ethnicity is that human beings belong to natural groups which share common language, culture and sense of homeland. These groups have come to be understood as ethnic groups, and although not in and of themselves political entities, many believe that they are the ideal basis for political organization. In nineteenth century Europe, that natural group was referred to as "nation" and came to be regarded as the model of the modern state (Ottaway, 1999: 300). Ethnicity, although in itself an innocent phenomenon, can and has been used as a form of bonding to achieve certain societal and political goals. It has been discovered to be a powerful source of group cohesion that can drive forces and direct its energies and powers into either a positive or a negative course.

As Ottaway (1999) argues, at independence a significant number of African leaders began to reject the legitimacy of ethnic identities, even while relying upon them to bolster their power. This is because the existence of tribalism in Africa became one of the continent's greatest stereotypes and especially European countries viewed African ethnic relations as primitive, rather than accepting them as part of the same phenomena 
as nationalism, which existed in their own countries. The new African elite differed from the traditional elite in that they were usually foreign educated in Western countries and thus were quicker to reject the notion of ethnic difference, albeit not because of its link to conflict but because it was European practice and desire to do so.

Botswana had also learnt from its neighbors the evils of racialization and tribalism. As a result, in 1966 the Khama administration embarked on a series of policy interventions that would reduce cleavages in society in order to build a unified society: a modernist assimilationist policy of social development. Cultural assimilation is defined as the process whereby a minority group gradually adapts to the customs and attitudes of the prevailing culture and customs. In the case of Botswana, the desire was to create a homogenous but political state through a series of assimilation policies highly skewed towards the favor of the culture and language of the eight Tswana identity groups.

\section{Features of Assimilation in Botswana}

The primary feature of Botswana's assimilation policies is what historian Neil Parsons has referred to as the promotion of "Tswanadom". Parsons argues that the concept of Tswanadom as both philosophical and territorial is what has led many to this day to believe that post-colonial Botswana was a mono-ethnic state, a gross misrepresentation. The declaration of Setswana as the national language, as well as the promotion of Tswana culture in all social, political and cultural realms of Botswana, have been pivotal to the consolidation of Tswanadom. To this day education, the media and 
activities in all social domains in Botswana such as the kgotla (chapter 4) can only be conducted in English and Setswana.

Central to the Botswana assimilation policy is the issue of chieftaincy recognition. Botswana's House of Chiefs (Ntlo ya Dikgosi) is part of the legislative branch of government. Although mainly symbolic, it is highly revered as chiefs are deemed the custodians of culture. The House of Chiefs currently has thirty five members. Eight are hereditary and referred to as paramount chiefs, with each paramount chief presiding over one of the eight Setswana speaking tribes. The Chieftaincy Act of 1966 defines "tribe" to mean "the BaNgwato Tribe, the BaTawana tribe, the BaKgatla tribe, the BaKwena tribe, the BaNgwaketse tribe, the BaLete tribe, the BaRolong tribe and the BaTlokwa tribe". All other ethnic groups and sub-ethnic groups are assumed to have been absorbed into these 8 principal identity groupings. The Tribal Territories Acts 1966 reifies this by defining tribal territory only with respect to the Tswana ethnic group and land can only be distributed under the jurisdiction of the territories of these groups.

Another twenty two members of the House of Chiefs are indirectly elected and serve five-year terms. Of these, four are chosen from sub-chiefs in the districts of NorthEast, Chobe, Ghanzi, and Kgalagadi, the remaining five members being appointed by the president. They must be at least 21 years of age, adept at English and have not participated in active politics in the past five years.

Botswana is divided into 8 regions: Kgalagadi, Ghanzi, Kweneng, Central, Ngwaketse, Kgatleng, Ngamiland (Northwest), and South-East Districts. In those districts in which Tswana speaking groups dominated, the name of the district is directly 
derivative of the principle tribe. For instance, Kgatleng District Council has its capital in Mochudi village where the BaKgatla tribe resides and the respective land governing body is the Kgatleng Landboard. The others include the Ngwato Landboard, Tawana Landboard, Ngwaketse Landboard and Kweneng Land Board. The BaLete and BaTlokwa tribe reside in the South-East District, which is given a geographic rather than tribal name designation. The designation of groups rights in Botswana is not sensitive to numerical measures or first-come first served. Instead, the only thing that matters is the primacy of the spoken language. Those tribes in the Northwest (Ngamiland), including the BaHambukushu, OvaHerero, BaSubia, WaYeyi, BaCiriku and BaSarwa, are represented by the BaTawana and are officially regarded and referred to as such. Tribes, whose first language is not Setswana are not represented by their hereditary chiefs.

While the Botswana government's official position is that assimilation helps foster peaceful coexistence, Reteng, a minority lobby group, views the sets of policies as tools for marginalization and disenfranchisement. Reteng is a multi-cultural coalition of organizations devoted to the promotion and preservation of the linguistic and cultural diversity of Botswana's heritage, and as a body, is one of the most critical platforms to Botswana's assimilation policy. Reteng argues that since becoming a republic in 1966 Botswana laws have permitted discrimination based on ethnicity, language and culture. Making reference to Sections 77 to 79 of the Botswana constitution, Sections 15 (4)m (d), 15 (9) of the constitution; Section 2 of the Chieftainship Act and c) the Tribal Territories Act., one finds the following rights being denied to non-Tswana groups:

a) The right to recognition as a tribe with a distinct language and culture 
b) Group rights to land

c) Representation in the House of Chiefs (Ntlo ya Dikgosi)

d) The right to educate their children in their languages

e) The right to educate their children about their histories, customs, values and culture

f) The right to access information and enjoy their languages and cultures on national radio and television

g) Access to certain jobs especially those pertaining to management of land such as Land Board Secretaries.

In 2005, a constitutional amendment failed to address the issue of discrimination of non-Tswana groups from permanent membership to the House of Chiefs. The three unequal categories of membership remained. No efforts have been made legislation that contains derogations which permit non-prohibition of discrimination and give group rights to land to the Tswana tribes as sovereigns of the districts respectively. As a result, in contemporary Botswana, all non-Tswana children are taught in and about Setswana cultures at the expense of their own, and as a result they develop low self-esteem and under achieve in schools (Reteng 2008). The 8 Tswana tribes numerically account for 18percent of the population, while the non-Tswana make up 60percent. This the policies of forced assimilation if not curbed will see the disappearance of over 60percent of the nation's cultures.

To date Botswana's executives have all expressed reluctance to concede to minority group pressures to change assimilationist practices in Botswana. First president 
Seretse Khama campaigned that he stood for the gradual evolution of a nation state in which tribal groups while in existence, would take a secondary place to national identity. Khama stated:

"When I say the greatest enemy of independent Africa is trbalism ....it becomes dangerous when it leads people to think in exclusively tribal terms. It becomes a threat to the stability and security if our state when it is carried out to the point when a man in a responsible position thinks of himself as a tribesman before he thinks of himself as a Motswana”

(Khama quoted in Nyati-Ramahobo 1991:201).

Similarly, his successor President Quett Masire reiterated the orientation towards Setswana to the exclusion of other languages by warning Botswana citizens to stop fighting for the right to have ethnic languages being taught in school as this would break up the nation. President Festus Mogae when asked to mediate a dispute between the BaNgwato and the BaKalanga he urged the BaKalanga to consider themselves BaNgwato. President Ian Khama in 1999 reified this statement to the BaKalanga in Nkange, thus justifying Ngwato hegemony over tribes like the BaSarwa, BaKalanga, BaBirwa, BaTswapong and others considered as minority groups. Furthermore, on March 25th, 2000, Ian Khama stressed to Etsha, an area dominated by marginalized groups such as Hambukushu, Wayeyi and BaSarwa, and informed them that for as long as they are members of the ruling party, they should not support organizations that are formed along tribal lines as they are tribalistic and divisive (Radio Botswana News Bulletin, March 25 th, 2000). This was an attempt to highlight political over ethnic loyalty. He was aware 
that his audience was ignorant of his loyalty to his own ethnic group ( He is a supporter of the Serowe Development Trust, an NGO that belongs to and is run by the BaNgwato tribe). At the policy level, there exists an illusion of achievement of the actualization of Tswanadom through the assimilationist model. The Tswana have groups rights to land, use of language and the privilege to live their culture. The success of Tswanadom has led many to believe that Botswana is a mono-ethnic state. (Parsons, 1985:27)

\section{Impact of Assimilation in Botswana}

One major impact of the assimilation policy in Botswana surrounds the institutions of property rights particularly within the context of land and resource rights. The 1968 Tribal Land Act (amended in 1993) established specific guidelines on the acquisition, transfer and use of customary land. Additionally, tribal Land Boards were created in 1970 regulate issues pertaining to customary land. Traditionally, such activities were the responsibility of the chief. However here they were performed by an array of 'authorities' with chiefly connections (Poku 2002). However, since only the chiefs of the eight principle Tswana tribes are recognized by the constitution, only through assimilation to one of the 8 Tswana tribes, can a non-Tswana person gain access to land. Only under this provision is there no discrimination to access to land.

In terms of access to diamond revenues, during early negotiations, President Khama's tribe, the BaNgwato, stood to benefit the most from mining revenues. By making such revenues a tribal right, Khama could have heavily skewed the benefits of diamond mining towards his own tribe, BaNgwato, a situation that would have probably 
resulted in national conflict. Understanding this tradeoff, Khama and the BDP decided to address the revenue issue in the BDP election manifesto of 1965, stating that

“...leaving mineral rights vested in tribal authorities and private companies must necessarily result in uneven growth of the country's economy, as well as deprive the Central Government of an important source of revenue for developing the country...It will be the policy of the BDP Government to negotiate with all parties concerning the takeover of the country's mineral rights by the Central Government, and subsequently expand the present mining operations and step up prospecting activities throughout the territory".

Khama's decision to foster greater centralization of mining activity assisted in laying firm the political foundations for Botswana's subsequent development by facilitating the equitable distribution of mineral wealth. In terms of mineral wealth distribution, his careful political maneuvering and ability to balance different interest group pressures helped Botswana develop economically, a legacy that has been maintained over thirty years after his death. Khama's most important contribution was to coordinate the interests of Botswana's eight major tribes. Immediately following independence, he made the critical decision that diamond revenues be placed in a national saving fund, as opposed to being allocated to individual tribes. As a result, diamond revenue would be evenly spread out throughout the state in the form of investment, instead of exclusively privileging specific regions of identity groups. Although in the short term, this decision was not popular among the BaNgwato, Khama's tribe, the 
sustained result of Khama's national savings plan achieved greater legitimacy and resulted in minimal tribal conflict.

Professor Balefi Tsie, who identified himself as MoTswana, argues that as a result of assimilation Botswana, although not an ethnically homogenous society, extends citizenship and citizenship benefits to everybody equally.

"Seretse Khama left a legacy where in the employment of civil servants, only merit counts". - Professor B. Tsie

He emphatically states there is no ethnic discrimination, but acknowledges that there are groups such as the BaSarwa, and BaKgalagadi who have legitimate concerns and little representation in parliament. He argues that minorities are catered for materially. There exists very little evidence to the contrary, except when considering BaSarwa and BaKgadlagadi. The only marginalization mentioned in the interviews was that of cultural marginalization, not material marginalization. Professor Mokhawa argues that in addition to having food, and water, a person needs their culture. Cultural autonomy and artifacts have not been given to minorities in Botswana them as much as the dominant Tswana. Both professors view the language introduction exercises from a pragmatic viewpoint, arguing that the introduction of new languages in schools is a very expensive endeavor. Tsie emphasized that minorities have organizations like SPIL and are also awarded airtime after midnight on broadcast media. However, Mokhawa views the minorities pursuit for autonomy as "democracy being tested" as the national Tswana culture is being challenged via the expression of people's tribal identities. 
When asked about the receptiveness to assimilation in Botswana, Dr Zibani Maundeni argued that he believes the policy had a cohesive factor in Botswana. Dr Maundeni, a professor of Political Science at University of Botswana, identifies himself primarily as MoKalanga.

"I come from the north, now according to the people; everybody who comes from the north is a MoNgwato. ”- Professor Z. Maundeni

Being of the optimistic persuasion, he argues that Tswana language and culture have been "accepted" by larger groups and not necessarily repressed. When asked about his view of the imperialist assimilation project in Botswana, he argues that the as a minority himself, he welcomes it as it allows him to "belong" to a larger group. He claims than many are accepting of this greater Tswana identity and Tswana ideology. He goes on to say that people adherence to a greater identity or a greater ideology actually fosters democracy and unity. He argues that Botswana identity groups have an inclusive orientation.

“They don't undermine other people. I am Kalanga for instance. They don't try to discriminate me because I am a Kalanga. Instead they try to incorporate me into that larger group. And that way they make you feel at home. They don't look at the small groups which are usually marginalized; they look at the larger group. That way they are able to relate with you on a positive note. Of course many of us face the problem of denying that we do not belong to that particular group. They have some kind of an imperialist ideology of assuming that all small groups should identify with a larger group.” - Professor Z. Maundeni 
He goes on to add: "You cannot go to war because you are being included in some large group. You go to war because you feel excluded."

The only caveat however, was that minorities had to subordinate themselves into one of the principal Tswana tribes in order to access this mineral wealth. This came at the expense of the right to cultural expression of minority groups in Botswana as the process of ethnic assimilation in Botswana has been the sacrifice of cultural heritage and custom of marginalized groups in Botswana, sometimes brutally. Lydia Nyati-Saleshando (also cited in this dissertation by her former name Lydia Nyati-Ramahobo) is more critical of the ethnic configurations of Botswana and identifies herself as MoYeyi, a member of the Wayeyi ethnic group. She criticizes the assimilationist model and the promotion of Setswana and English languages. She argues that prior to independence languages like SeKalanga were being taught, but after 1966 the pursuit of a cohesive Tswana national identity led to the banning of this language and all other minority languages from classroom instruction. She argues that although the people generally accepted the assimilationist model, they were unaware of its ramifications. The minority ethnic groups were accepting of the British model initially as a way to ensure safety and security. If you are in the Ngwaketse district, they were under the safety of the BaNgweketse.

Saleshando argues that as a result of assimilation, the villages where the nonTswana people live are the least developed for example BaKgalagadi and BaSarwa. She recalled a 2003 proposal for a university to be built in the Kgalagadi region, but the president decided to move it to his own area. 
"If they want to bring people out of poverty they should be giving them access to those things that help them to develop". - Professor L. Nyati-Saleshando

Overwhelmingly, the eight Tswana tribes centered around eight large villages' urban centers where development is concentrated with access to identification services and healthcare, whereas minority ethnic groups have access only to poor roads and unmanaged clinics. The 8 tribes belong to 8 big villages where development is centered. Marginalized minority groups are the most vulnerable and in their areas poverty is rampant and distant from basic social services.

She acknowledges that fortunately minorities in Botswana have not escalated towards violence that other minorities in other African countries have.

Politically, Saleshando argues that ethnic origin is not usually an issue.

"We are used to people coming from one region and representing another region. But certain political parties have rooted themselves in certain regions. Like the ruling party, even if it is losing traction in the northern parts of the country, in Serowe, it's still very strong. The BNF has been strong in Kanye. Other parties Ngamiland and Chobe districts they voted for BCP. It's dependent on the strength of the organizers in the region." - Professor L. Nyati-Saleshando

One point of contention for Saleshando was the lack of representation in the House of Chiefs of the hereditary chiefs of minority ethnic groups and tribes.

"For minorities, even if you designate your chief like the Wayeyi have, they are not recognized in the house of chiefs because the constitution of Botswana does not 
recognize the Wayeyi as a tribe. In the region, a headman attends the House of chiefs to represent the minority groups, but they come under the paramount chiefdom that rules the region. The head man is not elected by the people and represents nobody. They report to the paramount chief". - Professor L. Nyati-Saleshando

Nyati-Ramahobo argues that BaKalanga were systematically harassed by BaNgwato to speak Setswana. Similarly, the Wayeyi were severely punished for speaking Shiyeyi resulting in it now being one of the world's endangered languages (Reteng, 2005) Assimilation has had a cultural impact too, whereas BaTswana are culturally patrilineal, Wayeyi are matrilineal in inheritance. They have now abandoned their heritage and adopted the patrilineal patterns of ownership and inheritance observed under Tswana custom, and marry according to Tswana customary norms. There are however features of cultural amalgamation as is evidenced by the birth rites in the North West district which combine both Tswana and Wayeyi culture.

Group grievances by minority groups get very little attention in Botswana. A petition by the Kamanakao Association, non-governmental organization with the basic objective of maintaining and developing the remnants of the language and culture of the Wayeyi people of northern Botswana, was rejected in May 2000. Proponents of structural assimilation believe that group rights restrict individual rights to some extent, and they regard assimilation and amalgamation as anti-pluralist. In Botswana group rights are tolerated through registered organizations. However, such organizations such as the Society for the Promotion of Ikalanga Language (SPIL) and the Kamanakao Association, which are working on the development and promotion of the Ikalanga and Shiyeyi 
languages respectively, have met Government resistance, with some Government officials labeling them as tribalistic (Radio Botswana News Bulletin, 2000). This indicated intolerance of minority group demands.

Opposition member Gobotswang characterizes the plight of minorities in Botswana as the "brutal suppression of the expression of culture" and "suppression of dissent. He employs the term "brutal" in the sense of the brainwashing and installation of the belief that speaking Setswana would bring one united national government propagated that in people's minds. He critiques the Botswana assimilationist project in comparison to South Africa. There, citizens have a basic understanding of each other's language but tend to co-exist peacefully, while expressing their cultural heritages. $\mathrm{He}$, however, praises the Botswana government for not allocating resources according to ethnicity, thus resulting in very little agitation where resources allocation is concerned. The only agitation emerges from the desire to express culture and langue freely, and for that he says Botswana still has a long way to go. He argues that "cultural groups are not political in nature they just want their languages to be taught".

The assimilationist policy in Botswana has managed to limit the evils associated with ethnic diversity by creating an inclusive ethnic identity and promoting it as Tswanadom. Having observed the negative impact in of "othering" and tribalism in apartheid South Africa, and other African counterparts, the Botswana elite decided to approach the issue from a pragmatic viewpoint, constructing an inclusive identity that would become prior to individual tribal identities. This national identity, branded 
Tswanadom, would mitigate the ills of ethnic diversity by creating a sense of togetherness that does not exist anywhere else on the continent.

\section{ANALYSIS AND CONCLUSION}

Botswana's assimilation policy was extended to nearly all identity groups in the county. The Botswana government pursued the principles of non-racialization, tolerance as well as equal opportunity reflective of their pre-colonial assimilationist tendencies to incorporate smaller groups into the larger Tswana merafe. BaTswana were overwhelmingly tolerant of a Caucasian first lady, showing that their tolerance went beyond tribal and ethnic differences, but also transcended racial and religious lines as well, with Gaborone hosting one of southern Africa (a predominantly Christian region)'s largest mosques.

The case of Botswana clearly demonstrates that different ethnically diverse societies have varying degrees of conflict potential. Ethnic conflict potential emanates either from a history of violent relations among identity groups within a state, the existence of historical grievances, or the creation of new grievances. The Botswana government upon independence acknowledged this and instead of allowing ethnicity to be an impediment to economic and social development, put in place a meticulous set of policies aimed at transforming identity politics in the country. The Botswana government thus institutionalized an identity fashioned to parallel to the European concept of nationhood that would be prior to any other identity based on ethnicity, culture or language. In a bid 
to reduce ethnic distance among the various identity groups in the country, the government institutionalized the Setswana language in education and media and adopted Tswana customs and traditions of conflict resolution such as the kgotla.

The Botswana case reflects an institutional approach to fostering an artificial ethnic unity. States are capable of channeling identity politics into peaceful political competition provided credible commitments are made to shape and uphold agreements made among culturally defined political actors. However, when the state's administrative structures and legal institutions distribute resources on the basis of ethnicity, it encourages political mobilization and conflict along ethnic lines. Botswana's assimilation policies thus placed constraints on societal behavior and provided incentives for cooperation and compliance of rules and procedures for allocation, participation, representation and accountability. Cheeseman and Ford (2007) argues that Botswana has been at least "partially representative" in its politics with substantial political representation of both women and minority populations. Those who were willing to assimilate to larger ethno-linguistic clusters of Tswanadom benefitted more than those who rejected assimilation, such as the BaSarwa. The BaSarwa debate in Botswana is contextualized in the debate of development versus cultural preservation. There exists tension between the Government of Botswana which claims to want to get the BaSarwa out of a "primitive" lifestyle into a modern lifestyle through assimilation, and activists such as Survival International who advocate for the preservation of BaSarwa cultural and heritage rights by advocating nonassimilation. Unfortunately, voluntary non-assimilation on the BaSarwa's part has left them outside of the Botswana miracle. 
A common recurring theme I noticed while in Botswana is that most Botswana citizens of all ethnic backgrounds are proud of their country and their political identity as a people of the same republic. They are gratified with the economic progress and the general international acclaim that their country has achieved globally. The only grievance held by most minorities however, was the failure of the government to acknowledge that it is not only access to economic and political resources that make an identity group content and instead, these resources also encompass cultural and language resources, which for the most part the Botswana government has taken away from the minority ethnic groups, particularly the BaSarwa, through forced assimilation. However, when measuring Botswana's potential for ethnic conflict over resources or institutional failure due to ethnicity, this dissertation found very little evidence of that. According to NyatiRamahobo (1991), since independence the government of Botswana has worked tirelessly to achieve the ideal goal of a homogenous nation-state in which ethnic identities would lose significance. Assimilation has been pursued in the designation of landboards and respective land rights along Tswana tribal lines. Access of minorities to land is only through their allegiance to one of the eight constitutionally recognized tribes. An example is BaTawana who are a numerical minority in their district, but have control of the land. All residents of their district, including the Wayeyi are officially referred to as MoTawana tribesman, a political rather than cultural naming. Minorities like the Wayeyi who are an ethnic minority in the North west district are both politically and culturally defined as a MoTawana, as he or she is expected to sing to a MoTawana Chiefs in Tswana and not in Shiyeyi. 
The Botswana government implemented the assimilation policy in a bid to reduce the ethnic distance between the various identity groups. Caselli and Coleman (2011) argued that ethnic cleavages that are only marked by a shared sense of identity or history, yet not convoluted by observable differences such as color, religion or language, are normally associated with a low level of ethnic distance. This perhaps illuminates why Botswana may have not experienced ethnic conflict, based on diamonds or anything else. First, as Lawrence argues, Tswana kingdoms were historically not crusader states and identity groups in the country coexisted peacefully for centuries prior to colonialism.

Furthermore, they shared a lot of common histories, a sense of homeland, culture, and customs. Second, the assimilation policy implemented by the Botswana Government institutionally "reduced" the ethnic distance among Botswana's identity groups giving them a common language, albeit compulsorily, and institutionalizing the Setswana language in all social domains. The government privileged the culture of eight tribes whose first language was Setswana, ordaining their hereditary chiefs as paramount and making all other identity groups subservient to these eight chiefdoms. Today, nearly all Botswana citizens with the exception of the BaSarwa ethnic group and the expatriate communities speak Setswana as either a first or a second language. Third, Botswana's cultural assimilation was facilitated by some primordial similarities among ethnic and tribal groups in the country. As mentioned earlier in this chapter, totemism provided an added layer to identity in Botswana The fact that totemism provided a legitimate cohesive element to tribal relations may have facilitated the voluntary ascription of minority ethnic and tribal groups in Botswana. Totemism provided the basis of common ancestry, blurring the lines of ethnic difference, thus reducing ethnic distance among the Botswana 
population. Fourth, Botswana's history is absent of what the factors cited by Blagojevic (2009) such as structural crises, historical recollections of inter-ethnic grievances, institutional factors promoting ethnic prejudice, and manipulation of historical memories by political entrepreneurs to evoke sentiments such as fear, resentment and hate toward the "other" as well as an inter-ethnic competition over resources and rights. Instead, the goal of assimilation in Botswana was to circumvent these factors.

The positive effect of assimilation in Botswana was the fostering of a national identity, albeit artificial, as suggested by the concept of "Tswanadom". The phenomenon of Tswanadom has created a social cohesion in Botswana not found in most other countries in sub-Saharan Africa and has thus been critical to nation-building. In its rhetoric, the government continues to justify the promotion of Tswanadom as a cultivator of nationhood and unity. This national unity is seen to have limited the threats and perils associated with ethnic heterogeneity, albeit at the cost of minority cultural rights in Botswana. It did provide for institutional quality. However, ethnic homogeneity is not a primordial truth in Botswana, but a socially constructed phenomenon and therefore does not completely reflect the assumption of this chapter's hypothesis fully. 


\section{CHAPTER SIX}

\section{THE EXOGENOUS SOURCES OF INSTITUTIONAL QUALITY IN}

\section{BOTSWANA}

\section{Exogenous Sources of Institutional Quality: An Introduction}

External agents have played a role in facilitating and/or disrupting political, social, and economic institutions in Africa. These influences originate from both state actors and non-state actors. With the adoption of the liberal type of economic development, non-state actors, particularly multinational corporations investing in Africa, have shaped the institutional setting affecting economic and political development. This dissertation examines the role that external factors played in shaping and influencing institutional development in Botswana. In particular, it isolates three relationships which bore the most influence on Botswana: its relationship with its colonial master Britain, its relationship with regional hegemon South Africa, and its relationship and dependence on the most powerful non-actor in its economy, De Beers. The conceptual framework of the dynamics of these relationships will be the focus of this section. Later, a comprehensive analysis of how these relationships manifested in the Botswana case will be done. 


\section{Asymmetric State Relations: Colonialism}

The key external legacy that steered the formation and shaping of modern states and institutions was that of colonialism. It is cited as the main source of the relative weakness of African states, in the aftermath of centuries of transcontinental slave trade. Variants of colonialism shaped the continent, with the French pursing colonial policies of assimilation where subjugation and civilization of the "heathen" was the primary foundation for structural integration and dependence in its colonies. Most African countries' institutional development and institutional choice have been shaped and influenced by an asymmetric relationship with an external actor, whether through of colonialism, or through the actions or diplomacy of international or regional hegemons. Of interest to this dissertation, particularly, is the asymmetric relationship between Britain and Botswana, as well as that between South Africa and Botswana. In Chapter 3, an in-depth analysis was made to discuss the role colonialism played/or failed to play in Botswana. However, as this chapter will illustrate, Botswana's colonial past is best understood in comparative perspective to the colonial experiences of other countries' experiences.

La Porta (1998) and Acemoglu \& Robinson (2003) identified various factors that determine the extent of the colonizer's influence. First they argue that the colonizer's identity had an impact on the development path of the ex-colonies through the nature of the legal system imported in the colonies. Thus, former French colonies and former British colonies exhibit differences in the way their institutions were shaped. According to Lee and Schultz (2011), generally former British colonies fared better in terms of 
growth and poverty alleviation after independence than former French colonies. Second, the European settlement played a huge role in infrastructural development. Acemoglu, Johnson, and Robinson (2000), show that the type of colonialism had a profound impact on the contemporary development of former colonies, through the quality of the institutions. They distinguish between extraction and settlement colonialism, and argue that the more Europeans settled in a colony, the better the quality of the institutions became, and the more the colony developed. This is because settlers had a long-term vision of living on the land and therefore established functional institutions aimed at long-term development. This distinction greatly explains the disparity in development between South Africa and the rest of the continent. Third, the administrative organization i.e., whether the type of colonialism was direct or indirect, influenced development outcomes in post-colonial Africa. Banerjee \& Iyer (2002) studied the impact of the type colonial rule (indirect rule versus direct rule) on the development of Indian districts and provided evidence that the districts that were under the direct rule, that is to say directly administrated by the British themselves, now have better economic performances than the districts that were indirectly administrated through Indian landlords' intermediaries. In the case of Botswana, the choice of formal political institutions was greatly influenced by the British as at independence. The country adopted the British Westminster model of government and operates as a parliamentary republic.

Asymmetrical state relations, particularly those colonial in nature were the focal point of Atul Kohli's analysis on state directed development. Kohli (2004) argues that the ability of states to create developmental capacity to a great extent results from 
exogenous factors which shaped the process of state construction. Thus, he distinguishes between three archetypes of states in the global periphery, each a product of colonialism. These archetypes are the cohesive-capitalist state, the fragmented multiclass state, and the neopatrimonial state. The cohesive capitalist state and the neopatrimonial state according to Kohli (2004), exist at the two extremes of the political effectiveness continuum, with the cohesive-capitalist states being the most developmental.

Kohli (2004) cites South Korea as one key example of a cohesive capitalist state. He determines that state construction emerged from Japanese colonial rule which differed in many important respects from the colonialism of the European powers. The Japanese were late developers and enjoyed the geographic proximity to their colonies, unlike their European counterparts. This enabled Japan to make extensive use of state power for its own economic development, and then use the same state power to pry open and transform Korea within a relatively short period of time. The Japanese colonial impact was intense, brutal, and deeply architectonic, eventually leading to the origination of South Korea's cohesive-capitalist, growth-promoting state. The colonial period in Korea realized a relatively corrupt and ineffective agrarian bureaucracy being transformed into a highly dictatorial and penetrating political organization. In addition, the state established close and working production-oriented alliances with the dominant classes; and a welldeveloped system of state control of the lower classes was created (Kohli, 2004:18). Eventually, these structures were battered by numerous new forces eventually providing South Korea with a framework for the evolution of a high-growth political economy. 
Before the advent of the Japanese colonial system, Korea had an agrarian past, and a centralized and ostensibly strong bureaucracy, but was a relatively weak state. Much of the institutionalism in Korea was guided by antiquated traditions, and officials were inept at the successful application of finance and administration, which would have allowed them to transition easily into the modern systems of formal education, financial systems, and advanced military. The Japanese thus implemented a modern and efficient bureaucracy albeit inherently more "Japanese" than "Korean." The Japanese model of colonialism thus substituted the factionalized and conflict-prone institutions of aristocracy with a modern, highly centralized, and extremely capable state apparatus, one which was used to reshape Korean society. However, the Japanese did this strategically in order to maximize the quality, effectiveness, and usefulness of their colonies in Korea thus reshaping Korea's political economy to match their own experiences. As a result, the 36-year occupation of Korea by Japan had a tremendous influence on the development of the modern Korean management system.

In contrast to the Korean colonial experience, British colonialism in Nigeria created a highly distorted state that readily evolved into a neopatrimonial and ineffective set of political organizations. Britain ruled Nigeria on a tight budget and expended little energy in maintaining this colony. British colonialism in Nigeria followed an ideology of indirect rule in which the British essentially utilized various "traditional" rulers to impose order. In Nigeria, colonialism gave political significance to identity divisions in the country. The country had already been diverse prior to colonization, but the instigation of indirect rule consolidated the ethno-linguistic, geographic and religious fault line in 
Nigeria. In 1914 it was the British who brought together the north and south, and coined the name "Nigeria," giving common governance to an area previously governed by diverse traditional authorities. This division worked to the benefit of the British partly to remove the threat of a unified opposition nationalist movement. Hence a divided state was safer for the minority British administrators than would be the unified one that existed after independence. The British actively prevented interaction between northerners and southerners, both culturally and economically. For example, they constructed no transportation network between the north and the south. This is in sharp contrast to the cultural unity present in Korea. The cultural divide of Nigeria worked well for administering a colony, but was detrimental in preparing a state for independence. In the north, the British implemented indirect rule relying on strong Islamic leaders to govern in their interests. In the south, they imposed direct British rule. In the north the British had less impact on customs and culture, while in the south it pursued more westernization in education and culture (Middleton, 1997).

At its core, colonialism in Nigeria reinforced a form of patrimonial and personalistic rule that failed to centralize authority and to develop an effective bureaucracy and civil service. It also failed to develop even such minimal political capacities as the ability to collect direct taxes. After the Second World War, the colonial state's access to resources grew and the state became more and more involved in the economy. The distorted beginnings of the state were further accentuated, as the state became further enmeshed in particularistic and personalistic networks. The political elite of sovereign Nigeria were never able to overcome the original deficiencies of state 
construction through colonialism. As a result, post-independent Nigeria has been characterized by crisis after crisis, both controlling and wasting the society's scarce developmental resources.

As mentioned already in the previous chapters, British colonialism in Bechuanaland varied between what Acemoglu (2001) describes as "light rule" and what Beaulier (2003) characterizes as "benign neglect". This was the archetypal "indirect rule" that Nigeria experienced in the north. British interest in Botswana was limited, except in its strategic importance as a pathway to the continent's interior from the south and as a way to prevent occupation of the territory by foreign powers particularly the Boers in the South and the Germans in the west. The characteristic of Britain's occupation in Botswana is best characterized by Seidler (2011) as "miniscule," with little interaction between the British and the colonial population; as imposing of forms of taxation; as permissive of the preservation of chiefly institutional powers and autonomy over judicial, legislative and executive functions; and as one that did not invest in much infrastructure, with 75 percent of British colonial spending being used for administrative purposes alone. As a result, the British did not engage in any form of nation-building in colonial Bechuanaland. The contrasting fortunes of Botswana and Nigeria's experiences with indirect rule calls into question the impact of colonialism on explaining institutional quality in Botswana. The main impact of the colonial enterprise that drastically changed Tswana institutions is that of taxation, which introduced a cash-based economy replacing the pre-colonial barter trade system. Taxation enhanced the clout of Tswana chiefs who received a 10 percent commission of what they amassed (Good 1999: 188). Moreover, it 
generated a demand for cash based income among BaTswana, and resultantly facilitated for a mass departure to work in South African mines. Britain, although not active in the provision of public goods in post-independence Botswana, did meaningfully change the political and legal institutional setting of colonial Bechuanaland. Botswana adopted a Westminster style parliamentary system and a British common law legal code. To that extent, British played an essential role in influencing Botswana's institutions, an analysis of which already been covered in chapter 3 . However, whether as this dissertation argues, it was not the choice of institution that mattered as much as the setting into which the institution was inserted, and whether the choice of British institutions was the key reason for success of Botswana does not necessarily follow the adoption of British institutions. Had an alternative institutional framework been implemented in Botswana, the country may have still obtained its level of institutional quality.

\section{South Africa and Botswana}

\section{Regional Hegemony's Impact on Institutional Development}

Even prior to becoming a republic, South Africa has been Botswana's primary economic, diplomatic, political and socio-cultural partner. Botswana's relations with South Africa are more important than its relationship with any other country due to the intricate relationship that emerged prior to colonialism. Today, there are nearly three times as many Tswana speaking people in South Africa than in Botswana, and both are original members of the oldest customs union in the world SACU, established in 1910. 
South Africa boasts regional hegemony in southern Africa, being the largest economy. Regional hegemony has generally been regarded as the outflow of superior material and/or military influence regionally, connoting a political order where a powerful state dominates a region (Prys, 2007:7). This section will delve into the relations between Botswana and South Africa, and how this relationship has shaped institutional development in Botswana.

According to Prys (2008) the projection of the hegemon's values and interests is a defining feature of regional hegemony. Secondary states following a regional hegemon are generally socialized into accepting the values and rules of the hegemon as the "right thing to do". This acceptance of values may be translated into the choice of certain formal institutions which reflect the interests of the regional hegemon. Specific activities of the hegemon promote its own vision and values for the region, such as establishment of institutions and agenda-setting within those institutions, mediation of conflicts and financial assistance and if relevant, the conditions attached to it, a more immediate form of value projection is the direct construction of a similar political system in the secondary states. Lastly, Prys (2008) argues that regional hegemony is unique from other forms of hierarchical state relations in unilateral provision of public goods. It is with this theoretical backdrop that the selection of South Africa as a possible shaper of Botswana's emerged.

Until 1976, South Africa directly controlled Botswana's monetary policies the Rand Monetary Area. Additionally, Botswana's mineral reserved and manufacturing sectors were greatly impacted by the dependence on South African exports dictated by 
the regional hegemon through the Southern African Customs Union (SACU). Botswana was diplomatically antagonistic towards South Africa's apartheid system and at times was vulnerable to destabilization due to cross-border attacks on ANC forces based in Botswana. This was nevertheless to a considerably lesser degree than other countries in the region, and indirectly contributed to Botswana's achievement of relatively higher growth rates. Botswana chose to maintain a close relationship with apartheid South Africa, pursuing pragmatic economic policies in light of its geopolitical circumstances. This section queries the role of this close relationship in the development of Botswana's institutions through a historical analysis.

\section{Pre-1966 Botswana - South Africa Relations}

Botswana's territorial integrity and identity has been under constant threat and its autonomy continuously challenged due to the hegemonic aspirations of its powerful southern neighbor South Africa. As mentioned in Chapter 3, prior to the formation of the Union of South Africa (present day South Africa's predecessor) in 1908-1909, Bechuanaland had been divided into two unequal portions: British Bechuanaland and the Bechuanaland Protectorate, respectively south and north of the Molopo River. British Bechuanaland was part of the Cape Province of South Africa, which was the linchpin between the two Rhodesia's (now Zimbabwe and Zambia) and German South West Africa (now Namibia). British Bechuanaland served as the administrative headquarters and railway corridor for the Bechuanaland Protectorate, which became Botswana at independence in 1966. Bechuanaland's first capital was located in Vryburg, Cape 
Province, until 1895, when it was moved north along the railroad to Mafikeng (then called Mafeking), another small town in the Cape. The Bechuanaland Protectorate's administrative headquarters remained in South Africa in an area of Mafikeng known as the Imperial Reserve. The protectorate's capital was finally relocated outside South Africa for the first time to Gaborone in 1965. From 1897, when the railway line was opened from Vryburg to Bulawayo in neighboring Zimbabwe, until September 1974, when the line was completed from Rutenga to Bainbridge, no movement could occur between South Africa and Zimbabwe without a Botswana transit.

The Bechuanaland Protectorate was administered directly through the British government as one of three High Commission territories: Basutoland, Swaziland and Bechuanaland. Each territory was governed by a resident commissioner who ruled according to decrees issued by the High Commissioner for Southern formulated in close consultation with the resident commissioners. Each territory had two advisory councils to represent the interests of Africans and European populations, respectively. A High Court of the High Commission Territories served as court of appeal in civil, criminal and administrative law and a system of tribal courts operated alongside the territorial courts. Law enforcement was under the charge of Bechuanaland Border Police, Bechuanaland Protectorate Police, Swaziland Protectorate Police and Basutoland Territory Police respectively. Economically, the main activities of the territories were subsistence farming and livestock rearing, with the majority of households subsisting on agriculture or migrant labor, primarily miners who remained in South Africa for 3 to 9 months. The Territories formed part of the Southern African Customs Union (SACU). 
A major turning point in the history of all three territories came in 1910, as the British colonies in South Africa moved toward a political union with the former Afrikaner republics. The move manifested in the unification of Cape Colony, Orange Colony, Natal Colony and Transvaal Colony. From the inauguration of the Union of South Africa ${ }^{34}$ in 1910 until 1961, when South Africa became a republic, Bechuanaland Protectorate was under constant threat of incorporation into the union, and during that time period, its existence as an autonomous entity was heavily contingent upon the state of Anglo-South African relations.

According to Dale (1995) there were aspects of the triangular relationship among the UK the BP and South Africa that bore on the question of Botswana's autonomy. First, with respect to ethnographical considerations, the proposed transfer of Botswana to South Africa would have rejoined groups that had been separated administratively by colonial boundaries. Presently more than twice as many Setswana-speakers reside in South Africa than in Botswana itself ${ }^{35}$. Despite the appeal of kith and kin arguments, white South Africans considered the ethnic arithmetic more than the Tswana of the BP. This was documented in the 1954 Tomlinson Commission Report, an 18 volume report that called for the development of the Union's homeland areas called Bantustans for Africans. The

\footnotetext{
${ }^{34}$ The Union of South Africa is the historic predecessor to the present-day Republic of South Africa. It came into being on 31 May 1910 with the unification of four previously separate British colonies: Cape Colony, Natal Colony, Transvaal Colony and Orange River Colony. Following World War I, the Union of South Africa was granted the administration of the German South-West Africa colony as a League of Nations mandate and it became treated in most respects as if it were another province of the Union.

351.7 million versus roughly 0.75 million. (2010 census estimates total population of South Africa 49,991,300, 10.3\% of South Africans speaks Setswana. This would be 5.2 million Setswana speaking people in South Africa. Total Population of Botswana is 2,024,787 2011 estimate. 78.2\% Speak Setswana, a figure is 1.6 million estimated Setswana speakers in Botswana. This means that $325 \%$ more Setswana speakers in South Africa than in Botswana.
} 
Report embodied the apotheosis of separate development apartheid philosophy, espoused by South African Prime Minister Hendrik F. Verwoerd. The report hinted at the inclusion of the three High Commission Territories (HCT's) within the Union.

The second consideration underlying the incorporation of the Bechuanaland Protectorate into the Union of South Africa was white access to land. Land hunger among poor Afrikaners concerned the British in Southern Rhodesia, who rejected a 1922 proposal by South Africa to join the Union due to hostility and fear of Afrikaner immigration.

The third consideration was the prestige of South Africa. Having been defeated by the British in the 1899-1902 South Africa war, the Afrikaners transferred the contest for primacy in South Africa from the battlefield to the diplomatic fields. The Afrikaners wanted a republic as opposed to a monarchy, in order to reduce British influence over South Africa. The Afrikaners wanted to have autonomy to shape their own domestic and foreign policies including racial, trade and defense links with neighboring colonies.

A fourth aspect to the question of BP transfer to Union of SA involved the question of the self-determination of the people of the BP. Leaders of the eight principal Tswana groups represented on the Native (later African) Advisory Council acquired tenacious British protection against South African incorporation. The Tswana chiefs largely believed that British protection would offer them some security of rule and a defense against Afrikaner land appropriation. 
A fifth consideration was the 1938 Anglo-South African agreement to broaden and deepen the technical, scientific and economic links between the Union and the HCTs with a view to creating a more favorable climate of local opinion with respect to the prospective transfer. To facilitate this enterprise, an allocation of 35000 pounds was made. The BaTswana had their doubts about what they perceived as Pretoria's Trojan horse, which would ultimately lead to incorporation. The two governments established a Joint Advisory Conference on Cooperation, which included the resident commissioners of all three HCT and the South African secretaries of agriculture, finance and native affairs. It filed its first report in May 1938 which because of the Second World War was not published until 1952 when the transfer issue arose again (Dale, 1995).

In 1962 South African Prime Minister Hendrik F. Verwoerd's assertion that the transfer of the three High Commission Territories to South Africa was no longer feasible, ended roughly a half century of diplomatic maneuvering between the UK and "the king of Southern Africa". The conflict had emerged from the wording of the 1909 South Africa Act, which allowed, but did not require, the transfer of the HCT to South Africa with the British government's permission. In terms of Section 151 of that Act, the South African parliament could request a transfer of the HCT from the British monarch which would be guided by the Privy Council's decision in the matter. Consequentially, South Africa's segregation policies and opposition of local chiefs halted the possibility of annexation.

Although many expected Bechuanaland, Basutoland, and Swaziland to become a part of the new Union of South Africa, British high commissioners, William Palmer and 
Lord Selborne resisted such an amalgamation. Though he envisioned an eventual unification of the protectorates with the union, Selborne insisted that such a development could happen only in the long term. This development proved to be a mixed blessing for African leaders. Although it exempted the territories from increasingly repressive legislation implemented by the Union of South Africa, it was also predicated on maintaining "traditional" systems of governance and offered limited scope for popular change. The powerful economy of South Africa further complicated the territories' autonomy, as all three were still heavily reliant upon the remittances from migrant laborers who traveled into South Africa to work, particularly in the mining industry. The colonial tax introduced by the colonial government created the demand for job migration to South Africa to work in mines. As many Tswana males sought employment, job migration to South Africa and the Transvaal became widespread in the Bechuanaland Protectorate. By the year 1943, the majority of the BP's male workforce between 15 and 45 years were working in South Africa (Acemoglu et al. 2001: 14-15 and Schapera 1993: 405).

\section{The South African Customs Union (SACU) and early Botswana/SA relations}

The South African Customs Union (SACU) established in 1910 boasts the distinction of being the world oldest customs union. It came into being as a Customs Union Agreement between the Union of South Africa and the High Commission Territories (HCT's) of Bechuanaland, Basutoland and Swaziland. Generally cited as a manifestation of South Africa's hegemony, the SACU created benefits that have been 
highly skewed towards the benefit of South Africa. According to Alden and Soko (2005) "SACU provides the most conspicuous example of how South Africa has acted as a 'malevolent' hegemonic power" in Southern Africa (Alden and Soko, 2005:370). This section argues that instead of helping Botswana's institutional development, the exercise of South Africa's regional hegemony through SACU actually choked Botswana's efforts to create its own independent and autonomous trade policies and regimes. Botswana's trade institutions were greatly skewed towards catering to the needs of South Africa, and for the most part, participation in the SACU was a negative influence on Botswana's institutions.

It is apparent from the $1910 \mathrm{SACU}$ document that South Africa wielded its power upon the rest of the members of the customs union since its inception. The original agreement, a short document containing 6 articles, outlines the terms of tariff and revenue allocation and bestows upon South Africa the custodianship of the policies. The agreement utilizes South African institutions like the Treasury and the Board of Trade and Industry as responsible for running SACU, with no provision of joint decision making or amendment to the agreement. Preamble 25 stated that the high commission territories should maintain a tariff similar to that which existed in the Union of South Africa.

Article IV of the 1910 Agreement reinforced South Africa's right to determine unilaterally all issues relating to the Custom Union's common external tariff: 
"The Territories shall, as far as possible, conform to the laws and regulations within the Union in respect to refunds, rebates, abatements, suspensions, methylation, prohibitions, removals in bond or otherwise and interpretations of the Tariff".

According to Gibb (2006) this clause effectively removed from the HCTs their power to independently increase public revenue. The 1910 agreement made no mention of the free interchange of products originating in the HCTs. Furthermore, it failed to make any provision for the HCTs to manage their own economies as economic development beyond resource extraction. In Gibb's (2006) opinion, this was mainly because the HCT were expected to join the Union of South Africa eventually and the 1910 agreement was therefore envisioned as only a provisional measure.

When Britain began to delay the incorporation of the HCT, conflicts emerged, illuminating the depth of the unequal relationship between South Africa and Botswana, Lesotho and Swaziland (BLS). First, South Africa's unilateral 1925 decision to implement protectionist policies of import substitution had a profound impact on BLS. Consumers in the BLS were forced to purchase South African goods at internationally uncompetitive rates, resulting in trade diversion and net loss of welfare in the HCTs. Although this was detrimental to the welfare of BLS states, it did not prompt the development of alternative institutions and these countries remained greatly vulnerable to South Africa. This episode clearly illuminated the lack of fiscal discretion and influence of BLS over SACU's industrial and fiscal policies. Second, South Africa's attempts to restrict the export of cattle from the HCTs to the Union during the period 1923-1941 illustrated South Africa disregard for both the economic well-being of the Territories and 
the obligations of the Customs Union. For Bechuanaland, one of the principal benefits of the 1910 Agreement was the enhanced and secure access it provided to the Union market for the export of cattle. In 1923, following several years during which the price of beef fell dramatically, South Africa and the HCTs agreed to establish a minimum weight limit of 800 pounds for cattle exported from the HCTs to the Union. South Africa chose a weight limit, as opposed to quota restrictions, because it would affect less the significant numbers of cattle in Swaziland and Basutoland owned by Afrikaner farmers. The HCTs reluctantly accepted the weight restrictions in the face of threats by the South African Minister of Agriculture. Similarly, the South African government reinforced their protectionist policies by imposing quota restrictions on the export of Swaziland timber in order to safeguard South African pulp mills Gibb (2006). This period reflects the little power Botswana had in developing independent institutions and strategies for trade. The adoption of South African institutions for trade, created a dependency on South Africa from early on in the two countries' history.

During the period 1910-1969 the HCTs were characterized by economic vulnerability and political uncertainty. The territories remained heavily reliant on the Union for revenue and markets, with little to no influence over their own economic destinies. Both South Africa and Britain pursued a deliberate policy of active underdevelopment, albeit for dissimilar political reasons (ibid). The agreement was colonial in origin and reflected South Africa's geostrategic desire to transfer the HCTs to South Africa. Second the agreement peripheralized the HCT and reinforced their subordinate position relative to South Africa. The HCT's tariff policies, industrial were de 
facto transferred to the Union, essentially institutionalizing a transfer of sovereignty to the Union. Third, South Africa established a precedent of altering the agreements by protecting markets and changing the terms of market access. Lastly, the absence of an independent institutional structure designed to govern the Customs Union, maintained a profoundly unequal and asymmetric relationship between the BLS and South Africa.

The inequities of the $1910 \mathrm{SACU}$ agreement and the independence of the HCT in the 1960's led to a renegotiation of the SACU agreement. The new agreement established the Customs Union Commission ${ }^{36}$ composed of representatives of all five members as the primary, but consultative, body of the customs union. By now, SACU had incorporated Namibia. Similar to the 1910 Agreement, South Africa had the power to determine unilaterally SACU customs tariffs, rebates, anti-dumping and countervailing duties, excise and other duties. However the new agreement required South Africa to consult with Botswana, Lesotho, Namibia and Swaziland (BLNS).

SACU tariff policy remained formulated and determined by South African institutions. In practice, Gibb (2006) argues the South African Board of Tariffs and Trade (BTT), an influential quango (quasi nongovernmental organization), funded by the South African Department of Trade and Industry and with no BLNS representation, had authority to make recommendations that were generally accepted. The absence of BLNS power to challenge South Africa, or even influence SACU policy, was illustrated by the creation and operation of the Custom Union's infant industry protection policies. Under Article VI of the Agreement the HCTs were allowed to:

\footnotetext{
${ }^{36}$ However, Gibb 2006 argues that the real power of SACU lay in the ad hoc Liaison Committees.
} 


\section{“...levy additional duties on goods... to enable new industries ... to meet}

competition from other producers or manufacturers in the common customs area".

Although the 1969 Agreement made provision for industries of major importance (ArticleVII) and infant industries (Article VI) any action had to be sanctioned by Pretoria which had the right to deny access to the South African market to those goods afforded protection. Thus, whilst the 1969 SACU Agreement allowed for infant industry protection in order to encourage the development of the less advanced members and to afford all parties equitable benefits from trade, the reality on the ground was more complex. South Africa found itself unwilling to allow the HCTs to protect infant industries that could threaten South African trade.

Only in the post-apartheid era, with the end of white minority rule in South Africa did meaningful negotiations commence on the range of issues? to address in the 1969 agreement. Both the 1910 and 1969 SACU agreements had democratic deficiencies, with BLNS never having the ability to determine their own tariff and excise policies. This represented a serious loss of sovereignty and affected several key policy areas, including industrial, fiscal and development policies. The nature and extent of South Africa's institutional dominance of SACU, although embedded in the region's colonial experience, remained virtually unchanged for 94 years. Since 1889, the white-ruled parts of southern Africa dominated completely the various customs union conventions. After 1990, the customs union was referred to SACU as a 'colonial relic' and Nelson Mandela described the organization as a 'reflection of the colonial oppressor's mentality'. The institution was seen as colonial, undemocratic and, perhaps most importantly, a legacy of South Africa's 
apartheid past. This led to steps by the Mbeki administration to renegotiate the agreement for a third time in 2002.The new SACU agreement signed on October 21, 2002 in Gaborone was far more comprehensive containing 51 articles and encompassed three main sections: institutions and governance, trade liberalization and regulation and revenue sharing.

Early Botswana- South Africa relations can be understood within the context of semi-dependency, derived from the role of the South African mining industry. South Africa benefitted from the relationship through mining and trade profits extracted from Botswana's cheap labor reservoir as well as from a market for South African manufactured products exported to Botswana that posed limited competition.

\section{Apartheid South Africa's Relations with Independent Botswana}

The formation of the Organization of African Unity (OAU) [now African Union (AU)] in 1963 saw the institutionalization of pan-Africanism as well as a regional approach to undermining the regimes of African countries still under white minority rule. One of the main guiding principles of the OAU was its dedication to the eradication of all forms of colonialism, although its main challenges were in white minority led southern African countries. The OAU proposed two ways of ridding the continent of colonialism. First, it would defend the interests of independent countries and help to pursue those of still-colonized ones. Second, it would remain neutral in terms of world affairs, preventing its members from being controlled once more by outside powers. 
The OAU strategy vis-à-vis white minority regimes consisted of two forms of activity. First it involved diplomatic action, both in Africa and in the United Nations whose objective was principally to impose sanctions on and to isolate the target regimes. Second the OAU strategy entailed financial and material support to liberation movements fighting white supremacist governments (van Walren, 1999). It created the OAU Liberation Committee, based in Dar es Salaam, Tanzania, to channel assistance to black nationalists. Individual African states, notably Tanzania and Zambia, voluntarily provided rear bases and training for guerrillas, while Angola, Mozambique, and Zimbabwe were the "front line" states.

According to van Walren (1999), it took until the late 1970's for South Africa to be faced with a binding embargo. Boycott measures against the apartheid regime were taken relatively early on in the symbolic fields of support and culture. The OAU's sanctions policy consisted mainly of attempts to increase the isolation of the apartheid regime

At the Addis Ababa conference it had been resolved to:

- Break off diplomatic ties with Portugal and South Africa

- Prohibit imports from these white minority led countries

- Close ports and airfields to South African and Portuguese planes and shipping and forbid their aircrafts from over-flying African states.

The OAU strategy implied that not only should all member states agree to the means in which it sought to eradicate white minority rule in southern Africa, but it 
assumed that all members were in similar economical, geographical and military position as regards to the target regimes. Upon independence in 1966, Botswana became a member of the OAU. It argued that it could neither cut its links with South Africa, nor could it afford to harbor guerillas of liberation movements in view of its economic, geographical and military vulnerability. Botswana thus claimed the right to formulate its policies independently of the OAU, such as banning guerillas from its territory. Botswana's refugee policy noted that the progress of the country towards becoming a democratic, prosperous and non-racial country could only be safeguarded by the strictest neutrality in its dealings with its white minority led neighbors: South Africa to the south, Namibia to the west, Rhodesia/Zimbabwe to the East and Northern Rhodesia/Zambia to the north. It acknowledged that all its neighbors were more powerful than itself bit emphasized that this was a "counsel of caution but not of timidity" (Masire, 2007:266). It however agreed to provide asylum to persons who would face loss of liberty as a consequence of political opinion if they returned to South Africa. In his memoir Very brave or Very Foolish, former Botswana President Sir Quett Ketumile Masire (2007) acknowledges that although Botswana emotionally and sentimentally empathized with the plight of the black nationalists of South Africa to remove discrimination, improve black empowerment and political equality, they pursued a pragmatic approach, harmonizing their refugee policies with the UN Convention on Refugees and working through the organs of the United Nations rather than bilaterally. This act by Botswana although morally ambiguous, was a way to safeguard Botswana's interests and institutions. 
However, Botswana came under fire with apartheid South Africa over its perceived willingness to provide safe haven for the African National Congress (ANC) military wing, Unkhonto We Sizwe (MK), as well as various other black nationalist groups like the Black Consciousness Movement of Azania (BCMA). Although Botswana officially barred ANC use of its territory as a base for assaults against South Africa, the ANC dishonored this policy throughout the 1980s, provoking several small-scale attacks by the South African Defense Forces (SADF) against ANC bases in Botswana. Although Botswana did express rhetorical condemnation against apartheid, it remained geographically and economically too vulnerable to South Africa deterring it from implementing any sanctions against South Africa, the only OAU member to do so. Furthermore, through SACU it maintained extensive but unpublicized trade relations (Brynes, 1996). This dissertation argues that Botswana neutrality towards apartheid South Africa can be viewed within the context of attempting to maintain institutional development in Botswana.

\section{Botswana-South Africa Relations and Domestic Developments in Botswana}

South Africa remains Botswana's biggest neighbor and largest trading partner even in post-colonial times. Access to the sea remains exclusively through South African territory and up until 1976, the Botswana economy utilized the South African rand. Employment in and remittances from South Africa played a larger role at independence than cash employment at home. According to Masire (2007) the entirety of Botswana's capital was in the Imperial reserve in Mafeking, South Africa. 
Apart from being a strong economic player, South African hegemony in Botswana also plays out via its cultural influence. Botswana citizens read South Africa media, consume South African products, support South African sports teams, watch South African television shows and listen to South Africa music. The Botswana Broadcasting Corporation only hosts one television channel and South African Broadcast channels are widely available free of charge over Botswana airwaves, if a Motswana purchases a receiver. Ramidemoosi of the Botswana Ministry of Foreign Affairs and International Cooperation acknowledged the cultural links, particularly because of Tswana in South Africa who are greatly represented.

However, apart from the trade arena, post-apartheid South Africa's relations with Botswana have not yielded much influence over domestic developments and institutional development in Botswana. Botswana has maintained autonomy over its domestic affairs, even countering South Africa over issues such as the crisis in neighboring Zimbabwe. However, one key tie that Botswana still has with South Africa is the company De Beers, founded by former Cape Colony Prime Minister Cecil Rhodes. The following section will discuss in depth how De Beers remains a key agent in Botswana's institutional quality. 


\section{State - Firm Relations}

The third type of relationship that this dissertation is concerned with is that of states and important non-state actors. The contemporary international system is occupied by several mutually unique actors, including nation-states and multinational corporations $^{37}$. States are territorially defined and provide a framework for the political, economic, social and cultural activities of domestic actors, in addition to pursuing national interests in order to promote the welfare of their population. Multinational corporations (MNCs) on the other hand, expand their operations irrespective of state boundaries and cope with diverse political, economic, social, and cultural environments of acquired markets. Like all other firms, multinationals are driven primarily by private interests based on economy of scale, effective management, and global economic trends (Steinbockova 2007). In sub-Saharan Africa, there exists an asymmetry in the relationship between states and multinational corporations, particularly those whose economies are based in the extractive industries. This is apparent in Botswana's dealings with De Beers, which will be analyzed in-depth in a subsequent section. This section provides analytic background to the concept of state-firm relations.

According to Kempton and Du Preez (1997) states' strategic interests have evolved from primarily being the pursuit of power over territory, to increased competition for wealth within territories. As a result, wealth has become a primary end of statehood and no longer just a means of territorial expansion. They argue that states became the custodians of wealth creating capabilities of the institutions within their

\footnotetext{
${ }^{37}$ Although multilateral organizations, non-governmental organizations and other external actors are important, they have little significance to this analysis.
} 
jurisdiction. One major result of this reorientation of state goals heralded a new partnership as well as a new competition with transnational firms (ibid). States have become dependent on transnational firms as they possess the capital, technology, expertise, and access to global markets that states require to transform their resources and labor into domestic wealth. Transnational firms provide states with technology, access to global sources of capital and access to major markets. Similarly, firms cannot function without the labor and raw materials which only states can provide. However due to the dependency of states on firms to achieve basic developmental goals, weaker states have found this juxtaposition of states and firms challenging particularly in terms of the amount of clout a multinational company can exert over a state.

Vernon (1971) argues that the state no longer possesses sufficient control over its economic affairs due to the fact that MNCs have proven the ability to provide domestic economic welfare as well as establish effective production of goods on a much more efficient scale than the governments. Two major propositions back up Vernon(1971)'s claim that the majority of governments are unwilling or unable to sacrifice the advantages that transnational firms bring to the economy; and that most states are bound by the global strategies of the MNCs and as a result are unable to respond to the provisions of their home state's jurisdiction. As a result, Vernon views the preponderance of MNCs as heralding the decline of state sovereignty. De Beers's infiltration over the most important industry in Botswana provides insight into how a weak state can be vulnerable to a powerful multinational company. 
Steinbockova (2004) reveals some interrelated aspects of the relationships between MNCs and nation-states from the literature. She argues that the costs and benefits associated with MNCs tend to be unevenly distributed across states, and challenged Vernon's assertion that MNCs and states are partners in development. This concern is at the heart of dependencia theories. Steinbockova (2004) alleges that accepting foreign private investment from developed states increases economical technical and cultural dependency of less developed countries. She cited Poynter (1985) who compares foreign direct investment and the presence of MNCs in developing countries to a Trojan horse through which the outside states can exert their influence on the host nation. .Steinbockova (2004) also argues that the weakening of national control over the economy and economic actors due to multinational enterprise's increasing role as the primary agents of interdependence, limits states control over domestic economy. MNC's are concerned with raising profitability and growth while states seek to include the operations of private sector into their policy strategies how to promote economic and social welfare of their citizens. De Beers' partnership with the Botswana government is reminiscent of this, as will be elaborated in the subsequent section. The company made strides towards maintaining the status quo in order to increase its share of benefits from the extractive industry in Botswana.

According to Leonar, (1980) multinationals stimulate certain patterns and processes of economic development that may have long term political reverberations, particularly for developing countries. They tend to promote economic development primarily in the modern sector, thereby reinforcing existing societal dualisms. They perpetuate bias towards the production of certain products, stimulate certain consumption 
and utilize central technologies, all of which may help to further increase the gap between the rich and the poor, the urban and the rural. As a matter of self-interest, multinational corporations will normally use their economic power in bargaining to extract concessions from governments on matters such as protection, tax rebates, investment allowances, choice of factory sites, and access to resources. Because they deal primarily with elite groups in the business and governmental sectors, they may encourage patterns of external orientation that may alienate these groups from the wants and needs of the masses. Moreover, multinational corporations may well tie a developing country into international networks of mutual interdependence that will narrow social choices within as well as among countries.

Apter (1980) developed a set of hypotheses about multinationals and developing countries which he deems middle-range hypotheses. First, he argues that with a greater degree of modernization, a state becomes more vulnerable to the influence of advanced industrial societies, particularly through multinational corporations. Second, as the degree of modernization increases and multinational presence, so does the political stability. Third, in the tertiary stage of modernization if a multinational is to protect and enlarge its investment, it becomes necessary for it to meddle politically (Leonar 1980:464). This dissertation's findings greatly reflect these three prescriptions. Botswana's close partnership with De Beers has been viewed as being pro-Western and has attracted further investment into the country. De Beers has also facilitated expanding its own investment and economic aspirations by intervening in Botswana's politics. The following section will further examine the impact of De Beers on institutional quality in Botswana. 


\section{THE ROLE OF DE BEERS IN BOTSWANA'S DEVELOPMENT}

There have been many constants in the Botswana story - the fact that the Botswana Democratic Party has been in power since independence in 1966, the fact that the economy has, to a large extent, failed to diversify to other sectors, and the close relationship that the Botswana government has maintained with De Beers. This section examines the role and impact that the close relationship with De Beers has yielded at these pivotal points. It begins with a broad analysis of De Beers as a whole, particularly within its context as a multinational of South African origin, and then examines the role of the multinational in Botswana's economic and political institutional development.

De Beers has garnered critical acclaim as the world's leading diamond company. Since its inception in 1888 , it has lived up to this reputation through unrivalled expertise in the exploration, mining, and marketing of diamonds. De Beers has dominated the diamond industry, diamond mining, diamond hops, diamond trading, and industrial diamond manufacturing sectors for over 120 years. By the mid-1960s, the company was active in every category of industrial diamond mining: open-pit, underground, large-scale alluvial, coastal and deep sea with the bulk of mining operations occurring in Botswana, Namibia, South Africa and Canada. The company's founder Cecil John Rhodes got his start around 1871, and by 1889, De Beers controlled diamond distribution channels via strategic negotiations with the London-based "Diamond Syndicate," an alliance of diamond merchants; based on the maintenance of high prices and a notion of scarcity (Kretschemer, 1998). The company gained a reputation for utilizing monopolistic policies directed at the manipulation of the global diamond market via the employment of various 
strategies. First, the company convinced independent producers to join a single channel monopoly. Second, it flooded the market with diamonds similar to those of producers who refused to join the cartel. Third, it purchased and stockpiled diamonds produced by other manufacturers in order to control prices through supply, (Lopus, 2003). These three structures largely remained unchanged, and to a great extent have benefitted Botswana though stabilizing the global price of diamonds. Sight holders purchased the diamonds through the Central Selling Organization (CSO), a subsidiary of De Beers, which acted as a quality regulator and set the market price. Historically, the CSO controlled over 80percent of the world's diamond trade, however recently that share has dropped to a range between 65 and 75percent (Mail and Guardian, Nov 4, 2011).

De Beers remains a tight-knit organization. Diamond producers are nominally diamond mines that are state-run in countries whose economic outputs are heavily skewed towards the extractive mining industry. These producers relationship with the company has been beneficial in insuring a steady inflow of foreign direct investment. Diamond dealers, on the other hand, enjoy predictability of prices and their continual increase over time, a burden carried only by consumers (Kretschemer, 1998). Ultimately, De Beers mainly benefits charging extortionate fees to diamond producers and charging discretionary process to diamond merchants, a situation that has greatly stabilized price fluctuations of diamonds to the benefit of producer countries like Botswana. 


\section{De Beers in Botswana}

Botswana hosts the world's largest, most profitable and longest-life diamond mines in the world. Carat-wise, it is the most valuable diamond producer with a mined output in 2006 of 34.3 Mct (mega carats) valued at US\$3.38 billion at an average of US\$98.50/cy, a 7.5percent increase over 2005 when 31.9 Mct, values at US\$3.13 billion, was mined. This output amount represents about a quarter of the world's entire diamond production by value. It is widely claimed that sound macroeconomic policies and prudent use of diamond reserves have placed Botswana among the fastest developing economies in the world. As of 2007, the mining sector accounted for 90percent of the country's total export earnings, 50percent of government revenue as well as a third of the country's GDP. It is also widely cited that what facilitated this success was Botswana's dominant relationship with the De Beers cartel. With the demand of diamonds increasing and very few discoveries made globally, Botswana has had unprecedented leverage in the diamond market, negotiating lucrative contracts with De Beers over the course of five decades. (Even-Zohar, 2007). Figure 6.1 shows World Diamond Productions in $2011^{38}$.

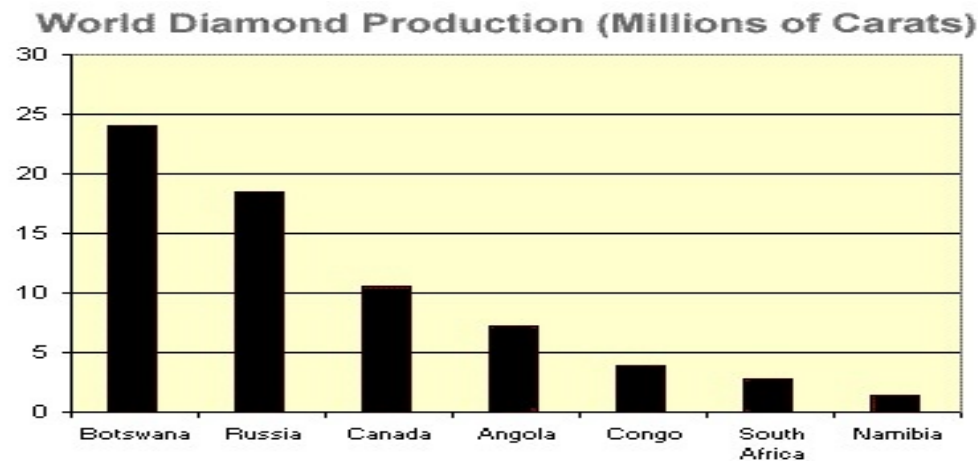

Figure 6.1 shows World Diamond Productions in 2011

\footnotetext{
${ }^{38}$ http://geology.com/articles/gem-diamond-map/
} 
Botswana's second president Sir Quett Ketumile Masire (2007), in his memoir Very Brave of Very Foolish: Memoirs of an African Democrat asserts that since the 1950's Botswana dealt exclusively with Anglo-American/De Beers groups of companies. At the time, Anglo American Plc. was one of the world's largest and most lucrative mining companies, with the largest share of gold production. De Beers was the largest producer of diamonds, controlling the vast majority of the world market share via its Central Selling Organization (CSO). Both Anglo and De Beers were controlled by the Oppenheimer family. De Beers began prospecting for diamonds in Botswana in 1955(Even Zohar, 2007). The pioneer team of geologists was led by Gavin Lamont. A 12 year prospecting led to the discovery of kimberlite, an ore that is indicative of the presence of diamonds, in Mochudi, and Harry Oppenhiemer informed Seretse Khama and Peter Fawcus about this discovery believing it was a viable deposit. In 1967, they continued prospecting, moving further north into Botswana and the first Orapa discovery was made in March 1967. The Orapa pipe ${ }^{39}$ was the world' second largest pipe by area, after the Mwadui pipe in Tanzania, with a surface area of 146ha. According to Masire (2007), De Beers undertook the financing and execution of the entire diamond project including the infrastructure, mine and township, which was developed as a closed town for reasons of diamond security. In reaching the agreement with De Beers, Quill Hermans led the negotiating team. In 1967, the government received 15percent of the equity in the mining company in exchange for granting the mining lease, a 10percent royalty on diamond sales and income tax on the profits of the mine (Masire, 2007). This is a unique arrangement seeing that Botswana is the only government in the world to have a stake in

\footnotetext{
${ }^{39}$ The word "pipe" here refers to a "kimberlite pipe", a subterranean geological feature known to contain precious and semi-precious gemstones.
} 
the company. This deal is considered particularly beneficial to Botswana as it increased the government's bargaining power in negotiations and allows it to gain profits from abroad. Neighboring Namibia only places a representative - the permanent secretary of the Ministry of Mines and Energy, in De Beers' board (Rieckeman, 2008). According to BenchMark, De Beers paid Botswana \$20 million for a diamond concession in 1969, an investment which returned $\$ 60$ million in profits that same year. De Beers Botswana Mining Co was then established to develop the deposit and the mine went into production in 1971, this was about the same time that the Indian diamond industry was taking off, becoming an important user of the relatively cheap Orapa rough. Orapa's production averaged 2.5 Mct/y in the 1970s.

In 1972, another mine was discovered Jwaneng mine, which was to be the largest gem diamond mine in the whole world. Ultimately, the discovery of the second mine gave Botswana the leverage to renegotiate the relationship with De Beers ${ }^{40}$. Between 1967 and 1973, De Beers's geologists located three richly diamondiferous kimberlite pipes in Botswana, with the eventual result that this poor under-populated nation in the Kalahari Desert would become the third in the world in diamond production as measured by carat weight, behind only Zaire (now Democratic Republic of Congo) and Australia. In 1975 Lethlakane mine began operations.

Botswana has led the world in diamond production as measured by value since the early 1990s. Many kimberlites occur in the country besides the main three (Orapa, Letlhakane and Jwaneng) and many smaller mines are now in operation. Nearly all

\footnotetext{
${ }^{40}$ Secrecy surrounds the content of all negotiations between De Beers and Botswana. This information is not available to the public.
} 
diamond production is controlled by the Debswana Diamond Company, a joint venture firm of which 50percent is owned by De Beers and 50percent by the government of Botswana. Debswana emerged from a pact to govern the distribution of diamond revenue between the government and De Beers. The agreement's contents have largely remained confidential. In fact, secrecy and anonymity have shrouded the multinational company to the extent that most people are now paranoid of its dealings (Mokhawa, 2005). The Botswana government is estimated to take about 75 percent of diamond mining income typically in the form of royalties, taxes and dividends. The Central Selling Organization (CSO) - De Beer's marketing arm, carried out the marketing of Botswana diamonds. Botswana currently contributes 60 percent of total sales through the CSO (ibid). Botswana's original mining venture through Orapa was lucrative to the point that De Beers could recoup its investment within two years of the mine's operation. Accordingly, the Botswana government as able to negotiate its shareholding in Debswana from 15 to 50 percent. This invigorated a dividend policy that took full advantage of revenues to its fiscus ${ }^{41}$.

According to Neo Moroka, the CEO of De Beers Botswana, the Botswana government and De Beers created Botswana Diamond Valuing Company (BDVC), a joint venture between De Beers and the investment arm of the Botswana government, the Botswana Development Corporation. In 1987, Botswana Mining Company (BMC) was given a shareholding of 5percent in De Beers Group, and through that the government of Botswana was entitled to sit on the De Beers board. The BMC was renamed in $1992 \mathrm{De}$ Beers Diamond Company. In 1982, of significance was the completion of Orapa House

\footnotetext{
${ }^{41}$ The only other $50 / 50$ joint venture that De Beers has is with the government of Namibia called NamDeb.
} 
which is an iconic diamond building accommodating the sorting and valuing of diamonds. In 1998 De Beers dual listed its shares on the Botswana Stock Exchange, only to delist in 2001. The same year, the company was privatized and the Government of Botswana took in a 15percent stake. The following year, Damtshaa mine began operations. In 2006 the government established the Diamond Trading Company Botswana (DTCB). At that time there was a sales agreement that allowed De Beers to sell diamonds until 2010. Also De Beers in 2007, of significance DTCB in the interest of beneficiation, the DTCB signed agreements with cutting companies. Sixteen companies were licensed in 2007 to cut and polish diamonds and these companies were to cut US\$500 million worth of diamonds. The DTCB building was open in 2008.

\section{De Beers' Impact on Economic Development in Botswana}

It is without doubt that De Beers has played a central role in transforming Botswana's geologic luck into economic development. According to De Beers Botswana's CEO Neo Moroka, the company has a simple operating philosophy - "living up to diamonds". This has enabled the company to make a lasting contribution to both national and community development. This contribution has mainly been a result of mining infrastructural development as well as a translation of the De Beers' commitment to corporate social responsibility reflected in a number of community development projects. More importantly with the potential that De Beers saw in the fact that it was a long term project not a short term. With the demand of diamonds increasing and very few 
discoveries made globally, Botswana found itself with leverage in the diamond market, negotiating lucrative contracts with De Beers over the course of five decades.

Debswana is the government's single largest employer. It employs 600 workers at its mines across the country and has facilitated the economic growth of Botswana. Over the past decade, on the back of a persistent global commodity price boom in diamonds, the Botswana economy grew annually between 12 and 13 percent. The 1980s saw the burgeoning of hospitals, schools and roads. Botswana followed a statist model for the delivery of universal free health and education until 2006, when extensive privatization began.

Perhaps De Beers' best impact to Botswana's economy has been the fact that its monopolistic practices have increased predictability and stability of governmental revenue streams. This has greatly improved the country's export earnings, with gross official reserves as high as USD 8.8 billion in October 2011; an equivalent of about 19 months of imports of goods and services. Botswana's outstanding external debt level is relatively low and sustainable, despite its recent rise following the global economic and financial crisis, and its credit rating is relatively high. In lowering its external debt, the country has ongoing fiscal consolidation measures that focus on completing current infrastructure projects and limiting expenditure on high return projects (Africa Economic Outlook, 2013). 


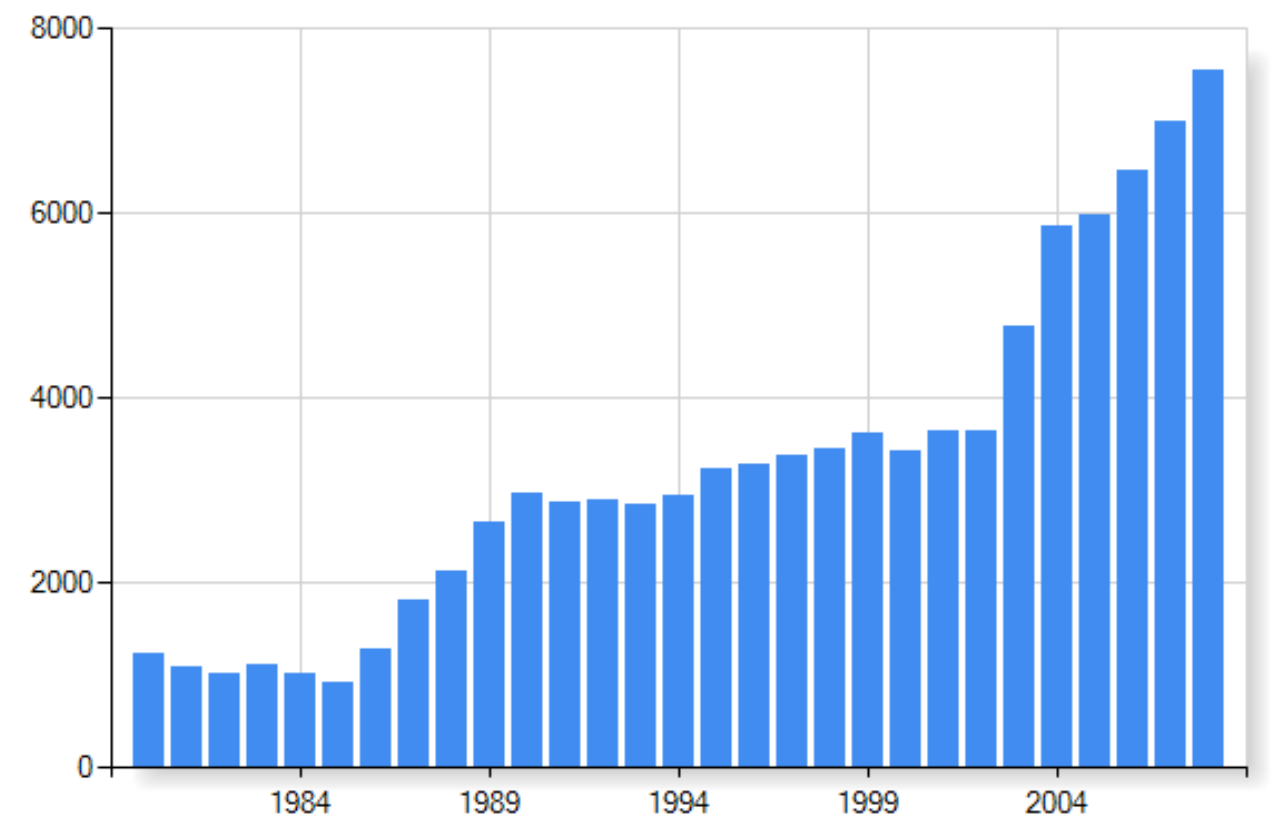

Figure 6.2 Botswana trend in GDP per capita (USD) (1980-2010)

Source: International Economic Statistics

De Beers has had a negative impact on Botswana's economy through active efforts to stifle diversification from the diamond and mining industries. Even-Zohar (2007) alleges, without elaborating, that De Beers has vehemently opposed Botswana's aspirations to diversification particularly in the manufacturing sector ${ }^{42}$ and has given 'lipservice' to domestic beneficiation, assuring that manufacturing would not be profitable. He argues that the company did everything to prevent the establishment of token manufacturing units. On the issue of Botswana diversification, Gary Ralfe, managing director of De Beers stated:

\footnotetext{
${ }^{42}$ Botswana had limited manufacturing. From 1994 to 200 they hosted a Hyundai car assembly plant in Gaborone. However, in 2000 it was relocated to South Africa.
} 
"... Particularly in the case of Botswana [the absence of manufacturing] is a recognition of economic realities. Botswana's best interests are served precisely by having diamonds polished in the places where they can most economically be polished. Botswana is such a major [rough] producer and the Botswana government has such a clear view about these matters, that they recognize the truth of this. For a major diamond producer like Botswana, it would be national folly to prescribe that any percentage of their diamonds needed to be beneficiated locally. What Botswana, as the world's major producer of diamonds needs to do, is to ensure that diamonds reach the place where they can achieve the highest price and that gives by far and away the best returns in terms of fiscal revenue." (Grynberg, 2013:5)

The Botswana Federation of Trade Unions argues that “...broad-based economic development can only be achieved when all Botswana citizens have access to the means of production. This invariably implies that government should empower Botswana citizens to participate in economic development as creators of wealth. Botswana citizens should be weaned from the culture of servitude and instead, an entrepreneurial culture should be promoted" (van Wyk, 2009:27).

De Beers's change of heart toward beneficiation in Botswana emerged from the reduction in its market share. Figure 6.3 shows De Beers lowering market share over a 25 year period: 
The Decline of De Beers Market Share (percentage)

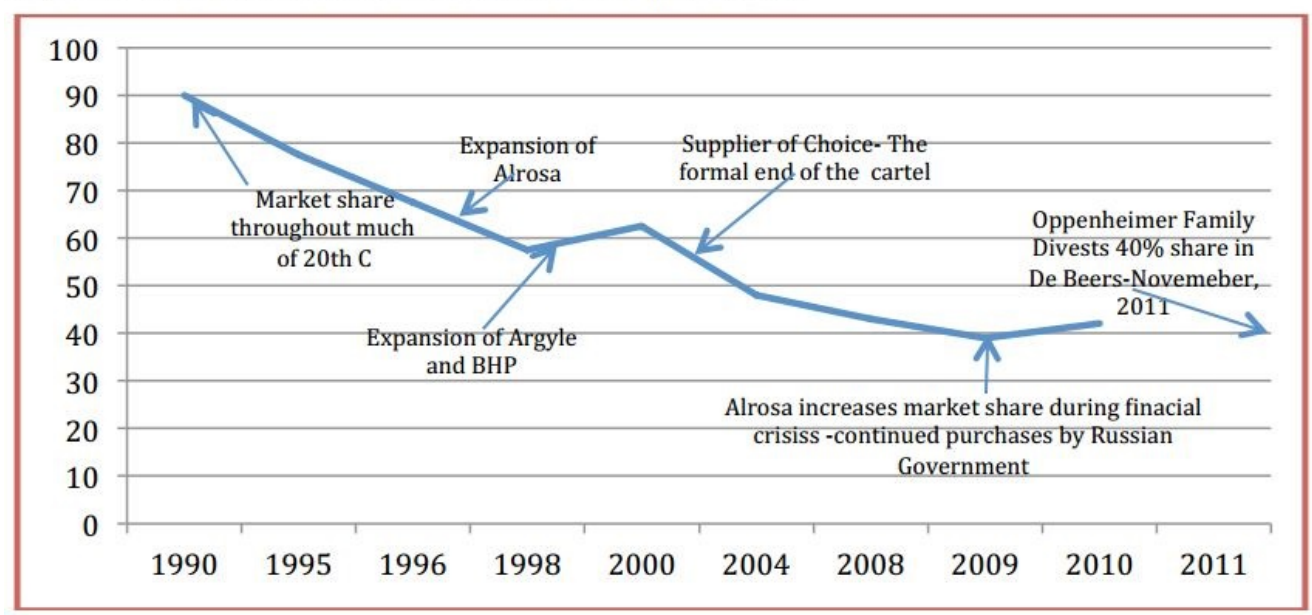

Figure 6.3: The Decline of De Beers Market share percentage (1990 -2011) Source: Grynberg (2013:4)

Currently, ongoing programs to address Botswana's economic challenges include the National Economic Diversification Drive Strategy (NEDDS). NEDDS intends to improve the productive capacity of domestic firms and is expected to make considerable contribution to job creation and economic growth in Botswana. Furthermore, Ipelegang, a labor intensive government initiative was launched to provide for youth employment and create development funds in addition to providing social safety nets, (Africa Economic Outlook, 2013).

It is difficult to argue that Botswana has not benefitted from the partnership with De Beers, but the issue of beneficiation has brought light the inadequacies of the partnership. Unlike in neighboring Namibia where beneficiation and downstream processing has been promoted in first place to generate employment, it is only recently that De Beers finally relented and agreed to have diamond beneficiation in Botswana by 
moving the Diamond Trading Company (DTC) from London to Gaborone, enabling some beneficiation. Beneficiation, i.e. lowering the dependence from extractive mining to other activities such as polishing and cutting, has for the most part not progressed, not because of the government's lack of willingness, but mainly because of De Beers dragging its feet and sometimes even sabotaging the efforts. According to the Sunday Standard (2006-12-04), De Beers sabotaged the Belgian diamond cutting company, Mabrodium, by selling rough diamonds at an exorbitant, non-negotiable price. The company left without ever making a profit. Similarly, the Teemane cutting plant set up in Serowe and Lazare Kaplan complained that their cutting factory in Molepolole was making losses because the diamond mix it bought from De Beers did not make for a viable enterprise. However when compared to other countries where De Beers operates like Namibia or where diamond companies are nationalized like Endiama in Angola the scale of production of Botswana through its partnership with De Beers is unprecedented, hence, has been greatly beneficial.

The cartel nature of De Beers meant that there were no competitors for Botswana to consider as alternative partners. Within this context, De Beers can be given credit for assisting Botswana to achieve its level of economic development as well as its strides towards facilitating community development and addressing the HIV/AIDS issue in the country. However, where it suited De Beers, the company thwarted efforts for Botswana to diversify its economy as well as to beneficiate, situations that would have led Botswana to be less dependent on the extractive diamond industry and would have created employment for Botswana citizens. 


\section{De Beers and Botswana's Political Development}

As the government of Botswana's partner of choice, De Beers has been central to the development of the political landscape in Botswana. A grim opinion of Botswana's source of political stability emerges through contentions that it may be artificial stability orchestrated by De Beers in order to perpetuate an environment in which it would reap optimal profits, the goal of many private companies. Evidence of this is mainly in the form of assertions of party funding, giving the Botswana Democratic Party an edge when it comes to elections. Many interview respondents argued that although elections in Botswana are for the most part free, they are hardly fair, due to De Beers being a benefactor to the BDP at various points in the country's history. This is largely viewed as undermining the democratic process. This section evaluates the influence of De Beers in Botswana's political arena and analyzes its possible impact on political development in the country.

\section{De Beers and Political Party Financing in Botswana}

The overwhelming consensus among interview respondents on the state of Botswana's democracy, was that in Botswana elections are free, but grossly unfair, thus undermining the democratic process. The issue of party funding in Botswana has been the contentious one. The main point of disputation is the symbiotic relationship that seems to exist between De Beers and the ruling Botswana Democratic Party (BDP). De Beers' involvement with Botswana politics goes back to the early 1980's, at the beginning of the Masire presidency. By this time, Botswana's crucial socio-economic institutions were 
already in place. However, De Beers played a decisive part in influencing the quality of those institutions yielding both positive and negative results.

According to the Sunday Standard (January 18, 2010) on the eve of the 1984 elections De Beers helped put together a financial bailout plan for the second Ketumile Masire administration. Behind this bailout were De Beers's directors Peter Layden, former Debswana Managing Director, Louis Nchindo, and a South African lawyer, Len Fisher, who had handled the De Beers patent dispute with GE years before. De Beers procured an expatriate farm manager for Masire's farming company, GM Five, as part of the rescue plan. De Beers helped secure a P 186228 bank loan for Masire's GM Five from Barclays Bank. During his subsequent term in office, GM Five owed De Beers close to P 1 million. In September 1987, GM Five made a request to De Beers for a reduction of the total amount owing of P805 910 by the costs associated with the farm manager of P164 466 and the amount paid directly to Barclays of P186 228 leaving a net amount owing of P455 216. GM Five proposed to round the figure up to a round P500 000. In response, De Beers placed a moratorium on the repayment of the loan P500 000 for a period of five years, allowing repayment of equal installments over the period.

A decade later, De Beers, seeing BDP's growing unpopularity and Masire's worsening finances as potentially explosive, needed a plan to assist in securing a BDP victory in the 1999 election (Good, 2008). De Beers and Anglo American engaged a consultant; University of Natal's Professor Lawrence Schlemmer to assess the BDP's prospects and the secretive Schlemmer Report duly recommended that new leadership was essential. The consultancy recommended that Masire should step down to pave way 
for a newer generation of leaders in the form of Festus Mogae. With GM Five still heavily in debt, Masire was reluctant to relinquish power. As a compromise, De Beers offered more money to GM Five, ensuring an adequate retirement package for Masire evidenced by a P4million transfer from De Beers. This transfer was done with the assistance of a ghost company the Clairemont Corporation in Panama to GM Five, under the pretext that they were buying into the company. Proceeds from the fictitious sale of shares would then settle GM Five loans with Standard Chartered Bank, National Development Bank, Botswana Agricultural Marketing Board and other sundry liabilities. De Beers upheld that the entire scheme was orchestrated by former Debswana Managing Director Louis Nchindo and they did not benefit anything out of it (Sunday Standard, 2012-01-18).

In a written response to the allegations in 2010, De Beers's spokesperson, Chipo Morapedi, stated that:

"While it is difficult to comment on the specific sequence of events that occurred more than 25 years ago, it is true that, given the company's investments and experience in managing farms at the time, we were able to provide management assistance and a loan facility to former President Sir Ketumile Masire."

The statement from De Beers further said:

"The purpose of the loan was to help the then head of state by relieving him of the burden of debt and providing him with resources for the farm to be independently managed and so enabled him to attend to the duties of his office and matters of national 
interest. Louis Nchindo put the idea to Sir Ketumile and also recommended the assistance to the company. This was done in his capacity as an employee of the company at the time. In the present day and age, the De Beers family of company's operates in a completely different environment with clear policy guidelines governing donations and for disclosure."

De Beers was quick to add that the purpose of the loan was to help the president by relieving him of the burden of debt in his troubled farm in order for him to concentrate on matters of office and national interest.

Debswana managing Louis Nchindo has since died under mysterious circumstances in Gaborone, while being tried for corruption charges (Mmegi, 2010). It was during his trial that evidence of De Beers loans to senior government officials emerged, with many believing his deaths may have resulted from a fallout caused by his role in whistleblowing or spilling the beans.

According to interviews by the Botswana Congress Party (BCP)'s Dr.

Gobotswang and Dr. Taolo, the bane of Botswana's democracy is the absence of legal instruments to disclose the sources of party finance. Bhattacharya (2012) argued that there exists a strong correlation between how much a party spends and its electoral performance. A study on British elections done by Johnston and Pattie (2008) estimated that an extra $\$ 3.58$, of electoral spending corresponds to one additional vote. Following this formula, if this is correct then the extra P5 million (\$623000.00) more that the BDP got from De Beers would result in 174000 extra votes. Had an even financial playing field existed, the outcome of the election could well have been different. Although the 
calculations may be imprecise, the point remains: there is a significant inequality of wealth between political parties in Botswana and this certainly influences electoral results and political advantages. Campaign spending this is a way of deploying one's resources so as to alter people's voting intentions. The more elections are decided by arguments, the more democratic the political system is, the more other influences intrude, the less democratic it becomes. If campaign spending becomes a more significant determinant of electoral success, this moves us away from democracy (Bhattacharya, 2012). Both Dr. Gobotswang and Dr. Taolo argue that unfair party financing is the reason for opposition parties in Botswana being weak, and for the BDP maintaining an unfair advantage at elections.

It is the view of this dissertation that institutional development in the main sector of the Botswana's economy, its diamond industry, has greatly been influenced by a sense of "obligated loyalty" to De Beers. BenchMark, a Christian NGO based in South Africa, argues that "The great danger in Botswana is that because of the 'marriage' between De Beers and Botswana, and the dependence of Botswana on a single commodity produced by a single corporation, the state (particularly where a single party has controlled the state for an extended period) begins to behave as if it were a corporation placing the country under the near total control of the state under the management of the dominant party" (Mmegi, (09/23/2009)). In the case of Botswana, institutional choice and the relative longevity of institutions of private property have greatly been shaped by De Beers. Such institutions protect the property rights of current investors and provide political stability, albeit artificial. However, De Beers' activities have weakened the constraints on political 
elites, particularly within the ruling BDP. This inadvertently affects the participation of a broad cross-section of the society. Although this dissertation does not go so far as to claim the ineffectiveness of institutions of property rights in Botswana, which it believes have generally been effective when compared to extractive institutions in other resourcerichcountries, it argues that the biased loyalty to De Beers and Debswana by politicians especially the presidency, and the general ignorance about the diamond industry by the man on the street, have perpetuated the status quo and limited competition.

\section{CONCLUSION}

This chapter has attempted to illustrate the role of exogenous actors in determining the setting into which political and economic development in Botswana played out. Influences stemmed mainly from Botswana's colonial engagement with Britain, its relationship with regional hegemon South Africa, and its symbiotic relationship with the diamond cartel, De Beers. Botswana's limited colonial engagement can be understood primarily in comparative perspective, and this chapter borrowed influences from the South Korea and experiences as to how the actions of a colonial master can greatly shape the resultant institutions and developmental capacity of a country to either be developmental and cohesive capitalist, or to be neopatrimonial. However, Botswana experienced the same type of colonialism as Nigeria and adopted similar institutions upon independence but with totally different results, thus limiting the utility of the colonialism argument. Botswana's relations with South Africa were more a result of a multi-faceted relationship between the South African government's bid to limit 
Afrikaner encroachment as well as its employment of the ideology of separate development. South Africa's control of trade in southern Africa, particularly within the context of the South African Customs Union, is the greatest manifestation of South Africa's hegemonic aspirations, affecting Botswana directly. However, South Africa's impact was limited to trade institutions and little evidence of deliberate steering of Botswana's institutional development exists elsewhere.

By far the greatest external effector was De Beers, whose involvement in Botswana at a pivotal moment in history, helped transform Botswana from a poor arid country based on agriculture to a middle income developing country. De Beers' influence can also be seen in its dealings with the Botswana Democratic Party, with evidence showing an inclination towards facilitating political stability and political financing in order to enhance De Beers' own goals. This dissertation argues that De Beers's involvement in Botswana's economy helped transform Botswana into one that is competitive, and helped the country achieve sustained rates of economic growth over four decades. However, evidence exists to show that De Beers' involvement in Botswana's political institutions had the opposite effect. The company undermined democracy by providing unfair advantages during the election process to support the ruling BDP. Hence, one may become skeptical to the robustness of Botswana's institutions as De Beers' intervention hints towards a "negative peace." De Beers has for decades supported what Kenneth Good referred to as a "structured autocracy" and have choked Botswana's political institutions to an extent where there is limited civil society and media, dominance of a single political party, extensive executive authority and 
increased marginalization of minority groups such as the BaSarwa. De Beers has blurred the lines between what counts as government interests and what counts as BDP interests, thus altering the political climate of the country into a de facto one-party state.

Furthermore, De Beers stalled in beneficiating diamonds to Botswana; a situation which would have greatly benefitted the country's poor by creating employment. In summary, rather than hint towards strengthening Botswana's institutions, the De Beers factor provides evidence of undermining the democratic process in order to pursue its own interests of making profit.

This chapter concludes by arguing that the evidence collected greatly undermines the hypothesis that Botswana's institutional quality is a result of British colonialism, South Africa hegemony or De Beers's partnership. Although these three actors contributed to Botswana's economic and political development, they were neither responsible for nor disruptive of Botswana's institutions and institutional quality. 


\section{CHAPTER SEVEN}

\section{ANALYSIS, APPLICATION AND CONCLUSION}

\section{Synopsis of Dissertation}

Botswana has garnered analytic attention for being an anomaly to the norm of missed opportunities for the resource-rich countries of the developing world. This dissertation confronted the question of why Botswana, a small landlocked country, managed to build institutions that assisted in it translating its natural resource wealth, diamonds, into a motor of one of the fastest growing economies in the world for nearly half a century, while maintaining a peaceful and democratic political atmosphere.

Botswana escaped three resource curses that have been studied empirically: the curse of violent conflict, the curse of underdevelopment, and the curse of authoritarianism. Beginning from a place of near - consensus that institutions play an intermediary role in determining the fate of resource-rich countries, this research in essence interrogated the sources of institutional quality in Botswana.

The research examined four variables that it assumed to have plausibly contributed to Botswana's high level of institutional quality. The variables were divided into two broad categories: endogenous sources and exogenous sources. Thus defined, endogenous factors encompassed those that originated from within the country, and have evolved over time within its system. In this research, the endogenous variables were identified as legitimacy and historical continuity, political culture and ethnic identity management. Exogenous variables, on the other hand, were those that originated from outside the state system, but were assumed to have had a profound impact on institutional 
choice, quality and development. In the case of Botswana these exogenous variables were identified as the type and character of British colonialism, the role of De Beers, Botswana's main economic partner, and the influence of the regional hegemon, South Africa.

The goal of this chapter is to reconcile the resource curse literature addressed in Chapters 1 and 2, with the substantive analysis of variables done in Chapters 3, 4, 5 and 6 , in order to evaluate the underlying reasons of what helped Botswana escape the resource curse through institutional quality. In doing so, a robust analysis of the significance of each variable in determining Botswana's institutional quality can be done. In the following section, I utilize the legislature as the institution of choice in tracing the processes of institutions at work in Botswana's diamond industry. I describe how those same processes help the understanding of, and provide context to the failure of other resource-rich countries which have exhibited the resource curse.

\section{Botswana's Legislative Oversight in the Diamond Industry: A Comparative}

\section{Analysis}

The legislature in Botswana is a key institution in determining decisions and policies surrounding the diamond industry. The supreme legislative authority in Botswana is the parliament, consisting of the President and the National Assembly. It acts in consultation with the House of Chiefs (Ntlo ya Dikgosi). The primary functions of Parliament are to pass laws, to scrutinize and monitor government policy, and to allocate funds for government expenditure. Botswana's legislature is greatly involved in the 
decisions that affect the country's extractive sector, principally the diamond mining industry that dominates the economy. The president's cabinet is selected from the legislative branch, with the Minister of Finance and Development Planning and the Minister of Minerals, Energy and Water Resources, being selected from this pool of elected officials. Because cabinet-level ministers have greater access to information and to the confidence of the president, they are more influential in the legislature. The Minister and Permanent Secretary of Finance and Development Planning and the Minister of Minerals, Energy and Water Resources and his Permanent Secretary, in addition to the Attorney General, the Governor of the Central Bank and the Office of the President, are all members of the board that represents the Botswana government in the public-private strategic partnership between De Beers and the government, Debswana.

According to Bryan and Hofman (2007), members of Parliament in Botswana are free to exercise their power of scrutiny over the diamond industry and perform legislative oversight in the mining sector. Recently, the parliament of Botswana has debated over and rejected a proposed beneficiation law proposed by the Shoshong Member of Parliament aimed at increasing the efficiency of diamond beneficiation in Botswana in light of the transfer of DTCI (formerly CSO) to Gaborone. Parliament settled for a policy instead of a hard piece of legislation (Daily News Feb 22, 2013). Parliament is however excluded from the negotiation of agreements between the government and the private sector and this is largely left to the "experts". For example, the renegotiation between De Beers and Botswana on 25 year lease renewals for the country's four mines was presented to members of parliament only after the final negotiation. As a result, 
parliament tends to be more reactive than proactive in the decision-making process (NDI, 2007). Parliament voted for Botswana to voluntarily enter the Extractive Industries Transparency Initiative (EITI) an international standard that ensures transparency around countries' oil, gas and mineral resources. In addition, it volunteered to join the Kimberley Process, an initiative to stem the flow of "conflict diamonds ${ }^{43}$ " though the certification of source of origin for every diamond sold on the world market (ibid).

The central piece of legislation regulating the diamond industry is the 1977 Mines and Minerals Act, amended in 1999. It streamlines the issuance of exploration and mining licenses, conferring three types of mineral rights: reconnaissance permits, prospecting licenses and mining leases, to either individuals or companies. According to an interview with Nchidzi Mmolawa, Deputy Permanent Secretary of the Ministry of Minerals, Energy and Water Resources, Botswana's legislation imposes a variable income tax of between 25 and 50 percent in companies, determined annually by referencing the mining company's profit ratio. The legislation allows the government to retain rights to the acquisition of interest in new mines for up to 15 percent. His colleague, Gabotshwarege Tshekiso, Chief Engineer at the Department of Mines added that applications for mineral rights are made to the Ministry of Minerals, Energy and Water Resources through the Geological Survey Department or the Department of Mines. All mining revenue in Botswana is considered to be "national" and is placed in the Central Bank account and dispatched to different governmental branches through National Development Plans (NDP). These plans are developed every six years by the

\footnotetext{
${ }^{43}$ A conflict diamond (or blood diamond) is a diamond mined in a war zone and/or sold to finance an insurgency, invading army's war efforts, or a warlord's activity.
} 
Ministry of Finance and Development Planning and include annual budgets and mid-term reviews. The Ministry of Finance and Development Planning has a central role in the development and implementation of the National Development plan.

Botswana's legislature monitors the performance of its extractive industry from decisions regarding the extraction of diamonds, to the allocation of funds obtained from the diamond revenue. Parliament has to approve the use of mineral revenues for the NDPs as is reflected in a speech by former President Festus Mogae to the African Development Bank’s 2008 Eminent Speakers’ Program.

"It was agreed between Cabinet and Parliament, that the mineral revenues would be used only for capital projects. In turn these were to be approved by Parliament in a National Development Plan. We had five, sometimes six-year rolling National Development Plans which were reviewed and updated every three years. Over the years, the definition of capital or development projects was expanded to include recurrent expenditure on education and training and health services. It was argued that these were part and parcel of human resources development and that human beings were the country's most precious resource. Hence, 95\% of Botswana students at tertiary institutions in and out of the country are paid for by government. For a new project to be implemented, it had to be included in the National Development Plan whose amendment had to be approved by parliament. This way, there was discipline in government expenditure and it minimized waste, certainly prevented extravagance on prestige projects. It also minimized or helped to minimize corruption. While the government initiated projects, determined priorities and responded to national emergencies such as 
frequent droughts, Parliament helped monitor the implementation of agreed policies and development priorities. The Government also allocated or gives subventions to District and Town Councils based on a formula, which takes into account population, geographical extent, climatic conditions, levels of development, etc. The strength of these arrangements is their transparency and accountability. These arrangements and practices are overseen by the constitutionally entrenched Auditor-General, the Public Accounts Committee of Parliament, Parliament itself, a free press and independent judiciary."

Source: Presentation by his Excellency the former President of Botswana, Mr. Festus G. Mogae on "Extractive Industries and Africa's Development: Lessons from Botswana” at the African Development Bank's 2008 Eminent Speakers program. (http://www.slideshare.net/simandef/extractive-industries-and-africas-presentation)

As is seen in President Mogae's speech, Botswana's legislature's role in its extractive industry goes beyond the management of diamonds. They approve where the money is allocated and prioritize which types of projects the money is spent on. This is telling of the level of scrutiny and participation that this institution plays in Botswana's escape of the resource curse. The management of resource revenues and creation of the National Development Plans involves a broadly based consultative system. The lower house, the House of Chiefs (Ntlo ya Dikgosi), reviews all decisions made by parliament and provides advice. Most of their chiefs' advice is aimed at issues that affect tribal organization and property, as well as those that affect customary law. 
This dissertation is of the view that Botswana's institutional success, as is illustrated by the legislature's role in the resource industry, is a result of both endogenous and exogenous sources of institutional quality, which were a result of historical development. The role of the House of Chiefs reflects the legitimacy that Botswana places on institutions present before the country became a republic. Although the House of Chiefs has no veto power in the legislature, according to an interview by Moroka Moreri, executive secretary of the Ntlo ya Dikgosi, it is still consulted and most decisions require consensus from the lower house. The House of Chiefs also acts as a liaison between the grassroots and top level officials in policy-making roles. With these sources of institutional quality, among others discussed in this dissertation, it is clear that the reason Botswana fares well is not because of the institutions themselves, but of the setting into which these institutions are immersed. Nigeria, Angola and the Democratic Republic of Congo have similar legal and regulatory frameworks as Botswana surrounding natural resources. However, they do not experience the same level of institutional success as does Botswana.

Similar to Botswana, Nigeria's federal government has managed its oil revenues, including their allocation, centrally since 1970. It has similar joint-ventures with multinational corporations that parallel the role of Debswana in Botswana, which also claim to invest in the country to develop corporate social responsibility agendas. Nigeria is a member of EITI. However, unlike Botswana which has one key partner in the diamond industry, Nigeria has a wide portfolio of institutions participating in the extractive industry sector of the country. Among these is a joint venture between the 
government with Shell, Agip, ExxonMobil and ChevronTexaco: the Nigerian National Petroleum Corporation (NNPC). The NNPC which administers subsidiary interests in oil exploration and production as well as marketing of oil and oil products. In addition, the Ministry of Petroleum regulates the oil industry; the Crude Oil Reconciliation Committee, performs the reconciliation of the various revenue streams held in public accounts and the Petroleum Products Sales Committee reconciles revenues received from refined petroleum product sales. The Federal Inland Revenue Service, the Central Bank of Nigeria and the Office of the Accountant-General of the Federation are also key in administering revenue collection (Bryon and Hofman, 2007). The central piece of legislation regulating the extractive industry in Nigeria is the Petroleum Act of 1969.

In contrast to Botswana, years of authoritarian rule in Nigeria under both civilian and military regimes undermined the development of an autonomous legislature. In the years following military rule, Nigeria's constitution extended the mandate of the National Assembly to establish committees, conduct investigations and approve the President's budget. NDI (2007) argues that both the senate and the house have committees keen on monitoring various extractive industry issues. These include budget, appropriations and public accounts committees to supervise budget creation and implementation. In 2001 an ad hoc committee was established by the House Speaker to facilitate the investigation of crude oil exportation and the importation of value-added products. It exposed inconsistencies that allegedly implicated prominent executive branch officials, uncovering the misuse of scholarship funds set aside to develop Nigeria's oil industry (ibid). 
Unlike in Botswana, Nigeria's legislature does not engage in dialogue with constituents or with the executive on extractive industry issues. Consequently, tensions between the executive and legislative branches erupt periodically. One such instance was when the anticipated NEITI bill delayed in the House of Representatives for over a year prior to passage by both houses. The Nigeria Extractive Industries Transparency Initiative (NEITI) was established to fortify extractive industry management and oversight but the bill was hindered by the legislature. According to former executive secretary of the NEITI Professor Assisi Asobie, the legislature itself was to be blamed for the corruption in Nigeria's oil and gas sectors ${ }^{44}$. Nigeria's legislators are widely believed to be dependent on the income generated from political connections, facilitated by their power and patronage networks. This perception has its carry-over from decades of scandal, fraud and corruption perpetrated by public officials and the persistent discontent over the lack of investigation and prosecution of offenders. This political culture of corruption and lack of trust in the country's institutions, is what this study argues are the reasons for Nigeria's failures in its extractive industry. In the case of Botswana however, corruption by both members of the legislature and key officials in the diamond industry is vehemently criticized. Former Debswana CEO Louis Nchindo and his cohorts Joseph Malope Matome, Garvas Nchindo and an unnamed Asian associate were arrested, charged and convicted of fraud and corruption ${ }^{45}$. Very little evidence of legislators taking part in corrupt practices was uncovered in this research.

\footnotetext{
${ }^{44}$ http://www.channelstv.com/home/2012/06/15/blame-the-legislature-for-corruption-in-oil-and-gasneiti-boss/

${ }^{45}$ http://www.sundaystandard.info/article.php?NewsID=9025\&GroupID=1
} 
Angola's legislative engagement with the natural resource sector is greatly undermined by laws of the country which reinforce executive control over all aspects of the country's oil and diamond industries. President Dos Santos is directly involved in negotiating concessions with multinational oil companies and NDI (2007) reports that substantial profits from the sector go unrecorded. His daughter, Isabel Dos Santos recently was crowned Africa's first female billionaire (Forbes, 2013), a feat hard to fathom without her father's access to the diamond and oil industry. Although it is given oversight over the extractive industry, Angola's legislature is highly partisan, with the ruling MPLA holding 129 seats, UNITA holding 70 seats and other parties having 16 seats. According to Reed (2009), Angola's National Assembly often prioritizes party loyalty above constituent interests and allegations that elected officials extract personal gain from oil and diamond revenue are rampant. As a result, the legislature itself is complicit in the mismanagement of the country's extractive resources, a situation that greatly undermines the legitimacy of the legislature by the Angolan people. As far as consensus-building is concerned, Angola falls short. According to the Bertelsmann Transformation Index (2010), in Angola there is ample reason to doubt that elected officials are genuinely invested in facilitating a healthy market economy and democracy in the country. Skepticism abounds with legislators from UNITA simply pressing for the reprisal of power and benefits, while those from MPLA exploit the discourse of democracy to acquire some degree of legitimacy and credibility. As a result, garnering public consent and approval for policy goals and agreement on concrete objectives has proven difficult in Angola. Although the country is a member of the Kimberly Process and has undertaken a series of reforms to improve public accountability in the diamond 
sector, these fall short of full disclosure. Bryon and Hofman (2007) state that Angola's government is protected by a law on state secrets, passed by the National Assembly in 2003. This law provides the legislature with broad powers to regulate the release and publication of information deemed damaging to national interests. Under this law, the government has the power to censor publications that expose proof of corruption.

Furthermore, confidentiality clauses are also common in Angola's oil contracts with only the president and a limited number of high-level cabinet ministers having full access to these agreements (ibid). This greatly undermines the legislation covering the oil industry (the Petroleum Act) and the mining legislation (Codigo Mineiro).

According to this dissertation, the context to Angola's failure in legislative oversight is due to its sources of institutional quality, and not the institution itself. The country's culture of corruption undermines the processes of development in the resource sector. The lack of legitimacy of the MPLA government by UNITA supporters makes consensus building daunting. Ethnic divisions emerging from the country's long civil war, created a divided state, and intervention during the Cold War of nuclear powers supporting opposing sides of the conflict, greatly exacerbated divisions, which are seen today in the country's legislature and beyond.

The DRC contains Africa's largest deposits of copper, cobalt and coltan as well as significant reserves of diamonds, gold and other minerals (Even-Zohar, 2007). This study finds that the country's history, including prolonged kleptocratic reign of Mobutu Sese Seko, two large-scale wars and rampant corruption in the country, is what disrupted the institutional foundation of the DRC and only through that context can the mismanagement of natural resources and the resultant experience of the resource curse 
be understood. The study finds that even if the DRC has the right formal institutions in place, it will be difficult for it to achieve sustained economic and political development because of the sources of institutional quality (or lack of quality).

The legal and regulatory framework of the DRC is similar to that of Botswana. It is directed by the Mining Code ratified by President Joseph Kabila in 2002. The Code was put in place to strengthen the regulation of the country's key industry and to establish guidelines for granting exploratory and appropriative licenses. It provides a revenue sharing scheme for mining royalties that grants 60 percent to the central government, 25 percent to provinces and 15 percent to social service projects at the local level and also regulates the sale and transportation resources and provides guidelines for artisanal mining. The ultimate responsibility for overall policy formulation and implementation is on the Minister of Mines. In addition, the Ministry Registry was established to enforce the Code's regulations and carry out administrative functions, including processing, reissuing and cancellation of mining exploration permits. An area tax (taxe de superficie) and an administrative fee (droit superficiarie) are also imposed to increase transparency in mining concessions. The Sercice d' Assistance et d'Encadrement du Small Scale Mining (SAESS_CAM) provides small scale artisanal miners technical support (McGuireWoods, 2013).

The DRC is currently under the regime of the Constitution of the Third Republic after being in interregnum between two constitutions for three years (2003-06) (AfDB/OECD, 2006). The current constitution institutes a regionalized semi-presidential republic, which exercises a separation of powers between the three government branches, as well as an allocation of prerogatives between the central government and the 
provinces. The current legislature's oversight of the DRC took over the monitoring and surveillance of the extractive industry of the country from the transitional legislature of the interregnum which was appointed rather than elected. The transitional legislature's requests to the executive for funds to conduct legislative oversight over the mining sector were largely ignored or denied. Occasionally they submitted questions to or summoned ministers to address issues of corruption and mismanagement of state-owned enterprises, resulting in the calls for suspension of several ministers. According to Dinka (2006) a trail of tainted minerals has been well-documented in the DRC's recent wars as belligerents in both sides of the conflict obtained supplies and military hardware in exchange for smuggled resources. To address this issue, the transitional legislature created the Lutundula Commission headed by Congolese lawmaker Christophe Lutundula, consisting of legislators representing the traditional pre-war opposition parties, government, and civil society. The commision's goal was to gather inventory of all deals signed during the two wars, analyze the terms of these agreements and their financial impact, recommend validation, amendment or cancellation of each deal and recommend payment to the government or its nationals for any loses suffered as a result of any stated contracts (Dinka, 2006). However it experienced failure due to the lack of full cooperation from the country's former belligerent factions hampering its ability to investigate a number of cases due to ongoing instability in parts of the country. By the time the legislative elections were held, the Lutundula Commission's report had not been deliberated by the legislature. The elected legislature of the third republic provided for a two chamber legislature consisting of a National Assembly elected by direct universal suffrage and a senate whose members were elected by provincial assemblies. It was 
parliament's duty to determine government policies including public finance, property taxes and the exploitation of natural resources. However, due to pertinent issues surrounding the country's institutional environment, the revisiting of the Lutundula Commission's findings which would facilitate more robust legislative oversight in the mineral sector of the country, has proven difficult (NDI, 2007).

As the findings of this dissertation projects, due to the DRC's violent past, the foundations for the adoption of new institutions under the third republic will be very difficult. According to Dinka (2006) the country faces daunting logistical and communication constraints across the country making citizens unaware of developments beyond Kinshasa. The current institutions were built on a shaky foundation, with current contracts in the mining sector having been signed prior to the implementation of the mining code by persons sometimes not authorized to do so (NDI, 2007).

As is illuminated in the experiences of Nigeria, Angola and the Democratic Republic of Congo, it is neither the institution managing the oil or mineral resource sector, nor the institution that monitors or provides oversight of the natural resource sector that determines whether a country will escape the resource curse. Nigeria, Angola and the DRC all have joint ventures similar to the one that manages Botswana's diamonds. In addition, the legal and regulatory frameworks of all four countries are similar. The key differences lie in the sources of institutional quality in each country. Botswana's the tradition of openness, dialogue and transparency which is grounded in regular consultations between the legislature and the diamond industry, between the upper and lower houses of the National Assembly and between the leaders and citizens at the local level greatly complemented the country's institutional quality and distinguishes 
itself from other resource-rich countries in the region. Through the government's requirements for equity participation and board representation in the mining sector, Botswana serves as an example of how to organize the extractive industry. It provides a model for a lucrative partnership between government and the international mining multinational. As a result, since independence the country has built a reputation as a model of good governance and economic progress. This is unlike the countries of Nigeria Angola and the DRC whose political foundations were set with values not compatible with sustained political and economic development. Table 6.1 revisits the key historical foundations of all four countries. 
Table 6.1: Summary of Key Variables in Explaining Variations in Institutional Quality

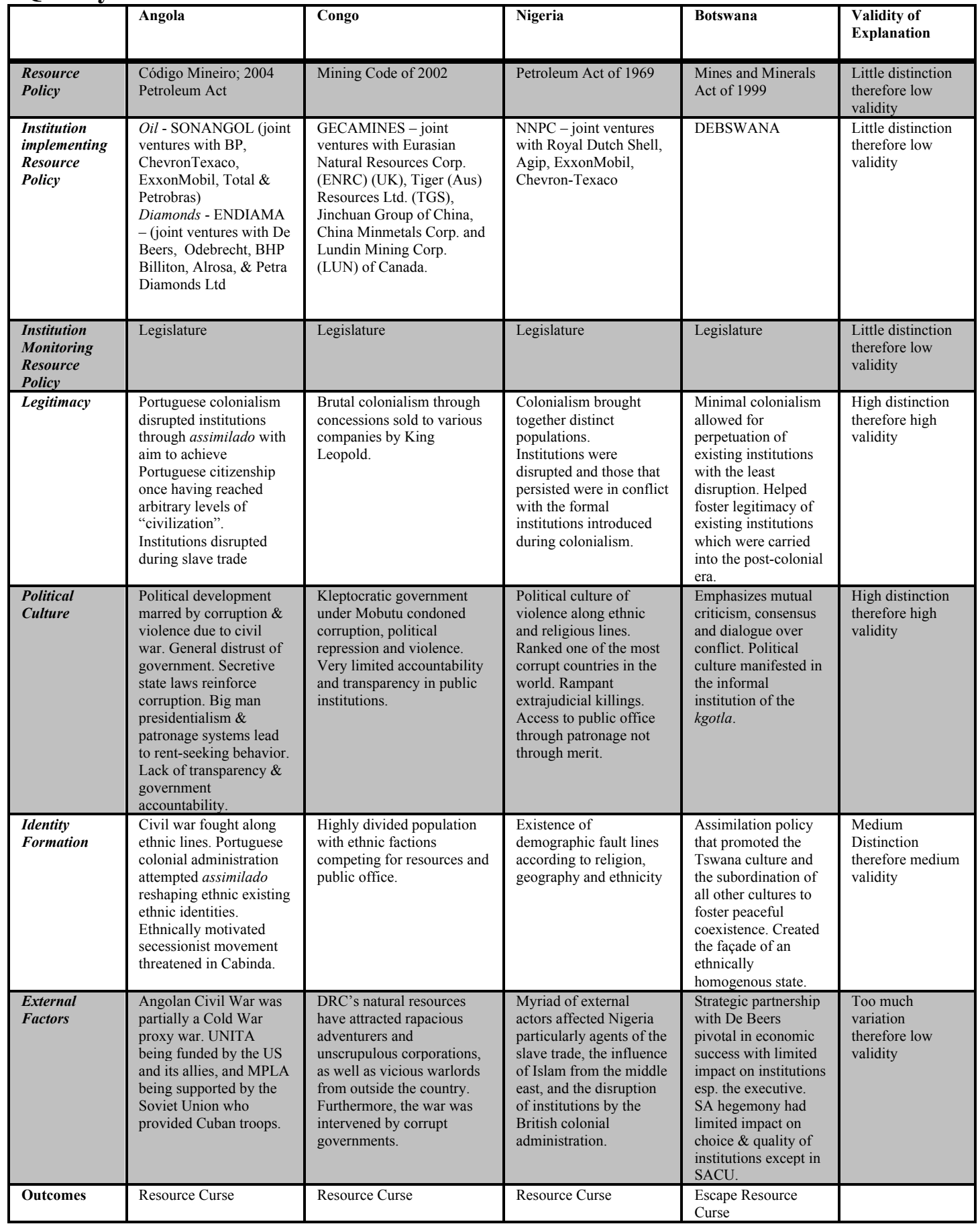

Source: Own 
The summary of findings in Table 6.1 puts into perspective Botswana's success vis a vis the natural resource sector, when compared to the resource-curse countries of sub-Saharan Africa. The legal and regulatory frameworks of the extractive industries of these countries claim to provide the same powers of oversight and intervention to the legislature. However, the experiences of each country were determined, not by the formal institutions supporting the natural resource sector, but the sources of institutional quality. As depicted in table 6.1, Angola, Nigeria and the DRC all experienced colonial disruption to existing institutions, all have corrupt and violent political cultures, all have problems of ethnic heterogeneity and all have had external actors disrupting their internal institutions. Botswana to a great extent escaped these sources of institutional disruption which compromise the quality of institutions and provide the foundation for bad governance.

\section{Evaluating Variables Contributing to Institutional Quality}

Although not completely mutually exclusive, it is the view of this study that some of the four variables offer more explanatory value in understanding the Botswana anomaly. As such, this chapter attempts to analyze the strength of each variable in contributing to Botswana's institutional quality. As defined in Chapter 2, institutions are "humanly devised constraints that structure political, economic and social interaction" (North, 1991:97). Thus, institutional quality reflects the effectiveness of that constraint, whether it is through a formal (constitutions, laws and property rights) or informal (e.g. taboos, sanctions, customs, traditions and codes of conduct) institutions. 
Whether institutions function in keeping with their stated purposes depends on the setting into which they are inserted into and evolve in. According to Wagener (2011), whether entrepreneurship develops and in which direction, depends on its environment and the institutional structure of the particular society. This is due to the fact that institutions determine the pay-off of individual activity, since everyone is striving for the highest pay-off. Where profits are highest due to rent-seeking, piracy or corruption, these are the activities that most individuals and entrepreneurs will gravitate towards. However, where transparency and accountability provide the highest profits, good institutions prevail and constrain predatory economic behaviors.

According to North (1991), effective institutions raise the benefits of cooperative solutions or the costs of defection. They reduce transaction and production costs per exchange, so that potential gains are realizable. This dissertation describes institutional quality as institutions that reflect characteristics of good governance. These eight characteristics are transparency, accountability, responsiveness, equitability and inclusiveness, effectiveness and efficiency, pursuit of the rule of law, participatory practices and consensus (UNESCAP, 2013). Such an analysis is necessary to judge strong versus weak explanations of the same proposition, and it would also clarify the meaning of comparative explanatory judgments (Schupbach and Sprenger, 2010). This is done in order to offer lens through which the Botswana case can be understood.

This dissertation first attempted to determine the sources of institutional quality in Botswana utilizing data collected from both primary and secondary sources, from key informant interviews and from Afrobarometer surveys. Key informant analysis on 
adherence to rule of law, legitimacy of authority, characterization of political culture, impact of ethnicity and identity management, and the role of external actors were measured to weigh their contribution to institutional quality. Furthermore, the beliefs of citizens on whether the country is being governed according to the will of the people, as well as their trust in the system using Afrobarometer data, gaged the utility of each variable in the study. In determining the relative weight of each factor/ variable, this dissertation looked at the evidence to determine where the weight of the evidence lay. Where there is not sufficient evidence, no argument can be made.

The second guideline that will be used to evaluate the variables is whether the hypothesized source of institutional quality primarily affected formal institutions or informal institutions. It is judged, following Siedler (2011)'s hierarchy of institutions, that informal institutions will have a greater role in contributing to the robustness of Botswana's institutions. Siedler (see in Table 2.1) argued that, as opposed to formal institutions which at most define the institutional framework, informal institutions define the way a society conducts itself. This dissertation argues that the effectiveness of constraints i.e., institutions, depends equally on the principles that inform them, as well as the mechanism of their enforcement (Wagener, 2011). The constraints of formal institutions are primarily the responsibility of the state, as the state has monopoly over the legal use of force. As a result, states can produce either bad or good institutions. A state can foster corruption, big man presidentialism and clientelism (Bratton, 2007) or it can foster participatory democracy, the rule of law, transparency and accountability (UNESCAP, 2013). Informal constraints are more difficult to ascertain. However, 
according to $\mathrm{Yu}$ (2007), cooperation and the preservation of social order are selfenforcing aspects of informal institutions. They serve to maintain social stability and prevent opportunistic behaviors (ibid). They are very persistent (Siedler, 2011). According to De Soysa (2006), informal institutions are determined to have quality, based on outcomes such as their conflict resolution mechanisms, effective property rights, information exchange and general social trust. Thus, in this dissertation, the extent to which each variable contributed to the factors that reflect good governance i.e. accountability, transparency, effectiveness and efficiency, participation, rule of law, equitability and inclusiveness, responsiveness and consensus, will reflect the extent of its contribution to institutional quality in Botswana.

The third consideration in evaluating this dissertation's hypotheses is whether the variable is external or internal to the state. Although external sources of institutional quality can be very important, they have been very difficult to internalize. As a result, those explanations that derive from within the state provide more utility in explaining institutional quality. Furthermore, when addressing the international context, it is assumed that the external effect should be experienced by other states alike and therefore, if they are to be the causes, the effects should be the same across countries. Internal (i.e. endogenous sources of institutional quality), are believed to co-evolve with the institutions in question. This co-evolution allows for an intricate correlation between cause and effect over long periods of time, that external (i.e. exogenous variables) cannot.

Fourth, when evaluating the hypotheses, a determination of how spontaneously the given source of institutional quality resulted in the observed end point was made. Was 
the outcome a result of deliberate action or spontaneous evolution? Was the outcome intended ex ante? The intentionality of the outcome is very important in determining the sources of institutional quality. Countries with bad institutions do not set out to have bad institutions; their constitutions do not sanction corruption and they usually have legislation that condemns it. They have constitutions and laws that reflect the desire for democracy; however, the practice of democracy eludes most of these (developing, resource-rich) countries. Thus, the nature of the formal institutions and the intentions of their creators tell us little about the quality of how institutions function in practice. Instead, it is the effects that result from spontaneity that help us understand more whence institutional quality emanates. Most persisted forms of institutions, particularly informal institutions, are the results of accidents and unintended results of historical development. Informal institutions are usually more organic and evolutionary because their development is usually not intended ex ante. As a result they can emerge spontaneously and endure for generations. It is assumed that path-dependence and incrementalism of formal institutions sometimes prevent the implementation of the most efficient institutional regime. The deliberate choice criterion stems from Adam Ferguson's idea that "nations stumble upon establishments, which are indeed the result of human action, but not the execution of any human design" (Wagener, 2011:184).

Lastly, the variables will be evaluated according to which helped nurture the principles of good governance listed in Figure 2.1 (page 48). The explanations that provide more detail into how transparency, accountability, rule of law, consensus, effectiveness and efficiency, responsiveness, equitability and inclusiveness as well as 
participation emerged are given more weight. As a result, not only is the context of the variable under question a determination of institutional quality, but also the content of the variable.

The following sections will evaluate each variable in turn; beginning with the one that offers the least support of institutional quality, to the one the study finds the most evidence. As a result, the discussions will not follow the chronology of analysis observed in the preceding chapters.

\section{The "Exogenous" Context}

The hypothesis that exogenous sources of institutional quality helped facilitate Botswana's escape of the resource curse was considered in this dissertation primarily because Botswana's autonomy came into question within the context of its geopolitical situation during the period in question. Prior to colonialism, Botswana was of strategic importance to the British as a way to "check" German realpolitik in southern Africa and limit its aspirations to colonize Bechuanaland along with Southwest Africa, a situation eventually avoided by the British. Although the British did not find any material interest in Botswana, they colonized the land with a minimal budget. This led to a partnership between the British and Tswana chiefs, who spontaneously requested protection from the British in the aftermath of a Boer attack. Colonial Bechuanaland was constantly under threat of incorporation into the Union of South Africa, and it was later a member of SACU, a regional customs unions controlled by South Africa. In post-colonial Botswana, the country established a key partnership with De Beers, upon the discovery of two of the 
largest diamond mines in the world in 1967. This discovery heralded the beginning of a lucrative partnership that would see Botswana become one of the richest countries in subSaharan Africa. It is with this backdrop that Botswana's post-colonial development trajectory was hypothesized to have emerged from these exogenous factors. However, this dissertation found the least evidence supporting the assertion that exogenous factors determined institutional quality in Botswana.

The evidence presented in this dissertation illustrates that, for the most part, external influences were never fully internalized in Botswana. In the case of British colonialism, it is difficult to assess its impact on institutional quality in Botswana because its nature was one of benign neglect, and thus played more of a passive role in determining what is observed as institutional quality in Botswana today. In fact the British were very passive participants allowing for the greater part the continuity of Botswana's pre-colonial institutions permeating into the post-colonial state. This inadvertently supports a separate hypothesis in this dissertation that will be addressed in a subsequent section of this chapter.

As for the influence of South Africa, the only Botswana institutions affected were the institutions of trade. Despite apartheid South Africa exerting pressure on Botswana, the country remained largely autonomous to its influence. One key argument in characterizing the South Africa-Botswana relationship has been one of semi-dependency, particularly in the area of trade. However, Botswana's autonomy is demonstrated by the fact that it achieved growth rates far outstripping South Africa's. Botswana currently has a higher per capita income, as well as better development indicators than does South 
Africa, an explanation which arguably lies in the fact that the country chose to engage South Africa on its own terms. This fact alone greatly undermines the idea that South Africa played a pivotal role in shaping Botswana's economic and political institutions. Furthermore, Botswana's autonomy extended to the rest of the continent of Africa, even while the entire continent was calling for sanctions against apartheid South Africa, Botswana stood firm against the pressure and decided to continue trading with South Africa. But this course of action was not due to pressure from South Africa, but due to the calculation of Botswana authorities that this policy was in the country's interest. This fact alone shows how strong Botswana was in determining and defining its own interests, and implementing policies in pursuit of them.

In the case of De Beers, the company greatly influenced the diamond -led economy in Botswana and was one key to the development of Botswana's economy. The half century co-operation between De Beers and the Botswana government is a publicprivate partnership culminated with the establishment of Debswana. The collaboration began only three years following independence from the British, in a country that was widely seen as poor and limited in future prospects. Today, Botswana is the largest producer of diamonds by value in the world and has emerged as a middle-income country with commendable achievements in economic growth, infrastructure and human development. Furthermore, De Beers has been greatly influential in Botswana's political stability through its close relationship with the Botswana Democratic Party and its adherents, a situation that has inadvertently enhanced the country's political predictability and hence its attractiveness as an investment destination. Yet when compared with other 
countries, like Namibia, that have parallel public-private partnerships with De Beers (i.e., NamDeb), but much lower economic and political performance indicators than Botswana, the exact influence of this company in determining institutional quality comes into question.

Overall, this dissertation argues that although exogenous factors contributed to some of the observed indicators of economic and political development in Botswana, they were neither responsible for, nor disruptive of, Botswana's institutional quality.

\section{Endogenous Sources of Institutional Quality in Botswana}

\section{Ethnicity and Identity Management in Botswana}

The hypothesis that ethnicity and identity management contributed to Botswana's institutional quality emerged from a widespread set of literature citing ethnic heterogeneity as the bane of African economic and political development. Inspired by the central work of Easterly and Levine (1997), the hypothesis identified ethnic diversity, consolidated by the artificial drawing of colonial boundaries, as the greatest determinant of bad governance and low institutional quality in sub-Saharan Africa. This dissertation argued that because identities in Botswana were transformed and managed (i.e., "constructed,") through the pre-colonial, colonial and post-colonial period, they provided the foundations of peaceful coexistence, thus strengthening institutional quality. The extent to which the country is viewed today as "homogenous", linguistically at least, is a reality deliberately created by colonial and post-colonial authorities. 
Botswana's assimilation project immensely reduced what Caselli and Coleman (2006) refer to as "ethnic distance" in Botswana's society. Low ethnic distance connotes an increased degree of understanding and intimacy between members of different identity groups, which is manifested in the readiness to establish more or less close social relationships with members of the group. The key idea is that when groups are formulated along ethnic lines, ethnic identity becomes a marker to recognize potential infiltrators. Identity management, through assimilation, in Botswana provided a mechanism for group membership and inclusion, which was used to avoid discrimination of access to national wealth. As a result, to this day, Botswana is greatly viewed as largely homogenous society. The country is named after the Tswana people and the language Setswana is the national language, spoken by over 80 percent of the population.

The literature on ethnic conflict views natural resources as providing an incentive for agents to form groups to wrest control of resource assets from the rest of the population. The victorious group in a conflict allocates resources to ensure the exclusion of non-members because infiltration would result in less dividends being shared among the original group. However, this did not occur in Botswana. Early Botswana elites decided not to let access to natural resources be determined by ethnic heritage. Instead, they made assimilation to "Tswanadom" a criterion for such access. As long as minority groups adhered to the dictates of Tswana culture and linguistics, they could essentially gain access to all the privileges and rights accorded to Botswana citizenship. In the cases where specific groups opted out of Tswanadom, they inadvertently opted out of the privileges and rights enjoyed by the majority. Such was the case of the BaSarwa. 
In Botswana, most factors and conditions isolated by Blagojevic (2009) as contributing to ethnic conflict are largely absent. The country has very little evidence of structural crises in its history and there is a general absence of historical memories of inter-ethnic grievances. Institutional factors have actually promoted ethnic tolerance, and the manipulation of historical memories by political entrepreneurs was utilized to evoke unity and peaceful coexistence, as opposed to negative emotions such as fear, resentment and hate toward the "other". As a result, the evidence reflects that the Botswana case generally supports the hypothesis that ethnic homogeneity contributed to development in Botswana and contributed to the non-occurrence of ethnic conflict observed. One has to recognize that this homogeneity is far from natural or "primordial," and in fact has resulted from the assimilation policy. Yet it is also true that Botswana's ethnic demographics permitted this policy to be pursued in a way that could not easily have been pursued elsewhere.

A key weakness of the argument that this variable provided institutional quality in Botswana, however, stems from the fact that the unifying identity in Botswana was not a product of spontaneous evolution in Botswana, as some adherents to the primordialist approach to ethnicity might suppose. The primodialist approach, which accounts for the role of emotions and the conflict potential of ethnicity, argues that the existence of ancient differences among ethnic and cultural groups, and the urge to "fear" and reject the "other" is natural and primal, dating back to human's remotest ancestors and their animal predecessors. It argues that tendencies toward xenophobia and intolerance are natural to human societies, and has been a dominant approach in explaining ethnic 
conflict. Upon investigating the variable of ethnicity and identity management in Botswana, it becomes apparent that Botswana's "ethnic homogeneity" is not primordial. Instead, it is the product of an assimilation project implemented by nationalist Tswana elites in the few years following independence. This identity was institutionalized as the national identity. As a result, due to its path-dependence, the assimilationist project in Botswana raises more questions than it actually offers answers for the Botswana case and beyond. Why were subordinate groups in Botswana willing to adapt to Tswanadom at the expense of their own cultural and ethnic heritages? Furthermore, why did other countries with ethnic diversity not have the same success in pursuing assimilation policies? If the policy of assimilation is all that countries need to put in place, wouldn't they already have done that by now? In fact this observation raises deeper questions. Why was the assimilation policy effective in Botswana? Why was there no violent resistance to the subordination of cultures in Botswana? The fact that these questions give weight to other variables, weaken the particular hypothesis that Botswana obtained its institutional quality from ethnic identity management. Instead, it argues that variables that resulted due to evolutionary processes of longue durée provide better explanations and understanding of the Botswana case.

\section{Legitimacy and Historical Continuity in Botswana}

The evidence gathered by this dissertation strongly suggests that institutional quality in Botswana was not the result of any discrete policy decisions. Instead, it was the result of an evolutionary process of longue durée. This is observable in the legitimacy of 
authority in Botswana facilitated by historical continuity. Imported institutions across most of the remainder of Africa conflicted with existing institutions, and hence had low levels of legitimacy. The success of Botswana, however, reflects high legitimacy of functional and democratic institutions because they were heavily embedded in the historical traditions of the state.

This study adopted a Weberian understanding of 'legitimacy' in that its conceptualization depended not so much on the behavior of leaders or the design of institutions, but on how these were evaluated by those whom the leaders and institutions claimed to govern. Weber isolated three bases for legitimate authority. Rational legitimacy, resting on a belief in the legality of rule and of those put into power under those rules to issue directions; traditional legitimacy, resting on the acceptance of the sanctity of immemorial traditions and the legitimacy of those exercising authority under them; and charismatic legitimacy, resting on the dedication to the unique sanctity, heroism, or exemplary character of an individual person or group and the normative forms of orders ordained by them (Novak (2005:6). This dissertation found aspects of all three forms of legitimacy contributed to Botswana's institutional quality.

Legitimacy in Botswana on traditional grounds was facilitated by historical continuity. Unlike most other African countries which were crown colonies or settler colonies, Botswana was merely a protectorate of the British Empire. This enabled traditional authority in Botswana to thrive and, as a result, contemporary Tswana society sees a high level of continuity between its pre-colonial, colonial, and post-colonial institutions. Charismatic legitimacy emerged from Seretse Khama’s leadership, 
particularly at a pivotal point in resource development. Khama gained legitimacy, first, from his biological link to the traditional governance structures of Botswana, which gave him credibility especially among his rural electorate. This organic link to the population gave him credibility, as well as fostered a personal commitment to the economic growth of his country, facilitated by his inherent chiefly duty as custodian of resources and designator of responsibilities. These circumstances led to the pre-existing Tswana hegemony within the new structures of post-colonial statehood. Legitimacy, this time on rational grounds, was reinforced at independence whereby the adoption of a parliamentary system of democratic governance and the adoption of a constitution followed newly adopted formal institutions. Furthermore, the succession of Quett Masire, a commoner, into the rank of president, further consolidated the legitimacy of the newly adopted formal institutions. These new institutions were based on principles that greatly reflected Botswana's traditional culture.

In relation to the territorial state, generally regarded as the ideal form of state, legitimacy in Botswana enabled agents of the central state to achieve the voluntary cooperation and compliance of individual citizens and non-state actors without a reliance on coercion or surveillance. This was possible since most citizens regarded the agents as appropriate to having the rights and responsibilities surrounding the making and implementation of laws, policies and programs on their behalf-regardless of the shortterm performance or popularity of specific programs or leaders. In comparative perspective, African states are generally viewed as illegitimate, since their very existence results from colonization from alien Europeans; they had human settlement before 
colonization that was not reduced to insignificance or assimilated under colonialism; they did not re-create a pre-colonial sovereignty through gaining independence; and after independence, they did severe violence to existing institutions. The foundations of political authority in independent African states bore little resemblance to those in precolonial societies and rarely did the colonial state bear any relation to the economic systems, political organizations, and networks of social identification of the indigenous people. As a result, in the case of Botswana, the variable of legitimacy and historical continuity bears a considerable weight.

Legitimacy and historical institutional continuity provide a substantial context to understanding Botswana's escape of the resource curse. Most of the evidence collected and analyzed point to the role of continuity of institutions as a key determinant of postcolonial success. Emerging from within the state, legitimacy provides an endogenous force contributing to institutional quality that evolved over decades and therefore is not a result of deliberate action, but of organic evolution. However, legitimacy provides no moral judgment to the institutions that were passed on and whose continuity they facilitated. For, in essence, Weberian legitimacy bears no moral significance or relativity to the institutions it legitimizes.

In other words, the content of what was passed on over the three key periods of Botswana's history, which led to the observed institutional quality, is not explained by the legitimacy hypothesis. In comparative perspective, countries like Ethiopia that were never colonized still have enduring institutions that were never disrupted, but these do not provide a good explanation for why their institutions are not as robust as Botswana's. 
Instead, the greatest explanation for Botswana's institutional quality can be found through understanding its history using its political culture as the main variable.

\section{Political Culture and Institutional Quality in Botswana}

The evidence gathered in this dissertation greatly supports the idea that it was a political culture, evolved over centuries that provided the deepest foundation of contemporary democracy and institutional quality in Botswana. As will be described, political culture in Botswana is a factor endogenous to the society and state and one that resulted from spontaneous evolution. Botswana's political culture is the key to understanding both formal and informal institutional quality in the country. It provides both the context and the content of economic and political development, particularly as it is the only explanation that mirrors many of the eight principles of good governance, among which are participation, consensus and the rule of law. More importantly, evidence uncovered through both primary and secondary sources of data, insights from key informant interviews, and Afrobarometer survey data provide a wealth of evidence supporting this claim.

Political culture helps one understand Botswana's institutional success and its escape from all three resource curses. Botswana did not experience the resource curse of violence, because it was not its political culture to do so. The country has no history of being a crusader society as were the Zulus of modern day neighboring South Africa, and violence and conflict have never been condoned by traditional Tswana culture. It espoused a culture of mutual criticism and dialogue instead of violence, facilitated by a 
culture of consensus-building. As a result, Botswana also escaped the resource curse of authoritarianism, because its traditional political culture supports broadly democratic practices, beliefs and ideals. This political culture, which set the foundations of the kgotla, placed constraints on those in authority by holding them accountable. Finally, Botswana escaped the resource curse of underdevelopment, because its elite political culture of pragmatism enabled it to select the best possible courses of action that reflected its interests, whether it was through negotiating lucrative deals with the diamond multinational De Beers, or whether it was though withholding its participation from imposing sanctions on South Africa, its greatest trade and economic partner, despite continental pressure to do so. Pragmatism and rationality were revered above selfinterest, providing the foundation for functional institutions. Systems of corruption are generally not supported in Botswana and the beef-industry based elites avoid predatory practices in the profitable diamond industry, something which is atypical of elites in resource exporting countries, which tend to be rentier in character.

This dissertation found most evidence of the crucial stage of evolution of Botswana's political culture in its pre-colonial period. The underpinnings of Botswana's political culture are found in the kgotla. The kgotla affords a model for serious and candid consultation among equals, which informs the patterns of interaction. It embodies basic values of sociability, respect and inclusiveness, with proceedings ranging from those of social significance and the adjudication of individual misdemeanors, to those of political significance, such as the bureaucratic division of labor (Young 2003:211). The kgotla has thus set the standard for highly functional social interaction that is 
immediately emulated whenever the diffusion of information, the need to arrive at a decision, or the settlement of a conflict, is pertinent. The kgotla addresses a breadth of contexts, and as such is the hallmark of Botswana's national political culture. Hence, for Botswana citizens, "the test of appropriate public behavior, decision-making and democracy thus lie in principle in the [kgotla type] of practical consultation" (Young, 2003:211). Although the kgotla has not been historically a democratic institution, the basic principles that it espouses are democratic values. Hence, the adoption of a democratic republic upon independence held democratic expectations that were already part of the belief systems of Batswana. Furthermore, although the two systems evolved asynchronously, they emerged in the post-colonial setting, providing legitimacy and support to the new imported system.

In the post-colonial era, most evidence is skewed towards the role of the political culture of Botswana's elite, who institutionalized the democratic formal institutions, adopting pre-colonial political culture. As is predicted by North (1990), the perception of feasible alternatives in Botswana was greatly governed by the belief system of the players, which acted as filters to the information from experience. The statement by North (2005:59) that "the structure of an economic market reflects the beliefs of those in a position to make the rules of the game," clearly reflects this experience. The influence of elite political culture in Botswana has persisted. They have helped frame important institutions, and have been supported by the belief of others that they will stay in power makes these institutions work. The grand coalition of Botswana's elite, incorporated both traditional and modern elites, public and private elites, rural and urban, hosting 
consultative forums to foster participation of all decision-making stakeholders. This provided the foundation of equitability among interested parties.

The content of Botswana's political culture is just as pivotal as its context. The country has maintained a reputation for accountability and transparency, formalized through the constitution and supporting legislation which calls for open government. Despite the BDP remaining in power since 1966, the foremost political opposition party, the BNF, competes for seats in parliament freely. Furthermore, their ability to influence public debate has never been curtailed. The BDP's tolerance is grounded in consensual agreement among the electorate, whose traditions include limiting the power of traditional leaders and holding local consultative assemblies, thus offering a basis for accountability and consensus within the party. Individual presidents have fused this tradition into their individual leadership styles, insisting on curbing corruption, despite the incentives for corruption postured by Botswana's strong diamond mining.

Due to a culture of accountability, the government of Botswana has been responsive to the needs of the country's population, particularly via the regularity of competitive elections. This is as a result of the need to maintain political support, particularly of the BDP. The BDP's public sector policies, e.g. social services and physical infrastructure, have been made available to both rural and urban populations and to members of most ethnic groups, those that have "assimilated". Furthermore using diamond revenue, the government, in partnership with De Beers, has put in place various AIDS programs aimed at addressing the country's epidemic.

To ensure the rule of law, Botswana has been conscious to ensure the independence of its judiciary. This has even left some decisions of the judiciary that are 
unfavorable to the government. Individuals are free to challenge the constitutionality of citizenship laws as was the case of Unity Dow, an immigrant to Botswana. She alleged discrimination against her children who although born in Botswana, were not automatically granted citizenship. She won the case (Hoffman, 2003). Furthermore, within the diamond sector, the rule of law is exercised through the serious criminalization of diamond carrying by Botswana citizens and is under the jurisdiction of the Diamond and Narcotics Unit of the Botswana Police. The current sentence for the illegal carrying of diamonds by individuals is a minimum of five years and a maximum of fifteen years in prison. The corruption trials of Debswana director Louis Nchindo is also case in point, illustrating that in Botswana no one is above the law. These aspects of Botswana's political culture greatly enhance the country's institutional quality.

Afrobarometer data analyzed on Botswana, shows that the mass political culture of the country greatly support the institutions that are in place, thus facilitating the quality of those same institutions. Botswana citizens champion competitive democratic elections and disparage a whole spectrum of other forms of governance. They generally are not tolerant of corruption and do not condone systematic violence. The observation of citizen apathy in elections, however, is buffered by the elite political culture, which generally protects both those who participate and those who do not equally.

The Botswana case readily underscores ideas of how political culture can enhance institutional quality. Despite having similar legislative oversight and monitoring frameworks in the extractive industries, and despite having similar incentives and similar resources, Nigeria, Angola and Congo did not have the same fortunate outcome as Botswana. This illuminates two areas of further research in the resource curse equation. 
Scholars interested in the resource curse phenomenon, should play closer attention to endogenous sources of institutional quality like political culture and legitimacy of authority and of institutions into the countries they are covering, as these will illuminate the setting into which all planning, decision- making, implementation and monitoring of both resource-specific issues, and the decisions surrounding developmental management in resource-rich countries, are made. The implications of this research also project beyond the resource-curse issue in particular, and can be used to understand failures in other sectors of the economy beyond the extractive industry.

\section{CONCLUSION}

The argument for political culture (and to a great extent legitimacy) in evaluating Botswana's sources of institutional quality provides the greatest understanding of Botswana's escape of the resource curse. It shows how political culture in Botswana which was compatible with the principles of democracy and development, is what in essence provided robustness to Botswana institutions, enabling good governance and quality institutions in the country. The evidence shows that although institutional quality was aided by the historical continuity of its institutions, the legitimacy of those in authority, the management of the country's identity and the partnerships with external actors, it was the political culture that provided the foundation for all these variables to bring about Botswana's successful.

Although this conclusion is found to be the most convincing, it is however a pessimistic view of the fate of non-renewable natural resource exporting countries. If this conclusion is correct, the deepest sources of Botswana's institutional viability are to be 
found, not in active policy decisions and choices, but in variables that persist for centuries and that are evolutionary and spontaneous rather than deliberate. As a result, it provides very little counsel to other countries that are resource cursed and highly dependent on extractive industries. To change a culture is a very daunting task, which involves the learning of new customs and the unlearning of old rules. However, this conclusion emphasizes the role of education among the populations of resource exporting countries, as with education comes the hope of the changing of attitudes, beliefs and customs that could facilitate institutional quality.

This study concludes by encouraging scholars of the resource curse to look beyond the institutional and economic explanations of escaping the resource curse, and to look instead into the sources of resource-rich countries' institutional quality such as political culture and legitimacy, as these may provide more insight and explanatory value into whether a country will suffer from or ultimately escape the resource curse.

\section{EPILOGUE: FURTHER RESEARCH}

The conclusions arrived at in this study have illuminated the role that political culture (and legitimacy) can play in determining institutional success or failure in a country. For an even deeper understand of why Botswana's institutions succeed, the linkage established in this dissertation could be explored further by examining other specific institutions in Botswana. For instance, one institution of interest is the Botswana military. According to Masire (2007), the Botswana Defense Forces focusses on antipoaching activities, disaster-preparedness and response, support to civil operations, and 
assistance in foreign peacekeeping missions. This is counter to the activities of armies of other resource-rich countries like Angola and Nigeria, which spend billions for weapons and military equipment from China, Russia, Ukraine, and Israel. According to the Guardian (April 26, 2012), in 2011, the Botswana military spent only US\$371 million on arms, as compared to Angola which spent US\$3,647 billion and Nigeria which spent US $\$ 2,410$ billion (ibid). As the resource curse literature alleges, revenues from the export of non-renewable natural resources are frequently used to keep the armed forces well equipped in order to ensure political regime security. Botswana's military has, however, not been intrusive into the country's political institutions, despite the current president Ian Khama being a former commander of the Botswana Defense Forces. Furthermore, it has not been directly affected by the flow of natural resources in a way that is destructive. The question as to why the Botswana military has not partaken in similar behaviors as other resource-rich countries is possible focus for further research illuminating the functionality of Botswana's institutions.

Also worthy of further research are the caveats issued on Botswana's escape of the resource curse. The plight of the BaSarwa, the HIV/AIDS epidemic that plagues the country, and high unemployment rates, all seem to call into question the rosiness of the Botswana experience. Botswana has a very high level of inequality as is evidenced by its high Gini coefficient ${ }^{46}$ of 0.63 . The BaSarwa experience is the epitome of this inequality, with most members of this identity group living well below the poverty line, suffering

\footnotetext{
${ }^{46}$ The Gini coefficient is a measure of statistical dispersion representing the income distribution of a nation's residents. It measures the inequality among values of a frequency distribution (for example levels of income). A Gini coefficient of zero expresses perfect equality, where all values are the same (for example, where everyone has an exactly equal income). A Gini coefficient of 1.0 (or 100\%) expresses maximal inequality among values (for example where only one person has all the income).
} 
malnutrition, loss of land, poor education, and marginalization from access to most other benefits that Botswana's diamond wealth entails (Ditshwanelo, 2001). Furthermore, Botswana has one of the highest adult incidences of HIV/AIDS in the world with the World Health Organization (2011) reporting a range of 25-30 percent of adults being HIV positive. In addition, according to the Africa Economic Outlook (2013), amongst other major challenges confronting the government are a national unemployment rate of 17.5 percent. These troubling statistics call into question whether Botswana's institutional effectiveness and success can be sustained in the future. They also remind us that even well-functioning political institutions productive of political stability and formal democracy do not create social justice for us. Further research should be done to address these paradoxes, as past research efforts have placed them at the periphery of their analyses. 


\section{REFERENCES}

Alayli, Mohammed Ali (2005) Resource Rich Countries and Weak Institutions: The Resource Curse Effect, Berkeley, CA: University of California,

Acemoglu, D., Johnson, S. and Robinson, J. A. (2002) "An African Success: Botswana", in Rodrik, D ed (2002) Analytic Development Narratives, Princeton: Princeton University Press.

Acemoglu, Daron, Johnson, Simon and Robinson, James A (2001), “The Colonial Origins of Comparative Development: An Empirical Investigation", American Economic Review, 91, December 2001, pp. 1369-1401

Alden, Chris and Soko, Mills (2005) "South Africa's Economic Relations with Africa: Hegemony and its Discontents", The Journal of Modern African Studies, pp 367392, Cambridge, UK: Cambridge University Press.

Alesina, A. and. Drazen A (1991), “Why are Stabilizations Delayed?” American Economic Review 81, 1170-1188.

Andersson, Lars-Gunnar and Janson, Tore (1997) Languages in Botswana: Language Ecology in Southern Africa, Gaborone, Botswana: Longman,

Banerjjee, Abhijit and Iyer, Lakshmi (2002) '”History, Institutions and Economic Performance: The Legacy of Colonial Land Tenure Systems in India", Massachusetts Institute of Technology, Department of Economics, Working Paper Series

Basdevant, Olivier, Benicio, Dalmacio, and Yakhshilikov, Yorbol (2012) "Inequalities and Growth in the Southern African Customs Union (SACU) Region"; IMF Working Paper African Department and Research Department, Washington DC:IMF

Baumann, Timothy (2004) "Defining Ethnicity", The SAA Archeological Record

Beaulier, Scott A. (2003) 'Explaining Botswana's Success: The Critical Role of Postcolonial Policy, Cato Journal, Vol. 23, No. 2, pp. 227-40

Bennett, Bruce 2002. "Some Historical Background on Minorities in Botswana". In Mazonde, Isaac (2002) (ed.). Minorities in the Millennium: Perspectives from Botswana .Gaborone: Light Books.

Berreman, Gerald D. (1972) "Race, Cast, and Other Invidious Distinctions in Social Stratification" Race13:385-414

Blagojevic, Bojana (2009) "Causes of Ethnic Conflict: A Conceptual Framework”, 
Journal of Global Change and Governance. Volume III, Number 1 Winter 2009, Rutgers University

Booth, John A and Seligson, Mitchell, A (2009) The Legitimacy Puzzle in Latin America: Political Support and Democracy in Eight Nations, Cambridge University Press

Boschini, Anne, D., Petterson, Jan, and Roine, Jesper (2007) "Resource Curse or Not: A Question of Appropriability", Scandinavian Journal of Economics, 109(3) pp593-617, Malden, MA

Byrnes, Rita M. ed. (1996) “South Africa: A Country Study” Washington: GPO for the Library of Congress.

Carr, Craig L (2007) Polity: Political Culture and the Nature of Politics, Rowman and Littlefield Publishers Inc, Lanham, MD, USA

Caselli, Francesco and Coleman II1, Wilbur John (2011) "On the Theory of Ethnic Conflict”, London, England: London School of Economics \&Duke University

Chikwanha, Annie (2006) "Political Culture in the New South Africa", Seminar Report No 19. Konrad-Adenauer-Stiftung, Johannesburg, South Africa

Collier, Paul and Hoeffler, Anke (2004) "Greed and Grievance in Civil War." Oxford Economic Papers, 56(4), pp. 563-95

Collier, Paul and Hoeffler, Anne (2005) Resource Rents, Governance and Conflict, Journal of Conflict Resolution, Sage Publications, Inc.

Collier, Paul (2007) The Bottom Billion: Why the Poorest Countries are failing and What can be Done about it, New York, NY: Oxford University Press.

Crowder, Michael, Parson, Jack and Parsons, Neil (1990) Succession to High Office in Botswana: Three Case Studies, Ohio University Press

Curry, Robert L. (1987) “Botswana's Macroeconomic Management of Its MineralBased Growth: It Used Mining Revenues for Development and Services but Must Now Broaden the Beneficiaries", American Journal of Economics and Sociology, Inc

Dale, Richard (1995). Botswana's Search for Autonomy in Southern Africa: Contributions in Political Science, Number 358. Westport, CT: Greenwood Press

De Beers (2009) Annual Report to Society, De Beers Inc. 
De Beers (2010) “Living Up to Diamonds: Report to Society Full Report 2010”, De Beers Family of Companies

Denbow, James R and Thebe, Phenyo C (2006) Culture and Customs of Botswana, Greenwood Press, Westport, CT, London

Dunning, Thad (2005) "Resource Dependence, Economic Performance and Political Stability", Journal of Conflict Resolution, Sage Publications, Inc,

Dye, Thomas (2009) Politics in America, $8^{\text {th }}$ Edition, Longman Inc

Easterly, William and Levine, Ross (1997) "Africa's Growth Tragedy: Policies and Ethnic Divisions", Quarterly Journal of Economics 112(November):1203-50

Elkins, David J and Simeon, Richards E. B (1975) "A Cause in Search of Its Effect, or What Does Political Culture Explain?” In Crothers, Lane and Lockhart, Charles, (2000) Culture and Politics: A Reader, St Martin Press, New York NY, USA

Englebert, Pierre (2000) State Legitimacy and Development in Africa, Boulder, London: Lynne Reinner Publishers.

Englebert, Pierre \& James Ron (2004) "Primary Commodities and War: CongoBrazzaville's Ambivalent Resource Curse", Comparative Politics 36

Esman, Milton J. (1994) Ethnic Politics, Cornell University Press

Even-Zohar, Chaim (2007) From Mine to Mistress - Corporate Strategies and Government Policies in the International Diamond Industry (Revised Edition), Mining Communications Ltd.

Fearon, James D. and Laitin, David D. (2003), "Ethnicity, Insurgency, and Civil War". American Political Science Review 97, 1 (Feb 2003): pp.75-90

Fjelde, Hanne, (2009) 'Buying Peace? Oil Wealth, Corruption and Civil War, 1985-99", Journal of Peace Research 46(2): 199-218

Gibb, Richard (2006) "The New Southern African Customs Union Agreement: Dependence with Democracy"; Journal of Southern African Studies, Vol. 32, No. 3 (Sep., 2006), pp. 583-603 Taylor \& Francis, Ltd.

Gillett, Simon (1973) The Survival of Chieftaincy in Botswana", African Affairs, Vol. 72, No. 287 (Apr., 1973), pp. 179-185 
Godwin, Paul H. B (2004) “China as Regional Hegemon?” in Jim Rolfe (ed.), The AsiaPacific Region in Transition, Asia-Pacific Center for Security Studies, Honolulu, $\mathrm{HI}$

Good, Kenneth (1992) "Interpreting the Exceptionality of Botswana", Journal of Modern African Studies, (30-1) 69-95, Cambridge University Press

Gören, Erkan (2013) "How Ethnic Diversity Affects Economic Development," ZenTra Working Papers in Transnational Studies 14, ZenTra - Center for Transnational Studies.

Gowers, Andrew (1985) "Devastating Chronicle of Mismanagement." Financial Times London, England

Gylfason (2001) "Natural Resources and Economic Growth: What Is the Connection?" CESifo Working Paper, CESifo Group, Munich.

Habyarimana, James; Humphreys, Macartan; Posner, Dan and Weinstein, Jeremy (2007) "Why Does Ethnic Diversity Undermine Public Goods Provision? An Experimental Approach." American Political Science Review 101.04 (2007): $709-725$.

Hall, J.A. (ed.) 1986, States in History, Blackwell, Oxford

Hillbom, Ellen (2008) Diamonds or Development? A Structural Assessment of Botswana's Forty Years of Success, Sweden: Department of Economic History, Lund University

Horowitz, Donald L. (1985) Ethnic Groups in Conflict, Berkeley: University of California Press

Hutchinson, John, and Smith, Anthony D. eds (1996) "Introduction". In Ethnicity, pp. 114. Oxford and New York: Oxford University Press.

Iimi Atsushi, (2006) Did Botswana Escape from the Resource Curse? IMF Working Paper WP/06/138, International Monetary Fund

Inglehart, Ronald and Welzel, Christian (2005) Modernization Cultural Change and Democracy, New York: Cambridge University Press

Inoguchi, Takashi (2006) Political Cultures in Asia and Europe, Routledge Taylor and Francis Group, London and New York 
Keene, Thomas P. (2001) "Stopping the Spread of AIDS among Women in Sub-Saharan Africa, What Works and what does not: A Comparative Study of Uganda and Botswana"; Virginia Polytechnic Institute and State University, Blacksburg, VA

Kempton, D. and Du Preez, R. L. (1997) "Namibian-De Beers State-Firm Relations: Cooperation and Conflict," Journal of Southern African Studies, December 1997, Vol. 23 Issue 4.

Klare Michael T (2001) “The New Geography of Conflict”, Foreign Affairs Volume 80 No.3 49- 61 May/June 2001

Kohli, Atul (2004) State-Directed Development: Political Power and Industrialization in the Global Periphery, Cambridge University Press, UK

Kretschmer, Tobias (1998) "De Beers and Beyond: The History of the International Diamond Cartel" London, England: London Business School

Lapidus, Ira Marvin (2002) Islam in West Africa: A History of Islamic Societies, Cambridge University Press, United Kingdom

La Porta, Rafael; Lopez-de-Silanes, Florencio; Shleifer, Andrei and Vishny, Robert (1999) “The Quality of Government" Journal of Law, Economics, and Organization, 1999, 15 (1), pp. 222-79

La Porta, R., Lopez-de Silanes, F., Shleifer, A., (1998). “Law and Finance," Journal of Political Economy 106 (6), 1113-55.

Lee, Lloyd L. (2007) The Future of Navajo Nationalism, Wicazo Sa Review, Volume 22, Number 1, Spring 2007, pp. 53-68

Leonar, H. Jeffrey (1980) "Multinational Corporations and Politics in Developing Countries” World Politics, Vol. 32, No. 3 (April 1980), pp 454-483

Leonard, David. K and Strauss, Scott (2003) Africa's Stalled Development: International Causes and Cures, Boulder, London: Lynne Reinner Publishers

Lewis, Stephen R (2006) "Explaining Botswana's Success" in Harrison, Lawrence and Berger, Peter (eds) (2006) Developing Cultures: Case Studies, Routledge Taylor and Francis Group, NY and Oxon

Lipset, Seymour Martin (1983) Political Man: The Social Bases of Politics (2nd edition) Heinemann, London 
Lipset, Seymour Martin 1959. "Some Social Requisites of Democracy: Economic Development and Political Legitimacy". American Political Science Review 53 (March): 69-105

Lopus, Jane S (2003) "Capstone: Exemplary Lessons for High School Economics", New York: National Council on Economic Education. (Contributing Author)

Luong-Jones, Pauline (2002) Institutional Change and Political Continuity in Post-Soviet Central Asia: Power, Perceptions and Pacts, Cambridge University Press, United Kingdom

Masire, K., \& Lewis, Stephen, R. (2006) Very Brave or Very Foolish? Memoirs of an African Democrat. Gaborone, Botswana: Macmillan Botswana.

Maudeni, Zibani. (2004) "Mutual criticism and state: society interaction in Botswana" in Journal of Modern African Studies, Volume 42, number 4, pp. 619-636

Middleton John (ed in chief) 1997. Africa South of the Sahara: Volume 3, NY, USA: Charles Scribner's Sons

Middleton, John (ed) (1997) Encyclopedia of Africa South of the Sahara, Gale Cengage

Moene, Karl and Torvik, Ragnar (2006) Institutions and the Resource Curse, The Economic Journal, Royal Economic Society, Oxford, UK

Molutsi, Patrick (2004) "Botswana: The Path to Democracy and Development." In E. Gyimah- Boadi, ed., Democratic Reform in Africa: The Quality of Progress. Boulder and London: Lynne Rienner Publishers.

Montalvo Reynol-Querol (2005) "Ethnic Polarization, Potential Conflict and Civil Wars" Journal of Development Economics 76 (2005) 293- 323 Barcelona, Spain: The World Bank

Morton, Fred; Ramsay, Jeff; Mgadla, Themba, Part (2008), Historical Dictionary of Botswana. African Historical Dictionaries (4th ed.). Metuchen, New Jersey: Scarecrow Press

Nyati-Ramahobo, L. (1991) "Language Planning and Education Policy in Botswana. PhD Thesis", Dissertations Abstract International DAO 64793 Philadelphia, PA: University of Pennsylvania

Ogundiya, Illufoye, Sarafa (2009) The Cycle of Legitimacy Crisis in Nigeria: A Theoretical Exploration, J Soc Sci, 20(2): 129-142 
Olufemi, Vaughan (2003) Chiefs Power and Social Change: Chiefship and Modern Politics, Africa World Press, Trenton, NJ

Omeltchenko, Tanya and Olick, Jeffrey (2007) "Political Culture" in Hedblad, Alan ed. (2007) International Encyclopedia of the Social Sciences, 2nd Edition, Thomson/Gale Publishers

Ostheimer, Andrea (2000) Aid agencies: Providers or essential resources?'[in Cillier and Dietrich (eds.) (2000) Angola's War Economy: the Role of Oil and Diamonds, ISS Publications, Pretoria]

Ottaway, Marina (1999) "Ethnic Politics in Africa: Change and Continuity" In State, Conflict and Democracy in Africa ed R. Joseph, Boulder, CO; Lynne Reiner

Parson, Jack (1977) "Political Culture in Rural Botswana: A Survey Result" The Journal of Modern African Studies/Volume 15/Issue 05 pp 639-650

Parsons, Neil (1985) "The Evolution of Modern Botswana: Historical Revisions", in: Picard, Louis A. (ed.), The Evolution of Modern Botswana. London: Rex Collings, pp. 26-39. Arthur 1996

Paulker, Guy J. (1976) "Prospects for Regional Hegemony in Southeast Asia”, Statement Presented to the Subcommittee on Future Foreign Policy research and Development of the House International Relations Committee

Poynter, Thomas A. (1985) Multinational Enterprises and Government Intervention [as cited in Steinbockova, Martina (2007) "Multinational Corporations and Nation States: Partners, Adversaries or Autonomous Actors" Masaryk University in Brno]

Pulsipher, Lydia Mihelic and Pulsipher, Alex (2008) World Regional Geography: Global Patterns, Local Lives (Fourth_Edition) W. H Freeman and Company, New York, NY

Pye, LW and Verba, S (1965) Political Culture and Political Development Princeton University Press

Prys, Miriam (2008) "Developing a Contextually Relevant Concept of Regional Hegemony: The Case of South Africa, Zimbabwe and Quiet Diplomacy" Hamburg, Germany: GIGA Working Paper Series, Working Paper 77

Rabushka Alvin and. Shepsle, Kenneth A (1972) Politics in Plural Societies: A Theory of Instability, Columbus, Ohio: Charles E. Merrill Publishing Company 
Ratcliff, Donald (1994) Analytic Induction as a Qualitative Research Method of Analysis, The University of Georgia

Reteng (2008) “Alternative Report Submitted to the Human Rights Council”, Gaborone, Botswana: Reteng: The Multicultural Coalition of Botswana

Robinson, James Torvik, Ragnar and Verdier, Thierry (2006) Political Foundations of the Resource Curse; Harvard University, Cambridge MA

Rosenbaum, Walter A. (1975) Political Culture, New York: Praeger

Ross, Michael (1999) "The Political Economy of the Resource Curse", World Politics 51

Ross, Michael (2002) "Natural Resource and Civil War: An Overview with Some Policy Options", UCLA Department of Political Science, CA

Ross, Michael (2004) "How Do Natural Resources Influence Civil War? Evidence from Thirteen Cases", International Organization, The IO Foundation

Ross, Michael L (2004) "What Do We Know about Natural Resources and Civil War?" Journal of Peace Research May 2004 vol. 41 no. 3 337-356

Sachs, Jeffrey D., Warner, Andrew M. (1995). "Natural resource abundance and economic growth". NBER Working Paper 5398

Samatar, Abdi (1997) "Leadership and Ethnicity in the Making of African State Models: Botswana versus Somalia", Third World Quarterly, Taylor \& Francis, Ltd

Samatar, Abdi (1999) An African Miracle: State and Class Leadership and Colonial Legacy in Botswana Development, Heinemann, Portsmouth, $\mathrm{NH}$

Sarraf, Maria and Jiwanji, Moortaza (2001) "Beating the Resource Curse: The Case of Botswana", Environment Department Papers 24753, The World Bank

Schapera, (Ian 1953) The Tswana: Ethnographic Survey of Africa, Southern Africa Volume 2, Part III London, England: International African Institute

Schapera, Ian (1965) Forde, Daryll (ed) Ethnographic Survey of Africa: Southern Africa Part III- The Tswana, International African Institute, London

Seidler, Valentin (2010), "Why did Botswana end up with Good Institutions: The Role of Culture and Colonial Rule", Working Paper, Vienna University for Economics 
Seidler, Valentin (2011) "Colonial Legacy and Institutional Development: The Cases of Botswana and Nigeria". Doctoral Thesis, WU Vienna University of Economics and Business.

Shaxson, Nicholas (2005) "New approaches to volatility: dealing with the resource

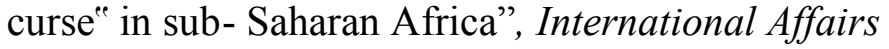

Sil, Rudra and Chen, Cheng (2004) State Legitimacy and the (In) significance of Democracy in Post-Communist Russia, Europe-Asia Studies Vol. 56, No. 3, May 2004, 347-368, Taylor and Francis Group

Smelser and Baltes, eds (2001) Analytic Induction in International Encyclopedia of the Social and Behavioral Sciences

Spiro, Melford E. (1986) "Cultural Relativism and the Future of Anthropology”, Cultural Anthropology: Vol. 1, No. 3, 259-286.

Steinbockova, Martina (2007) "Multinational Corporations and Nation States: Partners, Adversaries or Autonomous Actors" Masaryk University in Brno

Tlou, T. (1972) A Political History of Northwestern Botswana to 1906. Ph.D. diss., Department of History, University of Wisconsin

Tlou, Patrick and Campbell, Alec (1984) History of Botswana, Macmillan, Gaborone, Botswana

Transparency International (2006) "Press Release: Plundering Politicians and Bribing Multinationals Undermine Economic Development” Transparency International

Tsie, Balefi (1996) The Political Context of Botswana's Development Performance, Journal of Southern African Studies, Taylor \& Francis, Ltd.

Van Walraven, K. (1999) Dreams of Power: The role of the Organization of African Unity in the Politics of Africa 1963-1993, England: Ashgate Publishing Limited

Vernon, Raymond (1971) Sovereignty at Bay: The Multinational Spread of U.S. Enterprises New York: Basic Books

Wallis, John Joseph and North, Douglas, C (2011) Governments and States: Organizations, Politics and Social Dynamics, paper presented at the Mercatus Center

Warren, Mar E. (2004) Democracy and the State, University of British Columbia, Vancouver, Canada 
Weber, Max. (1978) "The Types of Legitimate Domination" in Economy and Society, edited by Roth, Guenther and Wittich, Claus. Berkeley: University of California Press

Weinthal, Erika and Luong, Pauline Jones (2006) Combating the Resource Curse: An Alternative to Managing Mineral Wealth, Cambridge University Press

Yates, Douglas. A (1996) The Rentier State in Africa: Oil Rent Dependency and Neocolonialism in the Republic of Gabon, Africa World Press, Trenton, New Jersey

Yin, R. (1994). Case Study Research: Design and Methods (2nd ed.). Sage Publishing, Beverly Hills, CA

Zhang, Nan (2007) "Neo-patrimonialistic Politics, Resource Curse and The Political Economy of Botswana", University of Berkeley, California 


\section{Web References}

Africa Economic Outlook (2012) "Botswana" Web page:

http://www.africaneconomicoutlook.org/en/countries/southern-africa/botswana/

Bhattacharya, Aveek (2012) Should Votes be for Sale? Web page:

http://socialproblemsarelikemaths.blogspot.com/

Gallagher, Michael (2002) The Birth and Death of Apartheid:

http://news.bbc.co.uk/2/hi/africa/575204.stm

Kaplan, Barry B (2002) Forever Diamonds: A powerful company, a catchy slogan, and how they forever changed the way we value diamonds. Web page:

http://www.gemnation.com/base?processor=getPage\&pageName=forever diamo $\underline{\text { nds_1 } 1}$

Joshua Project Botswana- People Groups:

http://joshuaproject.net/countries.php? $\operatorname{rog} 3=\mathrm{BC}$

Murdock, Heather (2012) "Untangling ethnic and religious violence in Nigeria's "Middle Belt"' Accessed September 13, 2012:

http://www.globalpost.com/dispatch/news/regions/africa/nigeria/120515/n igeria-jos-sectarian-violence

National Open University of Nigeria (2009) "Introduction to African Politics" National Open University of Nigeria, Lagos, Nigeria

Accessed July 22, 2012

http://www.nou.edu.ng/noun/NOUN OCL/pdf/pdf2/POL\%20122.pdf

Oneil, Dennis (2013) Nature of Ethnicity: http://anthro.palomar.edu/ethnicity/ethnic 2.htm

UNDP (2005) The Human Development Report for Serbia 2005:

http://hdr.undp.org/en/reports/nationalreports/europethecis/serbia/name,3304,en.h tml

Parsons, Neil (1999) Botswana History Pages, http://ubh.tripod.com/bw/bhp6.htm

Wood, Ethel (2012) "The Sources of Public Authority and Political Power" Accessed September 12, 2012:

http://phs.prs.k12.nj.us/ewood/sources.html

Skinner EP (1970) "African Political Cultures and the Problems of Government" African Studies Quarterly. Accessed July $25^{\text {th }}, 2012$

http://www.africa.ufl.edu/asq/v2/v2i3a3.htm 
Appendix I: Conflict in Africa by State Borders

\section{Conflicts in Africa by State Borders}

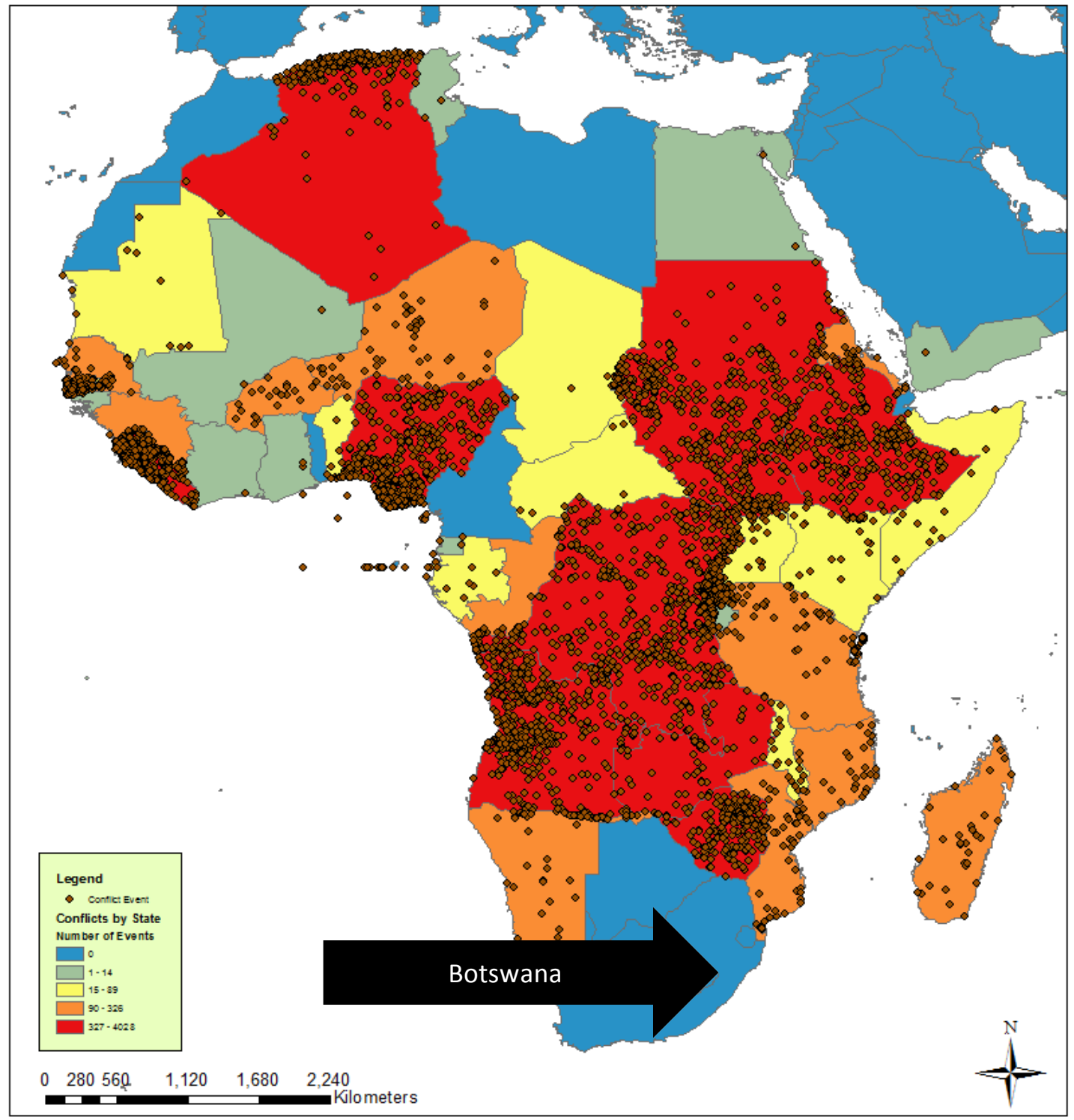




\section{Appendix II: African Democracy Ratings}

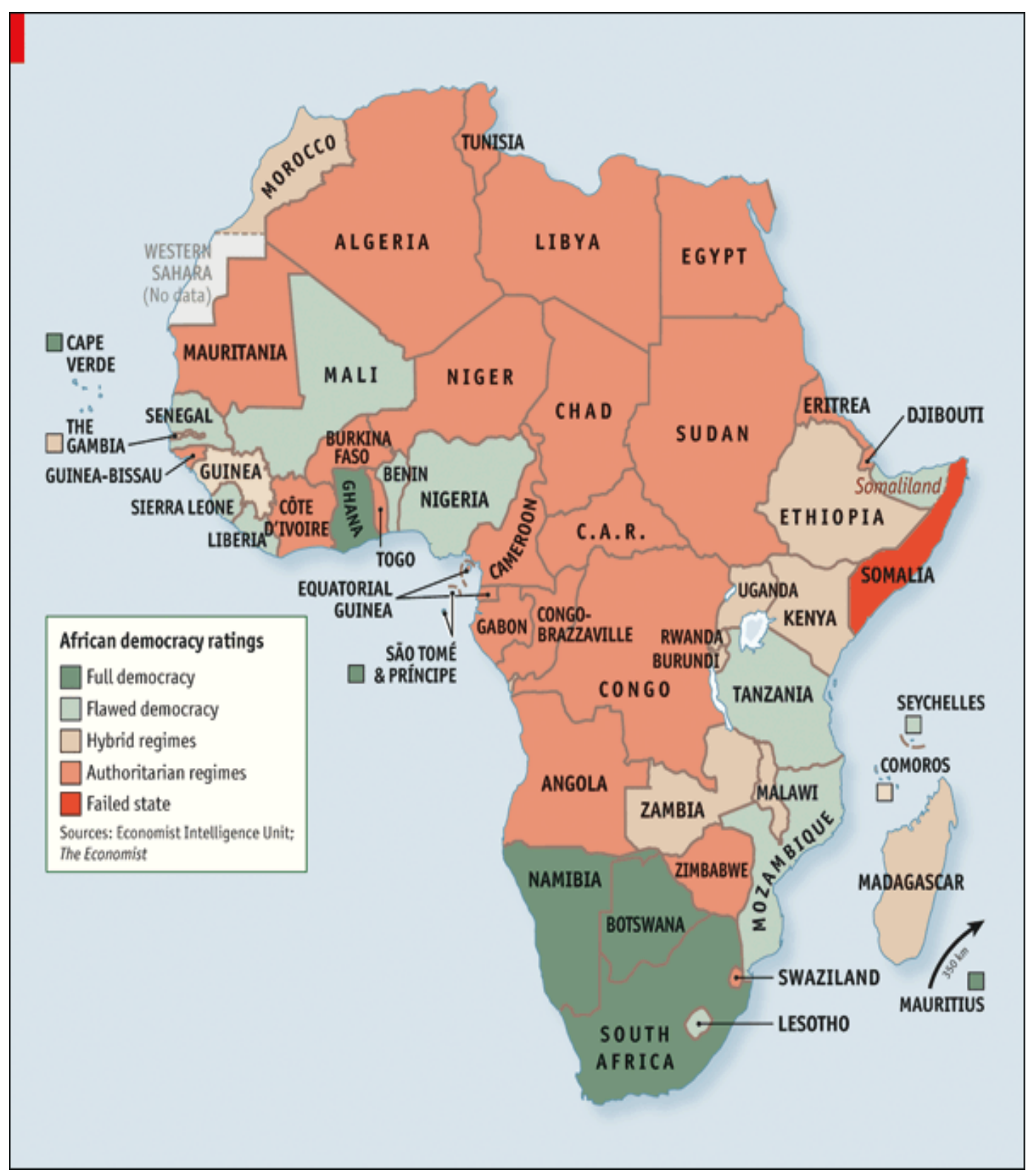




\section{Appendix III}

\begin{tabular}{|c|c|}
\hline \multicolumn{2}{|c|}{ Bertelsmann Transformation Index: Indicators of Institutional Quality } \\
\hline Indicator & Description \\
\hline \multicolumn{2}{|l|}{ Status of Democratic Development } \\
\hline Stateness & $\begin{array}{l}\text { There is clarity about the nation's existence as a state with adequately established and } \\
\text { differentiated power structures. }\end{array}$ \\
\hline Monopoly on the use of force & $\begin{array}{l}\text { To what extent does the state's monopoly on the use of force cover the entire territory of } \\
\text { the country? }\end{array}$ \\
\hline State identity & $\begin{array}{l}\text { To what extent do all relevant groups in society agree about citizenship and accept the } \\
\text { nation-state as legitimate? }\end{array}$ \\
\hline $\begin{array}{l}\text { No interference of religious } \\
\text { dogmas }\end{array}$ & $\begin{array}{l}\text { To what extent are legal order and political institutions defined without interference by } \\
\text { religious dogmas? }\end{array}$ \\
\hline Basic administration & To what extent do basic administrative structures exist? \\
\hline Political Participation & The populace decides who rules, and it has other political freedoms. \\
\hline Free and fair elections & To what extent are political representatives determined by general, free and fair elections? \\
\hline Effective power to govern & $\begin{array}{l}\text { To what extent do democratically elected political representatives have the effective power } \\
\text { to govern, or to what extent are there veto powers and political enclaves? }\end{array}$ \\
\hline Association / assembly rights & $\begin{array}{l}\text { To what extent can individuals form and join independent political or civic groups? To } \\
\text { what extent can these groups operate and assemble freely? }\end{array}$ \\
\hline Freedom of expression & To what extent can citizens, organizations and the mass media express opinions freely? \\
\hline Rule of Law & State powers check and balance one another and ensure civil rights. \\
\hline Separation of powers & To what extent is there a working separation of powers (checks and balances)? \\
\hline Independent judiciary & To what extent does an independent judiciary exist? \\
\hline Prosecution of office abuse & To what extent are public officeholders who abuse their positions prosecuted or penalized? \\
\hline Civil rights & $\begin{array}{l}\text { To what extent are civil rights guaranteed and protected, and to what extent can citizens } \\
\text { seek redress for violations of these rights? }\end{array}$ \\
\hline $\begin{array}{l}\text { Stability of Democratic } \\
\text { Institutions }\end{array}$ & Democratic institutions are capable of performing, and they are adequately accepted. \\
\hline $\begin{array}{l}\text { Performance of democratic } \\
\text { institutions }\end{array}$ & Are democratic institutions capable of performing? \\
\hline $\begin{array}{l}\text { Commitment to democratic } \\
\text { institutions }\end{array}$ & To what extent are democratic institutions accepted as legitimate by the relevant actors? \\
\hline Political and Social Integration & $\begin{array}{l}\text { Stable patterns of representation exist for mediating between society and the state; there is } \\
\text { also a consolidated civic culture. }\end{array}$ \\
\hline Party system & $\begin{array}{l}\text { To what extent is there a stable and socially rooted party system able to articulate and } \\
\text { aggregate societal interests? }\end{array}$ \\
\hline Interest groups & $\begin{array}{l}\text { To what extent is there a network of cooperative associations or interest groups to mediate } \\
\text { between society and the political system? }\end{array}$ \\
\hline Consent to democratic norms & How strong is the citizens' approval of democratic norms and procedures? \\
\hline Associational activities & $\begin{array}{l}\text { To what extent have social self-organization and the construction of social capital } \\
\text { advanced? }\end{array}$ \\
\hline \multicolumn{2}{|l|}{ Status of Market Development } \\
\hline Socioeconomic Level & $\begin{array}{l}\text { In principle, the country's level of development permits adequate freedom of choice for all } \\
\text { citizens. }\end{array}$ \\
\hline Socioeconomic barriers & $\begin{array}{l}\text { To what extent are significant parts of the population fundamentally excluded from society } \\
\text { due to poverty and inequality? }\end{array}$ \\
\hline Market Organization & There are clear rules for stable, market-based competition. \\
\hline Market-based competition & To what level have the fundamentals of market-based competition developed? \\
\hline Anti-monopoly policy & $\begin{array}{l}\text { To what extent do safeguards exist to prevent the development of economic monopolies } \\
\text { and cartels, and to what extent are they enforced? }\end{array}$ \\
\hline Liberalization of foreign trade & To what extent has foreign trade been liberalized? \\
\hline Banking system & $\begin{array}{l}\text { To what extent have a solid banking system and a functioning capital market been } \\
\text { established? }\end{array}$ \\
\hline Currency and Price Stability & $\begin{array}{l}\text { There are institutional or political precautions to control inflation sustainably, together } \\
\text { with an appropriate monetary policy and fiscal policy. }\end{array}$ \\
\hline
\end{tabular}




\begin{tabular}{|c|c|}
\hline Anti-inflation / forex policy & $\begin{array}{l}\text { To what extent do government and central bank pursue a consistent inflation policy and an } \\
\text { appropriate foreign exchange policy? }\end{array}$ \\
\hline Macrostability & $\begin{array}{l}\text { To what extent do the government's fiscal and debt policies support macroeconomic } \\
\text { stability? }\end{array}$ \\
\hline Private Property & There are adequate conditions to support a functional private sector. \\
\hline Property rights & $\begin{array}{l}\text { To what extent do government authorities ensure well-defined rights of private property } \\
\text { and regulate the acquisition, benefits, use and sale of property? }\end{array}$ \\
\hline Private enterprise & $\begin{array}{l}\text { To what extent are private companies permitted and protected? Are privatization processes } \\
\text { conducted in a manner consistent with market principles? }\end{array}$ \\
\hline Welfare Regime & There are viable arrangements to compensate for social risks. \\
\hline Social safety nets & To what extent do social safety nets provide compensation for social risks? \\
\hline Equal opportunity & To what extent does equality of opportunity exist? \\
\hline Economic Performance & The economy's performance points to solid development. \\
\hline Output strength & How does the economy, as measured in quantitative indicators, perform? \\
\hline Sustainability & Economic growth is balanced, environmentally sustainable and future-oriented. \\
\hline Environmental policy & $\begin{array}{l}\text { To what extent are environmental concerns effectively taken into account in both macro } \\
\text { and microeconomic terms? }\end{array}$ \\
\hline Education policy / R\&D & $\begin{array}{l}\text { To what extent are there solid institutions for basic, secondary and tertiary education, as } \\
\text { well as for research and development? }\end{array}$ \\
\hline \multicolumn{2}{|l|}{ Transformation Management } \\
\hline Level of Difficulty & Assesses the structural conditions that influence the scope of political action. \\
\hline Structural constraints & $\begin{array}{l}\text { To what extent do structural difficulties constrain the political leadership's governance } \\
\text { capacity? }\end{array}$ \\
\hline Civil society traditions & To what extent are there traditions of civil society? \\
\hline Conflict intensity & How serious are social, ethnic and religious conflicts? \\
\hline GNI p.c. rescaled & Per capita GNI PPP \\
\hline UN Educ. Index rescaled & UN Education Index as a measure of the educational level \\
\hline Stateness \& Rule of law & Stateness and Rule of Law (average of BTI criteria values) \\
\hline Steering Capability & The government manages reforms effectively and can achieve its policy priorities. \\
\hline Prioritization & To what extent does the government set and maintain strategic priorities? \\
\hline Implementation & How effective is the government in implementing its own policies? \\
\hline Policy learning & How innovative and flexible is the government? \\
\hline Resource Efficiency & The government makes optimum use of available resources. \\
\hline Efficient use of assets & $\begin{array}{l}\text { To what extent does the government make efficient use of available human, financial and } \\
\text { organizational resources? }\end{array}$ \\
\hline Policy coordination & $\begin{array}{l}\text { To what extent can the government coordinate conflicting objectives into a coherent } \\
\text { policy? }\end{array}$ \\
\hline Anti-corruption policy & To what extent does the government successfully contain corruption? \\
\hline Consensus-Building & $\begin{array}{l}\text { The political leadership establishes a broad consensus on reform with other actors in } \\
\text { society without sacrificing its reform goals. }\end{array}$ \\
\hline Consensus on goals & $\begin{array}{l}\text { To what extent do the major political actors agree on democracy and a market economy as } \\
\text { strategic, long-term goals? }\end{array}$ \\
\hline Anti-democratic actors & To what extent can reformers exclude or co-opt anti-democratic actors? \\
\hline Cleavage / conflict management & $\begin{array}{l}\text { The political leadership establishes a broad consensus on reform with other actors in } \\
\text { society without sacrificing its reform goals. }\end{array}$ \\
\hline Civil society participation & $\begin{array}{l}\text { To what extent does the political leadership enable the participation of civil society in the } \\
\text { political process? }\end{array}$ \\
\hline Reconciliation & $\begin{array}{l}\text { To what extent can the political leadership bring about reconciliation between the victims } \\
\text { and perpetrators of past injustices? }\end{array}$ \\
\hline International Cooperation & $\begin{array}{l}\text { The political leadership is willing and able to cooperate with external supporters and } \\
\text { organizations. }\end{array}$ \\
\hline Effective use of support & $\begin{array}{l}\text { To what extent does the political leadership use the support of international partners to } \\
\text { implement a long-term strategy of development? }\end{array}$ \\
\hline Credibility & $\begin{array}{l}\text { To what extent does the government act as a credible and reliable partner in its relations } \\
\text { with the international community? }\end{array}$ \\
\hline Regional cooperation & $\begin{array}{l}\text { To what extent is the political leadership willing and able to cooperate with neighboring } \\
\text { countries? }\end{array}$ \\
\hline
\end{tabular}




\section{Appendix IV}

Political Institutional Quality Indicators (2010)

(Angola, Botswana, Dem. Congo, and Nigeria)

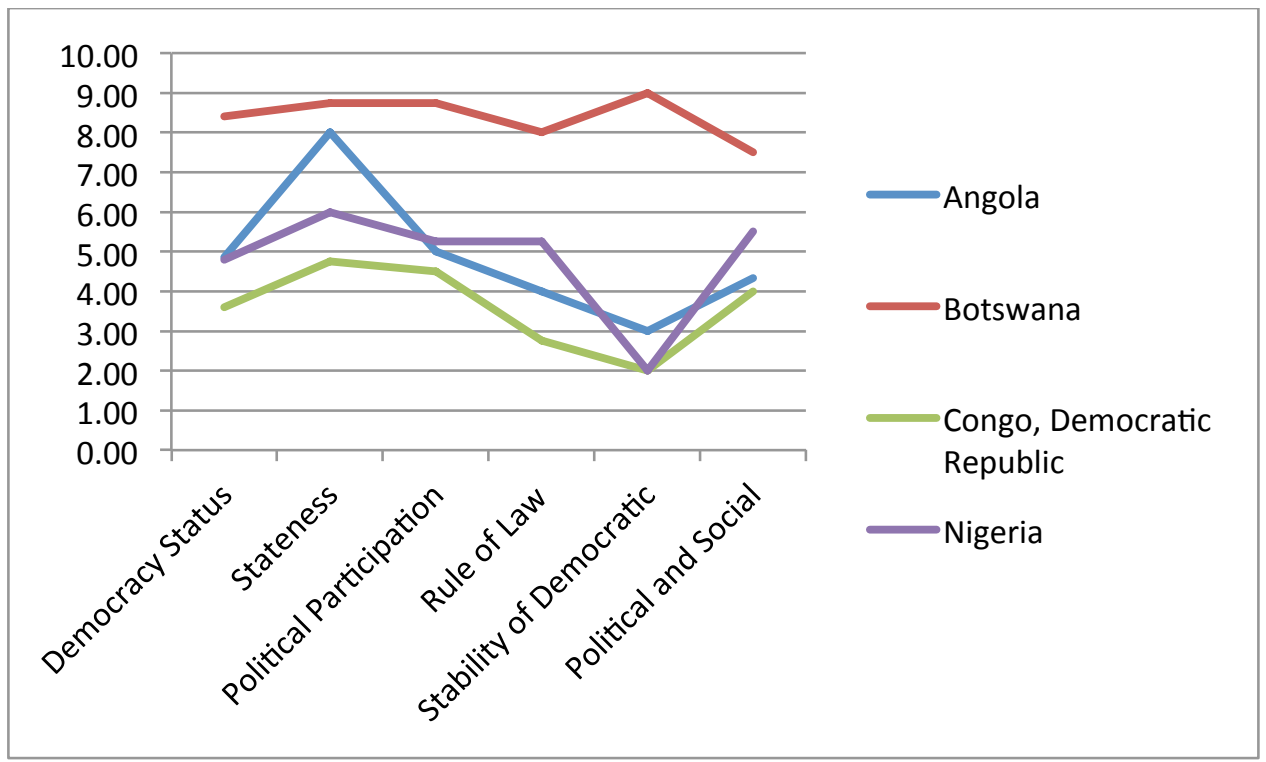

Source: Bertelsemann Transformation Index (2010) 


\section{Appendix V}

Economic Institutions Status:

Angola, Botswana, Democratic Republic of Congo and Nigeria (2010)

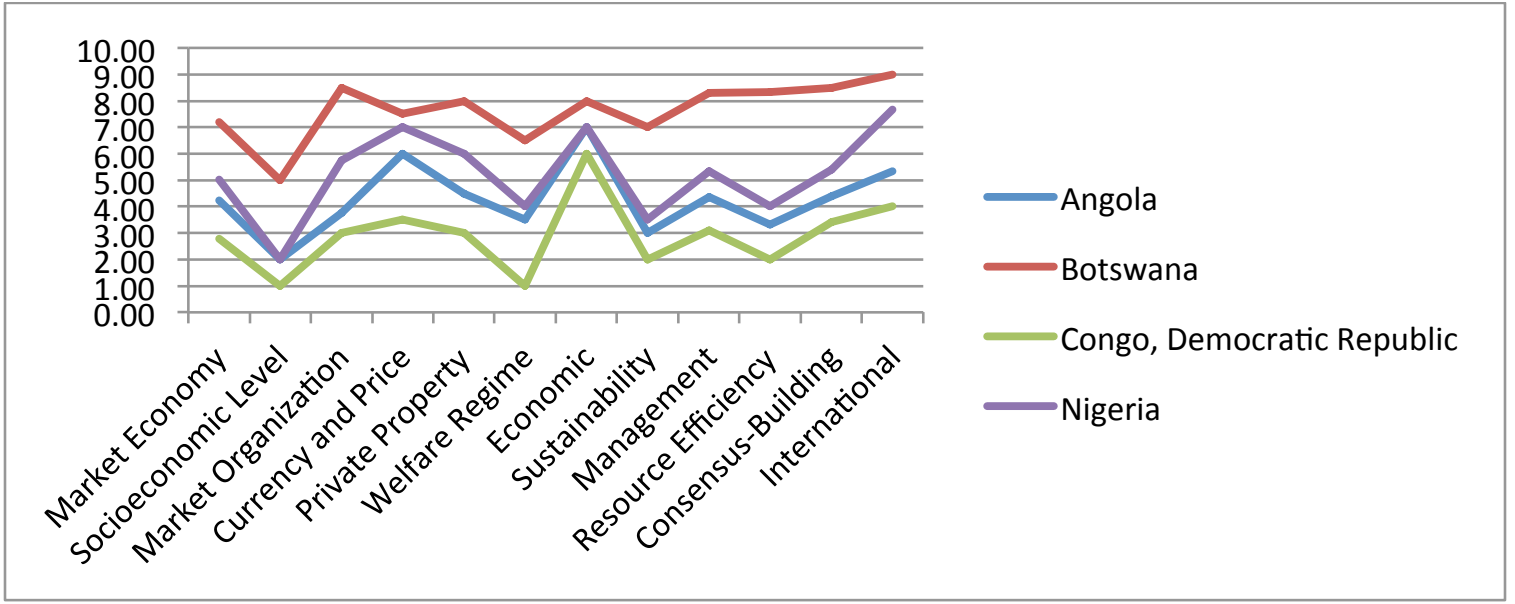

Source: Bertelsemann Transformation Index (2010) 


\section{Appendix VI:}

GDP per Capita Trend: 1965 to 2007

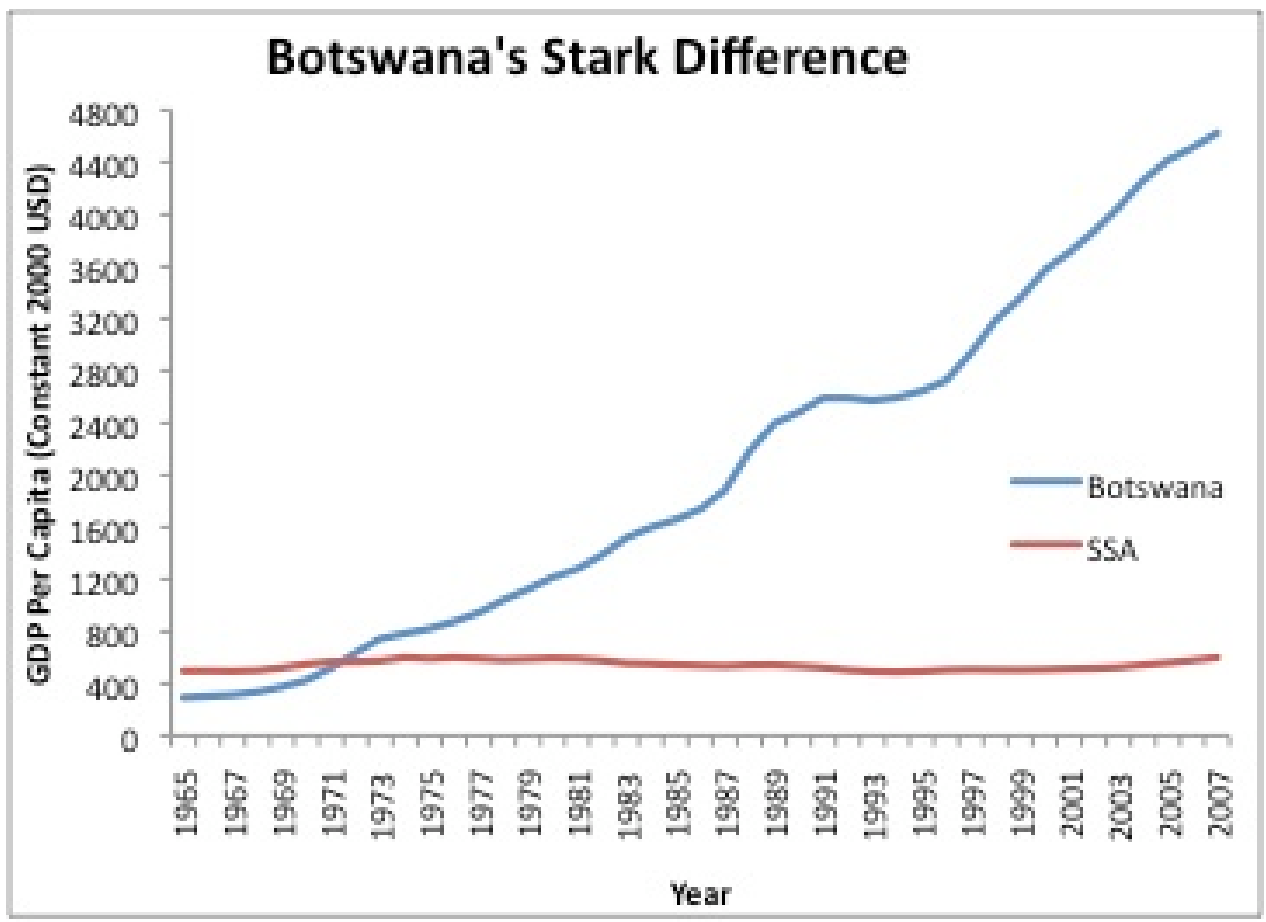


VITA

ANGELA GAPA

Born: Harare, Zimbabwe

2002-2006

Bachelor of Science (Hons)

Environmental Science and Health

National University of Science and Technology

Bulawayo, Zimbabwe

$2007-2010$

Master of Arts

International Studies

Florida International University

Miami, FL

2010

Graduate Certificate

National Security

Florida International University

Miami, FL

2013

Doctoral Candidate

International Relations

Florida International University

Miami, FL

\section{PUBLICATIONS AND PRESENTATIONS}

Gapa, A (2012) "Legitimacy and Political Culture in Botswana's Escape of the Resource Curse" Paper Presented for the International Studies Convention, April 1st to 4th, San Diego, CA

Gapa, A. (2010) "Botswana's Escape from the Resource Curse: The Case of State Legitimacy" Paper presented for the African Studies Association, November 1720, San Francisco, CA

Gapa, A. (2010) "International Resource Regimes and the Prospects of Peace and Development in Sub-Saharan Africa" Paper presented for the International Studies Association October 20-21, St Petersburg, FL

Gapa, A. (2007) "Corruption: Tracing the Effects, Charting a Sustainable Future" pages 81-92, World Bank, Bled Slovenia 


\section{TEACHING EXPERIENCE}

2010

Adjunct Professor,

Florida International University

Department of Politics and International Relations

International Relations of Sub-Saharan Africa

African Politics

Contemporary International Problems

International Organizations

Department of African \& African Diaspora Studies

China and India in Africa

$2007-2010$

Teaching Assistant

Florida International University

Department of International Relations and Geography

International Relations of Sub-Saharan Africa

Contemporary International Issues

International Relations of the US

World Regional Geography

Political Geography

\section{RESEARCH EXPERIENCE}

2010 - $2011 \quad$ Jack D. Gordon Institute for Public Policy and Citizenship Studies

ACADEMIC AWARDS

2011

Dissertation Evidence Acquisition Fellowship

FIU-University Graduate School

Graduate Assistantship

Jack D. Gordon Institute for Public Policy and Government Studies

2009

Adolpho Henriques Scholarship

2006

Vice Chancellor's Prize for Best Graduating Student in Faculty

National University of Science and Technology

2006

NUST Book Prize- For Best Graduating Student in Department

National University of Science and Technology 